UNIVERSIDADE DE SÃO PAULO

FACULDADE DE FILOSOFIA, LETRAS E CIÊNCIAS HUMANAS

ANA CAROLINA CORTEZ NORONHA

Semiótica, educação e o uso da tecnologia digital em sala de aula 
Ana Carolina Cortez Noronha

Semiótica, educação e o uso da tecnologia digital em sala de aula

versão corrigida

Tese apresentada ao Departamento de Linguística da Faculdade de Filosofia, Letras e Ciências Humanas da Universidade de São Paulo para obtenção do título de doutora em Letras.

área de concentração: Semiótica e Linguística Geral

orientadora: Profa. Dra. Diana Luz Pessoa de Barros

São Paulo 
Autorizo a reprodução total ou parcial deste trabalho, por meio convencional ou eletrônico, com a finalidade de estudo e pesquisa, desde que citada a fonte.

Catalogação na Publicação Serviço de Biblioteca e Documentação

Faculdade de Filosofia, Letras e Ciências Humanas da Universidade de São Paulo

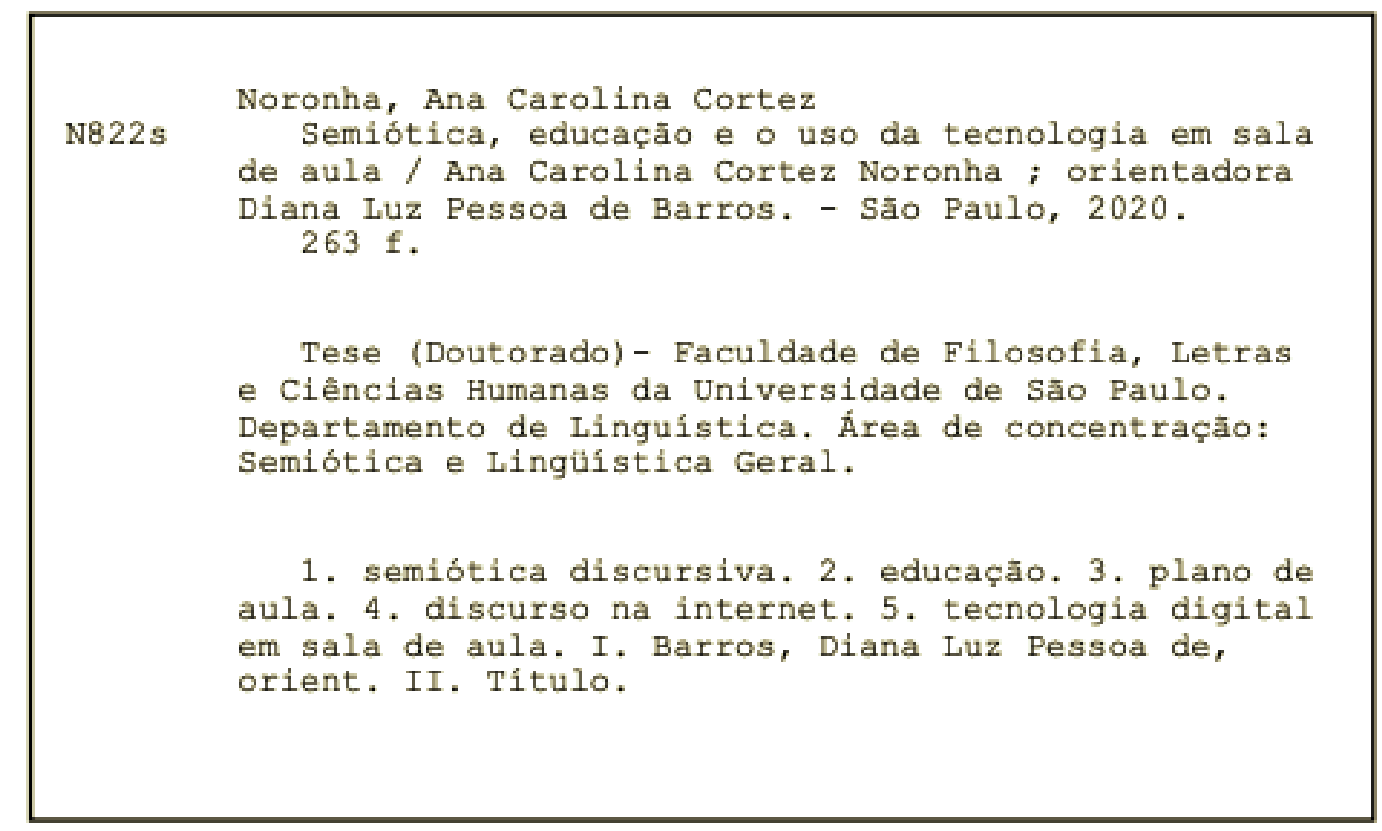




\section{TERMO DE CIÊNCIA E CONCORDÂNCIA DA ORIENTADORA}

Nome da aluna: Ana Carolina Cortez Noronha

Data da defesa: 07 / 12 / 2020

Nome da professora orientadora: Profa. Dra. Diana Luz Pessoa de Barros

Nos termos da legislação vigente, declaro estar ciente do conteúdo deste exemplar corrigido elaborado em atenção às sugestões dos membros da comissão julgadora na sessão de defesa do trabalho, manifestando-me plenamente favorável ao seu encaminhamento e publicação no Portal Digital de Teses da USP.

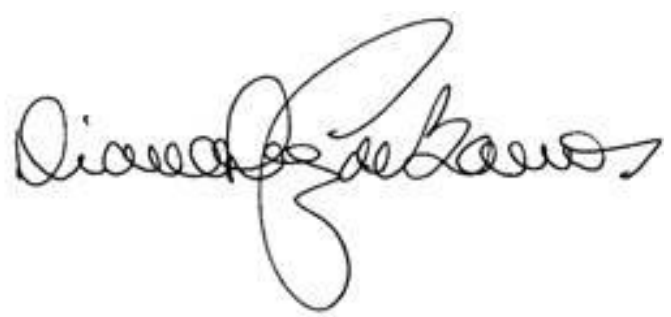

São Paulo, 17 / 12 / 2020 


\section{FOLHA DE AVALIAÇÃO}

NORONHA, Ana Carolina Cortez. Semiótica, educação e o uso da tecnologia digital em sala de aula. Tese apresentada à Faculdade de Filosofia, Letras e Ciências Humanas para obtenção do título de doutora em Letras. São Paulo, dezembro de 2020.

Data do exame: 07 de dezembro de 2020.

\section{Banca de Examinadores:}

Profa. Dra. Diana Luz Pessoa de Barros (presidente)

DL-FFLCH-USP / UPM

Prof. Dr. Ivã Carlos Lopes

DL-FFLCH-USP

Prof. Dr. Arnaldo Cortina

FCLAr-UNESP

Prof. Dr. Jean Cristtus Portela

FCLAr-UNESP 


\section{DEDICATÓRIA}

Às que vieram antes, todas elas, abrindo caminhos. 


\section{AGRADECIMENTOS}

À Universidade de São Paulo, USP, que resiste, produzindo saber. Às demais universidades e centros de produção de conhecimento deste país. A todos aqueles que, todo dia, as mantêm em funcionamento.

À Coordenação de Aperfeiçoamento de Pessoal de Nível Superior, CAPES, pela bolsa de estudos, essencial para o desenvolvimento deste projeto.

A Diana Luz Pessoa de Barros, pelo exemplo de produção do saber e pela orientação valiosíssima com que tive o privilégio de contar. A Norma Discini, pelas inquietações que desperta e inspira. A Ivã Carlos Lopes, pelas contribuições na banca de qualificação e ao longo do caminho e, principalmente, por levar adiante o projeto do GES-USP, que nos acolhe a todos que chegamos e do qual pude participar mais proximamente nos últimos anos. A Arnaldo Cortina e Jean Portela, pela presença valiosa nas bancas e ao longo desta longa história. A Waldir Beividas e Elizabeth Harkot-de-la-Taille por levarem a semiótica adiante no dia a dia da pós-graduação, pelos ensinamentos e acolhida.

Aos membros do Grupo de Estudos Semióticos da USP, GES-USP, por tudo o que com vocês aprendi. Aos linguistas e semioticistas todos. Aos que fazem pesquisa, organizam encontros, apoiam-se uns aos outros, constroem caminhos e pontes.

A todas e todos que estiveram ao meu lado em algum trecho deste percurso: vocês foram importantíssimos. Aos que permanecem: vocês são imprescindíveis.

Aos que me ensinaram, na vida e na escola, por me ajudarem a chegar aqui.

A todas e todos aqueles que, de algum modo, contribuem para fazer deste um mundo melhor e, de modo especial, meu agradecimento às professoras e aos professores, heróis anônimos do cotidiano. 


\section{EPÍGRAFE}

A educação é o ponto em que decidimos se amamos o mundo o bastante para assumirmos a responsabilidade por ele e, com tal gesto, salvá-lo da ruína que seria inevitável não fosse a renovação e a vinda dos novos e dos jovens. A educação é, também, onde decidimos se amamos nossas crianças o bastante para não expulsá-las de nosso mundo e abandoná-las a seus próprios recursos, e tampouco arrancar de suas mãos a oportunidade de empreender alguma coisa nova $e$ imprevista para nós, preparando-as em vez disso com antecedência para a tarefa de renovar um mundo comum.

Hannah Arendt (1906-75 filósofa alemã)

A língua é a roupa do pensamento.

Samuel Johnson (1709-84 poeta inglês) 


\section{RESUMO}

\section{SEMIÓTICA, EDUCAÇÃO E O USO DA TECNOLOGIA DIGITAL EM SALA DE AULA}

Esta tese propõe uma investigação sobre a organização da transmissão da cultura e da construção do conhecimento no espaço escolar, no Brasil, no início do século XXI. Para isso, toma como objeto de análise planos de aula disponibilizados online em um site do Ministério da Educação, nos quais se investiga um simulacro do fazer da sala de aula no seu planejamento. Os planos são analisados discursivamente, utilizando-se a teoria semiótica do discurso de linha greimasiana, em especial os conceitos ligados aos estudos da enunciação (BARROS, 2001; FIORIN, 2002). Também se preocupa em investigar o discurso na internet e seu uso, cada vez mais intensificado, como meio de transmissão de informações e de construção do conhecimento. Decorrem dessas análises, entre outros, as estratégias discursivas de persuasão nos planos de aula, os valores que constroem o conceito de "boa aula" e os que circulam na educação brasileira. Ainda, propõem-se modos como a semiótica, com seu ferramental de análise, pode contribuir para melhores usos da tecnologia em sala de aula como, por exemplo, por meio de seu conceito de veridicção e de contrato fiduciário. Entendendo que os processos de educação sejam ativos e estejam sempre em adaptação às novas realidades e necessidades de cada geração, reflete-se sobre as mudanças causadas pela presença cada vez mais intensa da tecnologia na sala de aula com base no pensamento de Hannah Arendt (2014), com a concepção de que cabe à educação o papel de preparar o sujeito para o novo mundo que se renova a cada geração e, ao mesmo tempo, preservar o mundo anterior existente, apresentando-o ao aprendiz.

PALAVRAS-CHAVE: semiótica discursiva; educação; plano de aula; discurso na internet; tecnologia digital em sala de aula. 


\section{ABSTRACT}

\section{SEMIOTICS, EDUCATION AND THE USE OF DIGITAL TECHNOLOGY IN THE CLASSROOM}

This thesis proposes an investigation on the organization of the transmission of culture and the construction of knowledge in the school space, in Brazil, at the beginning of the 21st century. To do so, it takes as an object of analysis lesson plans made available online on a website of the Ministry of Education, which is conceived as a simulacrum of what happens in the classroom. The plans are analyzed as a discourse, using the French semiotics theory of discourse, especially the concepts linked to the studies of enunciation (BARROS, 2001; FIORIN, 2002). It is also concerned with investigating discourse on the Internet and its increasingly intensified use as a means of transmitting information and building knowledge. These analyses result, among others, in the discoursive strategies of persuasion in lesson plans, the values that are found building the concept of "good class" and those that circulate in Brazilian education. It also proposes ways in which semiotics, with its analysis tool, can contribute to better uses of technology in the classroom, such as, for example, its concept of truth and fiduciary contract. Understanding that education processes are active and always adapting to the new realities and needs of each generation, this thesis reflects on the changes caused by the increasingly intense presence of technology in the classroom based on the thoughts of Hannah Arendt (2014), with the conception that education has the role of preparing the subject for the new world that is being renewed by each generation and, at the same time, preserving the existing previous world by presenting it to the learner.

keywords: discoursive semiotics; education; lesson plan; discourse on the internet; digital technology in the classroom 


\section{LISTA DE FIGURAS}

Figura 1 - Organização do Tutorial de criação de aula............................................................51

Figura 2 - Seção Estratégias e Recursos do tutorial Como Criar uma Aula, no Portal do Professor

Figura 3 - Seção Avaliação, no Tutorial de Como criar uma aula...........................................58

Figura 4 - Diagrama Regimes de Interação........................................................................78

Figura 5 - print de tela de busca de aulas no Portal do Professor. .......................................100

Figura 6 - print de tela de resultado para busca de aulas "melhor classificadas" no Portal do Professor em out./2015. 100

Figura 7 - print de tela de resultado para busca de aulas "melhor classificadas" no Portal do Professor em dez./2019. 101

Figura 8 - Taxonomia de Bloom e legenda em artigo de Ferraz e Belhot (2010). 104

Figura 9 - Tutorial da aula 1, plano de aula 01.

Figura 10 - retirada do plano de aula 01 mostrando os classmates. 114

Figura 11 - Cartaz 3 do plano de aula 02 120

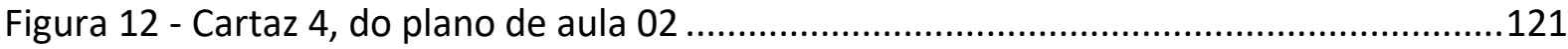

Figura 13 - Exemplo de debreagem interna, plano de aula 3. 164

\section{LISTA DE TABELAS}

Tabela 1 - subdimensões e foremas

Tabela 2 - os verbos dos objetivos de aprendizagem dos planos de aula analisados. 153

Tabela 3 - comparação entre objetivos e avaliação nos planos de aula. 


\section{SUMÁRIO}

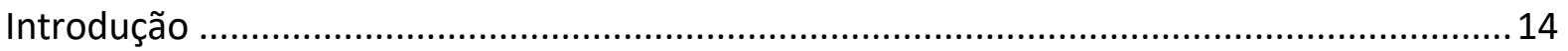

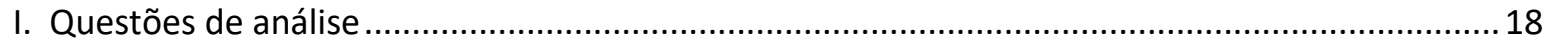

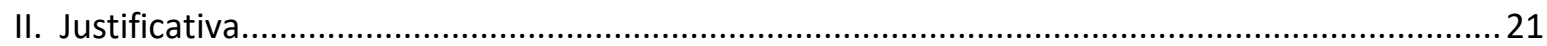

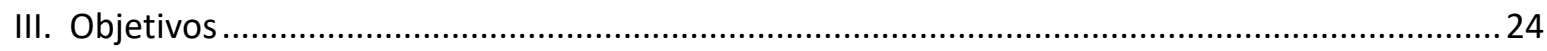

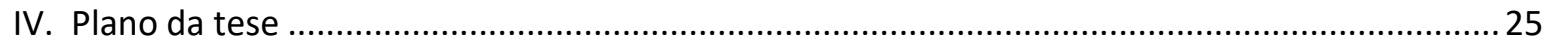

1. Percursos da educação escolar brasileira: da legislação ao plano de aula ........................27

1.10 discurso sobre a educação brasileira do final do século XX e início do XXI ..............................27

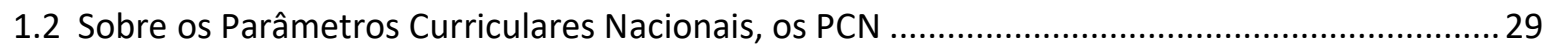

1.2.1 Os objetivos dos Parâmetros Curriculares Nacionais ........................................................... 32

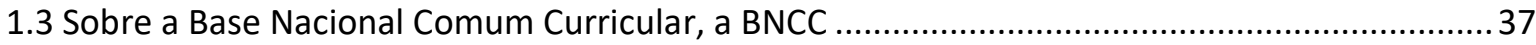

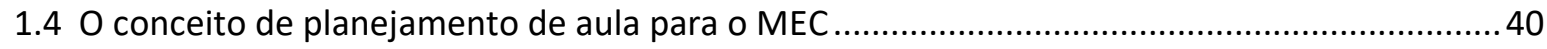

1.4.1 A edição do Jornal do Professor sobre Planejamento Escolar ............................................ 41

1.4.2 Tutorial de como criar uma aula no Portal do Professor ..................................................... 48

$1.5 \mathrm{O}$ gênero textual plano de aula disponível online ..................................................................61

2. Conceitos de análise e o plano de aula disponível online ................................................67

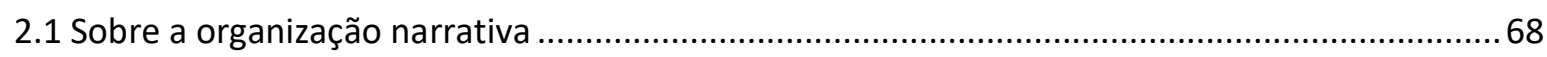

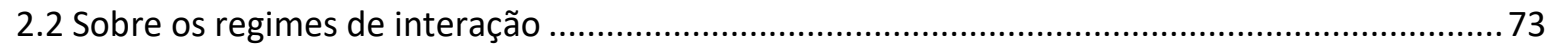

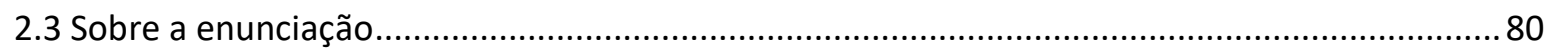

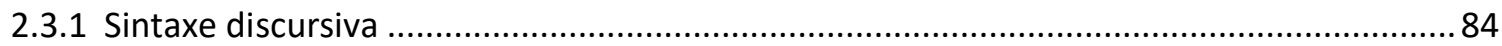

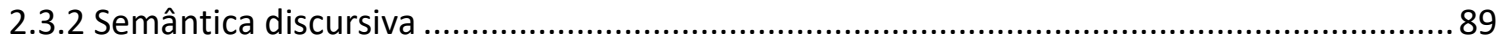

2.3.3 Relações entre enunciador e enunciatário ….....................................................................91

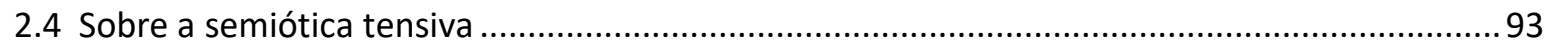

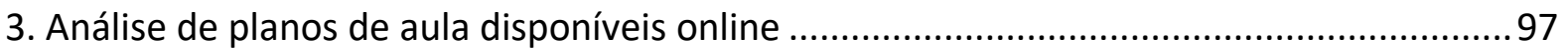

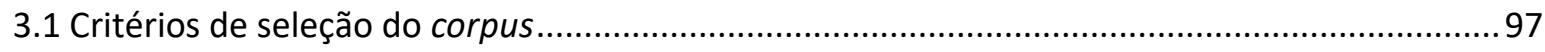

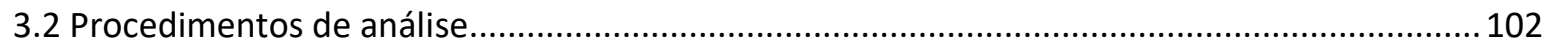


3.3 Análise do plano de aula 01 - UCA - As potencialidades do conhecimento pela navegação na Internet: uma visita ao Museu da Língua Portuguesa......................................................... 105

3.4 Análise do plano de aula 02 - Entendendo as funções da linguagem. ......................................116

3.5 Análise do plano de aula 03 - Coesão textual: o pronome na construção do texto.................123

3.6 Análise do plano de aula 04 - Publicando com Cecília Meireles.............................................. 130

3.7 Análise do plano de aula 05 - Debate Deliberativo sobre Bullying ........................................ 135

3.8 Análise do plano de aula 06 - As várias facetas de Machado de Assis .................................... 143

3.9 Análise do plano de aula 07 - Lições de língua crítica e culta................................................ 146

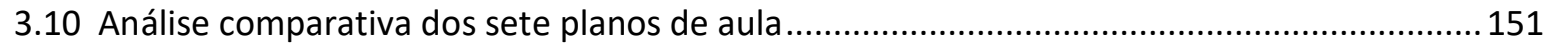

3.10.1 A seção Objetivos da aula e a seção Avaliação ............................................................. 152

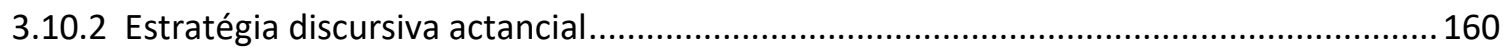

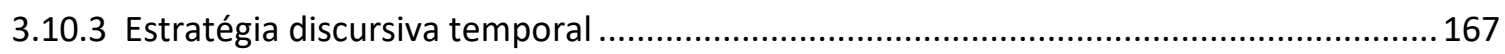

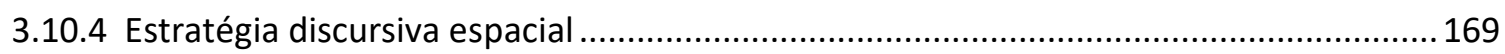

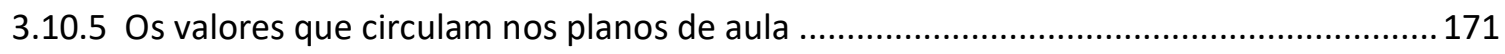

3.10.6 O ator da enunciação no plano de aula disponível online ............................................ 175

3.10.7 Regimes de interação nos planos de aula .................................................................. 181

3.10.8 Sobre o uso da tecnologia observado nos planos de aula analisados ............................. 185

4. A tecnologia digital em sala de aula: reflexões e propostas .......................................... 186

4.1 A crise na educação e no modo de pensar contemporâneo ....................................................187

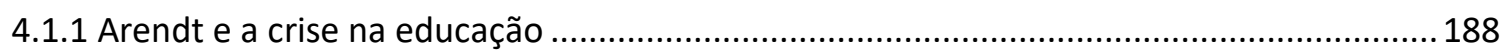

4.1.2 A crise na transmissão do saber na contemporaneidade .................................................. 191

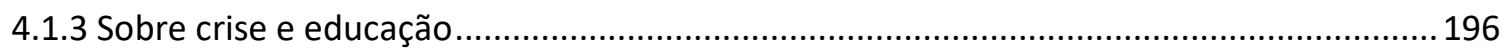

4.2 Tecnologia digital em educação …………......................................................................... 199

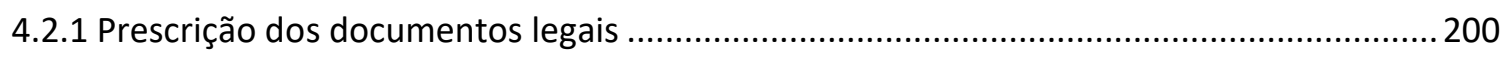

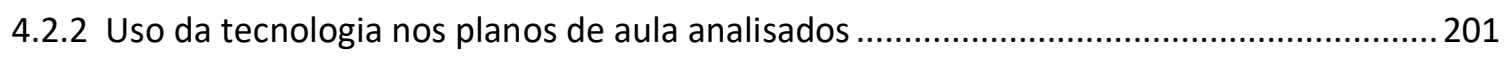

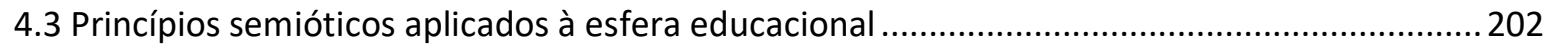

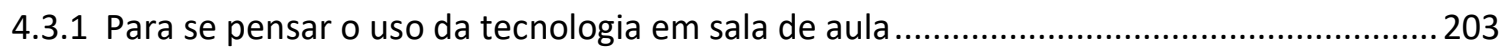

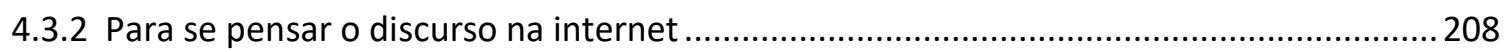

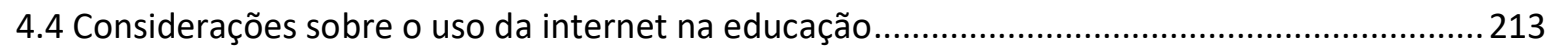

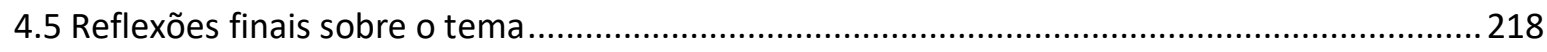

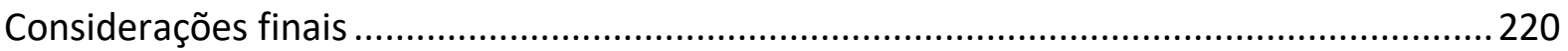




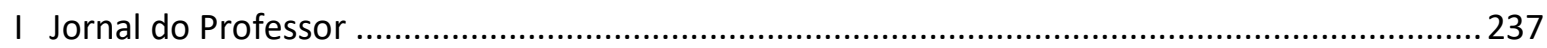

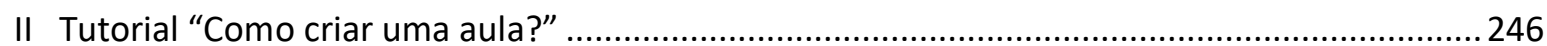

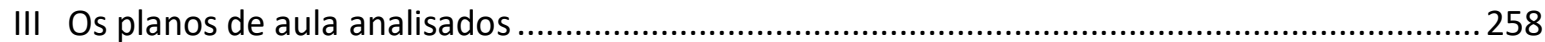




\section{Introdução}

Finalmente, o terceiro aspecto da semiótica pode ser mais bem definido como uma característica especial da psicologia científica do pesquisador, do modo como se forma sua consciência cognitiva. Do mesmo modo que um diretor de filmes olha a seu redor com seus dedos posicionados de modo a emoldurar e 'cortar' pedaços separados da totalidade da vista, do mesmo modo o pesquisador de semiótica tem o hábito de transformar o mundo ao seu redor para evidenciar as estruturas semióticas ${ }^{1}$.

Yuri LOTMAN

Este trabalho se propõe a refletir sobre o modo como se dá a transmissão de conhecimento e a construção do saber nas escolas brasileiras do início do século XXI por meio de análise de um texto construído por professores ou pessoas ligadas à educação escolar e disponibilizado na internet. Busca também refletir sobre a circulação do discurso na internet e os modos como isso afeta os processos de construção do conhecimento dentro do âmbito escolar.

A busca pela aquisição do saber configura-se para nós como uma inquietação que já podia ser identificada no mestrado ${ }^{2}$, ainda que de modo mais difuso, quando estudamos a leitura como um processo semiótico de construção de sentido. No corpus analisado em nossa

\footnotetext{
1 Tradução nossa do original: Finally, the third aspect of semiotics can best be defined as a special feature of the scientific psychology of the researcher, the way his cognitive consciousness is made up. Just as a film director will look at the world around him/her through his/her fingers which are placed to form a frame and to 'cut' separate pieces from the totality of the view, so the semiotic researcher has the habit of transforming the world around him/her so as to show up the semiotic structures. (LOTMAN, Yuri. in the Preface to Universe of the Mind: A semiotic theory of culture. Indiana University Press, 1990)

2 O título de nossa dissertação de mestrado (Unesp, 2006) foi "A viagem de um leitor: uma investigação semiótica do processo de leitura", disponível no site Domínio Público http://www.dominiopublico.gov.br/pesquisa/DetalheObraForm.do?select action=\&co obra=29089 .
} 
dissertação -o romance juvenil Por onde você andou, Robert?, de Hans Magnus Enzensberger $^{3}$ - , o protagonista fazia viagens no tempo, com as quais era possível estabelecer uma metáfora de leitura. Conforme ia viajando para o passado e passando por novas experiências, ele se livrava de objetos que havia trazido consigo. Essas viagens mostravam claramente a transformação de um sujeito que estava em conjunção com objetos que o competencializavam e que passava a ser um sujeito que, a partir da disjunção com eles, ia adquirindo uma competência. Construiu-se, nessa narrativa, um percurso de aquisição de saber e, desse modo, ao final, ele se mostrou um aprendiz autônomo e independente, capaz de voltar ao seu tempo e ao seu mundo. Colocava-se, assim, um percurso de aquisição e construção de conhecimento por meio da leitura, em âmbito individual, mostrado em uma narrativa infanto-juvenil.

A partir desse percurso e voltando nossa atenção para como esse processo se dá coletivamente, o questionamento sobre a aquisição do saber encaminha-se em direção à esfera da educação. Compreender como ela acontece, em termos de organização política, escolar ou individual coloca-se para nós como um ímã de atração por ser parte importante e essencial da competencialização do sujeito pelo saber para uma vida plena. Basta observar o mundo para se ver o papel fundamental que ela exerce na vida das pessoas e da sociedade. Basta olhar as sociedades em que não se tem um sistema de educação suficiente para se perceber os efeitos negativos que sua falta traz. De modo formal, a educação acontece na escola, local social de encontro para aquisição de competência para ser e saber. Mais do que isso, segundo a professora Carlota Boto ${ }^{4}$, as escolas são o local privilegiado onde as sociedades desenvolvem seu processo civilizatório. Para nós, esse processo se traduz, em um sentido mais amplo e condizente com a realidade brasileira do século XXI, como sinônimo de desenvolvimento cultural, plural, inclusivo e que visa ao bem comum de toda a nossa sociedade. As escolas constituem, portanto, a forma institucionalizada como a sociedade se organiza não apenas para dar continuidade à sua cultura, mas também para dar às pessoas acesso à compreensão do mundo, por meio da aquisição de conhecimento para que consigam

\footnotetext{
${ }^{3}$ ENZENSBERger, Hans Magnus. Por onde você andou, Robert?. Tradução de João Azenha Júnior. São Paulo: Companhia das Letras, 1999.

${ }^{4}$ Informação oral, obtida em sala de aula durante disciplina de pós-graduação ministrada por Boto no 2은 semestre de 2015. Essa afirmação se coloca também em referência ao Processo Civilizador, livro de Norbert Elias (publicado no Brasil em 1994 pela Zahar Editores), autor para quem, segundo Carlota Boto, faltou apenas chegar à conclusão de que, a partir da invenção dos colégios, é neles que se desenvolve verdadeiramente o processo civilizador. Ver também Boto (2017).
} 
sair da condição de não-saber e libertarem-se dos preconceitos e de crenças prejudiciais, a fim de serem capazes de conviver entre si e de construírem uma sociedade melhor. A educação então implica a transmissão de saberes e a construção de reflexão que leve a novos conhecimentos.

Para este trabalho, escolhemos para educação a definição proposta pelos estudiosos canadenses Clermont Gauthier e Maurice Tardiff (2014: 29) e que nos acompanhará ao longo das análises e reflexões. Para eles, a educação é:

a ação exercida pelos adultos sobre e com as crianças, com o objetivo de integrá-las a sua comunidade e transmitir-lhes a sua cultura, ou o conjunto de saberes necessários à existência dessa comunidade.

A educação coloca-se, portanto, como uma atividade socialmente organizada, pela qual se transmitem e se constroem esses saberes essenciais, donde se entende que seu lugar de organização social seja, por excelência, a escola. É importante fazer-se aqui a ressalva de que a educação não se restringe à escola, pois ela é muito mais ampla e pode ser transmitida e construída por observação, experiência, aprendizagem informal, convivência... Este trabalho, no entanto, ocupa-se da educação escolar.

Ainda, segundo Gauthier e Tardiff (idem: 30), esse processo de transmissão e construção de conhecimento e cultura não é um processo passivo, como concebido em alguns contextos ou épocas. Antes, trata-se de um processo ativo, modificado por cada nova geração que dele se apodera, adaptado às novas realidades, às novas situações culturais e às necessidades de uma nova geração. Há, no processo de educação, entendido como englobante dessa construção e transmissão de que falamos, uma nova construção de significado a cada geração. Decorre daí sua complexidade e a necessidade de sua compreensão. Note-se que essa complexidade se origina na relação entre o conhecido e o novo, entre o que se sabe e o que se quer saber, entre o saber construído e o saber que se busca construir.

Essa relação entre o velho e o novo nos é trazida por Hannah Arendt, em seu célebre texto "A crise da Educação" (2014 [1954]), no qual a filósofa conceitua que o processo de educação é aquele pelo qual uma sociedade apresenta o mundo, que é velho, aos seus novos habitantes, as crianças, e precisa, ao mesmo tempo, proteger o mundo da novidade, preservando-o, e proteger as crianças do mundo, apresentando-o a elas e responsabilizando- 
se por sua integridade. Cabe ao educador fazer essa mediação entre o velho e o novo, e educar e ensinar a um só e mesmo tempo.

Nessas mudanças que acontecem de uma geração para outra nas formas de ver e transmitir o mundo, tem-se, desde o final do século XX e grandemente intensificado no final da primeira década do século XXI, o uso da tecnologia. Ela acelerou e ampliou sobremaneira, modificando, intensamente, os modos como se acessam informações - e, consequentemente, como se constrói o saber - e modificou também a relação das pessoas com o que se entende como conhecimento e saber. Há uma mudança na percepção dos sujeitos em relação ao processo de aquisição do conhecimento, em cujo desenvolvimento eles se enxergam mais autônomos, porque não mais dependem da escola ou das fontes tradicionais do saber como os professores, por exemplo. Nesse cenário, colocamo-nos, enquanto sociedade, ainda experimentando novos modos de nos relacionarmos com esse "novo mundo", o mundo online. Como esses novos modos afetam a escola? Quais seriam as maneiras de se combinar a escola e a tecnologia na busca e aquisição do conhecimento, do saber? Essas questões também se colocam para nós como de grande importância, neste momento em que as tecnologias estão cada vez mais presentes no cotidiano e que a escola não pode esquivar-se de utilizá-las, de tratá-las e de fazer o melhor uso delas, formando os sujeitos para que as utilizem da melhor maneira.

Para as análises que propomos fazer neste trabalho, utilizaremos a teoria semiótica discursiva desenvolvida por Algirdas J. Greimas e pelos semioticistas que deram continuidade ao seu projeto de criação de uma teoria e de uma metodologia para se apreender a construção do sentido. Para nossas análises, apoiamo-nos principalmente nos estudos sobre enunciação desenvolvidos por José Luiz Fiorin (2002) e Diana Luz Pessoa de Barros (2001) e nos estudos sobre o discurso na internet de Diana Barros $(2015,2016)$. Recorremos também ao Dicionário de Semiótica (GREIMAS e COURTÉS, s/d [1979]), a Denis Bertrand (2003), a Norma Discini (2004; 2015) com o conceito de ator da enunciação e aos regimes de interação desenvolvidos por Eric Landowski (2014). Usamos também, em alguns momentos, os conceitos de semiótica tensiva desenvolvidos principalmente por Claude Zilberberg (2006a, 2011), que entremeiam nossas análises quando nos pareceu necessário.

O trecho de Lotman que consta no início desta introdução foi trazido para não nos deixar esquecer a parcialidade do olhar do pesquisador. Mais ainda, da inevitabilidade dessa 
condição, advinda do fato de que um observador sempre se posiciona para poder observar um objeto ou uma cena enunciativa a partir de determinado ângulo. Adiciona-se a isso que o sujeito que enuncia é também o responsável pelas escolhas das estratégias de construção do texto e ainda, como um editor, responsável pelos recortes que precisaram ser feitos. Dessas escolhas emergem, impiedosamente, suas crenças e um mapa que mostra a geografia das ideias do lugar que ele ocupa no mundo. Eis a grande limitação de todos nós, da qual este trabalho não teve a pretensão de buscar escapar.

Lembremos também de Bakhtin que nos diz, em Marxismo e Filosofia da Linguagem (2006), que a palavra é uma arena de luta e seu significado é construído e destruído pelos diferentes segmentos da sociedade conforme seus interesses. É importante não esquecer da dimensão do conflito como fundamental à linguagem quando se pensa tanto na análise que se empreende de um discurso quanto no objeto analisado e no que ele revela. Cientes dessas limitações, o trabalho que se coloca a seguir busca, de algum modo, modestamente contribuir para o entendimento da educação brasileira por meio do produtivo ferramental semiótico de análise discursiva.

\section{Questões de análise}

Desse modo, a partir do que expusemos brevemente, colocam-se as questões que nos levam a desenvolver esta tese.

Para observar o que se faz nas escolas em termos de transmissão, construção do conhecimento e do saber, buscamos no mundo online alguma coisa que nos mostrasse como isso acontece. Analistas da linguagem que somos, buscávamos algo que já se apresentasse como um texto verbal. Além disso, colocou-se a questão do papel da tecnologia, da internet, como mediador entre o mundo e os sujeitos, e daí pensarmos nesse como um lugar privilegiado de observação e apreensão dessas novas relações.

O sujeito, dentro do espaço escolar, que realiza a transmissão e a construção do conhecimento é o professor, que o faz no espaço da aula. Para entrar em sala e realizar essa performance, ele planeja essa aula, colocando no papel os objetivos, atividades, o modo como 
irá abordar o conhecimento, os alunos, as atividades. Onde isso está escrito, registrado? No plano de aula.

O plano de aula chegou para nós como um texto que nos permitiria acessar o fazer do professor, encontrando suas ideias e concepções reunidas em um só lugar, sobre objetivos, conteúdos, modo de trabalho. Embora expresse seu planejamento da aula e isso seja relevante, ele nos interessa menos por essa razão do que pelo fato de apresentar-se como um simulacro da aula, um texto no qual se encontra um fazer interpretativo na medida em que o professor interpreta leis, diretrizes educacionais, parâmetros curriculares; e um fazer persuasivo na medida em que ele se posiciona como destinador de seus alunos, para transmitir-Ihes e construir com eles um saber.

Além disso, colocou-se como questão relevante para nós o fato de haver planos de aula compartilhados na internet em um site criado e mantido pelo Ministério da Educação, MEC. Isso move esse objeto explicitamente para uma esfera pública, insere-o em um domínio de discursos da internet, afeta-o e o modifica de maneiras que buscamos investigar neste trabalho. O plano de aula sempre teve por destinador e destinatário professores, sincretizados em um mesmo ator, quando se tratava de um texto que circulava em papel, mas, disponível online, traz esses actantes revestidos por diferentes atores. Estar em um site mantido pelo Ministério da Educação acresce a esses planos uma característica relevante: as aulas foram aprovadas pelo MEC e, por isso, espelham também o seu fazer interpretativo dos documentos legais da esfera da educação e seus valores do que seria uma "boa aula". O plano de aula sincretiza para nós a busca pelo saber e a organização da transmissão e construção desse saber na aula, observáveis em um mesmo texto.

A partir dessa constatação, são objeto desta pesquisa os planos de aula que professores e outros sujeitos ligados à educação escolar fizeram e compartilharam no site que o MEC, Ministério da Educação, disponibilizou para essa finalidade (mesmo que esses planos não tenham sido utilizados na sala de aula, o que seria tema para uma outra pesquisa). Nosso objeto se delimita aos planos de aula disponíveis online ${ }^{5}$ no site do Portal do Professor do MEC, que concebemos como o que temos de mais concreto, em termos de documentação escrita e compartilhada online, sobre como o professor entende que deva ser a sua aula, quais

\footnotetext{
${ }^{5}$ No decorrer desta tese, chamamos os planos de aula disponíveis online também de planos de aula online. Referimo-nos ao mesmo objeto, trata-se apenas de uma abreviação.
} 
os conteúdos que ele entende que devam estar na sala de aula, quais atividades farão os alunos se familiarizarem com esse conhecimento. Coloca-se, portanto, como pergunta para investigação nesta tese: como se organizam a transmissão da cultura e a construção do conhecimento no espaço escolar, a partir da análise de plano de aula disponíveis online no Portal do Professor, do MEC?

Há dois recortes feitos para a investigação a que nos propomos. O primeiro deles é tomar como objeto de estudo especificamente o plano de aula compartilhado online. Tratase de uma modalidade de plano de aula que surge em decorrência da internet e dos modos de compartilhar informações criados a partir dela. Em 2008, o Ministério da Educação desenvolveu esse site chamado Portal do Professor, cujo objetivo principal é o compartilhamento de planos de aula (chamados, no site, de sugestões de aula). Nele, os professores, ou outras pessoas, podem criar e compartilhar suas sugestões de aula organizadas por disciplina e tema. Trata-se, assim, de um local privilegiado para observação dessas aulas. O site teve grande expansão de seu uso entre 2009 e 2012, momento em que foi criado e compartilhado grande número de planos de aula. Em 2015, quando começamos a coletar dados, havia mais de quinze mil planos de aula disponíveis, para todas as disciplinas escolares e para os níveis de ensino fundamental e médio. Desde então, tem-se cada vez menos planos de aula sendo publicados, mas acreditamos que, apesar disso, mantém-se a relevância do Portal como objeto de estudo. Existem outros sites que compartilham planos de aula, como o da revista Nova Escola ou o do Portal UOL Educação. O Portal do Professor, no entanto, por ser um projeto do MEC, contém planos que espelham, de alguma maneira, a concepção que também o ministério tem de aula (cabe dizer que os planos, para serem publicados no site, seguem uma estrutura que ele estabelece e precisam ser aprovados por ele). O segundo recorte é que, desses planos de aula, serão analisados aqueles que indiquem língua portuguesa como componente curricular principal (exclusivo ou em combinação com outras disciplinas) e, mais especificamente, que se dirijam aos anos finais do ensino fundamental - equivalentes ao terceiro e quarto ciclos, ou $6^{\circ}$ a $9^{\circ}$ anos. Desse modo, compõese o corpus de análise desta pesquisa.

Desde os PCN de 1998, já se preconizava o uso da internet e das tecnologias de informação como instrumento de ensino, trazendo-as para a escola e a sala de aula. Mais recentemente, a escola passou a ter a concorrência da internet como fonte de conhecimento 
e de construção do saber. O que está na internet é (teoricamente) acessível a todos e, se antes os alunos não tinham outra fonte de conhecimento senão o professor e a escola, essa é uma situação que mudou muito. Há aulas publicadas no YouTube de todas as matérias, há professores formados e pessoas que se autointitulam professores ensinando conteúdo escolar e muitos outros conhecimentos. A internet acaba sendo uma fonte para os alunos, que nela buscam informação e a confrontam com os livros didáticos e com o que o professor traz para a sala de aula. Como o aluno vai saber de onde tirar informação na internet, em quais sites ou tipos de informação ele pode confiar? Trata-se de um conhecimento tão fundamental que vem sendo chamado de letramento digital (do inglês digital litteracy, algumas vezes traduzido como alfabetização digital).

Além dos PCN, a Base Nacional Comum Curricular, BNCC, homologada para o ensino fundamental no final de 2017, traz nas competências gerais o que se espera dos alunos quanto ao uso da tecnologia: "Compreender, utilizar e criar tecnologias digitais de informação e comunicação de forma crítica, significativa, reflexiva e ética nas diversas práticas sociais". Isso traz o uso das tecnologias digitais em sala de aula para um lugar de maior destaque e importância do que elas tinham nos PCN, e está de acordo com o cenário que se mostra atualmente $^{6}$. Desse modo, estabelecemos como foco o uso da tecnologia, já observado nos planos de aula analisados e de crescente importância no cenário educacional. Coloca-se, assim, uma segunda questão de investigação: como a semiótica, com seu ferramental de análise, pode contribuir para melhorar os usos da tecnologia em sala de aula?

\section{Justificativa}

A justificativa para uma análise discursiva do plano de aula disponível online baseia-se no fato de, primeiramente, estar-se frente a um documento bastante tradicional, pertencente à esfera da educação escolar, que espelha a concepção de aula de um professor tanto em

\footnotetext{
${ }^{6}$ Cabe acrescentar que, com o advento da pandemia do novo coronavírus que enfrentamos no decorrer de 2020, quando terminamos esta tese, a importância do uso das tecnologias para a educação aumentou muito. Abordaremos a questão em alguns lugares da tese, pontualmente, e mais especificamente no capítulo 4 e na conclusão. A maior parte de nosso texto foi mantida como estava antes do início dessa situação de distanciamento social pela qual estamos passando (nov./2020).
} 
termos de conteúdo quanto de forma. Trata-se, também, de um documento que ainda não se fez objeto de análise de estudos discursivos. Aliado a esse fato, tem-se que o plano de aula apresenta características decorrentes de seu compartilhamento online, o que implica considerar a internet como lugar de expressão que traz especificidades a esse gênero discursivo.

A internet abre as possibilidades de contato entre pessoas para um número muito superior àquele que se poderia obter pelo contato presencial ou por outros meios utilizados anteriormente a ela, como livros ou materiais didáticos impressos. Para a escola, isso significa uma abertura para a troca de ideias, de impressões, de resultados. Para o professor, uma fonte de ideias e de apoio para criar e executar seu trabalho e para registrar resultados e compartilhar experiências bem ou mal sucedidas. A internet utilizada na escola amplia, de modos que ainda estão sendo verificados e compreendidos, as formas de se apreender e se intercambiar informações e de se construir conhecimento. Por essa caracterização da internet como local e meio pelos quais a escola e, com ela, a educação, se abrem para o mundo, e pela importante necessidade de propostas para que se extraia dela o melhor uso, justifica-se nosso objetivo de propor semioticamente melhores usos para a tecnologia em sala de aula.

Justifica-se também este projeto por sua relevância social, por se propor a analisar um documento da esfera educacional que traz informações sobre conteúdo e modo de ensino, expectativas de aprendizagem, modos de atingir essas expectativas. O plano de aula permite entrever valores ligados à educação e à formação de estudantes que permeiam a sociedade e também valores educativos que aparecem nas bases legais com as quais ele dialoga, em especial os PCN - Parâmetros Curriculares Nacionais, que trazem o modo como se entende que se deve fazer a educação escolar no país no período até a publicação da Base Comum Curricular Nacional, no final de 2017.

Além disso, o plano de aula disponível online, ao permitir investigar o modo como se organizam a transmissão e a construção do saber em uma sala de aula, como já mencionado nesta introdução, traz alguma luz sobre o quê e como se ensina nas salas de aula. Poder-seia argumentar que, como nosso objeto não garante a análise do que se passa em sala de aula, uma vez que ter um plano de aula não necessariamente implica que se tenha a aula realizada, ele teria pouco valor. Ou mesmo se poderia dizer, com base em observações empíricas, 
diálogos com outros professores e também no conhecimento geral que temos de nossa cultura7 $^{7}$, que são poucos os professores que dele fazem uso. Ambos os argumentos são pertinentes, mas não invalidam nosso objeto de estudo, cujo valor está em registrar textualmente um simulacro do fazer do professor em sala de aula por meio de seu planejamento.

Abordar um plano de aula que está disponibilizado online a partir de uma análise discursiva justifica-se por se tratar de um modo de se observar a linguagem colocada em funcionamento, essa que é uma instituição social que veicula as ideologias que circulam pela sociedade e que se constitui como um instrumento de poder (FIORIN, 1988: 6-7). A semiótica discursiva greimasiana, entre as teorias de análise discursiva, se destaca por fornecer um conjunto de conceitos e métodos de análise capaz de estabelecer como se constrói a arquitetura dos sentidos humanos (FONTANILLE, 2016). Ela se coloca como uma ferramenta para se pensar o mundo por meio do estabelecimento de relações significativas (semioses) entre dois ou mais elementos pertencentes a um mesmo sistema e, por meio dela, é possível buscar a maneira como atribuímos sentido às coisas do mundo, na observação de como se organizam as relações entre essas coisas. Sua metodologia de análise tem demonstrado bons resultados e, mais ainda, aperfeiçoa-se continuamente para poder dar conta de novos objetos que surgem.

Finalmente, justifica-se este trabalho como proposta de contribuir com o diálogo que vem sendo retomado com mais força entre a semiótica e a educação, no sentido de que a primeira, com seu ferramental útil à apreensão do sentido dos textos, dos discursos, colocase à disposição da segunda, fundamental para a sociedade, para que juntas possam contribuir para seu aperfeiçoamento como um corpo coletivo cada vez mais ajustado a seus propósitos de compartilhamento do conhecimento e construção de um espaço social democrático. E também para se buscar contribuir para a educação brasileira em tempos de necessidade de reafirmação dos princípios democráticos que nos regem e como único caminho possível para construir a sociedade melhor e mais justa que desejamos.

\footnotetext{
${ }^{7}$ Para uma análise dessa característica brasileira de ser pouco afeita ao planejamento, veja-se o livro "O Valor do Amanhã", de Eduardo Gianetti (Cia das Letras, 2005).
} 


\section{Objetivos}

Como objetivo amplo e geral, esta pesquisa se propõe a investigar como se dá a organização da construção e da transmissão do conhecimento escolar no Brasil no início do século XXI, conforme a visão de quem está em sala de aula, pensando e planejando uma aula de língua portuguesa nas séries finais do ensino fundamental. Para isso, analisa o documento escolar chamado plano de aula a partir de um corpus disponível na internet, no site criado e mantido pelo MEC chamado Portal do Professor. Para essa análise, utiliza-se o ferramental teórico da teoria semiótica discursiva greimasiana.

Além disso, a partir da constatação da forte presença da tecnologia em sala de aula e como meio de circulação do saber, temos por objetivo propor modos como a semiótica discursiva pode contribuir, por meio de seus conceitos, para melhorar o uso das tecnologias digitais em sala de aula, em um momento em que essas tecnologias adentram a escola e a sociedade com grande força e abrangência e necessitam de reflexão e propostas. Em nosso horizonte mais amplo, temos como objetivo contribuir com a busca por meios de se fazer a internet tornar-se um verdadeiro instrumento da educação, refletindo sobre como auxiliar um sujeito a guiar-se por essa busca pelo saber em um vasto mundo digital ao qual ele tem acesso por si mesmo.

Colocam-se como objetivos específicos:

1. Analisar as estratégias discursivas apresentadas nos planos de aula disponíveis online selecionados para o corpus, por meio das quais se apreende o sujeito da enunciação, seus valores e suas estratégias persuasivas.

2. Conceituar o que seja "boa aula" para o MEC e para o professor enunciador do plano de aula disponível online.

3. Verificar qual é o uso que os professores fazem da tecnologia na sala de aula, por meio do que os planos de aula mostram.

4. Propor, a partir da teoria semiótica discursiva, melhores usos da tecnologia na sala de aula e contribuir para as discussões a esse respeito.

5. Contribuir com o debate a respeito da crise da educação, por meio de reflexões a partir das análises empreendidas. 


\section{Plano da tese}

Este trabalho organiza-se da maneira como se descreve a seguir.

O primeiro capítulo estabelece um breve panorama da educação escolar no Brasil a partir dos documentos legais que a regem para que se possa compreender como nosso objeto de estudo, o plano de aula, insere-se nesse cenário e como o uso da tecnologia é prescrito por esses documentos. Apresenta-se o site Portal do Professor, do MEC, onde estão disponíveis os planos de aula que compõem nosso corpus e a análise do entendimento do MEC sobre o que seja planejamento de aula, por meio de análise do Jornal do Professor (do mesmo site), que tem um número exclusivamente dedicado a esse tema. Analisa-se também o tutorial "Como criar uma aula", que se destina a mostrar como fazer uma aula para ser publicada, o que nos permite entrever a concepção de "boa aula", objeto valor buscado pelo sujeito semiótico da falta. Faz-se, também, ao final, uma aproximação com a teoria bakhtiniana pra se pensar o plano de aula como um gênero discursivo.

Em seguida, o segundo capítulo traz uma abordagem da teoria semiótica discursiva em seus aspectos mais relevantes para a análise do plano de aula online, em sua organização narrativa (GREIMAS, 2014; GREIMAS e COURTÉS, s/d [1979]; BARROS, 2001), as questões da enunciação (FIORIN, 2002; BARROS, 2001), dos regimes de interação (LANDOWSKI, 2014) e alguns conceitos da semiótica tensiva (ZILBERBERG, 2006a; 2011; FONTANILLE e ZILBERBERG, 2001). A apresentação da teoria vem em conjunto com a análise do tutorial para a criação de uma aula, disponível no Portal do Professor, do qual se extrai a organização narrativa do que seja um plano de aula online de modo mais genérico e se abordam as questões discursivas que o envolvem.

O terceiro capítulo traz a análise de sete planos de aula disponíveis online. A partir de um corpus estabelecido segundo critérios explicitados no início do capítulo, realizam-se as análises das estratégias discursivas empregadas pelo enunciador, buscando evidenciar os valores que circulam pelos planos, os regimes de interação sobre os quais eles assentam, como se constrói o ator da enunciação do plano de aula disponível online (DISCINI, 2004) e 
qual o uso da tecnologia em sala de aula efetivamente concebido pelo professor, sujeito da enunciação de nosso objeto de estudo.

O quarto capítulo trata de reflexões sobre educação e sobre o uso da tecnologia em sala de aula. Para pensar a crise na educação, apoia-se em Hannah Arendt (2014) e desenvolvem-se reflexões sobre a crise contemporânea na transmissão dos saberes, com base nas ideias de Claudine Haroche (2005) e sobre o conceito de crise, segundo Juan Alonso (2019a) e outros. Para pensar o discurso na internet, busca-se apoio nos trabalhos mais recentes de Diana Barros (2015 e 2016). A partir disso, reflete-se sobre quais conceitos semióticos mostram-se úteis para tratar o uso de tecnologia em sala de aula e colocam-se algumas propostas, a partir das alterações sociais que a internet trouxe desde seu advento e da intensificação de seu uso. 


\section{Percursos da educação escolar brasileira: da legislação ao plano de aula}

Este capítulo inicia-se pela contextualização da educação brasileira a partir da Constituição de 1988 e pelos documentos legais que a regularam a partir de então. Analisa brevemente os objetivos dos Parâmetros Curriculares Nacionais, PCN, de 1998, que estavam em vigor na época em que foram produzidos os planos de aula que compõem o corpus deste trabalho, e também as competências indicadas pela Base Nacional Comum Curricular, BNCC, no que concerne ao uso da tecnologia, que se fazem importantes para a segunda parte deste trabalho. Também se apresenta o site Portal do Professor, do MEC, onde se localiza nosso corpus, bem como sua concepção de planejamento de ensino e de plano de aula, por meio da análise de uma edição do Jornal do Professor (desse mesmo site) sobre planejamento e do tutorial para se criar um aula.

\subsection{0 discurso sobre a educação brasileira do final do século XX e início do XXI}

A Constituição Brasileira de 1988 institui o direito à educação como direito social do cidadão, cujas diretrizes e bases devem ser estabelecidas privativamente pela própria União e cujo acesso deve ser proporcionado pela União em conjunto com Estados, Distrito Federal e Municípios. Em seu capítulo terceiro, artigo 205, estabelece-se que a educação é direito de 
todos e dever do Estado e da família, a ser promovida e incentivada com a colaboração da sociedade, com o objetivo de pleno desenvolvimento da pessoa, seu preparo para o exercício da cidadania e sua qualificação para o trabalho. A partir de 2009 amplia-se o que se entende por dever do Estado com a educação para que abranja a escolarização dos 4 aos 17 anos, inclusive para aqueles que não tenham tido acesso a ela na idade própria.

Colocam-se como princípios basilares do ensino na Constituição Federal brasileira, conforme artigo 206 da Constituição: (i) a igualdade de condições para o acesso e permanência na escola; (ii) a liberdade de aprender, ensinar, pesquisar e divulgar o pensamento, a arte e o saber; (iii) o pluralismo de ideias e de concepções pedagógicas, e coexistência de instituições públicas e privadas de ensino; (iv) a gratuidade do ensino público em estabelecimentos oficiais; (v) a valorização dos profissionais da educação escolar, garantidos na forma da lei, planos de carreira, com ingresso exclusivamente por concurso público de provas e títulos aos das redes públicas; (vi) gestão democrática do ensino público na forma da lei; (vii) garantia de padrão de qualidade; (viii) piso salarial profissional nacional para os profissionais da educação escolar pública, nos termos da lei federal.

Para este trabalho, interessa-nos mais especificamente o segundo item do art. 206, que fala da liberdade de aprendizado, de ensino, de pesquisa e de divulgação do pensamento, da arte e do saber. Essa liberdade é pautada pelas Diretrizes e Bases da educação estabelecidas na lei 9394 de 1996 (LDB 1996), que institui a regulamentação legal do direito à educação. Segundo essa lei, incumbe à União, dentre outras tarefas, elaborar o Plano Nacional de Educação (PNE) e estabelecer competências e diretrizes para a educação infantil e básica que nortearão os currículos e os conteúdos mínimos, ambas tarefas a serem feitas em colaboração com os Estados, Distrito Federal e Municípios. O Plano Nacional de Educação (PNE) é um documento válido por dez anos, o primeiro foi de 2000 a 2010 e o segundo, válido no momento em que escrevemos esta tese, abrange o período de 2014 a 2024.

Dos documentos que vêm sendo elaborados desde a publicação da LDB, o mais recente foi a Base Nacional Comum Curricular, a BNCC, publicada em sua versão final em dezembro de 2017. A BNCC (BRASIL, 2017) tem caráter normativo e define o conjunto orgânico e progressivo de aprendizagens essenciais ao longo da educação básica, aplica-se à educação escolar conforme definido na LDB 9394/96 e está orientada pelos princípios éticos, estéticos 
e políticos que visam à formação humana integral e à construção de uma sociedade justa, democrática e inclusiva, conforme fundamentado nas Diretrizes Curriculares Nacionais - DCN (BRASIL, 2013).

Podemos verificar, pelas datas, que, durante o período que se inicia em 1996, ano da promulgação da LDB da Educação Nacional, até 2013, quando se publicaram as DCN, há um grande hiato de tempo. Cobrindo esse hiato, houve um documento muito importante que foram os Parâmetros Curriculares Nacionais, PCN, publicados em 1998 e que foram a referência curricular até a publicação das DCN em 2013 e, neste momento, deverão ser substituídos pela BNCC, que traz, em maiores detalhes para confecção das partes comuns dos currículos escolares, o que antes eram apenas "parâmetros".

Os PCN já mencionam as tecnologias como parte importante do cotidiano escolar e, a partir de 2008, o MEC inaugura um site na internet chamado Portal do Professor, que tem como incumbência, entre outras, a disponibilização de sugestões de aulas para professores, elaboradas tanto por especialistas do MEC como por professores das diversas regiões do país. Esse site possui, desde 2015, quando começamos a pesquisá-lo, mais de quinze mil sugestões de aula, mas, no momento de escrita desta tese, não tem o mesmo ritmo de publicação dessas aulas como teve entre 2009 e 2012, período que pode ser considerado seu auge, como se vê pela data de publicação da maior parte das aulas que aparecem no ranking de mais acessadas ou mais bem avaliadas.

Assim, podemos ver que, quando grande parte dessas aulas estava sendo publicada, o que existia como documento legal que servia como referência para sua elaboração eram os PCN e é por este motivo que eles serão utilizados neste trabalho de pesquisa para se verificarem os valores que circulam pelas aulas publicadas.

\subsection{Sobre os Parâmetros Curriculares Nacionais, os PCN}

Os Parâmetros Curriculares Nacionais - PCN (BRASIL, 1998a) - originam-se da necessidade de se construir uma referência curricular nacional para o ensino fundamental 
para ser discutida e implantada de acordo com as realidades regionais do país. Eles têm por objetivo construir uma base comum de conhecimento escolar em todo o país e garantir aos alunos "o direito de ter acesso aos conhecimentos indispensáveis para a construção de sua cidadania" (BRASIL, 1998a: 9). Cidadania é apresentada como uma palavra chave, que aparece nas primeiras partes do documento - Educação e Cidadania, no mundo e no Brasil. Na apresentação do documento introdutório, assinada pelo então Ministro da Educação Paulo Renato Souza (1995-2002, no governo Fernando Henrique Cardoso) e dirigida nominalmente "Ao Professor", coloca-se primeiramente "a necessidade de se construir uma escola voltada para a formação de cidadãos" (idem: 5).

Eles foram publicados em 1998 no formato de um documento de introdução geral e de documentos específicos para cada uma das oito áreas de conhecimento escolar, um documento de introdução para os temas transversais e mais um para cada tema. As áreas são: Língua Portuguesa, Matemática, Ciências Naturais, Geografia, História, Arte, Educação Física, Língua Estrangeira. Os temas transversais são: Ética, Pluralidade Cultural, Meio Ambiente, Saúde, Orientação Sexual e Trabalho e Consumo. Os documentos apresentam, para cada área e tema, propostas detalhadas em objetivos, conteúdos, avaliação e orientação didática. Tais itens são desdobrados em ciclos, que correspondem a dois anos de escolaridade, e devem ser incorporados ao projeto educativo de cada escola.

Colocam-se como características dos PCN (1) apontar a necessidade de união de esforços do governo e da sociedade para apoio às escolas na tarefa educativa; (2) mostrar a importância do intercâmbio escola e comunidade, visando integração, compreensão do mundo e inserção nele, a fim de situar as pessoas como cidadãos desde o início de sua escolaridade; (3) evidenciar o sentido e o significado da aprendizagem, comprometer os alunos com a própria aprendizagem e contrapor-se à ideia de que se deve aprender algo porque "um dia será útil"; (4) levar os alunos a desenvolver as próprias habilidades, enfatizando que os conhecimentos socialmente elaborados são a base para a construção da cidadania e da identidade; (5) apontar a necessidade de cada escola de ter seu próprio projeto educativo; (6) ampliar a visão de conteúdo para além de conceitos, inserindo procedimentos, atitudes e valores como conhecimentos importantes; (7) tratar os temas transversais (temas sociais urgentes) dentro da escola; (8) apontar a necessidade de se desenvolver trabalhos que 
utilizem as tecnologias da comunicação e da informação; (9) valorizar o trabalho do docente "como produtores, articuladores, planejadores de práticas educativas e como mediadores do conhecimento socialmente produzido" e destacar a importância de que os docentes trabalhem com os conhecimentos prévios dos alunos e com sua diversidade para o aprendizado de conhecimentos específicos (BRASIL, 1998a: 10-11).

Destacam-se, aos nossos olhos, nesse conjunto de características, a ênfase, conforme já observado, na construção da cidadania, juntamente com a importância da adaptação da escola ao meio em que se insere e ao aluno que chega até ela, valorizando o que esse aluno já tem e ajudando-o a construir-se a partir do que ele já é; ainda, destaca-se a importância da diversidade nacional, de se tratar de temas transversais e de se utilizar as tecnologias existentes para valorizar a escola e aproximá-la do mundo fora dela.

Os PCN pautam-se, conforme explicitado em sua introdução (idem: 15-17), na Declaração Mundial sobre a Educação para Todos (UNICEF, 1990), fruto da Conferência Mundial da Educação para Todos que aconteceu na Tailândia em 1990, convocada pela Unesco, Unicef, PNUD e Banco Mundial ${ }^{8}$. Declara-se que, de acordo com os documentos mundiais (não se explicita quais outros documentos mundiais, além desse citado), a educação deve ser repensada, diversificada, inclusiva e que deve fundamentar-se em quatro pilares: aprender a conhecer, aprender a fazer, aprender a viver com os outros e aprender a ser.

Coloca-se, ainda, um rol de problemas brasileiros enfrentados na virada do milênio e a expectativa da sociedade brasileira (BRASIL, 1998a: 21):

[...] para que a educação se posicione na linha de frente da luta contra as exclusões, contribuindo para a promoção e integração de todos os brasileiros, voltando-se à construção da cidadania, não como meta a ser atingida num futuro distante, mas como prática efetiva.

A segunda parte dos PCN versa sobre a importância de um referencial curricular nacional para o ensino fundamental, de modo a garantir que toda criança ou jovem brasileiro

\footnotetext{
8 Em tempo, o Brasil também é signatário da Declaração de Nova Delhi, assinada pelos nove países em desenvolvimento de maior contingente populacional do mundo em 1993, de compromisso com o desenvolvimento da educação e seu reconhecimento como instrumento de promoção dos valores humanos universais. Pode-se encontrar uma cópia dessa declaração em http://www.direitoshumanos.usp.br/index.php/Direito-a-Educa\%C3\%A7\%C3\%A3o/declaracao-de-nova-delhisobre-educacao-para-todos.html acesso em fev./2018.
} 
tenha acesso a um conjunto de conhecimentos socialmente elaborados e reconhecidos como necessários para o exercício da cidadania para deles poder usufruir (idem: 49). Esse referencial curricular só se concretizou em 2017 com a publicação da Base Nacional Curricular Comum (BNCC) e, por essa razão, reiteramos, este trabalho utiliza os PCN como parâmetros para o desenvolvimento dos planos de aula ora em exame.

Como modo indicado para sua concretização, os PCN propõem quatro níveis: o primeiro foram as discussões, documentos e versões preliminares que o originaram, feitas em nível federal; o segundo ocorreu no nível dos estados e municípios, nos quais se esperava que ele fosse utilizado como recurso para revisões, adaptações ou elaborações curriculares das instituições de ensino dessas instâncias; o terceiro refere-se ao uso dos PCN como base para elaboração do projeto educativo de cada escola e o quarto e último realiza-se em sala de aula quando um professor, seguindo as metas estabelecidas pela escola, elabora seu planejamento considerando o grupo específico de alunos a que se destina. Esse planejamento de aula é feito por meio de planos de ensino (para o ano), desdobrados em planos de aula, nosso objeto de investigação. Tem-se assim que os planos de aula estão previstos nos PCN como modo de realização desses parâmetros, o que justifica nossa proposta inicial de que esse texto que tomamos como objeto de investigação mostra o modo como as ideias sobre educação adentram a sala de aula e nela se realizam.

Sobre a estruturação dos PCN, há, na página 54 do documento de Introdução, um esquema mostrando sua estrutura. Podemos descrevê-lo como um documento que tem objetivos gerais para o Ensino Fundamental, traduzidos em objetivos específicos para cada área do saber, buscando tratar dos temas transversais (já citados nesta tese). Cada área apresenta características e objetivos para cada um dos quatro ciclos do Ensino Fundamental - cada ciclo contempla dois anos, o que cobre da $1^{\mathrm{a}}$ à $8^{\mathrm{a}}$ série. Cada ciclo deve conter objetivos e conteúdos da área para o ciclo, critérios de avaliação e orientações didáticas.

\subsubsection{Os objetivos dos Parâmetros Curriculares Nacionais}


Dos dez objetivos que os PCN trazem para o ensino fundamental, reproduzimos a seguir aqueles que têm mais ligação com o escopo deste trabalho e com as análises que pretendemos desenvolver. Eles regem que o aluno deve ser capaz de (BRASIL, 1998a: 55-56, grifo nosso):

- compreender a cidadania como participação social e política, assim como exercício de direitos e deveres políticos, civis e sociais, adotando, no dia-adia, atitudes de solidariedade, cooperação e repúdio às injustiças, respeitando o outro e exigindo para si o mesmo respeito;

- posicionar-se de maneira crítica, responsável e construtiva nas diferentes situações sociais, utilizando o diálogo como forma de mediar conflitos e de tomar decisões coletivas;

- utilizar as diferentes linguagens - verbal, musical, matemática, gráfica, plástica e corporal - como meio para produzir, expressar e comunicar suas ideias, interpretar e usufruir das produções culturais, em contextos públicos e privados, atendendo a diferentes intenções e situações de comunicação;

- saber utilizar diferentes fontes de informação e recursos tecnológicos para adquirir e construir conhecimentos;

- questionar a realidade formulando-se problemas e tratando de resolvêlos, utilizando para isso o pensamento lógico, a criatividade, a intuição, a capacidade de análise crítica, selecionando procedimentos e verificando sua adequação.

Esses objetivos visam a desenvolver um indivíduo inserido em sociedade, ciente de seus direitos e deveres, crítico e responsável, que se comunica bem por meio do diálogo, que cuida de si e dos outros, que aprende a pensar e a analisar porque tem contato com expressões de arte e de política. Como destacado, coloca-se que o aluno deve utilizar-se das tecnologias para "adquirir e construir conhecimentos". Esse objetivo aparecerá novamente na BNCC (BRASIL, 2017: 9), com o acréscimo de que deverá ser feito de forma crítica, significativa, reflexiva e ética. Deveriam estar refletidos, de alguma forma, nos planos de aula propostos por professores como organizadores de suas aulas.

Os Parâmetros Curriculares Nacionais trazem os temas transversais com base em temáticas sociais que costumavam aparecer em discussões feitas especialmente nas áreas de História, Geografia e Ciências Naturais, mas que, para serem contempladas em sua complexidade, deveriam ser discutidas por mais de uma área. Trata-se de temas que "interferem na vida dos alunos e com as quais se veem confrontados no dia a dia" (BRASIL, 
1998a: 65). Fazem isso baseados na Lei de Diretrizes e Bases, que solicita que os conteúdos curriculares observem a difusão de valores que sejam fundamentais ao interesse social, aos direitos e deveres dos cidadãos, que sejam de respeito ao interesse comum e à ordem democrática. O documento institui que os valores a serem transmitidos para os alunos devem "desenvolver a capacidade dos alunos de intervir na realidade e transformá-la, tendo essa capacidade relação direta com o acesso ao conhecimento acumulado pela humanidade" (ibidem). Referem-se ainda aos temas transversais, desde o título do capítulo no PCN, como "questões sociais urgentes".

Em sua estrutura de conteúdo, como referência curricular, os PCN subdividem-se em (1) concepção de ensino e aprendizagem, (2) objetivos, (3) conteúdos, (4) critérios de avaliação e (5) orientações didáticas. Sua estrutura pedagógica é estabelecida de acordo com a corrente construtivista, baseada em nomes como Jean Piaget, Vygotski e M. Cole. Assim, nos Parâmetros, o conhecimento não é algo situado fora do indivíduo, tampouco construído independentemente da realidade exterior, mas sim uma construção histórica e social, na qual interferem valores antropológicos, culturais e sociais (idem: 71). O documento institui ainda que, para se conhecer a realidade, é necessário interagir com ela, em um processo de construção de significados. Por isso, refere-se também ao conhecimento como "resultado de um complexo e intricado processo de construção, modificação e reorganização utilizado pelos alunos para assimilar e interpretar os conhecimentos escolares" (idem: 72). A proposta é que a escola e o professor estejam atentos ao que acontece ao redor do aluno para utilizar essas influências e propor atividades que favoreçam aprendizagens significativas.

Nos PCN, os conteúdos são "meios para que os alunos desenvolvam as capacidades que lhes permitam produzir bens culturais, sociais e econômicos e deles usufruir" (idem: 74). Devido a seu papel central, pede-se que eles sejam discutidos entre a equipe escolar para sua seleção, organização e tratamento, e que não sejam tratados linearmente, mas como uma teia, em que cada um deles é um nó e nenhum deles é privilegiado em relação ao outro. Isso também significa que não há um caminho único para percorrê-los e que fazer esse caminho é uma tarefa de atribuir significado ao conhecimento que o aluno adquire.

Sobre a seleção de conteúdos, os PCN pedem que se leve em conta sua relevância social e sua contribuição para o desenvolvimento intelectual do aluno e que sejam 
considerados não apenas em seu papel conceitual, mas também em seus papéis procedimental e atitudinal. O papel conceitual diz respeito ao aprendizado do conceito por parte do aluno. Alguns dos verbos que descrevem esse aprendizado são, entre outros, identificar, reconhecer, analisar, comentar, comparar. O papel procedimental refere-se ao saber-fazer e tem verbos descritores como elaborar, compor, planejar, demonstrar, construir (entre outros) e precisa ser tratado como objeto de ensino e não como uma aprendizagem que poderia ocorrer espontaneamente. Ensinar procedimentos significa também ensinar um modo de agir, de pensar e de produzir conhecimento (idem: 77). O papel atitudinal liga-se às normas, valores e atitudes que permeiam todo o conhecimento escolar e apresentam-se como bastante complexas porque envolvem cognição (conhecimentos e crenças), afetos (sentimentos e preferências) e condutas (ações e declaração de intenção). São importantes como fator de formação e de transformação de valores e atitudes e precisam ser cuidadosamente e conscientemente escolhidas pela escola. Os Parâmetros ressaltam que essas três dimensões do conteúdo (conceitual, procedimental e atitudinal) não implicam em mais trabalho ou mais conteúdo a ser ensinado, mas em se ensinar de forma que, evidenciadas, elas auxiliem a construir um desenvolvimento amplo, harmônico e equilibrado nos alunos.

Para os critérios de avaliação, o documento exprime que estão relacionados diretamente às expectativas de aprendizagem, que devem considerar os objetivos e os conteúdos propostos e fundamentais para assegurar que o aluno tenha desenvolvido as capacidades previstas e possa continuar aprendendo no ciclo seguinte. As orientações didáticas significam para os PCN a análise das diferentes relações que ocorrem entre alunosprofessor-saber e das diferentes variáveis didáticas encontradas no processo de ensinoaprendizagem. Trata-se, como nomeia o documento, de reflexões para orientar o professor a como criar situações de aprendizagem. Fecha-se assim, com as orientações didáticas, o capítulo dos PCN que mostra o que constitui uma referência curricular, com concepção de ensino e aprendizagem, objetivos, conteúdos e critérios de avaliação, além das orientações didáticas, como mostramos aqui.

A terceira parte dos PCN coloca como eles devem ser concretizados nas escolas e como o trabalho deve se organizar dentro delas, e a quarta parte traz orientações sobre como é a 
juventude e a adolescência no momento de sua publicação e como se entende que devem ser as relações entre a escola e os jovens e adolescentes. Trata-se de conteúdo bem selecionado e bem apresentado, em ambas as partes.

Para a quinta parte, é trazida a importância dos recursos tecnológicos na sociedade e na educação. Esse documento de 1998 preocupa-se em explicar o que são as novas tecnologias e qual seu impacto na sociedade, apostando na importância de sua utilização para melhorar o processo de ensino e aprendizagem nas escolas, ainda que, naquele tempo, os recursos se limitassem a vídeo-cassetes, vídeo-gravadores, CD-Roms. Menciona a rede de computadores internet apenas ainda em seu início, muito longe da importância que ela adquiriu mais tarde.

Ele traz que:

É preciso que o professor compreenda as transformações que estão ocorrendo no mundo e a necessidade da escola acompanhar esse processo. [...] É fundamental também que o professor esteja disposto a aprender sempre, [...] que se coloque no papel de problematizador de conteúdos e atividades, em vez de continuar no papel de transmissor de conhecimentos [...]. (BRASIL, 1998a: 154-5)

Essa incitação ao uso das tecnologias como aliadas de uma educação de mais qualidade e mais integrada à sociedade trazida pelos PCN concretiza-se na criação do Portal do Professor pelo MEC dez anos mais tarde, em 2008, de onde tiramos os planos de aula para análise neste trabalho.

Os PCN de Língua Portuguesa colocam o trabalho com textos como central no ensino da Língua, e o gênero textual como o fundamento desse trabalho, no lugar das análises gramaticais que imperavam até então. Os alunos deverão ser capazes de interpretar textos que circulam socialmente e produzir textos eficazes para as mais diversas situações. Eles solicitam que a seleção dos textos para os alunos seja feita com base em gêneros que aparecem com maior frequência na realidade social e no universo escolar e também pedem que sejam utilizados textos completos, que o aluno seja levado até o texto e não que se simplifique o texto para levá-lo até o aluno. 


\subsection{Sobre a Base Nacional Comum Curricular, a BNCC}

A Base Nacional Comum Curricular, BNCC (BRASIL, 2017), define a si mesma como sendo um documento de caráter normativo que define o conjunto de aprendizagens essenciais aos estudantes brasileiros, ou seja, trata-se de um norte para a formulação dos currículos de todo o país. Ela estava prevista desde a LDB 9394/96, mas só foi promulgada em 2017 para a Educação Infantil e o Ensino Fundamental e em 2018 para o Ensino Médio. Tratase de um documento orientado pelos mesmos princípios das DCN - Diretrizes Curriculares Nacionais (BRASIL, 2013): éticos, políticos e estéticos, que têm como objetivo a formação humana integral e a construção de uma sociedade justa, democrática e inclusiva (BRASIL, 2017: 7).

A Base pensa o ensino por meio de competências e habilidades, em vez de objetivos de ensino, como se tinha anteriormente nos PCN. Define-se competência como a mobilização de conhecimentos (conceitos e procedimentos), habilidades (práticas cognitivas e socioemocionais), atitudes e valores para "resolver demandas complexas da vida cotidiana, do pleno exercício da cidadania e do mundo do trabalho" (idem: 8). Essa mudança traz uma necessidade de adaptação da concepção da escola para as aulas e o modo de se trabalhar os conteúdos, que passam a ser chamados componentes curriculares. O que se vê, logo após a publicação das Bases (de Ensino Fundamental e de Ensino Médio), é a proliferação de iniciativas de tradução desse novo modo de se conceber e organizar o ensino para ajudar as escolas a compreendê-lo em relação ao que se fazia anteriormente. Podem-se observar atualmente muitos sites de instituições não governamentais, empresas e organizações diversas propondo planilhas que explicam essa nova concepção de ensino por competências.

A Base traz como coluna central de sustentação de sua proposta dez competências gerais que os alunos devem adquirir durante sua vida escolar. Depois, para cada área do saber, há competências específicas. As áreas do saber para o ensino fundamental são cinco: linguagens, com língua portuguesa, arte, educação física e língua inglesa; matemática; ciências da natureza, com o ensino de ciências; ciências humanas, com geografia e história; e ensino 
religioso. Depois, para cada uma das competências específicas, definem-se habilidades ou aprendizagens específicas.

As dez competências gerais relacionam-se ao que foi colocado na LDB e versam sobre: valorização e utilização de conhecimentos históricos (1), exercício da curiosidade intelectual e científica (2), valorização da arte e da cultura (3), utilização de diferentes linguagens e conhecimentos para compartilhar conhecimentos visando o entendimento mútuo (4), não apenas compreensão, mas utilização e criação de tecnologias digitais de comunicação para solução de problemas (sobre a qual falaremos um pouco mais) (5), valorização da diversidade para compreensão das relações do mundo e possibilidade de melhores escolhas (6), construção de argumentação assentada em fatos, dados e informações confiáveis para promoção dos direitos humanos, consciência socioambiental e consumo responsável (7), cuidados com saúde física e emocional própria e alheia (8), promoção de diálogo, cooperação, respeito e resolução de conflitos com acolhimento e valorização das diversidades (9) e, finalmente, ação pessoal e coletiva responsável, autônoma, flexível que levem a tomadas de decisões éticas, democráticas, inclusivas, sustentáveis e solidárias (10).

Dentre essas dez competências, interessam-nos mais particularmente as habilidades 5, sobre o uso de tecnologia, e 7, sobre a construção de argumentação com base em fatos, dados e informações confiáveis. Transcrevemo-las por completo, a seguir (BRASIL, 2017: 910, grifo nosso):

5. Compreender, utilizar e criar tecnologias digitais de informação e comunicação de forma crítica, significativa, reflexiva e ética nas diversas práticas sociais (incluindo as escolares) para se comunicar, acessar e disseminar informações, produzir conhecimentos, resolver problemas e exercer protagonismo e autoria na vida pessoal e coletiva.

7. Argumentar com base em fatos, dados e informações confiáveis, para formular, negociar e defender ideias, pontos de vista e decisões comuns que respeitem e promovam os direitos humanos, a consciência socioambiental e o consumo responsável em âmbito local, regional e global, com posicionamento ético em relação ao cuidado de si mesmo, dos outros e do planeta.

Em primeiro lugar, cumpre notar a diferença quanto ao que está na BNCC para o que continham os PCN em relação ao uso da tecnologia: acresce-se a recomendação de que, além de uso, o aluno seja capaz de compreender e criar tecnologias e, mais ainda, que isso seja feito 
de forma crítica, significativa, reflexiva e ética. Trata-se de um acréscimo significativo em relação aos documentos anteriores e reflete as mudanças no papel cada vez mais central que a tecnologia desempenha na sociedade.

Como consequência desse uso crítico e ético, coloca-se a necessidade de que a argumentação e, podemos acrescentar, a construção do conhecimento, sejam assentadas sobre fatos dados e informações confiáveis. Por isso, buscam-se modos de construir com os estudantes o que sejam fontes confiáveis de informação, como reconhecê-las, o que também é objeto de nosso estudo 9 .

A Base, ainda, na parte em que trata das etapas do ensino fundamental na educação básica (BRASIL, 2017: 61), afirma que é imprescindível que a escola "eduque para usos mais democráticos da tecnologia e para uma participação mais consciente da cultura digital." (grifos nossos). Nesse momento já se pode observar que o uso do "mais" - "uso mais democrático" e "participação mais consciente" - indica que esse uso existe, mas não em grau suficiente, e que é necessário aumentá-lo. Tanto o uso mais democrático quanto a interação mais consciente passam por uma problematização do uso das tecnologias digitais e da busca e utilização de informações confiáveis que se encontram na internet.

Cabe, entretanto, uma justificativa primeiro para a brevidade com que tratamos a Base Nacional neste trabalho e, segundo, para o fato de não analisarmos planos de aula que tenham sido feitos a partir de sua publicação. A Base, tendo sido publicada há pouco tempo, tem prazo de dois anos para ser implementada por estados e municípios. Também, e talvez por isso mesmo, não embasou planos de aula que tenham sido chancelados pelo MEC no Portal do Professor que, na verdade, parou de sofrer atualizações, embora não esteja inativo. Além disso, sua publicação se deu no meio do desenvolvimento desta pesquisa, em uma etapa em que já tínhamos finalizado a coleta e análise dos planos de aula. Cabe ainda colocar que o objetivo de verificar a transmissão e construção de conhecimentos por meio da análise dos planos de aula foi feita, independentemente de eles seguirem o modelo e os valores propostos pelos PCN ou pela BNCC. Por esses motivos, não foram coletados planos de aula que tivessem sido feitos depois da publicação da Base. O interesse deste trabalho pela Base

\footnotetext{
${ }^{9}$ Ver capítulo 4.
} 
situa-se na esfera de observação dos usos que ela propõe para a tecnologia, dos quais trataremos no capítulo 4 deste trabalho.

\subsection{0 conceito de planejamento de aula para o MEC}

O plano de aula, embora seja um documento muito tradicional e comum nas escolas, não é objeto de apuradas definições pedagógicas ou didáticas. Geralmente, nos livros de didática, encontram-se menções a ele nos capítulos sobre planejamento, nos quais se obtêm informações sobre o que ele deve conter e o seu lugar dentro da hierarquia escolar. De seu conteúdo, diz-se que deve trazer os objetivos da aula, conteúdo disciplinar, atividades a serem desenvolvidas e modo de avaliação, ou seja, ele traz em si uma descrição da concepção que o professor tem do processo de ensino-aprendizagem.

Tomando por referência Vera Maria Candau ${ }^{10}$ (2012), tem-se que o processo de ensino-aprendizagem deve ser visto de modo multidimensional e abarcar as dimensões técnica, humanística e político-social. A dimensão técnica diz respeito ao processo como ação sistemática e organizada, à seleção do conteúdo, às estratégias de ensino e de avaliação. A abordagem humanista refere-se às relações interpessoais, que precisam estar no centro do processo. E a político-social é inerente a todo processo que é situado em uma cultura e uma organização social e impregna toda prática pedagógica. Às três dimensões, combinadas, Candau denomina didática fundamental, explicitando que sua construção é um desafio a ser feito em diálogo entre todas as esferas ligadas à educação (sociedade, professores, especialistas). A redução do processo de ensino-aprendizagem a qualquer uma das três dimensões o empobrece muito (e isso foi feito em diferentes momentos da história da didática no Brasil, o que se pode verificar nesse artigo de Candau). Pode-se dizer que o plano de aula espelha o aspecto mais técnico do processo de ensino-aprendizagem, pois traz a descrição do como fazer. As outras duas dimensões, no entanto, estão nele contidas, mesmo

\footnotetext{
${ }^{10}$ Nosso agradecimento ao Professor Sérgio Fabiano Annibal (UNESP-Assis) pela indicação de leitura na área de didática.
} 
que de modo mais átono. Podem ou não ter sido explicitadas nos níveis mais macro de planejamento, no plano de curso ou no projeto pedagógico.

As escolas e as secretarias de ensino costumam ter modelos para o plano de aula que indicam o conteúdo que nele deve constar, com os quais se poderia estabelecer um paralelo com o "modelo" proposto pelo Portal do Professor no tutorial para se criar uma aula, o qual analisaremos no próximo item. Dentro da hierarquia escolar, coloca-se sua relação com o plano de ensino, para determinado ano e disciplina, que se liga ao plano escolar, subordinado ao currículo e ao planejamento de diretrizes municipais, estaduais e federais.

Assim, buscamos depreender a definição de plano de aula para o Ministério da Educação a partir de dois conteúdos do site Portal do Professor. O primeiro é uma edição do Jornal do Professor sobre planejamento escolar. O segundo é o tutorial do site para criar uma aula e publicá-la no Portal do Professor.

\subsubsection{A edição do Jornal do Professor sobre Planejamento Escolar}

O site Portal do Professor, do Ministério da Educação, traz em uma das primeiras edições (a sexta, publicada em 2008) de seu Jornal do Professor, um número especial sobre planejamento escolar ${ }^{11}$, categoria na qual se insere o plano de aula. Essa edição inicia-se com um breve editorial, no qual um enunciador dirige-se a um enunciatário "você" de forma amigável e coloquial, colocando o assunto Planejamento como desejado pelos leitores: "como sempre, o assunto atende aos pedidos dos leitores", "você vai ler, entre outros temas..."; e solicitando ao leitor que interaja com o site: "ajude-nos a escolher o tema das próximas edições", "aproveite para colaborar enviando sugestões...". O uso da debreagem enunciativa (que estabelece a relação "eu" e "tu" no discurso) como estratégia aliado ao tom coloquial e aos convites para participação tem por efeito reforçar a identidade e a

\footnotetext{
${ }^{11}$ Para acessar esta edição do Jornal do Professor, é necessário acessar a página do jornal no Portal do Professor - http://portaldoprofessor.mec.gov.br/jornal.html - e depois selecionar, dentre as edições disponíveis, a que tem por tema o planejamento escolar (datada de 03/10/2008). É possível lê-la online ou imprimir. Para ver todos os artigos, a melhor opção é pedir sua impressão, que pode ser em papel ou em pdf. Foi o que fizemos e que se encontra em anexo.
} 
proximidade entre enunciador e enunciatário, trazendo o enunciatário para o aqui e o agora do enunciador. Ao trazer os professores para serem parte do site, como essa escolha enunciativa permite observar, o Portal cria um efeito de aproximação entre destinador e destinatário e facilita a instalação de um contrato fiduciário entre ambos. O editorial é finalizado por um "Seja bem-vindo!", no singular e com um ponto de exclamação, criando um efeito de entusiasmo pela presença do destinatário no texto, dirigindo-se a ele no singular, o que o personaliza, singulariza e, consequentemente, provoca sua adesão ao texto. Trata-se, portanto, de um início que permite delinear um enunciador que produz uma abertura na direção do enunciatário, com o objetivo de fazer fazer.

Nessa edição, o primeiro artigo é uma entrevista com a professora Marlene Grillo, doutora em Educação e professora da PUCRS. A introdução a essa entrevista traz uma primeira definição de plano de aula:

O plano de aula é uma ferramenta muito importante para o professor. Por meio dele, o educador pode fazer a previsão dos conteúdos que serão dados, as atividades que serão desenvolvidas, os objetivos que pretende alcançar, e as formas de avaliação.

Planejamento da aula, contemplando conteúdos, objetivos, atividades a serem desenvolvidas e avaliação, classificado como ferramenta de grande importância: assim se conceitua plano de aula no Portal do Professor. Ao ser indagada sobre "o que é e para que serve o plano de aula?", Grillo menciona a necessidade de se pensá-lo segundo referenciais filosóficos, psicológicos e sociais. Em seguida, diz:

Um plano de aula tem sempre sua origem num projeto pedagógico institucional que dinamiza as direções do ensino, detalhadas num plano de curso e de unidade. É uma previsão de atividades vinculadas a um plano de ensino mais amplo desenvolvidas em etapas sequenciais, em consonância com objetivos e conteúdos previstos. Serve para organizar a intenção do professor e o modo de operacionalizá-la. Expressa, ainda, as opções desse professor diante de seu contexto de trabalho, que implica pensar simultaneamente o conteúdo e os sujeitos com os quais interage.

Todo plano de aula, além de ser um guia, traz implícitas questões pessoais do professor comprometido com sua tarefa e com seus alunos: por que faço o que faço ao ensinar? o que é uma aula: espaço de parceria ou de resistência? como mobilizar o aluno para aprender? como verificar se o aluno aprendeu? 
Nesse trecho, Grillo explicita o diálogo que se estabelece entre o plano de aula e os outros textos que o circundam e antecedem (projeto pedagógico, plano de curso) e afirma que o conteúdo do plano mostra a organização das intenções do professor e o modo como ele irá fazer a realização dessa intenção de ensino em sala de aula. Ao afirmar que o plano "traz implícitas questões pessoais do professor comprometido", ela está dizendo que o plano de aula mostra mais do que ele parece mostrar. As questões colocadas por Grillo dizem respeito a (i) a motivação que leva o professor ao ensino; (ii) o questionamento sobre os conflitos que se estabelecem no espaço (e tempo) da aula, apoiados na oposição parceria $x$ resistência; (iii) as estratégias de persuasão para levar o aluno ao fazer interpretativo desejado; e, por fim, (iv) uma sanção para verificar a eficácia do próprio modo de fazer. Expressa-se a ideia de que o plano sirva para dois momentos: um anterior à aula, para organizá-la, e o outro, posterior, para se refletir sobre ela. Fala-se em "permanente atitude reflexiva" do professor, para criação e depois recriação das aulas, com o objetivo de tornar a prática do professor mais consciente e sistemática.

Essas afirmações de Grillo corroboram nossa percepção inicial de que o plano de aula espelha a concepção do professor sobre a transmissão e construção do saber que adentra a sala de aula, como se o plano de aula pudesse nos mostrar a leitura que o professor faz do cenário da educação, da seleção de conteúdo, do modo de ensinar que fazem parte de nossa sociedade e cultura brasileiras. O plano de aula pode ser entendido como o fazer interpretativo do professor frente à sociedade, à cultura, à legislação e aos direcionamentos pedagógicos do país para aplicar em sua sala de aula - o que justifica a busca por seu entendimento, tomado como objeto de análise.

Ao ser indagada sobre um modelo a ser utilizado para o plano de aula, a pesquisadora responde que é necessário primeiramente acreditar que se trata de um instrumento pessoal e intransferível de trabalho do professor, por expressar suas concepções teóricas e sustentar suas atividades docentes. E que mais importante do que ter um modelo é o registro dos aspectos que orientam a prática do professor. No Portal, nota-se que o conteúdo apresentase flexível, mas que o modelo não é tanto, pois os planos seguem um padrão estabelecido, um modelo para ser preenchido pelos propositores da aula. Sua observação sobre se tratar de um "instrumento pessoal e intransferível" nos levam a supor que isso se ligue ao fato de 
os planos de aula do site chamarem-se "sugestões de aula" - eles seriam um modelo inicial para uma aula que só o professor, pessoalmente, pode conceber.

Em seguida à entrevista de Marlene Grillo, vêm duas reportagens sobre escolas públicas brasileiras, a primeira reportagem sobre escolas no Pará e em Alagoas que obtiveram melhora significativa no IDEB (Índice de Desenvolvimento da Educação Básica) e que atribuem essa melhora ao planejamento escolar. A segunda é sobre uma escola no Rio Grande do Sul e outra no Ceará que tiveram professores premiados por projetos que desenvolveram junto aos alunos. Os títulos das reportagens são "Planejamento é fator importante no Pará e Alagoas" e "Aulas bem planejadas estimulam aprendizado", respectivamente. Ao final da segunda reportagem, coloca-se o seguinte parágrafo:

Estimulante - De acordo com as duas professoras, é muito mais estimulante trabalhar com projetos inovadores. Planejar aulas tendo como meta um objetivo maior do que os rotineiros, alimenta a vontade de ensinar e estimula o planejamento de novos projetos. Aulas bem planejadas levam ao engajamento da escola e da comunidade e fazem a diferença no aprendizado de qualquer estudante.

Pode-se verificar aqui um estímulo - explicitamente verbalizado - a que se trabalhe com projetos dentro da sala de aula. Esse estímulo encontra resposta em parte dos planos de aula online disponíveis no Portal do Professor, que sugere trabalhos do tipo projeto, de mais longa duração, maior abrangência de conteúdo e envolvendo mais de uma disciplina - os PCN sugerem que se trabalhem projetos que abranjam a disciplina de língua portuguesa juntamente com os temas transversais, abordando sua transdisciplinaridade (BRASIL, 1998a). Há também um estímulo claro ao planejamento como forma de levar ao engajamento dos alunos e da comunidade com a escola e com o aprendizado e como forma de sair da rotina, o que pode ser entendido como uma inovação no ensino também.

A quarta reportagem da edição do Jornal do Professor sobre Planejamento é intitulada "Portal do Professor auxilia a planejar aulas" e se dedica a apresentar o conteúdo do Portal voltado ao professor para auxiliá-lo em seu planejamento de aulas.

Sugestões de aulas de acordo com o currículo de cada disciplina, além de recursos multimídia como vídeos, fotos, mapas, áudios e textos, que tornam o conteúdo mais dinâmico e interessante para o aluno, [...] os conteúdos 
podem auxiliar no preparo das aulas e enriquecer a aprendizagem dos estudantes.

Informa-se que as sugestões de aula (sugestões de planos de aula) estão consoantes ao currículo traçado para as disciplinas e estimula-se a utilização de recursos que dinamizem a aula, com o objetivo de despertar o interesse dos alunos e enriquecer sua aprendizagem. Insere-se nessa reportagem uma fala da coordenadora do Portal do Professor que afirma ser a criação de um intercâmbio de experiências voltadas ao desenvolvimento criativo de estratégias de ensino e aprendizagem um dos principais objetivos do Portal. Espera-se a cooperação mútua dos professores por meio do compartilhamento de suas experiências de aula, algo que se pôde verificar, visto que o Portal, em 2016, contava com mais de quinze mil sugestões de aula. Essa reportagem também apresenta um link para o tutorial do Portal que mostra como criar uma aula e que analisaremos a seguir.

Apresenta-se na sequência uma quinta reportagem sobre a criação de mobiliário escolar (bancos e mesa) a partir de lixo reciclável, com o depoimento da professora responsável por essa atividade em uma escola no município de Catuípe, no RS. À primeira vista, a reportagem não parece estar particularmente ligada ao restante do conteúdo, mas, olhando um pouco mais atentamente, trata do tema da criatividade, já verbalizado como desejável na condução das aulas. Um importante testemunho, colocado em primeiro lugar no texto, logo abaixo da foto dos bancos e mesa criados com latões e pneus, corrobora essa percepção:

Vamos criar novas possibilidades, olhar para nós e para o mundo como se fôssemos um só e assim lutar por uma vida melhor para todos - Deise Cargnelutti.

Deise Cargnelutti é a professora responsável pela criação e a execução do projeto citado. Essa fala incita à criação de um mundo melhor e a que se lute por sua construção. "Criar", "novas possibilidades", "lutar por uma vida melhor" revestem o tema da inovação e da esperança no porvir quando se fala da criação de um espaço para o compartilhamento da experiência entre professores. O "para todos" é inclusivo, extenso, eufórico. Assim, essa reportagem se coloca como transmissora da incitação à criação do novo, que seja melhor para todos, e pode ser vista como representando o espírito de criação do Portal do Professor e do planejamento escolar que ele deseja que seja compartilhado pelos professores que o 
acessam. O "para todos" está mostrado explicitamente nessa edição do Jornal na segunda e terceira reportagens, já citadas, que trazem exemplos de escolas em estados brasileiros fora do eixo São Paulo - Brasília, de onde frequentemente saem as notícias, os exemplos e os planejamentos.

O sexto texto do Jornal é uma entrevista com o professor da Faculdade de Educação da USP, José Cerchi Fusari, na qual ele fala especificamente sobre a importância do planejamento, que precisa ser recuperado. O título da entrevista é "José Cerchi Fusari: 'Planejar evita o excesso de improviso pedagógico'." O que chama a atenção nesse título é o "evitar o excesso de improviso", que parece colocar o improviso pedagógico em um lugar de existência indesejada apenas se excessiva e, ainda, que o improviso é inerente ao fazer pedagógico. Isso já nos dá pistas de que o planejamento pedagógico, que é o que se opõe ao imprevisto pedagógico, ocuparia normalmente um lugar de dimensão menor do que o do improviso. Essa pequena existência (ou pequena importância) do planejamento aparece nas falas seguintes, por exemplo, na introdução da entrevista onde se diz que Fusari "defende a retomada do planejamento educacional como uma atividade realizada durante todo o ano letivo e não somente no início" (grifo nosso). Retomar significa voltar a ter, recuperar após longa interrupção, reiniciar (cf. míni dicionário Houaiss). Coloca-se, portanto, planejamento como algo que não se tem, o que está conforme à percepção do senso comum de que "o brasileiro não planeja", ou mesmo que o planejamento, para o brasileiro, é "desnecessário" e "burocrático" -dois adjetivos que são utilizados nessa entrevista, por Fusari, logo no início. Ele prossegue dizendo que é "importante recuperar a identidade do planejamento na escola como uma vivência, uma atitude" (grifo nosso) para que se crie uma cultura de planejamento, de planos de aula e de ensino que serão benéficos. Note-se que "recuperar" e "retomar" aparecem no dicionário como sinônimos e estão ambos explicitados na fala de Fusari sobre planejamento. Ambos os vocábulos indicam com muita clareza algo que se teve, não mais se tem (ou se tem em um nível aquém do necessário) e se deseja que volte a ter.

Para se criar um plano de aula, Fusari diz que é preciso estar atento aos elementos curriculares básicos: princípios educacionais, trazidos da LDB e adaptados à realidade da escola; objetivos da escola, da disciplina e de cada aula; conteúdo ou recorte do conhecimento produzido pela humanidade que fará parte de cada disciplina; método de ensino, visando a 
produzir aprendizagens crítico-reflexivas; avaliação, processo pelo qual se determina a qualidade e a quantidade de mudanças ocorridas na aprendizagem dos educandos.

Na entrevista com Marlene Grillo, também se coloca que a concepção de planejamento:

[...] tem passado por várias modificações: entendido como instrumento obrigatório, definitivo e inflexível, passando pela dispensabilidade, até chegar quase a sua rejeição.

Essa gradação colocada pela professora para qualificar o planejamento - obrigatório (definitivo e inflexível), depois dispensável e, por último, quase-rejeitado-mostra que se trata de um objeto de valor disfórico para o professor, que tende mesmo à extinção. O MEC, ao dedicar um site para o compartilhamento de "sugestões de aula" (planos de aula sugeridos para execução), mostra buscar reverter essa disforia, tornando-o, ao menos, menos disfórico, mais eufórico. O nome "sugestão de aula" para o plano de aula indica essa intenção de retomada cuidadosa e tonicidade fraca do planejamento da aula, em oposição a um plano obrigatório, de tonicidade forte que se tinha em um passado de prescrições mais acentuadas, e que se utiliza, no conteúdo do plano, de nomes como "o que o aluno pode aprender com esta aula" no lugar de "objetivos", por exemplo, reforçando a característica átona dessa "sugestão de aula".

Tanto a fala de Marlene Grillo quanto a de José Fusari, que são professores da área da Educação de duas respeitadas universidades brasileiras, PUCRS e USP, respectivamente, falam do planejamento escolar e, consequentemente, do plano de aula, como algo desejável, flexível, como uma ferramenta de trabalho que leva à reflexão sobre a prática e como documentação da prática. Colocam-no, também, como algo que deve retornar à prática do professor com uma roupagem mais flexível, mais adequada à contemporaneidade. Fusari coloca, ainda, o planejamento como uma atitude, um valor dado ao pensar e ao refletir.

Ambos os pesquisadores situam o plano de aula em um processo maior de planejamento, que deve ser primeiramente feito pela escola e, depois, ser inserido na sala de aula. Ambos também concordam que não é necessário ter um modelo ou um formulário para se fazer o plano de aula, mas, antes de tudo, tê-lo como um registro de reflexão sobre o processo em que se está inserido na escola. Essa flexibilidade de um modelo, além de dialogar 
bem com os sujeitos contemporâneos que preferem prescindir de modelos e padrões mais rígidos, também busca o diálogo com um professor que, inserido na realidade brasileira de pouco ou nenhum planejamento (conforme o senso comum e também depreensível a partir da análise que fizemos acima), poderá se beneficiar das sugestões de aula contidas no Portal para enriquecer (e planejar!) seu dia a dia.

\subsubsection{Tutorial de como criar uma aula no Portal do Professor}

No site Portal do Professor, para se criar uma aula para ser publicada no Portal, há uma página que traz instruções que, além de estarem disponíveis na página, podem ser baixadas como um documento em formato pdf. Nessa página ${ }^{12}$ informa-se que é possível criar aulas individuais e em equipe, bem como:

[...] criar uma sugestão de aula significa descrever a metodologia utilizada pelo professor no desenvolvimento de um tema do currículo: seu planejamento didático, as atividades e os recursos multimídia que podem ser utilizados.

Há, aqui, uma primeira definição do que seja criar uma sugestão de aula: descrição dos métodos que o professor utiliza para abordar um tema do currículo, sendo que dentro desses métodos estão o planejamento, as atividades e os recursos multimídia utilizados. Importante notar que se colocam recursos multimídia lado a lado com planejamento didático e atividades, o que lhes atribui equivalência de importância. Isso poderia causar um certo estranhamento, não fosse pelo fato de este ser um portal que, embora nem sempre enuncie isso explicitamente, dedica-se à disseminação do uso de tecnologias da informação como ferramenta de ensino, como colocado pelos PCN como objetivo. Analisaremos aqui o documento pdf que pode ser baixado a partir dessa página e que contém as instruções.

Ao se iniciar o cadastro de uma aula, irá aparecer na tela um guia chamado “Orientações para a criação de uma aula”, introduzido pelo seguinte aviso: "Leia com atenção cada item. A garantia de publicação da sua aula dependerá do atendimento a todos esses

${ }^{12}$ http://portaldoprofessor.mec.gov.br/criarAulaOpcoes.html acesso em abril de 2018. 
requisitos." O cabeçalho desse guia contém a mesma informação, de que a aula só será publicada caso atenda a todos os requisitos ali propostos. A estratégia discursiva utilizada nessa primeira instrução é uma debreagem enunciativa ${ }^{13}$, aqui em forma de um diálogo de um "eu" que se dirige a um "tu": "Para que sua aula seja publicada no Portal...". Os requisitos aparecem em seguida em forma de uma lista de itens cuja tônica deôntica é evidenciada pela predominância de construções do tipo "a aula deverá", "os objetivos precisam", "as atividades deverão" e assim por diante. Instaura-se, assim, uma prescrição do enunciador sobre o enunciatário, um dever fazer explicitado tanto na estratégia discursiva escolhida quanto na escolha dos verbos que denotam obrigação.

Essa lista apresenta quatro blocos de informações. No primeiro, pede-se que os objetivos estejam relacionados ao título e às estratégias e avaliação, que a aula tenha uma visão interdisciplinar do tema e que, se possível, seja indicado mais de um nível de ensino ou modalidade. Há nessas três solicitações um traço comum de um pedido de estabelecimento de relações: entre título e estratégias e avaliação, entre disciplinas e entre níveis de ensino. Isso atende aos PCN que demandam que o trabalho em sala de aula não seja estanque e fragmentado, mas sim integrado. Também demonstram uma preocupação com o conjunto da aula, para que ela represente uma totalidade coesa.

O segundo bloco refere-se às atividades a serem desenvolvidas na aula. Pede-se que as atividades contenham toda a orientação necessária ao aluno e que orientem o trabalho que o aluno irá realizar, que não sejam apenas expositivas, que suscitem debates, troca de informação, resolução de problemas, estimulem polêmica e curiosidade entre os alunos. Ao pedir que não sejam aulas apenas expositivas, o Portal está dialogando com as tendências mais contemporâneas de aula que solicitam afastamento do método tradicional de exposição dos conteúdos pelo professor ${ }^{14}$. Esse traço de contemporaneidade, de inserção da escola em um tempo novo, perpassa várias solicitações para a aula e não apenas essa primeira página que aparece no tutorial.

O terceiro bloco de orientações refere-se exclusivamente aos recursos multimídia e questões ligadas à tecnologia, reforçando a necessidade de sua presença nas aulas. E o quarto

\footnotetext{
13 Fala-se sobre operações enunciativas (debreagem e embreagem), no capítulo 2, item sobre enunciação.

${ }^{14} \mathrm{O}$ tipo de aula que se solicita no tutorial é a que desloca o centro das atenções do professor para o aluno.
} 
bloco funciona como um pedido de revisão do conteúdo da aula, uma solicitação de acabamento: que se verifique se não houve plágio, que as fontes das imagens sejam citadas, que o texto esteja revisado, formatado e ilustrado etc.

Resumindo, essa primeira página, que se diz uma lista imprescindível de requisitos a serem atendidos para que a aula possa ser publicada, pede criatividade e cuidado com a aula, que ela não seja convencional e seja bem feita, que desperte nos alunos vontade de aprender (por meio da curiosidade e da polêmica, ou da resolução de problemas). Em um primeiro momento, portanto, o MEC pede que a aula saia do convencional e que aborde um tema de modo interdisciplinar, quebrando as barreiras estanques que são vistas tradicionalmente entre as disciplinas. Trata-se de um pedido de aulas adaptadas ao momento histórico de profusão de uso da internet como fonte de conhecimento e da integração entre os saberes de diferentes áreas.

Trata-se, também, de uma demanda explícita para que a aula se configure como uma narrativa em que um destinador professor exerça o seu fazer persuasivo sobre um destinatário aluno, construindo essa persuasão sobre elementos de integração e de relação dos alunos entre eles e entre a escola e a sociedade. .

A estrutura da aula é divida em partes: autoria, estrutura curricular, dados da aula, estratégias e recursos e avaliação. Para cada uma delas há uma aba na parte superior da tela, que se pinta de cor diferente se o indivíduo estiver trabalhando ou se já tiver trabalhado nela. Junto com o nome dessa parte da aula estão avisos: "você está aqui" e a cor laranja, "preenchido" e a cor verde, e a cor azul escuro, sem nenhuma inscrição adicional, para as abas ainda por preencher. Se o preenchimento estiver incompleto, a aba é vermelha e há um aviso sobre isso. A organização, portanto, mescla o visual com o verbal e mostra-se bem marcada, conforme se pode notar na figura 1 - e há de positivo nisso o fato de o tutorial mostrar, na prática, a organização que solicita para a aula aprovada. 


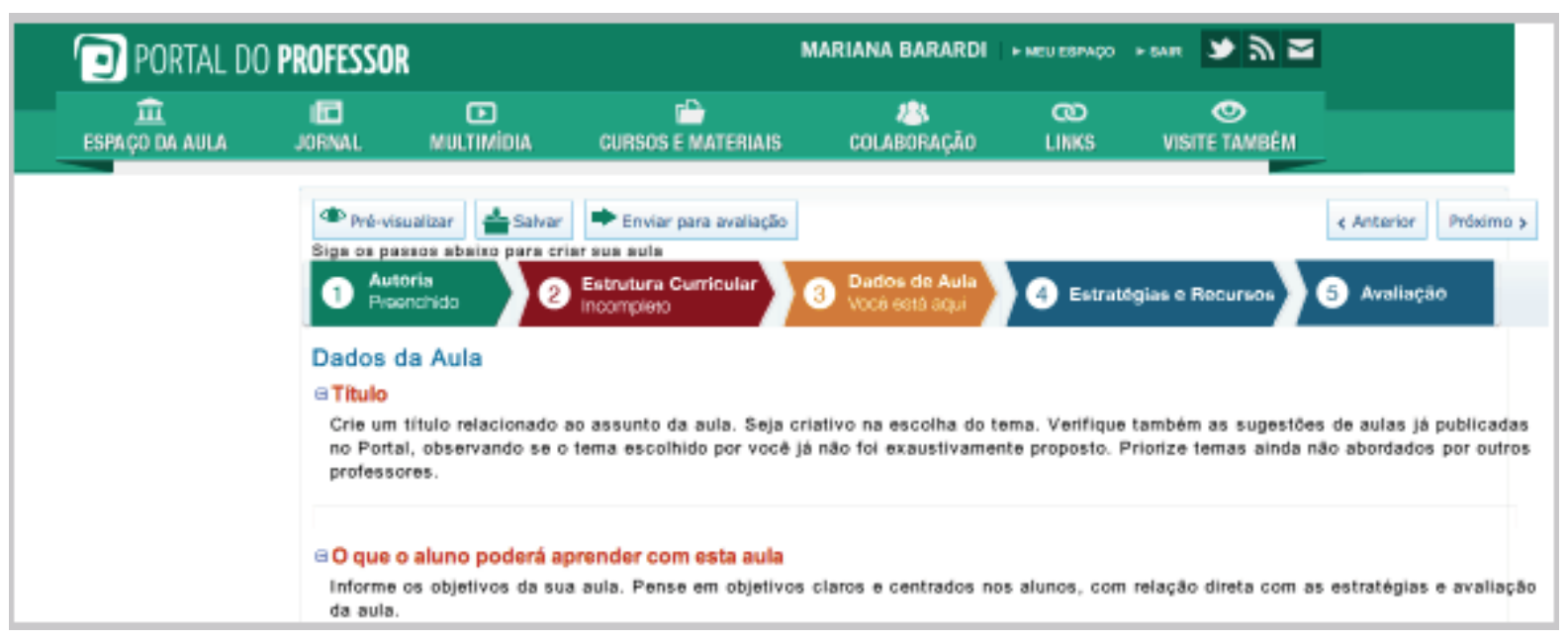

Figura 1 - Organização do Tutorial de criação de aula.

Para autoria, é necessário o preenchimento do nome do autor e da instituição a que ele se vincula. Na estrutura curricular, escolhe-se o nível de ensino (fundamental, médio ou educação de jovens e adultos - EJA), o componente curricular (português, matemática, biologia...) e o tema, também a ser selecionado de uma lista. Podem ser selecionadas mais de uma opção para cada uma dessas estruturas curriculares - o que é desejável, segundo esse tutorial. A seguir vem a seção "Dados da aula", na qual devem ser informados: título da aula, objetivos, duração, conhecimentos prévios trabalhados com os alunos e palavras-chave. Para o título, é dada a seguinte instrução:

Seja criativo na escolha do tema. Verifique também as sugestões de aulas já publicadas no Portal, observando se o tema escolhido por você já não foi exaustivamente proposto. Priorize temas ainda não abordados por outros professores.

Como já havíamos observado, a criatividade é um traço valorizado positivamente e, aqui, opõe-se à repetição (de temas). Em outras palavras, o Portal pede que não se faça "mais do mesmo" e isso irá construir um conjunto diverso, valorizado euforicamente.

A subseção que traz os objetivos tem um nome que explicita sua finalidade: "O que o aluno pode aprender com esta aula". O tutorial pede "Pense em objetivos claros e centrados nos alunos, com relação direta com as estratégias e avaliação da aula." Explicita-se o valor positivo para clareza e relação com as outras partes da aula e, novamente, a necessidade da centralidade no aluno. 
Depois apresentam-se a subseção "Duração da aula", cujo padrão mais comum parece ser a de 50 minutos, a seção onde se devem informar os conhecimentos prévios trabalhados com os alunos, quais os conceitos ou assuntos de que os alunos precisam para compreender ou aprender o que é proposto pela aula e, por fim, as palavras chave, que "permitirão que sua aula seja localizada por outros professores". A localização por palavras-chave é também um valor eufórico, uma vez que esse recurso, na internet, é o que faz um objeto ser localizado dentro do conjunto de objetos afins.

A seção seguinte, "Estratégias e recursos", é aquela na qual se mostra como a aula será desenvolvida. A página que a contém mostra-se dividida em três campos. Um superior, do meio para cima, e um inferior subdividido em dois, conforme podemos ver na figura 2, que mostramos na sequência.

Transcrevemos aqui essa seção do tutorial para que se possa observá-la melhor, pois entendemos ser esse o coração do plano de aula. Na parte superior, a seção inicia-se dizendo:

\section{Estratégias e Recursos}

- Defina o passo a passo de sua ideia de forma clara e objetiva;

- Inicie o primeiro passo com uma atividade criativa e motivadora;

- Evite propor ao professor a introdução das atividades a partir de questionamentos e perguntas, pois essa não é uma forma inovadora;

- Preocupe-se em envolver os alunos mais como atores e agentes do processo do que como ouvintes;

- No desenvolvimento das atividades, estabeleça sempre uma relação clara entre o conteúdo e o dia a dia do estudante;

- Proponha atividades que possibilitem ao aluno debater, construir, colaborar com outros alunos, registrar e divulgar novos conhecimentos.

Na parte interior, aparece uma figura com o passo a passo do preenchimento das informações no portal, onde se lê:

Estratégias e recursos da aula

- Como os alunos poderão atingir os objetivos propostos, por meio de atividades de trocas, as exploratórias, as experimentais, as de comunicação, as interativas, de colaboração e cooperação?

- E como o professor vai ativar esse processo: com situações desafiantes, questionamentos, problematizações, agrupando os alunos por interesses comuns, confrontando os diferentes 
pensamentos dos alunos, refletindo com os alunos os seus posicionamentos?

- Que tipo de ferramentas ou recursos tecnológicos poderão ser colocados à disposição dos alunos? Em que momentos da aula?

- Os alunos terão acesso às produções dos demais, vão interagir e se autoavaliarem? Depois de terem realizado as atividades o que os alunos farão com esses novos conhecimentos, onde poderão aplicálos, onde irão divulgar?

- A aula poderá privilegiar a inserção dos recursos publicados no Portal para que esta, ao ser baixada, permita o acesso aos recursos em locais sem internet. Para isso, clique no botão "Inserir mídia".

Ao lado do quadro que contém essas informações, há uma orientação em letras maiores que diz: "Mais importante que o trabalho do professor é a ATIVIDADE do aluno. Na sala de aula ou no laboratório quem trabalha é o aluno. O professor apenas orienta a atividade do aluno." Enuncia-se aqui, novamente, explicitamente e desta vez com destaque, a centralidade do aluno no processo da aula.

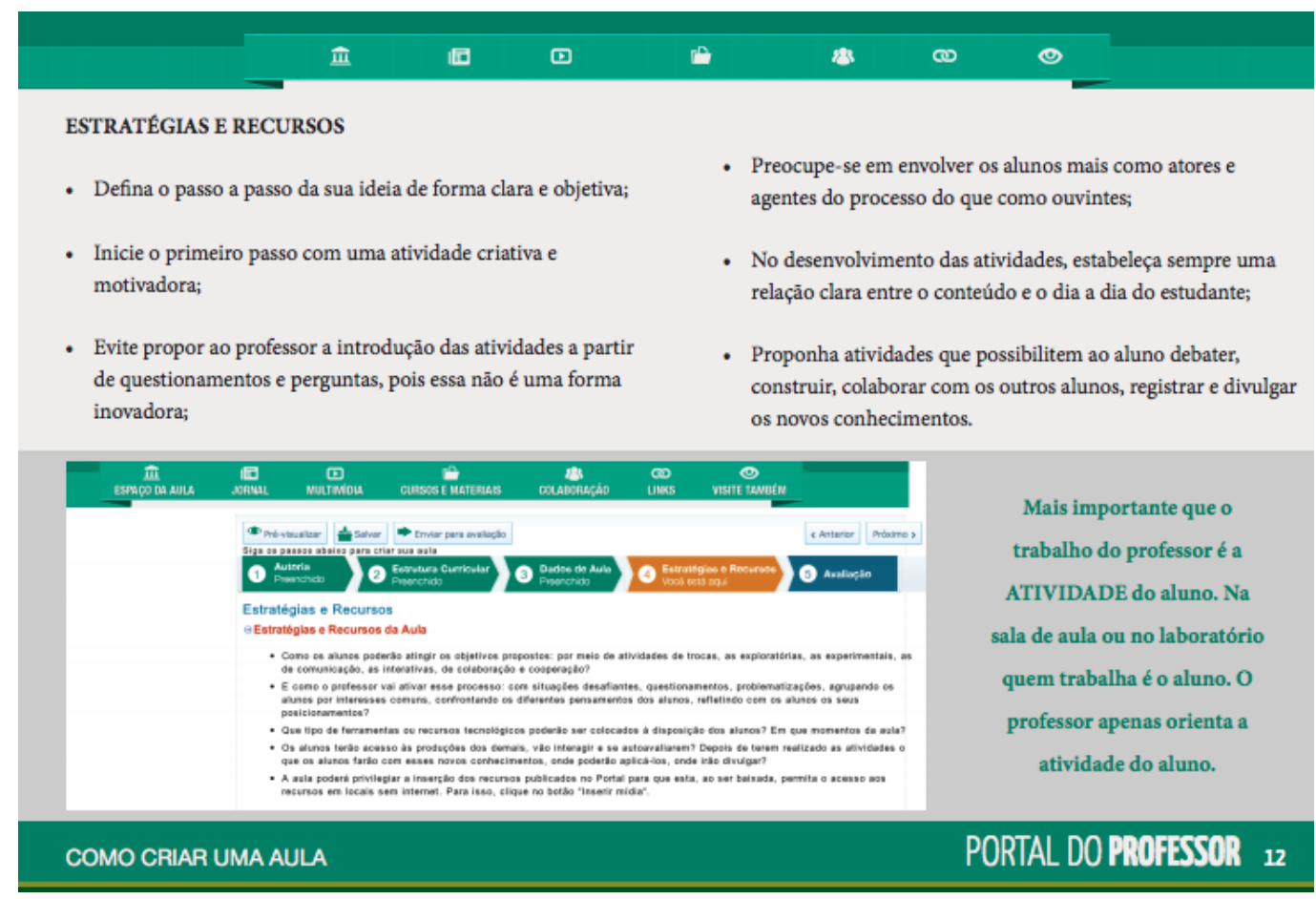

Figura 2 - Seção Estratégias e Recursos do tutorial Como Criar uma Aula, no Portal do Professor.

Nessa seção de estratégias e recursos, localizada na parte de texto na metade superior da tela, a estratégia discursiva é a debreagem enunciativa, com a instauração de um diálogo entre eu e tu, a utilização de verbos no imperativo, frases curtas, organizadas em itens e linguagem direta, como é característico de manuais de instrução. Nomeiam-se professor e 
aluno ao longo do texto como destinatários do discurso que será produzido, o que reforça a caracterização de aula ao se evocarem os papéis temáticos dos envolvidos nessa situação. Quanto aos nomes e qualidades que aparecem, temos "forma clara e objetiva", "atividade criativa e inovadora", "inovadora" (novamente), "relação clara entre o conteúdo e o dia a dia". Destacam-se as ideias de clareza, inovação, criatividade, objetividade, que trazem temas de foria positiva. E, ainda, reforça-se a ideia de relação, que permeia esse tutorial (e os PCN, como já salientamos anteriormente).

Na parte que está descrita na metade de baixo da tela, dentro do quadro branco, há, aparentemente, uma pequena alteração na estratégia discursiva. Eu e tu estão implícitos; quando se diz "como os alunos poderão atingir os objetivos propostos", pode-se entender "como você irá fazer os alunos atingirem os objetivos propostos?" Assim, continuamos a observar uma debreagem enunciativa, embora não explícita, fato que pode ser confirmado pela observação do tempo da enunciação que permanece, explicitamente, em debreagem enunciativa, com a utilização do futuro do presente, em que o referente é um "agora". Com exceção do último item, que dá uma instrução sobre a inserção de mídias no Portal, todos os outros são formados por perguntas que parecem fazer o enunciatário, que aqui é o candidato a autor da aula, projetar-se em seu momento de autor da aula para produzi-la de modo a alcançar as ideias colocadas na parte superior da página, que acabamos de enumerar: clareza, inovação, criatividade, relação entre o conteúdo e o dia a dia do aluno.

Como as estratégias e recursos dizem respeito ao desenvolvimento da aula, voltamos nossa atenção aqui para a palavra "atividade" e o que a cerca, como ela é definida nessa seção do tutorial. Para começar, ela está enunciada em caixa alta em uma frase em destaque na parte inferior esquerda dessa página que diz: "Mais importante que o trabalho do professor é a ATIVIDADE do aluno." Em seguida, diz que "quem trabalha é o aluno", donde se pode inferir que atividade e trabalho podem, aqui, ser tomados como sinônimos. E, ainda, há uma terceira frase nesse texto em destaque dizendo que "O professor apenas orienta a atividade do aluno." (grifo nosso), o que reforça a centralidade do aluno no desenvolvimento das atividades da aula, cabendo ao professor "apenas" orientar. Como se pode ver na figura que reproduzimos acima, há uma divisão dessa página em três campos. A parte superior é única, e a inferior, subdividida em dois. Na parte superior, o lexema Atividade é acompanhado pelas 
qualificações "criativa", "motivadora", "introdução de forma inovadora", "desenvolvidas em relação clara entre conteúdo e dia a dia do estudante", "que possibilita ao aluno debater, construir, colaborar, registrar, divulgar". Na parte inferior, dentro da figura que reproduz a página do site onde será cadastrada a aula, Atividade está ligada aos adjetivos "de troca", "exploratórias", "experimentais", "de comunicação", "interativas", "de colaboração", "de cooperação". A primeira característica a ser notada é o grande número de adjetivações que esse lexema recebe, o que mostra sua importância e centralidade nesse ponto do tutorial. $\mathrm{Na}$ parte superior, têm-se os traços de criatividade e inovação perpassando esse discurso, e a solicitação de que esses traços estejam ligados ao dia a dia do aluno - o novo e o cotidiano colocados juntos para o aluno nas atividades propostas. Essas atividades devem possibilitar relações ativas com o outro: debate, construção, colaboração, divulgação e registro (dos novos conhecimentos). Reforça-se a relação com o outro, o traço de "em comum" nos enunciados da parte inferior da página: atividades "de comunicação", "interativas", "de colaboração", "de cooperação" - desses quatro adjetivos, três possuem o prefixo "co-", originário da preposição latina cum, de companhia. Acrescentados a eles, a locução adjetiva "de troca", que traz em si a ideia de relação, e dois adjetivos, "exploratória" e "experimental", cujo prefixo "ex-" indica movimento para fora, e pode ser interpretado como uma solicitação de que as atividades levem o aluno a movimentar-se para o exterior (de si mesmo? da sala de aula? da escola?) e para o outro, na troca e na interação. Propõem-se, portanto, atividades que transformem a aula em um grande conjunto de alunos ativos, respondendo às demandas da pedagogia de construção conjunta de conhecimento. Há um valor eufórico na relação entre os alunos e na colocação deles como agentes construtores do conhecimento.

Ainda analisando essa mesma página, observemos como se qualifica o papel do professor por meio do que cerca o vocábulo "professor" quando explicitamente enunciado. Na parte superior da tela, "o professor" está enunciado como o destinatário de uma proposição de aula, que, por sua vez, está enunciada negativamente: "Evite propor ao professor...". Infere-se que "a introdução de atividades a partir de questionamentos e perguntas" seja um modo sempre utilizado para iniciar as atividades e que, para essa aula inovadora e criativa, seja inapropriado. Esse modo insere-se no conjunto do mesmo, da repetição, oposto ao valor eufórico da inovação. Pode-se mesmo dizer que há um tom 
levemente negativo, de reprovação à prática habitual desse autor da aula ou desse professor - não fica claro quem é que habitualmente propõe perguntas para se iniciar a atividade, se um ou se o outro, mas pode-se dizer que, em muitos casos, como esses dois papéis temáticos fundem-se em um mesmo ator, entendemos tratar-se tanto de um quanto do outro. Podemos afirmar isso também se nos apoiarmos na quantidade de vezes que, nessa mesma seção do tutorial, aparecem os vocábulos ligados à ideia de inovação e criatividade. Na parte inferior da página, na figura que representa a tela de cadastro da aula, o papel do professor aparece de modo mais positivo, pois ele é quem "ativa esse processo" e age sobre os alunos, agrupando-os, confrontando seus pensamentos ou refletindo com eles. Tem-se aqui um professor mais ativo, mais valorizado positivamente, visto que Atividade, nessa seção, apresenta-se como um lexema de valor eufórico, conforme já analisado. Na terceira divisão da página, a parte que está em destaque, do lado direito, traz um valor associado à figura do professor que poderia ser interpretado tanto positiva quanto negativamente. Uma primeira interpretação dá ao professor valores disfóricos, para que, na outra ponta, o aluno esteja valorizado euforicamente. O professor, nessa parte destacada, é aquele cujo trabalho é menos importante que o do aluno e aquele que "apenas orienta". Enuncia-se explicitamente “Mais importante que o trabalho do professor é a ATIVIDADE do aluno" que, dito desse modo, explicita uma escala de valores na qual o [trabalho do] professor vale menos que [a atividade de] o aluno. Ao se pensar na construção do enunciado, sempre se pode pensar que ele poderia ter sido feito de outra maneira se não quisesse deixar o professor tão abaixo do aluno nessa escala de valores. Na construção de uma aula em que o destinatário desse tutorial ocupa, muitas vezes, ele mesmo o papel de professor, não pode passar despercebida essa opção por explicitar essa atribuição de valores aos atores do processo. Uma segunda interpretação possível atribuiria ao professor o papel mais difícil, de colocar-se às margens do processo de aprendizagem, como condutor, e dar a centralidade ao aluno, qualidade que requereria um professor experiente, hábil e que não estivesse colocado em seu papel habitual, o que mostraria um valor eufórico construído por essa estratégia discursiva. No entanto, a escolha lexical desse pequeno quadro nos faz tender mais à primeira interpretação, a dos valores negativos atribuídos ao professor, pois esse quadro é composto de três orações, relativamente curtas, sendo que duas das três têm "professor" como sujeito e todas contêm 
"aluno" como objeto - em nenhum momento há uma substituição de aluno por um pronome ou por outro termo que servisse como um anafórico, produzindo um sentido de ênfase, o que dá importância à informação, mas também dando a impressão de subestimar a capacidade de compreensão do destinatário daquela comunicação. E se é pelas sutilezas da linguagem que observamos a ideologia que permeia o discurso, observa-se, nesse pequeno trecho, nas estratégias discursivas, uma escolha que coloca o destinatário - o professor que irá criar e compartilhar um plano de aula - em uma posição de menor capacidade. Também se observa com clareza a associação do professor a uma posição periférica e a do aluno a uma central, o que não seria mau, pois é o que colocam as pedagogias de construção do saber, se não fosse essa posição periférica uma diminuição que leva, no limite, ao quase apagamento. Essa posição em que se coloca o professor dialoga com um discurso do senso comum infelizmente bastante difundido de que o professor vale muito menos do que o aluno - ele "apenas" orienta. Em nosso entendimento, trata-se de valores diferentes, não passíveis de serem comparados em uma mesma escala e construções desse tipo corroboram o senso comum vigente.

As cinco páginas seguintes do tutorial, ainda nessa seção Estratégias e Recursos da Aula, são dedicadas a mostrar como funciona a barra de ferramentas de formatação de texto, como se inserem links de outros sites, mídias que farão parte da aula ou fotos e figuras, ou seja, constituem uma parte do tutorial que explica como operacionalizar a parte de tecnologia da informação e a formatação da aula para publicação no meio digital. Trata-se de um espaço grande (cinco páginas) dedicado a esse assunto, o que evidencia sua importância na constituição da aula desejada pelo MEC - uma aula cujo conteúdo associado à tecnologia de informação e às mídias digitais esteja muito presente. Esse longo espaço dedicado ao assunto também é justificado por ser ele uma novidade (em 2008, ano de início das atividades do Portal) e por constituir para o professor um dever fazer. De fato, todos os planos de aula analisados e observados colocam, de algum modo, o uso de alguma tecnologia. Isso também justifica nossa atenção a esse aspecto, exposta no capítulo 4.

A seção seguinte, e última seção do tutorial e do plano de aula que se constrói, é a Avaliação. Nessa seção, há dois textos curtos, um na parte superior da tela, onde se dão as 
instruções, e outro na parte inferior, onde há a figura que reproduz a tela na qual será inserida a avaliação quando se fizer a aula, conforme mostra a figura 3.

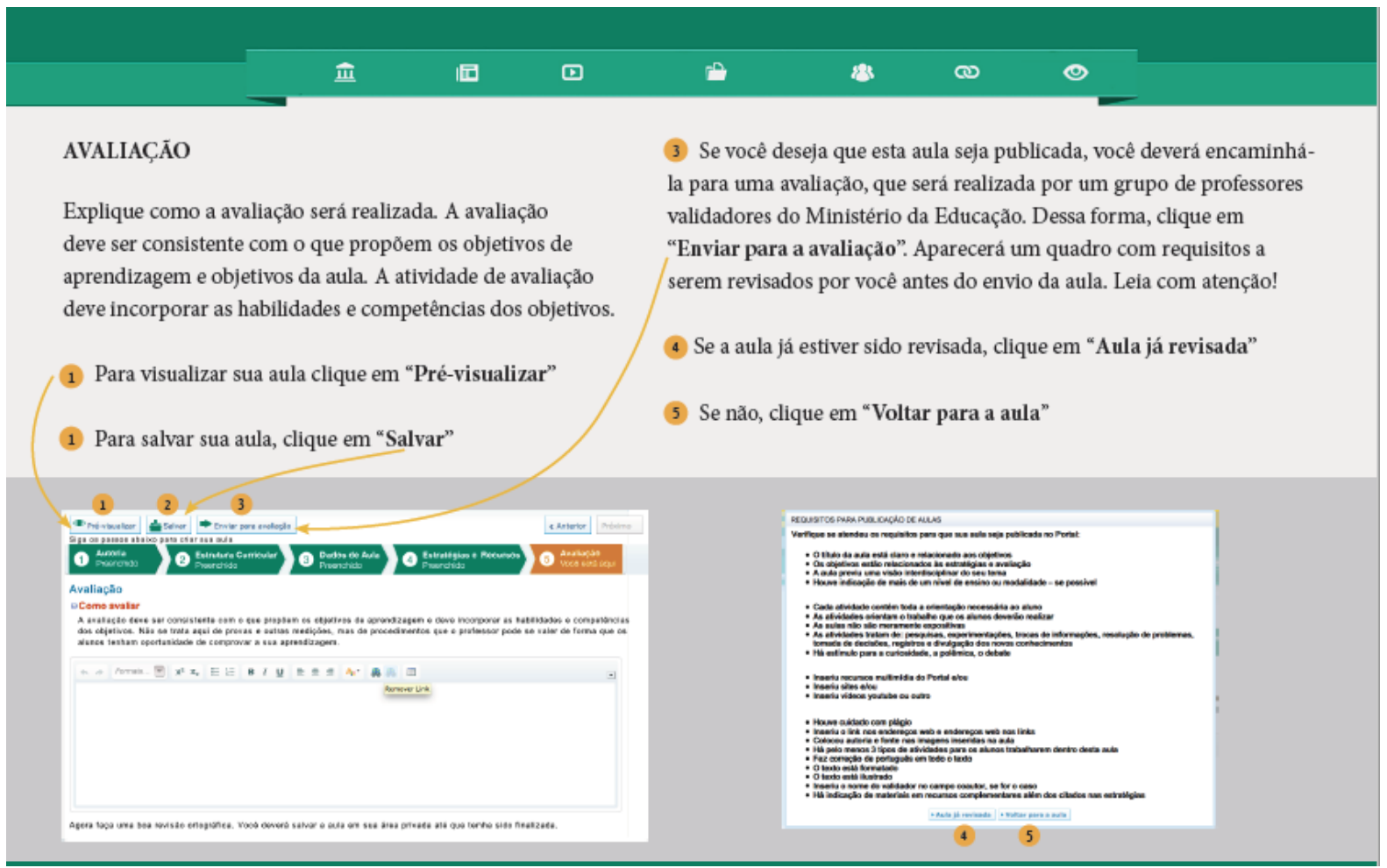

Figura 3 - Seção Avaliação, no Tutorial de Como criar uma aula.

O texto da parte superior diz:

Avaliação:

Explique como a avaliação será realizada. A avaliação deve ser consistente com o que propõem os objetivos de aprendizagem e objetivos da aula. A atividade de avaliação deve incorporar as habilidades e competências dos objetivos.

Na parte inferior, repete-se a segunda frase enunciada acima e completa-se:

Não se trata aqui de provas ou outras medições, mas de procedimentos de que o professor pode se valer de forma que os alunos tenham oportunidade de comprovar a sua aprendizagem.

Nota-se aqui a dupla utilização do "dever", ligado à avaliação. "Deve ser consistente" e "deve incorporar habilidades e competências dos objetivos". Esse pedido de consistência liga-se aos objetivos, tanto os de aprendizagem quanto os da aula, e o fato de ser repetido, no texto da parte superior e no da parte inferior, evidencia a importância que lhe é dada no todo da solicitação. Para o que seja a avaliação, no texto de cima, fala-se em "atividade de 
avaliação", no de baixo, em "procedimentos", esclarecendo não se tratar de provas ou outras medições; ainda, ao final do segundo texto (parte inferior da página), a avaliação é enunciada como "a oportunidade de comprovar a sua aprendizagem [do aluno]". Essa ligação estabelecida e reiterada entre avaliação e objetivos remete ao que é solicitado nos PCN e evidencia na aula a característica de um processo que se completa, pois tem sua etapa final ligada a seu início. O espaço dedicado à avaliação, no entanto, é muito menor do que o dedicado às demais partes da aula - um parágrafo na parte superior da página, outro na parte inferior, enquanto para as outras partes há uma página inteira. Isso nos leva a crer que a importância atribuída a ela seja menor do que às outras partes que foram alvo de explicações mais extensas. Tudo o que se fala sobre essa parte da aula é o que está reproduzido nesse texto. O restante dessa página do tutorial, a parte superior, destina-se a ensinar como finalizar a aula, salvá-la e revisá-la para que seja enviada "para um grupo de professores validadores do Ministério da Educação".

Essa falta de espaço e, consequentemente, de importância, atribuída à avaliação no plano de aula está refletida em grande parte dos planos, que dedicam a ela poucas linhas, de modo bastante genérico. Para nós, trata-se de uma grande falha no fechamento da aula, pois quando não se avalia, não se pode atestar o quanto do que foi ensinado foi aprendido ou, ao menos, apreendido pelos alunos. Se a centralidade é o aluno e seu aprendizado, o professor precisa ser capaz de enxergar melhor e, de algum modo, medir esse aprendizado. Há mesmo, contemporaneamente, metodologias de ensino que propõem que a avaliação seja pensada e planejada antes mesmo das atividades, para que elas estejam intrinsecamente ligadas aos objetivos da aula e que as atividades a serem propostas serão decorrentes do ponto onde se quer chegar, que estará explícito na avaliação ${ }^{15}$.

Na parte inferior dessa página, à direita, aparece um guia de revisão, que contém as mesmas proposições do guia para aprovação da aula, que analisamos no início deste item. A diferença é que, aqui, os verbos, onde possível, estão no passado "Verifique se atendeu os requisitos para que sua aula seja publicada no Portal" (grifo nosso). Ao final, o que se nota é

\footnotetext{
15 Vimos essa concepção de planejamento quando trabalhávamos em um colégio da zona sul de São Paulo, em 2016, trazida por colegas recém-chegados dos EUA. Trata-se do livro de WIGGINS, Grant P. Understanding by Design. Expanded 2nd. ed. 2005. Versão digital em pdf.
} 
a mistura, em uma mesma página, da avaliação da aula contida no plano de aula com a avaliação do plano de aula pelo MEC, para sua aprovação. O mesmo lexema, avaliação, aparece utilizado para ambos os casos.

De um modo geral, o Tutorial para criar uma aula e publicá-la no Portal do Professor apresenta-se como um passo a passo não apenas para mostrar como preencher os campos que farão a aula tomar um formato apropriado para sua publicação, com a inserção de informações pertinentes e de uso dos recursos multimídia, mostrando quais opções escolher e preencher, mas também como um guia de como deve ser uma aula que seja aprovada para publicação. A aula aprovada representa o que podemos chamar de "boa aula", no entendimento do Portal (e, consequentemente, do Ministério da Educação). Isso nos ajuda a definir aquele que, em nossa hipótese inicial, é o objeto valor buscado pelo sujeito professor que procura o Portal.

No tutorial ora em análise, têm-se algumas indicações do que constitua essa "boa aula". Para o Portal, trata-se de uma aula bem estruturada e bem organizada, que estabelece objetivos claros, descreve explicitamente as atividades e utiliza recursos de mídias digitais. Os objetivos ligam-se ao título, as atividades e a avaliação ligam-se aos objetivos, ou seja, as partes da aula inter-relacionam-se formando um conjunto coerente. O professor apresentase como um sujeito criativo e inovador e a aula que ele desenvolve relaciona o novo, que está sendo apresentado ao aluno, ao cotidiano dele. O aluno é ativo e constitui o centro do processo, ele deve trabalhar, debater, polemizar, resolver problemas. A aula solicitada pelo Portal dialoga claramente com os PCN, que eram os parâmetros de ensino para a época e que também prescrevem todas as qualidades que acabamos de enunciar. Dialoga também com a concepção de educação que adotamos neste trabalho, proposta pelos professores canadenses Gauthier e Tardiff (2014), para quem a educação é essa continuação da sociedade por meio da junção do velho com o novo, apresentando o que existe e criando o novo com o educando. O uso das tecnologias digitais dá à aula a roupagem adequada ao século XXI, enquanto a coerência solicitada por ela, traduzida em estrutura e organização, é atemporal. Para o Portal do Professor, essa aula deveria conter algo de novidade do uso da tecnologia, instrumentalizando o professor para dela poder fazer uso, colocando-se esse uso como um valor. 
Esse tutorial constrói em seu destinatário uma imagem do autor da aula como aquele que irá possibilitar aos professores darem melhores aulas: a aula que esse destinatário (do tutorial) concebe, organiza e publica servirá para tornar as aulas dos professores mais atraentes, mais atuais, mais criativas, mais organizadas, em suma, melhores. O futuro autor da aula será um destinador que dará ao seu destinatário, o professor executor da aula, uma competência.

Inserimos aqui uma ressalva devida às circunstâncias que ora atravessamos. No momento de finalização desta tese, em 2020, decorre da pandemia de coronavírus o isolamento social, e o ensino tem funcionado apenas em modo remoto. O uso da tecnologia passa a ser constituinte de todas as aulas (para aqueles que a ela têm acesso, claro) pela impossibilidade da presença física. Opera-se um deslocamento de valor do uso da tecnologia que passa da visibilidade para a invisibilidade, para que os sujeitos não a percebam, para parecer que eles ocupam um mesmo lugar e não que estão isolados. De atriz principal, a tecnologia parece passar a reivindicar o papel de atuar nos bastidores na cena do fazer escolar. Passa-se a buscar, para a "boa aula", fazeres que não apenas atraiam o aluno, mas que o façam se esquecer do suporte tecnológico que passa a ser obrigatório porque inevitável. Quanto mais próxima de uma interação presencial, melhor a aula. Trata-se de um uso da tecnologia que, depois de apenas doze anos, não pode ao menos ser comparado com o que se tinha prescrito ou desejado em 2008, quando se lançou o Portal e se concebeu os textos aqui analisados.

\subsection{0 gênero textual plano de aula disponível online}

Ao buscar analisar o plano de aula disponível online como um texto, faz-se pertinente buscar caracterizá-lo como um gênero textual, buscando a construção do seu sentido e, em um segundo momento, as modificações que podem, e em qual medida, lhe terem sido causadas quanto à sua nova roupagem digital e seu consequente compartilhamento online. 
Bakhtin enuncia que a utilização da língua para fins comunicativos se dá por meio de "tipos relativamente estáveis de enunciados", aos quais denomina gêneros do discurso (2011: 262). Eles aparecem empregados em diferentes campos de utilização da língua e agrupados pelos falantes, que os utilizam mesmo que dele não tenham conhecimento consciente. Bakhtin afirma que a comunicação se dá por meio de gêneros e que isso permite uma economia importante na apreensão da significação, pela antecipação das características e finalidades do discurso que se apresenta. Na composição do gênero estão três elementos: estilo, construção composicional e conteúdo temático.

De "riqueza e diversidade infinitas", os gêneros do discurso permeiam todas as comunicações humanas, da simples conversação cotidiana até os mais elaborados tipos textuais, frutos de condições de convívio humano mais complexo e desenvolvido, como peças de teatro, pesquisas científicas, gêneros publicitários. Não são originalmente prescritivos, como se poderia depreender a partir do que ensinam alguns livros didáticos brasileiros sobre gênero discursivo (ver Fiorin, 2016: 67), mas, como acabam tendo identificadas e atribuídas a si características que a princípio foram necessárias para reconhecê-los e agrupá-los, essas, mais tarde, acabaram fazendo parecer que fossem por elas determinados. As características relativamente estáveis dos gêneros servem, antes de tudo, para seu reconhecimento e para economia no fazer interpretativo do enunciatário, afinal, saber que um texto é, por exemplo, um conto e não um relato já prepara o enunciatário para o contrato de veridicção que se estabelecerá com ele.

Para Bakhtin, os gêneros discursivos relacionam-se não apenas com a comunicação humana, mas também com um de seus conceitos mais centrais, o dialogismo que, para ele, é um princípio constitutivo da linguagem. O diálogo, para ele, se coloca como a condição da linguagem e do discurso. O dialogismo se refere à condição própria da linguagem de trazer em si eu e o outro em interação (conf. Barros, 2011) e de se considerarem pontos de vista divergentes dentro do mesmo signo (conf. Machado, 2005).

São conhecidos e estabelecidos os diálogos entre os estudos semióticos e os estudos sobre gêneros textuais (e a outros conceitos presentes na obra bakhtiniana), como se pode depreender dos estudos de Norma Discini sobre o estilo $(2003,2015)$, de trabalhos de Diana Barros e José Luiz Fiorin (2011, entre outros) sobre dialogismo, polifonia e intertextualidade. 
Bertrand (2003: 87) nos traz que os gêneros textuais estão entre as restrições que moldam e modelam as previsibilidades e expectativas de sentido, impostas pela estrutura e pelo uso, ao sujeito que produz seu discurso.

O plano de aula insere-se na característica de gêneros mais complexos, porque escrito, de caráter documental, pertencente ao conjunto dos discursos escolares, pedagógicos, inseridos na esfera educacional. Os gêneros "mais simples" ou primários estão ligados, sobretudo, à oralidade. O fato de estar contido nessa esfera discursiva já especifica seu primeiro elemento de composição, o conteúdo temático que, embora possa variar grandemente, o faz dentro dos limites determinados pelas coerções estabelecidas pela legislação e pelos parâmetros legais que o cercam. Mesmo que não pareça estar explicitamente inserido nesses parâmetros, o conteúdo estará ainda tacitamente submetido à aprovação das regras culturais e sociais que o rodeiam, sob critérios como adequação a uma faixa etária, a um ambiente, à comunidade na qual se encontra a escola. Pode-se acrescentar ainda que o plano de aula pertence ao grupo dos discursos programadores, como receitas de cozinha ou manuais de instrução, que se caracterizam por neles não haver a transmissão de um querer ou um dever-fazer do destinador ao destinatário, mas que já se iniciam pelo saber ou pelo poder-fazer, pois já encontram esse destinatário modalizado por um querer (ou dever) anterior (GREIMAS, 2014: 169; BARROS, 2001: 95). E, dentro dos discursos programadores, inserimo-lo na subclasse dos discursos de construção de um objeto, que são os que se apresentam como a manifestação de uma competência atualizada e cuja formulação do percurso gerativo se dá em termos de devir: suas etapas, temporalmente estabelecidas como uma sequência de implicações e que se convertirão em um processo, devirão uma aula (GREIMAS, idem).

A construção do plano de aula, como segundo elemento composicional, apresenta-se estabelecida como uma sequência de itens que nele devem constar: objetivos, conteúdo, atividades, avaliação. São partes necessárias, que podem ser desenvolvidas de modo mais extenso e detalhado (como frequentemente é a descrição das atividades), ou de modo mais sucinto (como se nota na maior parte das avaliações). De um ou de outro modo, esses itens estabelecem a organização do que compõe o plano de aula. 
Já o terceiro elemento de composição do gênero textual, o estilo, será objeto de maior detenção de nossa parte. Além de ser um conceito central para o dialogismo bakhtiniano (BRAIT, 2016), o estilo estabelece relação mais estreita com os estudos semióticos discursivos, bastante desenvolvidos por Norma Discini $(2004,2015)$. Brait traz que o conceito de estilo encontra-se disperso em várias obras de Bakhtin, o que obriga o pesquisador a percorrê-las a fim de compreendê-lo. Trabalhado como uma dimensão tanto textual como discursiva em função de cada objeto que será estudado, o estilo forma uma unidade apesar da heterogeneidade discursiva. Na perspectiva dialógica da linguagem bakhtiniana, estilo envolve escolha e isso se dá em função do diálogo proposto entre enunciador e enunciatário. Brait traz de Bakhtin a concepção de que o estilo precisa ser estudado no campo propriamente dito da comunicação e em sua inscrição na língua e nos usos históricos. E também, muito relevantemente, destaca o modo como ele define estilo para "o conjunto dos procedimentos de formação e do acabamento do homem e do seu mundo" (BRAIT, 2016: 87) - estilo como "conjunto operante de procedimentos de acabamento".

Quanto à estreita ligação entre estilo e dialogismo, destacada por Brait (2016), ela vincula-se à relação que se coloca entre os atores da enunciação, pois o estilo que se adota para determinado ato de comunicação atrela-se ao gênero escolhido (ou necessário) para esse ato e, sobretudo, ao modo como se relacionam os interlocutores. Se esses têm alguma intimidade, por exemplo, podem flexibilizar gêneros mais estáveis e adaptá-los a sua comunicação ou mesmo ressignificar enunciados fixos (como exemplo, Beth Brait traz o cumprimento de dois amigos que se saúdam com uma continência militar, ressignificando-a e, provavelmente, adiciona a autora, riem em seguida). Coloca-se assim a dimensão dialógica da linguagem, tão central e essencial em Bakhtin, como condição da linguagem, como estabelecedora das relações de sentido que se instalam entre dois enunciados (FIORIN, 2016: 22).

Para Norma Discini (2015: 91-92), o estilo se define como a depreensão das recorrências de traços do conteúdo e da expressão encontradas em uma totalidade de textos, o que produz um efeito de sentido de individualidade. Essa individualidade não se aplica somente a um indivíduo, e poderia também ser chamada de particularidade, pois pode aplicar-se a um grupo. Tem-se, assim, por exemplo, o estilo paulista ou paulistano, conforme 
exemplificado por Brait (2016), estabelecido por meio de um éthos de trabalho que se figurativiza quer sob a forma da tela Operários (1933), de Tarsila do Amaral, e das diversas releituras que dela foram feitas, quer sob a forma de um dos conhecidos lemas da cidade, "Aqui se trabalha", dentre outros modos. Esse exemplo permite que se entreveja a concepção de estilo em seu sentido coletivo e amplo, o que evidencia sua proximidade da concepção dialógica da linguagem.

A depreensão do estilo se dá também a partir das grandezas de quantificação que compõem essa totalidade estilística e a partir das relações entre éthos, lógos e páthos nele inseridas, as quais, para serem estabelecidas, precisam ser investigadas no modo como se dá a incorporação de uma percepção que se relaciona com o fazer judicativo do sujeito pressuposto à totalidade - o ator da enunciação. Esse ator da enunciação é o sujeito discursivo e o estilo, seu "corpo, voz, tom de voz e caráter", como nos aponta Discini (2015: 92) ao enumerar os fundamentos que norteiam a busca pela apreensão do estilo. Para a semioticista (2004: 28):

[...] cumpre ao analista de estilo (re)construir o ator da enunciação de uma totalidade de discursos. Para tanto, esse ator será observado na recorrência de um fazer e na recorrência de um ser, o que indica o seu aspecto ou o seu modo de ser.

O plano de aula apresenta-se como um simulacro da aula. Há a descrição de um fazer (conteúdos, atividades que serão realizadas e avaliação), precedido por uma explicitação das intenções (objetivos da aula). O professor o faz para mostrar sua concepção da aula para seus registros e para os registros institucionais, daí a educadora Grillo (ver item 1.4 neste mesmo capítulo) dizer que ele "além de ser um guia, traz implícitas questões pessoais do professor". O plano de aula online, por outro lado, possui um autor que se dirige a um outro, um professor que dará aquela aula. Nesse sentido, ele se assemelha mais à proposta de aula contida nos livros didáticos do que ao plano de aula "tradicional" (feito por um professor para documentar suas aulas), porque em ambos o sujeito destinador e o sujeito da ação são diferentes, enquanto, no plano de aula canônico, esses sujeitos são um mesmo ator.

Observa-se, na esteira de Fiorin (2016: 76), que novos gêneros ou a alteração de gêneros já existentes ocasionam novas maneiras de ver a realidade. No caso do plano de aula disponível online, tem-se um gênero existente (o plano de aula) que se apresenta com uma 
roupagem adequada à realidade digital, em uma mudança que a princípio pode ser considerada de suporte, mas que, na verdade, se revela mais ampla. Quanto à construção composicional, não se veem mudanças significativas, pois permanecem as mesmas partes que estruturam e organizam esse texto. Para o conteúdo temático, nota-se a permanência da subordinação aos outros textos que o antecedem e com ele dialogam, e o acréscimo de indicações de fontes digitais de consulta. Indicam-se sites com conteúdo escrito, hiperlinks, vídeos, prescrevem-se modos de criar novo conteúdo (como poemas gravados e disponibilizados na internet ou blogs para mostrar resultados de pesquisa sobre temas específicos). Isso causa no plano de aula online uma característica de maior abertura do que a encontrada no plano de aula tradicional, que ficava restrito (mais fechado) tanto em termos de possibilidade de consulta a outras fontes quanto em termos de exposição à esfera escolar (ele ficava disponível apenas internamente a determinado universo escolar). Pode-se dizer que o plano de aula online apresenta, nesse sentido, um mundo mais extenso, no qual está contido um maior número de possibilidades de acesso ao saber.

É quanto ao estilo que se notam as maiores alterações, na observação das escolhas de léxico, de organização gramatical, de estratégias persuasivas que o enunciador do plano de aula online fará para exercer seu fazer sobre seu enunciatário, em um tempo e um espaço (in)determinados do mundo digital. Os elementos que situam o plano de aula online em uma maior extensão temporal e espacial em relação a seu antecessor "de papel" fazem aumentar a intensidade da percepção do destinatário do plano como um sujeito que se vê frente a muitas possibilidades que lhe são acessíveis de modo rápido por meio dos endereços digitais. Decorre daí a aceleração da percepção e da interação entre esses sujeitos. Decorre também a intensificação de um crer exercido por meio dessas muitas possibilidades que se percebem como promessas de entrega de muito saber, próprias do mundo digital, que o enunciador endereça a seu enunciatário. Tem-se, desse modo, alteração significativa na relação entre enunciador e enunciatário em relação ao plano de aula tradicional. As análises que se apresentarão nos próximos capítulos mostrarão melhor essas características do plano de aula disponível online e suas especificidades. 


\section{Conceitos de análise e o plano de aula disponível online}

A semiótica francesa ou greimasiana, iniciada por Algirdas Julien Greimas em 1966 com a obra Semântica Estrutural (traduzida no Brasil em 1973), buscou estabelecer princípios teóricos e um método para verificar como se constrói o sentido em um texto, e não mais no âmbito da palavra ou da frase, como se fazia até então. Buscava-se "o que o texto diz e como ele faz para dizer o que diz" (BARROS, 2003: 7). Assim, baseado no conceito saussuriano de estrutura ${ }^{16}$, de que um sistema possui relações internas de identidade e diferença que definem seus elementos e da distinção hjelmsleviana de separação entre o plano do conteúdo e o plano da expressão, Greimas construiu um método científico cuja metodologia segura tem mostrado bons resultados de análise. Por meio dela se analisam os discursos sob a forma de um percurso gerativo do sentido: uma disposição ordenada de etapas sucessivas pelas quais a significação passa de simples e abstrata a complexa e concreta.

Tomamos como princípio básico de análise a semiótica desenvolvida originalmente por Greimas (2014 e GREIMAS e COURTÉS, s/d [1979]), apoiando-nos no conceito de narratividade e, mais fortemente, nos estudos enunciativos desenvolvidos por por Diana Barros (2001) e José Luiz Fiorin (2002). Em alguns momentos nos utilizamos de conceitos de semiótica tensiva que foram desenvolvidos posteriormente por Fontanille e Zilberberg (2001), Zilberberg (2006a) e também de sociossemiótica, desenvolvida por Eric Landowski (2014), sobre os

\footnotetext{
${ }^{16}$ Ressaltando-se que Saussure não se utiliza da palavra "estrutura", mas de "sistema".
} 
regimes de interação. Este capítulo apresenta a teoria que sustenta as análises que constam nesta tese, com o intuito de explicitar o ponto de vista e as bases a partir dos quais elas foram construídas. Para fazer isso, analisa o tutorial "Como criar uma aula?", do Portal do Professor do MEC, pois entendemos que ele apresenta uma concepção do que seja um plano de aula para o MEC e também, consequentemente, do que seja uma aula.

Para esta pesquisa, tomam-se os planos de aula disponíveis online mais como discursos do que como textos, embora algumas vezes recorramos também a esta última concepção. Assim, em primeiro lugar, cabe colocar que o discurso é a última etapa da construção do conteúdo no plano gerativo do sentido, ou seja, resultado do enriquecimento e da concretização semântica dos níveis fundamental e narrativo. Ele pertence ao plano do conteúdo dos textos, ou seja, o texto abarca o plano do conteúdo (o discurso) e o plano da expressão e está além do percurso gerativo do sentido (BARROS, 2016b: 73). Embora reconheçamos a importância da análise dos textos, trazendo para as análises o plano da expressão, nesta tese damos preferência às análises do plano do conteúdo, recorrendo algumas poucas vezes ao plano da expressão dos planos de aula online.

\subsection{Sobre a organização narrativa}

O modelo narrativo como concebido por Greimas consiste em uma proposta de se ter um instrumento de análise e de previsão de etapas, que permitirá que se observe o discurso a partir de unidades menores nas quais será possível verificar as transformações e os estados, e o reconhecimento, por catálise ${ }^{17}$, de elementos narrativos anteriores e implícitos (BARROS, 2001: 28). Essas narrativas encontram-se inseridas em uma lógica do devir, implicativa, em que um elemento sucede a outro. Esse modelo serve bem às análises de planos de aula, dadas suas características de ser um texto que documenta o planejamento e a busca de

\footnotetext{
17 “Catálise é a explicitação dos elementos elípticos ausentes na estrutura de superfície. É um procedimento que se realiza com o auxílio dos elementos contextuais manifestados e mediante as relações de pressuposição que entretêm com os elementos implícitos." (GREIMAS e COURTÉS, s/d [1979]: 43)
} 
previsibilidade dos acontecimentos de um processo de ensino-aprendizagem. Para apresentar estes conceitos, utilizamo-nos do tutorial “Como criar uma aula?”, que já foi objeto de algumas análises no capítulo 1.

Parte-se, para a semiótica narrativa, segundo Barros (ibid.), de duas concepções complementares de narratividade: (i) transformação de estados, de situações, operada pelo fazer transformador de um sujeito, que age no e sobre o mundo em busca de certos valores investidos nos objetos; (ii) narratividade como sucessão de estabelecimentos e rupturas de contratos entre destinador e destinatário, dos quais decorrem a comunicação e os conflitos entre sujeitos e a circulação de objetos valor.

Para pensarmos no percurso narrativo do tutorial para se fazer um plano de aula, o que fazemos primeiro é olhar quem são o sujeito e o objeto que aparecem em relação. Um sujeito só existe sintática e semanticamente em relação transitiva com um objeto, e viceversa. Um objeto, por sua vez, ao receber investimentos de projetos do sujeito, torna-se um objeto valor. Os valores que haviam sido colocados na semântica fundamental, neste caso uma oposição entre o ignorar, disfórico, e o saber, eufórico, serão atualizados para o nível narrativo onde aparecem como transformações de um sujeito sobre um objeto ou sobre outro sujeito e nas quais os objetos ganham valor. "Para criar uma sugestão de aula é necessário que você já tenha se cadastrado no Portal do Professor e esteja logado." (p. 2) ${ }^{18}$ Tem-se um sujeito [que quer criar uma aula] em disjunção com um objeto [saber criar uma aula no portal] e que busca entrar em conjunção com ele, ou seja, ele busca uma transformação, de disjunto de seu objeto para conjunto com ele. Tem-se também um outro sujeito, ao qual se chama destinador, que irá atuar sobre o primeiro sujeito para que essa transformação aconteça. Esses são os programas narrativos de base, no tutorial de como se criar uma aula, que descreve o fazer principal e que abarca outros programas menores (denominados programas de uso), de competencialização do sujeito para tarefas que levem ao objetivo principal. Por exemplo, a criação de seu login para entrar no Portal e poder fazer a sua criação de aula, apresentado em um outro tutorial, é um programa de uso.

\footnotetext{
${ }^{18}$ Esta e as próximas frases que aparecerem sem indicação de fonte são retiradas do tutorial "Como criar uma aula?”, disponível em http://portaldoprofessor.mec.gov.br/pdf/tut/tutorial_como criar_uma_aula.pdf, acesso em maio de 2020 e que se encontra nos anexos.
} 
O conjunto de programas narrativos é chamado de percurso narrativo. Na economia da organização da narratividade, tem-se três percursos narrativos distintos: a manipulação, em que um destinador-manipulador competencializa um sujeito para um fazer; a ação, em que esse sujeito faz; e a sanção, em que um destinador-julgador sanciona o fazer desse sujeito.

Na manipulação, um destinador irá dotar o sujeito de uma competência (e aqui estamos na concepção (i) de narratividade que indicamos acima). No tutorial, um destinador doa o seu saber fazer para um destinatário que, depois, terá competência para fazer (ou realizar sua perfórmance). A parte do percurso narrativo da qual se ocupa o tutorial é, portanto, a primeira, a da competencialização do sujeito. As outras duas fases, subsequentes, a perfórmance e a sanção, estão implícitas por pressuposição.

\begin{tabular}{|l|l|}
\hline percurso narrativo & descrição \\
\hline manipulação & $\begin{array}{l}\text { um destinador manipulador competencializa um sujeito para } \\
\text { um fazer }\end{array}$ \\
\hline perfórmance & o sujeito exerce esse fazer \\
\hline sanção & um destinador julgador sanciona o fazer do sujeito \\
\hline
\end{tabular}

Percurso narrativo canônico.

Durante a manipulação, o destinador exerce um fazer persuasivo sobre o destinatário, que, por sua vez, exerce um fazer interpretativo sobre o fazer do destinador. De um lado, um fazer crer e um fazer saber, do outro, um crer, precedido por um ato epistêmico que leve o destinatário a crer. Tem-se que o destinador-manipulador propõe um contrato fiduciário, de estabelecimento de confiança, que será aceito ou recusado pelo destinatário. Essa é a descrição de uma estrutura contratual de comunicação, que representa a concepção (ii) de narratividade, colocada acima.

Assim, para a manipulação, temos um destinador que apresenta um tutorial visando a competencializar o destinatário que, a partir dessa aquisição de um saber fazer, irá realizar sua perfórmance, que é a construção de um plano de aula. A sanção será dada pelo destinador 
julgador, que irá julgar se o plano de aula submetido ao Portal cumpre o contrato proposto de construção de um objeto valor "boa aula" e, sancionando-o positivamente, realizará um programa narrativo de publicação dessa aula no site (que estará contido dentro da sanção). Da caracterização desse percurso narrativo emerge um discurso que se situa dentro de uma classe mais ampla, a de discursos programadores que visam à construção de um objeto, como mostrado por Greimas a respeito da receita da sopa de pesto (2014: 178). Para Greimas (idem: 179), a programação se efetua a partir do término do processo imaginado e, a partir do objetivo fixado, consiste na elaboração dos meios para atingi-lo. Os objetos só interessam e só merecem ter sua construção empreendida na medida em que expressam os valores buscados pelo sujeito e sua construção acontece do ponto de vista do enunciatário pois, para o enunciador, o objeto já é acabado (ou ele não poderia ter programado seu percurso gerativo).

Durante a sanção, além de se verificar o fazer interpretativo do destinatário quanto ao fazer do destinador-manipulador, também é possível verificar seu fazer interpretativo em relação aos documentos legais, dos quais se falou no capítulo 1 desta tese. A "boa aula" construída pelo destinatário responde a ambos os fazeres: o do destinador do tutorial e o do destinador das bases curriculares. Esse segundo destinador não se apresenta explicitamente no tutorial, mas é recuperável por operações de catálise e pelo dialogismo ${ }^{19}$ que se consegue entrever entre as duas instâncias de destinação, afinal, ele Ihe antecede hierarquicamente, englobando-o enquanto pertencente ao conjunto do fazer educativo brasileiro. Há, no entanto, algumas diferenças entre esses fazeres interpretativos. O primeiro responde a uma manipulação por sedução ("se você apresentar uma boa aula, ela será publicada no Portal do Professor"), enquanto o segundo responde a coerções legais (dever seguir a legislação vigente e os documentos legais que prescrevem o fazer educativo).

Torna-se, então, mais explícito que a manipulação do tutorial é para levar o destinatário a fazer uma aula boa o suficiente para que seja publicada. Dentro dessa manipulação há diversos dever fazer, porque a aula só será publicada se cumprir todos os

\footnotetext{
${ }^{19}$ No sentido bakhtiniano, de condição de sentido do discurso, este tomado como um espaço de interação entre sujeitos, entre textos ou entre sujeitos e textos.
} 
requisitos do tutorial. Portanto, o querer que o destinador do tutorial manipula em seu destinatário é o de querer publicar uma aula no Portal.

O Dicionário de Semiótica (GREIMAS e COURTÉS, s/d [1979]) nos traz que o destinador é frequentemente dado como pertencente ao universo transcendente e é ele que comunica ao destinatário-sujeito, no âmbito do universo imanente, os elementos de competência modal e o conjunto de valores em jogo ${ }^{20}$. Olhando para nosso objeto de análise, é possível ver como essa colocação se concretiza. Ambos os destinadores que acabamos de apontar constituem instâncias de mediação entre o destinatário e o universo que o transcende e que influi sobre ele: as regras do Portal do Professor para se publicar uma aula e as regras dos Parâmetros Curriculares para se concebê-la. Para ser sancionado positivamente, o sujeito do fazer deverá ter considerado, na construção de seu objeto, as coerções advindas de ambos universos transcendentes, mostrando-o, desse modo, como um objeto pertencente ao conjunto que mencionamos: que atenda às condições colocadas pelo tutorial e às solicitadas pelos PCN.

O tutorial, no item sobre avaliação da proposta de sugestão de aula ${ }^{21}$, prevê uma sanção parcial, não definitiva, na qual a aula retornará ao sujeito para que nela sejam feitas correções, depois das quais ela poderá ser novamente submetida à avaliação. "A aula só será publicada quando forem atendidos os requisitos mostrados anteriormente." (p. 20). Esse mecanismo de controle assegura que só sejam publicadas sugestões (ou planos) de aulas que estejam totalmente em acordo com as condições estabelecidas no contrato pelo destinador. Assegura também o apagamento de qualquer traço que possa remeter a uma tentativa de quebra contratual por parte do sujeito do fazer, pois as coerções do modo de fazer programado desse discurso não a permitem. Como resultado, os textos publicados estão

\footnotetext{
20 “A oposição imanência/transcendência pode ser utilizada, por outro lado, para explicar, no quadro do esquema narrativo, a diferença entre o estatuto do sujeito e do Destinador. Enquanto o sujeito se encontra inscrito no universo imanente onde realiza seu percurso narrativo adquirindo a competência e efetuando as performances ("realizando-se"), uma subclasse bastante considerável de discursos narrativos coloca o sujeito como Destinatário de um Destinador transcendente, o qual o institui como sujeito com o auxílio da comunicação participativa (que permite comunicar objetos-valor sob forma de doações, sem com isso deles se privar [...])". (GREIMAS e COURTÉS, s/d [1979]: 227, grifos no original).

${ }^{21}$ Fazemos ressalva para que não se confunda essa avaliação com o item avaliação da aula, inserido na sugestão de aula e que tem por objetivo verificar se os alunos aprenderam o que foi proposto.
} 
sempre inseridos na ordem do contrato, da programação e não se recupera neles a estrutura polêmica sobre a qual assentam.

\subsection{Sobre os regimes de interação}

Tradicionalmente, a semiótica narrativa apresentava apenas duas formas de interação: a programação, ou operação sobre as coisas, e a manipulação, ou interação entre sujeitos. Para o semioticista Eric Landowski, em sua obra Interações Arriscadas (2014), é necessário adicionar ao esquema narrativo instrumentos novos de descrição e apresentar dele uma versão ampliada e mais abrangente (2014: 13), a partir de uma noção que ele coloca como pouco considerada até então: a noção de risco. A percepção do mundo é acompanhada pelos regimes de interação e pelos regimes de presença, equilibrando-se precariamente entre continuidades e descontinuidades, identidades e diferenças. A noção de risco liga-se de modo íntimo à noção de sentido. Quanto menor o risco, maior a chance de perda no plano do sentido; a programação, que tem risco mínimo, pode ficar tão previsível até ficar sem sentido. Na outra ponta, o que é muito arriscado também mantém essa relação inversa com o sentido; o acidente, completamente aleatório, pende para o caos e para a falta de sentido. Em ambos os extremos, pode-se romper a interação.

Segundo Landowski, os regimes de construção de sentido são ligados às questões de interação e o sentido, assim como o sujeito, só pode configurar-se dentro de limites, no interior de uma margem estreita, dentro de uma zona intermediária onde as coisas nem parecem tediosamente idênticas umas às outras (identidade, da ordem da continuidade), nem parecem tão diferentes umas das outras que se tornem privadas de relações entre si (diferença, da ordem da descontinuidade). O sentimento de que há sentido supõe uma relação interativa equilibrada entre o mundo e o sujeito, em distâncias equilibradas entre o sujeito e si mesmo e entre o sujeito e o mundo (2014: 16).

Ele propõe quatro regimes de interação, formados a partir das relações de continuidade e descontinuidade: a programação, que tem por princípio a regularidade; o 
acidente (ou acaso), regido pela casualidade; o ajustamento, que atende ao princípio da não regularidade; e a manipulação, regida pela não casualidade. Cada um desses regimes de interação dá lugar a um esquema narrativo governado por uma lógica: a programação, governada pela regularidade, o acidente, pela eventualidade, a manipulação, pela intencionalidade e o ajustamento, pela sensibilidade.

Comecemos, a exemplo do que faz o autor, por conceituar melhor os dois regimes de interação já bem explorados pela semiótica narrativa: a programação, ou operação, e a manipulação, ou estratégia.

Quando se pensa em ação, observa-se que ela se dá de dois modos distintos. Um sujeito que atua diretamente sobre o mundo material e, nesse caso, faz-ser (esse mundo) ou um sujeito que atua sobre outro agente para que ele faça: um fazer-fazer (quem transformará o mundo será um outro actante manipulado pelo sujeito do fazer). No primeiro caso, há interobjetividade e exterioridade e, no segundo, intersubjetividade e interioridade.

Para que um sujeito possa operar sobre um objeto qualquer, é necessário que esse objeto esteja programado. Em termos de gramática narrativa, ele deve ter um papel temático. Esse regime oferece segurança e regularidade. O princípio das regularidades deriva da coerção social, ou mesmo se confunde com ela. Há aqui um modo determinista de apreender o mundo, como se tais regularidades pertencessem de tal modo à ordem das coisas para o sujeito que chegasse a se confundir, para ele, com sua identidade. Há sentido por trás dessas condutas, por mais que este não seja claro ou acessível. Há, entretanto, duas formas de programação: aquela que se apoia em regularidades físicas ou biológicas, procedentes da causalidade, e outra que se apoia em regularidades de comportamento de ordem social ou simbólica.

Quando a interação põe em relação sujeitos, as relações mudam, pois as regularidades comportamentais só podem provir da motivação ou de razões, ou seja, serem fruto de uma estratégia, de uma manipulação. Emerge, aqui, o princípio de intencionalidade. O risco inerente ao êxito em um regime de interação de manipulação seria o de se regressar à programação, que é um regime de interação inferior em termos de possibilidades de criação de sentido (LANDOWSKI, 2014: 63, grifo do autor). A manipulação oferece possibilidades 
narrativas muito maiores (e mais arriscadas) porque põe em relação sujeitos, isto é, actantes que escolhem seus percursos.

O regime do ajustamento comporta mais riscos que os outros dois anteriores, mas, em compensação, abre perspectivas mais amplas de criação de sentido. Esse regime não traz uma interação em que um ator se ajuste completamente ao outro, o que seria uma programação. Se esse ator leva o outro a ajustar-se a si, temos uma manipulação. No regime de ajustamento, o comportamento do ator que interage com outro ator obedece a uma dinâmica própria que não é pré-estabelecida. Os princípios de interação por ajustamento emergem na medida em que a interação acontece e os atores sentem o modo de agir um do outro. No regime do ajustamento, por não estar limitado à execução de algoritmos préestabelecidos, o comportamento do ator varia em função da diversidade dos contextos. Como na manipulação, regime com o qual possui aspectos em comum, no ajustamento as mesmas causas não produzem sempre o mesmo efeito.

Landowski afirma (2014: 49) que tanto o ajustamento quanto a manipulação constituem práticas mais arriscadas do que a programação por dois motivos. Primeiramente, porque o comportamento da interação pode variar em função da diversidade dos contextos, ou seja, as mesmas causas não produzem os mesmos efeitos. Em segundo lugar, o fazer do outro ator, aquele a que se manipula ou ao qual se ajusta o sujeito destinador, não está encerrado nos limites de um papel temático, mas suspenso às reações abertas de uma "competência". Essa competência pode ser de duas ordens, que é o que vai diferenciar o regime de manipulação do de ajustamento.

A competência dos sujeitos manipuláveis é uma competência modal - trata-se de uma gramática narrativa dominada ou determinada pelo elemento cognitivo. O postulado de base é que, para fazer um sujeito querer fazer, é necessário, antes, fazê-lo crer ou saber que há uma vantagem para si nessa manipulação. O destinador concebe o destinatário como um ser consciente de si mesmo e seguro de seus interesses e paixões e, a partir daí, dirige-se a ele por meio da comunicação persuasiva. O manipulador estrategista dirige-se à racionalidade ou às motivações do destinatário. No processo de ajustamento, no entanto, o modo de um ator influenciar o outro passa não mais pelos caminhos dos objetos autônomos, mas pelos caminhos do contato. Temos interactantes, em uma ação entre iguais, cujas dinâmicas de ação 
são coordenadas por meio de um fazer conjunto. O que os rege é uma capacidade de sentir, o que foi batizado por Landowski de competência estésica (2014: 50). Por isso, essa interação não se assenta mais sobre um fazer crer, mas sobre um fazer sentir.

No regime de interação por ajustamento, o sujeito pode ser definido como ator ao mesmo tempo estesicamente apto a perceber o mundo e modalmente apto a lhe atribuir sentido (2014: 53) - o que abarca, sob esse regime, tanto a sensibilidade quanto a motivação. Necessário dizer ainda que nenhum dos atores sob esse regime consegue planejar de forma exata e antecipada o resultado de sua interação com outro ator. A interação pelo regime de ajustamento requer que os atores da enunciação tenham mais clareza um sobre o outro: a imagem que o enunciador constrói do enunciatário precisa ser, antes de tudo, a imagem de um sujeito dotado de competência e de querer.

Para Landowski (2014), a intencionalidade está sempre presente nas interações humanas, mesmo que de modo não consciente. No plano de aula, fica bastante evidente esse fazer do destinador sobre seu destinatário.

[...] toda escolha estratégica expressa essencialmente a maneira como o manipulador constrói a competência (volitiva, deôntica, cognitiva, epistêmica etc.) do outro e o modo como localiza os pontos sensíveis, as falhas ou as zonas críticas, suscetíveis, a seus olhos, de fazer manipulável seu interlocutor (ibid.: 30 ).

O reconhecimento do outro como sujeito para que ocorra a manipulação se dá apenas à medida que se procura conhecê-lo visando a aumentar a segurança da manipulação e a diminuir o risco de que ela não funcione. Entre programação e manipulação, há uma variação nos limites que as distinguem em função da relatividade dos contextos ou das culturas. Também há uma variação causada pela pluridimensionalidade e pela polissemia das grandezas das coisas com as quais tratamos. O sentido, é necessário não se esquecer disso, não se encerra objetivamente nas coisas, nem subjetivamente nos pontos de vista que o buscam (ibid.: 34). Daí a pluridimensionalidade citada. Landowski (idem: 39) afirma ainda que o conjunto dos comportamentos humanos depende da motivação e do princípio de intencionalidade, o que coloca o regime da manipulação e as competências modais como centrais nas interações humanas. 
A existência, ao menos aparente, de fenômenos cuja aparição não pode ser explicada por nenhuma relação ou causa leva a se pensar na existência de um quarto regime, o do acidente, regido pela aleatoriedade. Nele não parece haver actantes, pois esses teriam que, de alguma sorte, ser regidos por motivações ou intencionalidade. Landowski (2014: 76) fala em, no limite, tratar-se de um autodestinador, o que ele também coloca como paradoxal porque o acaso, por definição, não depende de nada que the seja exterior. Ou então, como segunda hipótese, tratar-se de um fatalismo, uma instância hierarquicamente superior "da qual depende o destino dos sujeitos aos quais ela atribui soberanamente favores e desgraças." (idem: 77). O acaso transgride esquemas actanciais conhecidos e não tem a ele uma competência atribuída: nem modal, porque não é motivado; nem de ordem estésica, porque não é sensível a nada. Não tendo competência, é preciso que tenha ao menos um papel, que deve ser o oposto ao temático. Trata-se, portanto, de um actante joker (coringa, em português), cujo papel é ou não ter papel nenhum, ou poder cumpri-los todos, indistintamente.

Sobre a manipulação, o autor ainda nos diz que ela corresponde a um fazer querer fazer. Ela depende do reconhecimento dos valores serem os mesmos entre o sujeito manipulador e o sujeito manipulado. "De um modo mais geral, toda manipulação consiste do mesmo modo em fazer outrem desviar-se de sua trajetória para orientá-lo a uma atividade que, para ele, está 'fora do programa'” (2014: 93). Busca-se persuadir o outro do "valor do valor". Procurar fazer o outro aceitar uma manipulação é procurar fazê-lo aceitar uma determinada maneira de hierarquizar valores, construir uma axiologia comum. A significação última da manipulação é "um passo rumo a uma re-fundação do social enquanto universo de sentido e de valores assumidos e partilhados." (2014: 93, grifo do autor).

Colocados os quatro modos de interação com seus regimes de sentido, Landowski (2014: 80) traz um esquema elíptico, inspirado no quadrado semiótico, para mostrar que os modos de interações não são estanques, mas dinâmicos, e podem seguir dois percursos: primeiro, da programação ao acidente, passando pelo ajustamento; ou, segundo, do acidente à programação, passando pela manipulação. Entre os regimes da programação e da manipulação, se constrói a dêixis (ou constelação) da prudência e, do lado oposto, entre os regimes do acidente e do ajustamento, a dêixis da aventura. 


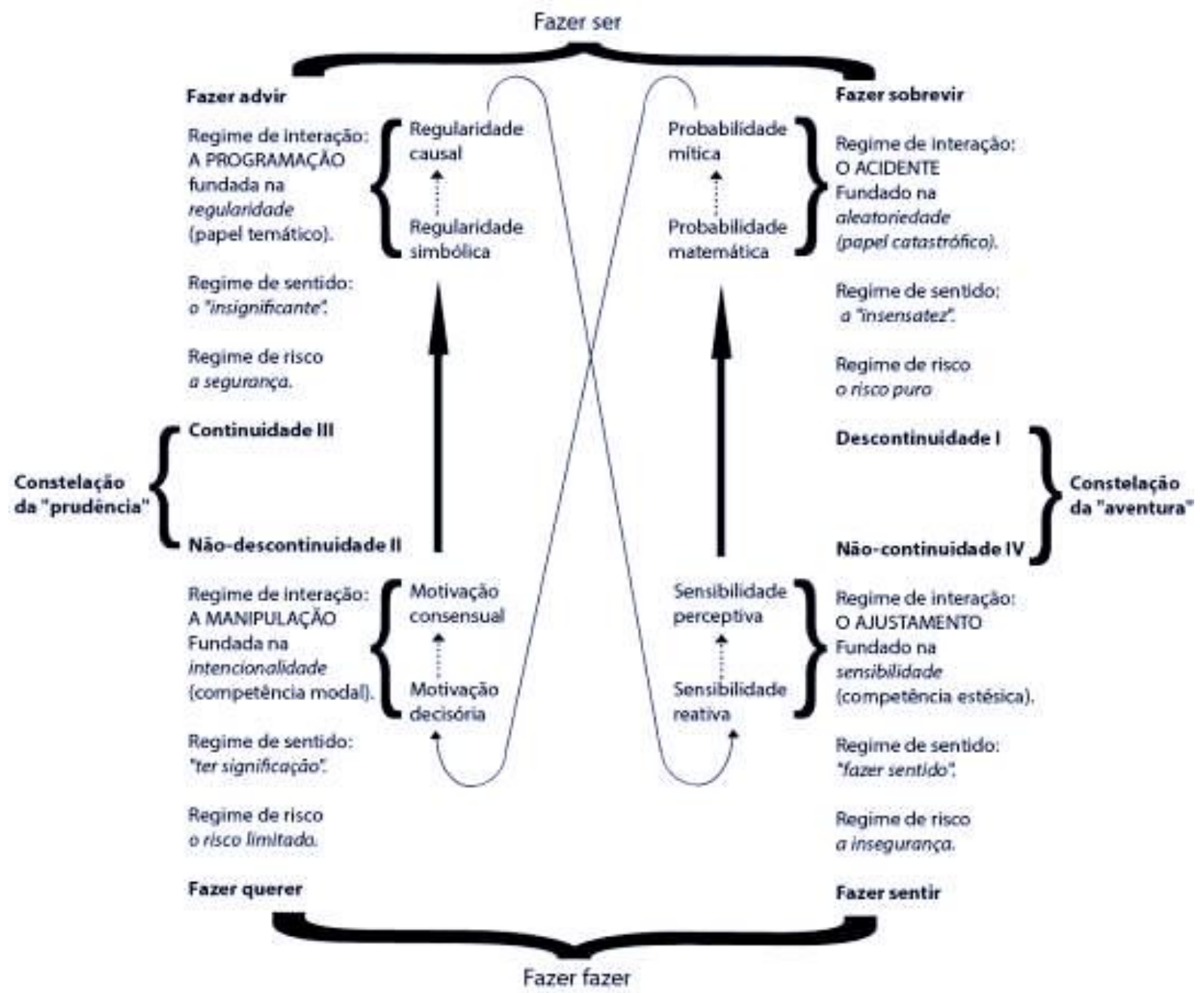

Figura 4 - Diagrama Regimes de Interação

Fonte: Landowski (2014), p. 80

Tem-se, assim, uma sintaxe das interações, a ser observada conforme objetos e situações de análise, que aplicaremos mais especificamente nesta tese no final do capítulo 3. Antes de encerrarmos este item, queremos ressaltar que se pode, ainda, pensar que as práticas pedagógicas diversas espelham de algum modo os regimes de interação. 0 behaviorismo, ou comportamentalismo, de Skinner, opera quase que exclusivamente no regime da programação: ao estímulo $\mathrm{X}$ corresponde a resposta $\mathrm{Y}$. Por exemplo, quando um aluno levanta a mão, o professor Ihe dá a palavra; quando toca o sinal, o aluno pode sair da sala. O construtivismo, de origem piagetiana, para o qual o aluno constrói o próprio conhecimento em seu tempo e o professor o auxilia, aproximar-se-ia do ajustamento, algumas 
vezes quase em direção ao acidente, pois o aluno traria as questões, de acordo com sua própria lógica, e o professor teria que lidar com elas, tentando ajustar sua sensibilidade ao que foi indagado. A interação por quase-acidente é pensada para momentos em que as coisas saíssem completamente do esperado. Para o cognitivismo, o regime de interação parece pender do ajustamento em direção à manipulação, pois o professor apresenta um conteúdo e o vai ajustando às questões do aluno, mas também conduzindo (manipulando) suas descobertas, ajudando a Ihes dar sentido. A pedagogia mais clássica, mais tradicional, opera entre o regime da programação e o da manipulação - na constelação da prudência -, pois há um currículo a ser cumprido e cabe ao professor encontrar o melhor modo de fazer o aluno saber.

Socialmente e, como consequência, também pedagogicamente, uma vez que a área da educação está contida no conjunto que se entende como sociedade, são mais bem aceitos os regimes da manipulação e do ajustamento. Trata-se justamente dos que apresentam um regime de sentido significativo, "ter significação" para a manipulação e "fazer sentido" para o ajustamento (um fazer conjunto, diga-se), em oposição ao "insensato" do acidente e do "insignificante" da programação (ver o diagrama reproduzido acima). São também esses dois regimes que apresentam a concepção de risco no matiz mais equilibrado, mediano, de uma escala que tem por extremos o "risco puro" (acidente) e a ausência de risco, a "segurança" (da programação). Além disso, esses dois regimes apresentam uma concepção do outro como um sujeito dotado de um querer. Seja esse sujeito um pouco mais manipulável, cujo querer, por conta disso, será considerado na medida em que interesse ao destinador para levá-lo a um fazer, seja esse sujeito mais ajustável, cujo querer esteja colocado no mesmo patamar de importância do querer do destinador. Em ambos os casos, tem-se uma relação entre sujeitos considerados em grau mais ou menos igualitário. Conclui-se, assim, que esses dois regimes configuram a base das relações democráticas, as que buscamos. 


\subsection{Sobre a enunciação}

A enunciação ocupa um lugar central nos estudos discursivos: trata-se do lugar a partir do qual se pode observar o discurso acontecendo. De acordo com o Dicionário de Semiótica (GREIMAS e COURTÉS, s/d [1979]: 145-148), a enunciação é o pressuposto lógico do enunciado, lugar de exercício da competência semiótica e, ao mesmo tempo, lugar de instauração do sujeito (da enunciação). O enunciado pode ser considerado como o resultado alcançado pela enunciação, que permitirá que ela seja reconstruída por meio de operações de catálise. Também se define enunciação como sendo a instância de mediação entre as virtualidades da língua e a atualização do enunciado, a instância de passagem entre a competência e a perfórmance linguísticas, nos moldes do que Saussure concebeu como como a passagem da langue à parole, ou seja, a transformação entre o que é social e abstrato para o que é individual e concreto.

Para compreender onde ela se situa para a teoria semiótica, recorremos a Diana Barros, que nos diz, na introdução de seu livro Teoria do Discurso Fundamentos Semióticos (2001: 5), que a enunciação tem um duplo papel de fazer a mediação linguística entre, de um lado, as estruturas narrativas e as estruturas discursivas e, de outro, o texto com suas condições sócio-históricas de produção e de recepção.

Se a significação nasce da variação, como propuseram Barthes (1964 e 1966) e Greimas (1966) 22, é da relação entre a invariante do sistema e a variação social que surge o sentido do discurso. A articulação do discurso com a formação social não é, por conseguinte, fortuita e ocasional ou secundária e acessória. (ibid.: 4)

Esse duplo papel da enunciação no texto evidencia sua função de ligação entre a imanência do texto e sua transcendência, entre aquilo que lhe é interno e o que lhe é exterior, "o mundo", que, para a semiótica, só pode ser apreendido por meio de outros textos. Isso também quer dizer que a enunciação opera entre o que está em modo de existência virtual e

\footnotetext{
22 BARTHES, Roland. (1964) Élements de sémiologie. Paris, Seuil. BARTHES, Roland. (1966) Introduction à l'analyse structural du récit. Communications. Paris, Seuil (16). GREIMAS, Algirdas Julien. (1966) Sémantique structurale. Paris, Larousse.
} 
o realizado, o que quer dizer que se vai da estrutura para o acontecimento discursivo (FIORIN, 2020: 133).

É apenas a partir das ideias de Émile Benveniste, difundidas no fim dos anos 1960, início dos anos 70, que se tornou possível inserir os estudos sobre a enunciação nos parâmetros da exigência de se permanecer na imanência do texto. Para os estruturalistas e sua ciência assentada no rigor da imanência, tudo deveria estar materializado na linguagem, objetivamente. Seu objeto só podia ser concebido como um sistema de relações internas do qual se visava apreender a organização. Assim, era necessário deixar de fora tudo o que se considerava como seu exterior, aí incluídas as manifestações da subjetividade, que se julgavam poder ser apreendidas, até então, apenas a partir de um ponto de vista psicológico ou ontológico. Benveniste, no entanto, "insere o homem na língua", ao dizer que ele se constitui pela linguagem e que nunca se pode encontrá-lo separado dela.

É na linguagem e pela linguagem que o homem se constitui como sujeito; porque só a linguagem fundamenta na realidade, na sua realidade que é a do ser, o conceito de "ego". (BENVENISTE, 2005: 286)

Acrescenta que são os pronomes pessoais, eu e tu, em alternância, que instituem o homem na língua, por não remeterem "nem a um conceito nem a um indivíduo" (ibid.: 288). O eu se refere ao locutor, em seu ato de discurso individual, no qual ele só pode ser identificado por meio daquele uso, naquele momento singular. A linguagem só é possível porque cada locutor se coloca como sujeito, assumindo um eu no discurso e, ao assumir um eu, o outro é assumido como um tu. Se o sujeito se encontra dentro do discurso, ele passa a ser passível de ser encontrado na estrutura, depreensível de sua realização no enunciado. Além disso, "a realidade à qual ele remete é a realidade do discurso" (ibid., idem), o que explicita que os estudos desse eu discursivo se dão dentro dos limites do texto.

Em um segundo eixo de seu pensamento (tomando-se como o primeiro a (inter)subjetividade na linguagem, conforme Flores e Teixeira, 2005: 35), Benveniste irá conceber o aparelho formal da enunciação, para o qual o sistema de referenciação é um elemento constitutivo da língua e o centro da referência passa a ser o sujeito e sua enunciação. A partir do sujeito que enuncia, tem-se a referência de pessoa e, com ela, as 
referências de tempo e de lugar da enunciação: o ego, hic e nunc (eu, aqui e agora), que instauram as categorias de pessoa, espaço e tempo para a referenciação do discurso.

Ao demonstrar que o fundamento da subjetividade está no fundamento da língua e que o sujeito se encontra dentro do discurso, Benveniste demonstra que ele é passível de ser estudado na estrutura, depreensível de sua realização no enunciado. Desse modo, os estudos semióticos se permitem passar a incluir o sujeito no discurso, o que leva aos estudos da enunciação.

A enunciação, no entanto, é da ordem da pressuposição, inapreensível em si mesma. Resta, portanto, ao analista do discurso investigar o enunciado. Para reconstituí-lo, Fiorin (2002: 32) aponta três questões, em estudos que adentram o campo da linguística: (a) a das competências necessárias para a produção de um enunciado; (b) a da ética da informação e (c) a do acordo fiduciário entre enunciador e enunciatário.

Sobre as competências, são necessárias as competências linguísticas (conhecimento da gramática da língua, léxico, sistemas fonológico, morfológico e sintático); a competência discursiva, na qual está contida a capacidade do sujeito de manejar a sintaxe e a semântica discursivas, bem como os mecanismos argumentativos da língua; a competência textual, para se saber utilizar a semiótica-objeto na qual o discurso será veiculado (texto verbal, cinema etc.); a competência interdiscursiva, que diz respeito à heterogeneidade constitutiva do discurso; competência intertextual, da relação entre os diferentes textos; a competência pragmática, referente aos valores ilocutórios dos enunciados; e, por fim, a competência situacional, que diz respeito ao conhecimento da situação comunicacional e dos parceiros que nela interagem. Tanto enunciador quanto enunciatário precisam estar de posse dessas competências e quanto maior a intersecção entre eles, melhor será a compreensão dos enunciados produzidos. Há também a importância de conhecimentos culturais ou ideológicos contidos na competência interdiscursiva. No caso do plano de aula disponível online, o fato de o enunciador se colocar como um professor (na grande maioria dos planos) que se dirige a um enunciatário também professor já aumenta esse campo de intersecção entre eles, facilitando, por assim dizer, a compreensão. 
Sobre a ética da informação, Fiorin (idem: 34) recorre a Kerbrat-Orecchioni (198023) para trazer o que a cultura consideraria "uma troca verbal honesta". São elas a lei da informatividade, que exige que se traga a uma conversação informações que o enunciatário desconheça, e a lei da exaustividade, segundo a qual se deve colocar, em uma troca verbal, o máximo de informatividade que houver - como quando se quebra um objeto, não se pode dizer que apenas se o deixou cair.

Por último, tem-se que é necessário o estabelecimento de uma convenção de confiança entre enunciador e enunciatário para que se estabeleça o estatuto veridictório do texto. É sob esse contrato que se estabelece se o texto deve ser considerado do ponto de vista da verdade e da realidade e se os enunciados devem ser entendidos do modo como foram ditos ou de algum outro modo, como na ironia, em que se deve entender o oposto. Esse contrato de fidúcia é imprescindível de ser estabelecido em sala de aula com o professor como alguém que produz enunciados com valor de verdade. Quando, como se tem visto ultimamente, uma sociedade acusa esse professor de "ideologia", palavra que tem sido deformada para querer significar um conjunto de ideias que visam a convencer os alunos para submetê-los à imposição autoritária de ideais pouco democráticos, ela quebra um contrato de confiança que deveria ser construído entre professor e aluno e assim dificulta, ou mesmo impossibilita, o desenvolvimento de relações saudáveis de ensino-aprendizagem. Voltaremos ao contrato de veridicção e sua importância para falarmos do sujeito da enunciação logo mais à frente e também posteriormente, no capítulo 4.

Estabelecido o modo de apreender-se o ato enunciativo, Greimas e Courtés (s/d [1979]) concebem que o mecanismo de instauração de pessoa, espaço e tempo da enunciação no enunciado são as operações de debreagem e embreagem. Além disso, o mesmo sujeito da enunciação que irá instituir as categorias no discurso também irá povoá-lo de figuras e temas que remetem ao mundo real, para assim construir a discursivização. A semiótica greimasiana organiza a investigação do enunciado abrindo dois flancos de investigação: de um lado a sintaxe discursiva; de outro, a semântica discursiva.

\footnotetext{
${ }^{23}$ KERBRAT-ORECCHIONI, Catherine. L'énonciation. De la subjectivité dans le langage. Paris, Armand Colin, 1980.
} 


\subsubsection{Sintaxe discursiva}

$\mathrm{Na}$ sintaxe discursiva analisam-se os aspectos de projeções da enunciação no enunciado e das relações entre enunciador e enunciatário. Trata-se da observação dos mecanismos de construção enunciativa. Eles estão ligados entre si e "[...] confundem-se muitas vezes e as diferentes projeções da enunciação explicam-se, em última instância, como procedimentos utilizados pelo enunciador para levar o enunciatário a crer e a fazer" (BARROS, 2001: 73).

A apreensão das marcas da enunciação no enunciado é feita por meio de dois mecanismos: a debreagem e a embreagem. Para o Dicionário de Semiótica (GREIMAS e COURTÉS, s/d [1979]: 95), a debreagem é a operação pela qual a enunciação "disjunge e projeta para fora de si, no ato de linguagem e com vistas à manifestação", as categorias de pessoa, espaço e tempo. O momento em que isso é feito é chamado de discursivização ("ato de linguagem", no Dicionário), que também é o nome dado ao mecanismo de criação da pessoa, tempo e espaço da enunciação e, ao mesmo tempo, da representação actancial, espacial e temporal do enunciado (BARROS, 2001; FIORIN, 2002). Como coloca Fiorin (2002: 43):

Na medida em que, como mostra Benveniste, a constituição da categoria de pessoa é essencial para a constituição do discurso e o eu está inserido num tempo e num espaço, a debreagem é um elemento fundamental do ato constitutivo do enunciado e, dado que a enunciação é a instância linguística pressuposta pelo enunciado, contribui também para articular a própria instância da enunciação.

Assim, tem-se a debreagem actancial, que consiste na disjunção de um sujeito da enunciação que projeta no enunciado um não-eu, a debreagem temporal, que projeta um não-agora distinto do tempo da enunciação e a debreagem espacial, que opõe o lugar da enunciação a um não-aqui (GREIMAS E COURTES, s/d [1979]: 95).

A embreagem, por sua vez, é o nome que se dá ao efeito de retorno à enunciação, produzido pela suspensão da oposição entre certos termos da categoria de pessoa, espaço, tempo. Não há embreagem sem uma debreagem que lhe seja anterior, da qual se podem encontrar marcas no enunciado (ibid.: 140) e, do mesmo modo que a debreagem, ela também 
se aplica às categorias de pessoa, espaço e tempo. O Dicionário de Semiótica também traz a ressalva de que não é possível conceber a embreagem total, uma vez que isso equivaleria a apagar todas as marcas do discurso, do mesmo modo, acrescentam Greimas e Courtes (s/d [1979]: 141), que não há segredo sem que haja, de alguma maneira, alguma desconfiança de sua existência.

Debreagem e embreagem, actanciais, espaciais ou temporais, podem ser de dois tipos. A debreagem é enunciativa quando se projeta como um eu-aqui-agora no enunciado, e enunciva quando se projeta no enunciado um ele-lá-então. Para a embreagem, diz-se que é enunciativa quando o termo embreante (o enunciado produzido) é enunciativo; e quando o termo embreante for enuncivo, ela recebe a mesma denominação. Essas operações discursivas resultam de escolhas do sujeito da enunciação que, desse modo, cria efeitos de sentido. Para o sistema enunciativo tem-se, principalmente, um efeito de sentido de aproximação entre enunciador e enunciatário, porque remete à subjetividade, projetando no enunciado um eu e todo o sistema de dêiticos em seu entorno. O sistema enuncivo, por sua vez, provoca o efeito de objetividade, e consequente distanciamento, ao utilizar-se do ele, não-pessoa, o então, que é o não-agora, e o lá, que não é aqui, ou seja, distantes no tempo e no espaço.

\subsubsection{As marcas de pessoa no enunciado}

O sujeito da enunciação nunca é apreensível e o "eu" que se encontra no texto é sempre um simulacro, que pode ser percebido apenas por meio de sua realização no enunciado (GREIMAS, 1974). Como continua Greimas nesse mesmo artigo, "Os diferentes eu que vocês encontram nos discursos são eu já falados, e não eu que falam”. Dessa constatação decorre a impossibilidade de apreensão do enunciador, porque se entraria no campo ontológico, filosófico. A teoria semiótica institui que o sujeito da enunciação está sempre implícito e pressuposto.

Para apreender esse sujeito, recorre-se à operação de debreagem, que mostra o modo como esse enunciador se projeta no enunciado. Isso se dá em três níveis. O primeiro deles é 
o da enunciação implícita, no qual se toma um enunciador que se dirige a um enunciatário, mas nenhum deles está mostrado no enunciado. Diz-se que estão implícitos porque são inapreensíveis a não ser pelo simulacro que se apresenta. É desse modo que se resolve a questão, outrora tão debatida, mas que hoje constitui um ponto pacífico, de que por meio do texto não se apreende o autor ou "o que o autor quis dizer", mas apenas o que efetivamente está discursivizado, realizado no texto. Fala-se, como coloca Fiorin (2002: 65), no "autor implícito", enunciador, e no "leitor implícito" do texto, o enunciatário. O segundo nível é o do narrador e do narratário, que também podem ser explícitos, se mostrados no texto - como um narrador que diz eu ou que emite opiniões sobre os personagens, ou um narratário que é interpelado pelo narrador - ou implícitos, que no entanto se sabe presentes porque desempenham funções. O terceiro nível é quando o narrador dá a voz a um actante do enunciado, que dá origem ao que se chama debreagem interna ou debreagem de segundo grau. Esse fenômeno é bastante observado na literatura, que é quando um actante já debreado torna-se instância enunciativa e dá a palavra a um outro actante: quando um narrador dá a voz a um personagem que irá apresentar sua voz no texto. Também pode ser encontrado em reportagens de jornal, quando se dá voz, por exemplo, a testemunhas de determinado evento, ancorando a enunciação a um referente do mundo real e criando, assim, um efeito de verossimilhança. Ele é encontrado também no plano de aula online, como veremos nas análises.

\subsubsection{As marcas de tempo no enunciado}

De modo análogo ao eu que se projeta no texto como um simulacro, o tempo da enunciação também precisa ser concebido não como o tempo que se percebe no mundo, o tempo cronológico, mas de modo distinto: trata-se de um tempo linguístico. Fiorin (2002: 142) nos traz, a partir das considerações de Benveniste, que esse tempo linguístico liga-se intrinsecamente ao tempo da fala, que é definido e ordenado a partir do discurso, em função de um agora gerado pelo ato de linguagem. Assim, tem-se o momento da enunciação e a necessidade de organizar os acontecimentos - estados e transformações - narrados no texto a partir dele. Dessa combinação desenvolvem-se dois sistemas linguísticos: um enunciativo, 
que gira em torno do tempo do discurso produzir o efeito de ser concomitante ao tempo da enunciação, e um enuncivo, no qual a ilusão é de não-concomitância entre essas duas temporalidades e, por isso, instala-se um momento de referência temporal no enunciado a partir do qual se desenvolverá o discurso.

\section{O Sistema Temporal ENUNCIAÇÃO}

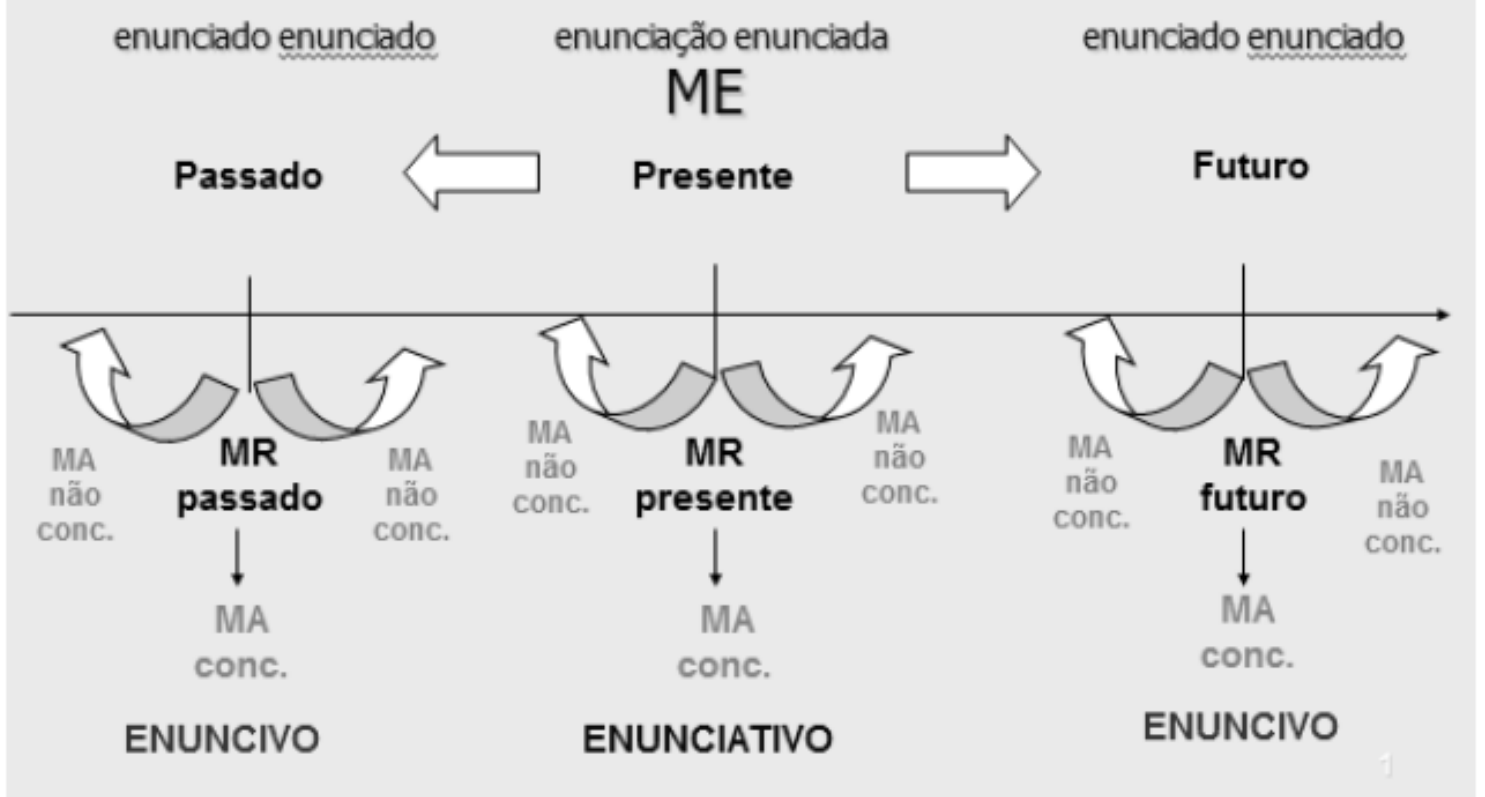

Fonte: MOREIRA, 2016, p. 43.

Aproveitamos o esquema elaborado por Renata Moreira (2016), baseado nos estudos de Fiorin (2002), para ilustrar o sistema temporal da enunciação. Primeiramente, note-se que "Enunciação" está acima, sozinha, pressuposta a todo o esquema que segue. Esse esquema é perceptível (apenas) no enunciado. Assim, tem-se: (ME) referindo-se ao momento da enunciação; (MR) como momento de referência, que pode ser anterior, no caso do passado, ou posterior, para o futuro; e (MA) refere-se ao momento do acontecimento, concomitante ou não concomitante ao momento de referência. Mostram-se, no centro, o sistema enunciativo, que se constrói como concomitante à enunciação, no tempo presente, e os dois tempos enuncivos, não concomitantes ao momento da enunciação. São sempre efeitos de sentido. O sujeito da enunciação escolhe se situará seu discurso a partir desse agora, 
produzindo uma enunciação enunciada, e aí operando no eixo temporal as debreagens enunciativas nas quais constrói o tempo linguístico em torno desse eixo; ou se situará seu discurso em um momento não-agora, anterior ou posterior, a partir do qual se constroem seu discurso e os efeitos de sentido do sistema enuncivo que quer gerar. Notemos que a noção de concomitante e não concomitante são centrais para o entendimento do sistema temporal da enunciação. Essas escolhas desvelam estratégias discursivas que visam à criação de efeitos de sentido que levem à persuasão e à interação comunicativa entre enunciador e enunciatário.

Para as análises dos planos de aula online, a observação do sistema temporal teve grande importância e mostrou uma característica bastante singular desse gênero textual. Enquanto a enunciação constrói-se como para um manual de instruções ou uma receita, o que nos traria um sistema enunciativo com o uso do presente e o tipo textual injuntivo, integra-se a ele o tempo da aula, que se projeta no futuro e que demanda, por esse motivo, uma adoção de estratégia de construção desse simulacro da aula no futuro planejado, prenunciado.

\subsubsection{As marcas de espaço no enunciado}

Greimas e Courtés (s/d [1979]: 98) falam que ao expulsar da instância da enunciação o não-aqui da categoria espacial lançam-se os fundamentos tanto do espaço "objetivo" (aspas dos autores) do enunciado quanto o espaço original da enunciação, que só pode ser reconhecido como pressuposição tópica. Fiorin (2002) clareia essa questão ao tomar por base o que Benveniste faz com o tempo na língua, a distinção entre tempo cronológico e tempo linguístico e, a partir dessa ideia, apresenta um estudo sobre o espaço na enunciação a partir da distinção entre espaço tópico e espaço linguístico.

O espaço linguístico organiza-se a partir do hic, lugar do ego. Do mesmo modo que "eu é quem diz eu", aqui determina o espaço onde está aquele que enuncia. Assim, todos os objetos localizam-se no mundo criado pela enunciação a partir do enunciador, constituído como centro e ponto de referência. A debreagem enunciativa, portanto, ocorre quando o ponto de referência é o espaço do enunciador, como em "Roubaram a bolsa de uma mulher 
em um bar aqui perto"24, e a debreagem enunciva quando o ponto de referência é um algures / alhures instalado no enunciado, como em "[...] professor deverá levá-los ao laboratório de informática para que pesquisem [...]" (plano de aula 03).

O espaço tópico marca nas línguas a emergência da descontinuidade na continuidade, o que quer dizer que traz o ponto onde se inicia a apreensão espacial. Esse espaço pode ser determinado seja em relação ao enunciador (por exemplo "atrás de mim"), seja em relação a um ponto de referência inscrito no enunciado (por exemplo "atrás da casa"). Se nenhum actante estiver presente para servir como ponto de referência, é preciso que esse ponto seja construído no enunciado (por exemplo "do lado direito da igreja, olhando de frente para ela", conf. Fiorin, 2002).

\subsubsection{Semântica discursiva}

Na semântica discursiva tem-se a descrição ou explicação da conversão do percurso narrativo em percurso temático e o posterior revestimento figurativo dos actantes e dos valores que haviam sido colocados no nível narrativo, de modo que se criem efeitos de realidade por meio do discurso. Esse trabalho também é feito por meio da sintaxe discursiva e tem na figurativização uma estratégia de fazer-crer, de construção da verdade e do contrato fiduciário entre enunciador e enunciatário (BARROS, 2001: 117-8).

A tematização e a figurativização são dois níveis de concretização do sentido, o tema remetendo ao mais abstrato e a figura, ao mais concreto. Subjacente às figuras e ao percurso figurativo que se encontra no texto, sempre há temas e um (ou, por vezes, mais de um) percurso temático. As distinções não são estanques, não há textos exclusivamente temáticos ou figurativos, mas mais ou menos temáticos ou figurativos.

A enunciação, como instância de produção do discurso, [...] está sendo retomada como uma espécie de depósito de figuras, a partir de que o sujeito da enunciação especifica e concretiza os temas abstratos e reveste semanticamente a narrativa. O depósito forma-se no tempo e no espaço,

\footnotetext{
${ }^{24}$ Exemplo retirado de Fiorin (2002), p. 265.
} 
historicamente, e o discurso figurativizado, graças a seu dispositivo de figuras, relaciona-se com o 'extradiscursivo' e constitui-se ideologicamente. As figuras são, por excelência, o lugar do ideológico no discurso. (ibid., 1234 , grifos no original)

Interessante notar que quando Diana Barros nomeia a enunciação como depósito de figuras, tomando de empréstimo essa metáfora do Dicionário de Semiótica (s/d [1979]: 147), ela está, ao mesmo tempo, exemplificando qual o papel que uma figura desempenha no discurso: criar uma imagem (que pode ser mais ou menos concreta) que permite ao enunciatário "visualizar" o que o enunciador está dizendo. Trata-se de uma estratégia escolhida pelo sujeito da enunciação, que dispõe de estratégias discursivas e de figuras dentre as quais escolherá aquelas que surtirão melhor efeito junto ao enunciatário visado por seu discurso. Teria sido possível, por exemplo, que se tivesse chamado a enunciação de coleção de figuras ou prateleira de figuras, mas essa escolha teria engendrado outro tipo de sentido para o enunciatário. Ao optar por "depósito", o enunciador inclui um traço (ou um sema, para utilizar a linguagem da semântica estrutural) de maior abundância do que uma coleção, e de maior variedade e organização menos visual e menos categorizada do que a de uma prateleira. Um depósito parece comportar um pouco mais de caos, de desorganização e também de possibilidades e, portanto, maior riqueza de sentidos do que uma coleção ou prateleira - e, ao evocar essa relação entre depósito e os sentidos que se atribuem a ele, estamos, ao mesmo tempo, indicando uma concepção que trazemos como conhecimento de mundo enquanto enunciatários do discurso, e ajudando a construir o seu sentido.

Note-se que, ao evocar as figuras do mundo natural: depósito, coleção e prateleira, convoca-se, por meio da linguagem, elementos que pertençam a um universo comum entre enunciador e enunciatário. Tem-se então que a figuratividade se coloca como o lugar de estabelecimento das relações de construção do sujeito da enunciação, este concebido como a soma de enunciador e enunciatário e suas relações. Trata-se, segundo Denis Bertrand (2003: 154), de um conceito estendido tanto a linguagens verbais quanto não verbais e que designa a propriedade que elas têm de "restituir parcialmente significações análogas às de nossas experiências perceptivas mais concretas". A figuratividade, diz Bertrand, está enraizada na teoria semiótica do sentido e considera de maneira ampla os fenômenos semânticos e as realizações culturais que se ligam aos processos de figurativização. A combinação e a 
recorrência de figuras ou de temas em um texto denomina-se isotopia, responsável pelo desenvolvimento semântico do discurso e pela criação de um efeito de permanência de um dado efeito de sentido ao longo dele (BERTRAND, 2003: 420). A partir das isotopias figurativas - que revestem atores, espaço e tempo - formam-se as isotopias temáticas, que são mais abstratas e se estabelecem pela leitura.

\subsubsection{Relações entre enunciador e enunciatário}

A teoria semiótica discursiva determina que o sujeito da enunciação resulta da junção de enunciador e enunciatário, pois ambos são responsáveis pela produção do sentido de um enunciado. O enunciador se coloca como destinador, responsável pelos valores do discurso e por fazer o enunciatário, seu destinatário, a crer e a fazer. Tem-se, assim, de uma parte, um fazer persuasivo, ao qual corresponderá um fazer interpretativo de outra parte. Essa relação de manipulação visa ao estabelecimento de um contrato veridictório, no qual o destinador irá propor os valores que circulam no discurso como um jogo entre ser e parecer, que podem ser tomados como verdade (aquilo que é e parece ser), mentira (que não é, mas parece), segredo (é, mas não parece) ou falsidade ou ilusão (não é e não parece). A verdade e a falsidade do discurso dependem dessa construção interna do texto, mas também do gênero discursivo, da cultura e da sociedade em que se insere o discurso. Pode-se, assim, dizer que há contratos anteriores que circulam, cultural ou ideologicamente estabelecidos, para que se institua um contrato de verdade e que a verdade é uma construção discursiva, um efeito de sentido engendrado pelo texto. Um discurso é interpretado como verdadeiro se ele parece verdadeiro a partir do contrato de veridicção proposto e aceito.

A partir do valor de verdade estabelecido discursivamente, estabelece-se também o contrato de fidúcia, imprescindível a toda comunicação. Trata-se da relação de confiança entre enunciador e enunciatário, em que o segundo crê no que lhe é enunciado pelo primeiro. Esses dois contratos contêm muitos elementos a serem considerados. Quando pensamos em sintaxe discursiva, o estabelecimento do tempo da narrativa pelo enunciador precisa ser aceito pelo enunciatário, idem para o espaço e para o éthos do enunciador. Quando se toma 
a semântica discursiva como campo de análise, observa-se, por exemplo, que a construção de uma isotopia por meio de figuras trazidas ao texto precisa ser aceita como um valor, eufórico ou disfórico, pelo enunciatário.

Para se observar a relação entre enunciador e enunciatário nos discursos na internet, dos quais também se ocupa esta pesquisa, Barros (2015) nos traz que neles se encontram efeitos de sentido de grande quantidade de saber acumulada e de interatividade acentuada, o que induz os discursos na internet a não só parecerem verdadeiros, mas, mais ainda, parecerem desmascarar a mentira ou então revelar um segredo, provocando no enunciatário uma maior adesão. Essa interatividade intensa faz ainda com que o enunciatário do discurso se sinta como autor dos discursos - o que se intensifica por ele ter o poder de propagá-los como se fossem seus, uma vez que, na origem, a autoria desses discursos não possui uma identidade definida para além do uso da enunciatividade empregada e que os meios de divulgação não apenas permitem mas também facilitam essa reverberação do discurso.

Coloca-se também como relevante o problema da falta de controle sobre qual auditório será atingido por determinado discurso. Utilizamos auditório aqui como empréstimo da retórica para significar um enunciatário coletivo visado por um enunciador. Um discurso sempre é produzido visando a um enunciatário, que dele saberá extrair os valores que lhe são endereçados. No entanto, ao ser disponibilizado pela internet, há uma mudança no modo como se pode prever esse auditório, envolvendo as questões de público e privado e também a característica do discurso na internet de ser dotado de grande extensão comunicacional (BARROS, 2015). Um discurso pensado para persuadir um enunciatário que compartilhe das mesmas ideias políticas, por exemplo, pode chegar a sujeitos que sejam partidários de um espectro oposto e que, portanto, não estavam previstos como enunciatários, o que faz com que o efeito de verdade de um discurso não seja aquele que havia sido planejado pelo enunciador. O discurso que circulava no mundo físico, offline, podia prever muito melhor seu enunciatário do que um discurso que está disponibilizado na rede mundial de computadores. Nos termos colocados por Rastier, em Semiótica da Transmissão (2015), trata-se da diferença entre o endereçamento e a destinação, da qual o sujeito da enunciação do discurso da internet não se apercebe. No endereçamento o enunciador se dirige a um enunciatário específico, como, no teatro, quando um personagem fala com outro 
e, no entanto, a destinação da fala desse personagem é, na verdade, o público. Em nosso objeto de análise, o plano de aula disponível online, percebem-se manipulações que se endereçam ao aluno, mas cuja destinação visa o professor, que deve ser manipulado antes para ser levado a crer que deve (ou pode ou quer) estender aquela manipulação ao aluno, destinatário da aula.

\subsection{Sobre a semiótica tensiva}

Em contraposição (ou complementaridade?) ao modelo de análise narrativa baseado na descontinuidade criado por Greimas, no qual o sentido era buscado na ruptura, na transformação operada entre um sujeito e sua relação de junção com um objeto, Claude Zilberberg propõe a semiótica tensiva para dar conta da apreensão do sentido por gradações observáveis e apreensíveis na continuidade, encontrando-as nas instabilidades, grandes ou pequenas. Assim, busca-se explicar as instabilidades dos fenômenos contínuos pertencentes ao universo sensível. Em nossas análises, algumas vezes, depois de verificada a estratégia discursiva utilizada pelo enunciador, destinador do plano de aula, surgiu a necessidade de verificar a foria emergente dos enunciados que foram aí construídos, para observação e apreensão da força do discurso que visa à persuasão. Essa força mostrou operar tanto sob a lógica implicativa quanto a concessiva, trazendo a necessidade de se recorrer aos estudos zilberbeguianos para essas investigações, uma vez que a semiótica greimasiana não previa o segundo tipo de operação.

Tal apreensão, outrora chamada de afetividade, ganha o nome de tensividade, que se coloca como um campo de interseção entre os eixos de intensidade, referente ao sensível, ao afeto, e de extensidade, da ordem do inteligível, do estado de coisas. É na junção dessas duas dimensões que se forma o espaço tensivo de recepção no qual as diversas grandezas têm acesso ao campo de presença do sujeito. Tem-se, então, não mais o sujeito da busca, da falta, que empreende uma ação ou que se submete a um estado de conjunção ou disjunção com um objeto valor, como nas narrativas proppianas do primeiro momento das análises 
semióticas, mas um sujeito que percebe e cujo campo de presença é invadido por valores e valências, que operam em tensão. A dimensão da intensidade é regente e a da extensidade, regida, o que significa dizer que o sensível rege o inteligível. Esses dois eixos, por sua vez, possuem duas subdimensões cada um: para a intensidade, andamento e tonicidade; para a extensidade, temporalidade e espacialidade.

As instabilidades que adentram o campo de presença são apreendidas por seus aumentos ou diminuições, ou seja, sobre os mais e os menos que atuam sobre os acentos de sentido e que são ascendentes ou descendentes. A um aumento ou uma diminuição no eixo da intensidade pode corresponder outro ou outra no da extensidade, gerando uma correlação conversa (quanto mais.... mais ou quanto menos... menos), que é de tipo implicativo; doutro modo, um aumento ou uma diminuição no eixo da intensidade ao qual corresponda seu contrário no eixo da extensidade gera uma correlação inversa (quanto mais... menos, quanto menos... mais), esta de tipo concessivo. As relações de tipo implicativo pertencem à lógica regida por um porque, como em: "ela não saiu porque chovia forte", e são da ordem do pervir, do esperado; as relações de tipo concessivo, da ordem do sobrevir, da surpresa, operam na lógica do embora: "embora chovesse forte, ela saiu.". Trata-se, aí, do inesperado.

Entre a implicação e a concessão há uma tensão, que está, segundo Zilberberg (2011: 100), "numa medida a ser determinada, no princípio da dinâmica dos discursos". A conjunção e a disjunção, para o semioticista, não são distintas e sucessivas, mas contemporâneas e tensivas, e ora se tem um programa conjuntivo prevalecendo sobre um contraprograma disjuntivo, ora o contrário (idem: 98); a implicação é definida pelo predominío do programa sobre o contraprograma e a concessão, pelo domínio do contraprograma sobre o programa. Zilberberg também nos diz que não há relações concessivas a não ser em discurso (idem: 99) e que enquanto as relações implicativas são mais neutras e generalizantes e definem em parte crenças e práticas próprias a um sistema, as relações concessivas são mais tônicas e aparecem quando as implicativas falham. As relações concessivas portam um valor de acontecimento, enquanto as implicativas levam ao exercício (ou estado).

Ao projetarem-se as coerções estruturais, do primado das relações entre os elementos, tem-se que: (a) o andamento rege a duração por correlação inversa (quanto maior a velocidade, menor a duração, do que resulta que o ser seja resultado de uma lentidão 
extrema), e a tonicidade rege a espacialidade por correlação conversa (quanto mais tônico, mais vasto o campo de desdobramento); (b) entre as subdimensões pertencentes a uma mesma dimensão a correlação é sempre conversa e dela resultam: no eixo da intensidade, o par [impactante vs. tênue]; no eixo da extensidade, o par [concentrado vs. difuso]. Esses dois pares controlam o acesso de uma grandeza ao campo de presença.

Nas duas subdimensões intensivas, o andamento e a tonicidade, e nas duas extensivas, a temporalidade e a espacialidade, tem-se que as variações e mudanças que afetam o sentido decorrem do fato de ele estar imerso no "movente", no instável e imprevisível, em suma, na foria. O termo foria está ligado à energia, à força que faz mover o discurso. A partir dela adota-se o neologismo forema para designar essa energeia para cada uma das subdimensões. São eles: a direção, a posição e o elã. A partir do cruzamento dos três foremas com as quatro subdimensões, têm-se doze pares de valências, conforme o seguinte quadro:

\begin{tabular}{|c|c|c|c|c|}
\hline dimensões & \multicolumn{2}{|c|}{ intensidade regente } & \multicolumn{2}{|c|}{ extensidade regida } \\
\hline & andamento & tonicidade & temporalidade & espacialidade \\
\hline direção & $\begin{array}{c}\text { aceleração } \\
\text { vs. } \\
\text { desaceleração }\end{array}$ & $\begin{array}{l}\text { tonificação } \\
\text { vs. } \\
\text { atonização }\end{array}$ & $\begin{array}{c}\text { foco } \\
\text { vs. } \\
\text { apreensão }\end{array}$ & $\begin{array}{c}\text { abertura } \\
\text { vs. } \\
\text { fechamento }\end{array}$ \\
\hline posição & $\begin{array}{l}\text { adiantamento } \\
\qquad v s . \\
\text { retardamento }\end{array}$ & $\begin{array}{c}\text { superioridade } \\
\text { vs. } \\
\text { inferioridade }\end{array}$ & $\begin{array}{c}\text { anterioridade } \\
\text { vs. } \\
\text { posterioridade }\end{array}$ & $\begin{array}{c}\text { exterioridade } \\
\text { vs. } \\
\text { interioridade }\end{array}$ \\
\hline elã & $\begin{array}{c}\text { rapidez } \\
\text { vs. } \\
\text { lentidão }\end{array}$ & $\begin{array}{c}\text { tonicidade } \\
\text { vs. } \\
\text { atonia }\end{array}$ & $\begin{array}{c}\text { brevidade } \\
\text { vs. } \\
\text { longevidade }\end{array}$ & $\begin{array}{c}\text { deslocamento } \\
\text { vs. } \\
\text { repouso }\end{array}$ \\
\hline
\end{tabular}

Para as análises de nosso corpus, nos foi possível observar algumas gradações na continuidade de movimentação do discurso analisado, em diferentes subdimensões que constam no quadro acima. Serão encontradas nas análises do capítulo 3 considerações quanto à abertura ou ao fechamento, a aceleração, tonicidade ou atonia na comparação entre espaços, objetivos de aula, velocidade da informação ou da aprendizagem. Trata-se de 
tentativas de observação desse movimentar-se da tensão discursiva que contribuem para a construção do sentido do fazer enunciativo que singulariza nosso objeto de análise.

O plano de aula disponível online caracteriza-se como pertencente à ordem do pervir, da ordem do esperado. Pode-se, por isso, pontuar que, inserido na lógica implicativa, mostra uma organização narrativa bastante evidente, o que se observa nas escolhas de conceitos de análise que foram aplicados no próximo capítulo. O imprevisto está contido no universo da aula, faz parte de seu sistema, mas o plano de aula, nosso objeto, se ocupa da parte previsível, porque esse é justamente o seu papel, de simulacro, da ordem do fazer acontecer essa aula, porque (bem) planejada. No entanto, as relações entre enunciador e enunciatário que se estabelecem nesse texto nem sempre se inserem nesse mesmo regime, como veremos nas análises. 


\section{Análise de planos de aula disponíveis online}

O discurso científico é moldado pela contingência. Ele propõe modelos parciais de explicação de realidade. Por isso, não chega nunca à verdade absoluta.

José Luiz FIORIN

Este capítulo destina-se às análises dos planos de aula disponíveis online, para as quais se utilizam as concepções teóricas apresentadas no capítulo 2. Primeiramente apresentamse análises individuais de cada plano de aula, segundo critérios que se apresentam na sequência. Depois, desenvolvem-se análises comparativas entre esses planos, a fim de caracterizá-los e compreendê-los. Apresentam-se, antes, a seguir, os critérios para a seleção do corpus.

\subsection{Critérios de seleção do corpus}

O primeiro critério em relação à seleção para análise de planos de aulas disponíveis no Portal do Professor ${ }^{25}$ foi a delimitação de componente curricular - Língua Portuguesa - e nível

\footnotetext{
${ }^{25}$ Site mantido pelo MEC conforme explicado na introdução e no capítulo I desta tese. http://portaldoprofessor.mec.gov.br
} 
de ensino - anos finais do ensino fundamental, mais precisamente 8 ㅇ e 9o anos. Essa escolha se justifica pelo fato de as séries finais do ensino fundamental permitirem que se façam aulas um pouco mais elaboradas, pois os alunos dessa faixa etária já são capazes de fazer abstrações de raciocínio, possuem horizonte de interesses um pouco mais amplo e têm boa proficiência de leitura, razões pelas quais os que elaboram essas aulas dispõem de mais liberdade para escolher os assuntos e as atividades que serão desenvolvidos. Ainda, preferiu-se o final do ensino fundamental ao ensino médio por se considerar que este último apresenta o conteúdo de modo mais fragmentado, primeiro porque separa o componente curricular Língua Portuguesa em Gramática, Redação e Literatura e depois porque, em muitos casos, visa mais aos exames de admissão no ensino superior do que à formação do aluno.

No início desta pesquisa, a primeira preocupação havia sido buscar nas aulas o porquê de uma delas ter despertado mais o interesse do professor do que outra, o que havia em uma aula que levava o professor a querer fazê-la em vez de querer fazer uma outra aula. Visto que o Portal contava na época com mais de quinze mil aulas e que havia mais de uma aula sobre o mesmo assunto, muitas vezes, então, não se tratava de uma questão de escolher apenas um assunto. Enxergar o corpus a partir dessa perspectiva também seria possível porque o site disponibiliza, na busca pelas aulas, filtros de classificação. Esses filtros são feitos por componente curricular, tema, unidade da federação (UF) e ordem de classificação, que são seis: relevância, ordem de publicação, mais comentadas, melhor classificadas [sic], ordem alfabética, mais acessadas.

Depois de mais de um ano aplicando esses filtros, foi possível observar que as aulas que aparecem na filtragem "relevância" ou "melhor classificadas" variavam um pouco com o tempo e não necessariamente mostravam aulas que tinham tido mais acessos ou mais estrelas de avaliação. Isso pode ser resultado de uma falha no algoritmo que ordena as aulas no site ou, ainda, de critérios que não tenham sido bem estabelecidos - não se fala no site o que quer dizer "melhor classificadas" ou a que se refere o filtro "relevância". Depois dessa constatação, a seleção de aulas a serem analisadas por este trabalho sofreu algumas mudanças a partir do que havia sido concebido originalmente - aulas mais acessadas, mais bem classificadas, com mais comentários - para se tornar uma seleção de aulas que aparecem nessas buscas de mais bem classificadas ou mais relevantes e, dentre essas aulas que apareceram no topo, foram 
escolhidas aulas de autores diferentes, originários de lugares diversos e que tratassem de assuntos variados. No resultado dessas buscas, apareciam algumas vezes aulas de um mesmo autor e também havia muitas aulas feitas por autores do Estado de Minas Gerais, o que leva à hipótese de que na época pode ter acontecido uma campanha de incentivo no Estado para que se publicassem aulas no Portal do Professor.

Assim, separamos um total de dez planos de aula que foram observados e inseridos em uma planilha para observação de seus aspectos mais gerais e de características recorrentes que pudessem identificá-los e, dentre eles, foram selecionados sete planos para análise mais minuciosa, que serão desenvolvidas a seguir. Os planos de aula analisados se encontram em anexo. No início de cada uma das análises, justificamos de modo mais específico a presença do plano no corpus.

A seguir, trazemos a figura 5 que mostra a tela por meio da qual se faz a busca por aulas no site Portal do Professor e que foi utilizada para a seleção das aulas que compõem este corpus. Depois, as duas figuras seguintes mostram o resultado da pesquisa que fizemos utilizando os seguintes critérios:

- tipo de pesquisa: Ensino Fundamental final;

- componente curricular: Língua Portuguesa;

- $\quad$ ordem de classificação: melhor classificadas.

A figura 6 mostra o resultado obtido em outubro de 2015, época de início de seleção do corpus, e a figura 7 mostra o resultado para o mesmo filtro de seleção, mas para dezembro de 2019. Pode-se verificar que os planos de aula que resultam dessa seleção permaneceram os mesmos entre o período em que iniciamos e o de finalização da coleta do corpus. 


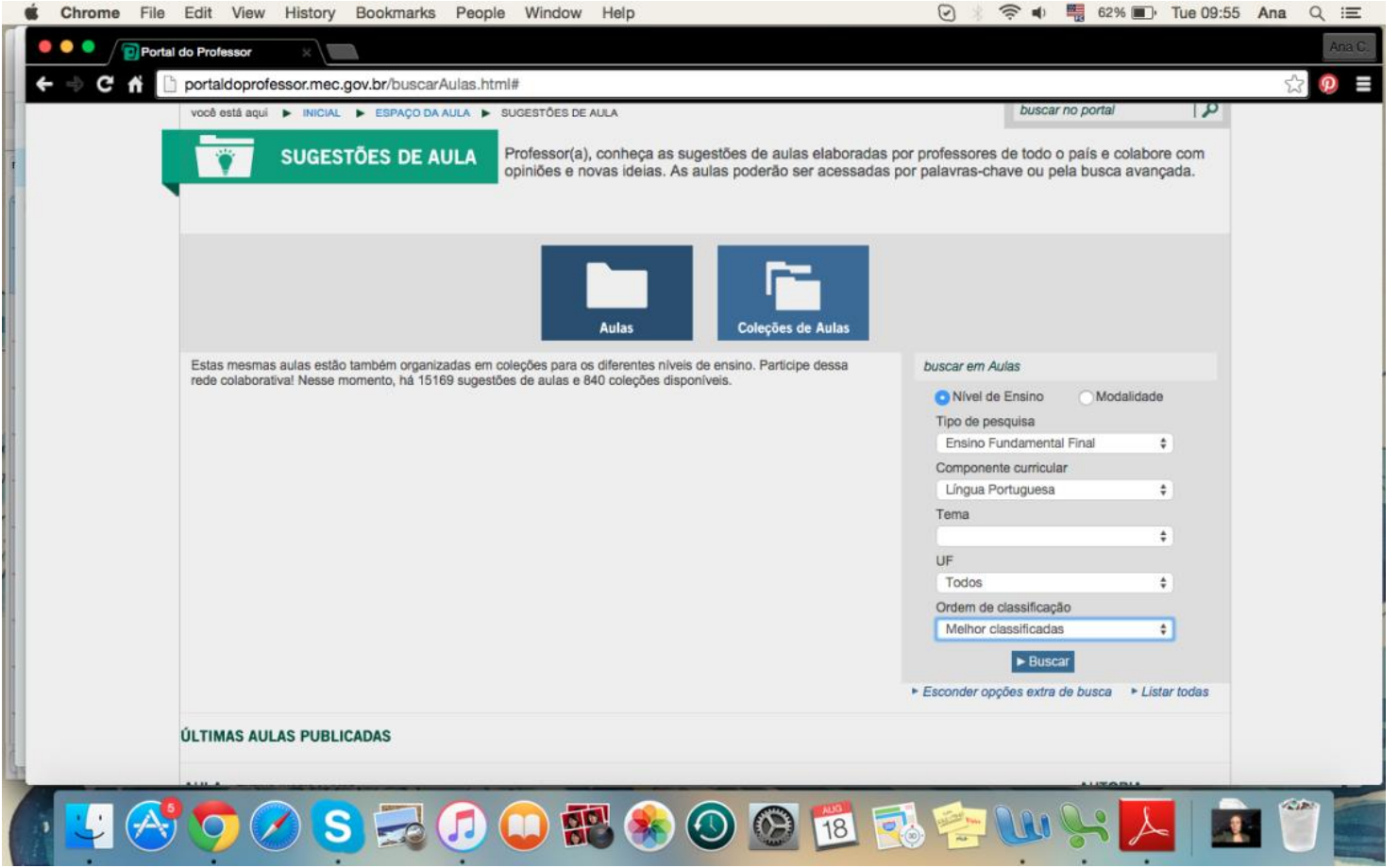

Figura 5 - print de tela de busca de aulas no Portal do Professor.

$\sqcup$ portaldoprofessor.mec.gov.br/buscarAulas.html?busca=\&tipopesquisa=1\&modalidade $=2 \&$ componente $=22 \&$ tema $=\&$ uf $=\&$ ordem $=3 \& x=36 \& y=10 \& b a=t r u e \# r$ RESULTADUS UA BUSCA

AULA

Sua busca retornou 1303 aulas para Ensino Fundamental Final | Língua Portuguesa (1.669 segundos)

$\rightarrow$ Debate deliberativo sobre Bullying

AUTORIA

Ensino Fundamental Final | Lingua Portuguesa

Ensino Fundamental Final | Pluralidade Cultural

O aluno aprenderá a organizar e analisar os dados de pesquisa, selecionando artigos e depoimentos que sejam úteis para a

apresentação do trabalho em forma de debate. Sua pesquisa deverá ser salva no blog individual criado pelo aluno para difundir o tema

24/09/2009 $\star \star \star \star \star * 10$ comentário(s) 16299 acesso(s)

- As várias facetas de Machado de Assis

Ensino Fundamental Final | Lingua Portuguesa

Conhecer vários contos de Machado de Assis; Comparar as histórias e seus entrelaces. Compartilhar historias e opiniöes sobre a

bra do autor estudado.

$24 / 10 / 2008 \star \star \star \star \star 2$ comentário(s) 3671 acesso(s)

Isso lá, é perfume?

Ensino Fundamental Final | Ciências Naturais

Ensino Fundamental Final | Lingua Portuguesa

Ensino Fundamental Final | Matemática

Ensino Médio | Química

Calcular o percentual de substâncias quimicas em misturas e soluçōes.

ROSÅNGELA FERREIRA LUZ

EM PROFa CLORI BENEDETTI DE

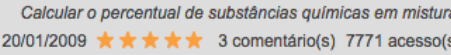

\section{- E amassaram o pára-choque}

Ensino Fundamental Final | Ciências Naturais

Ensino Fundamental Final | Lingua Portuguesa

Ensino Fundamental Final | Meio Ambiente

Ensino Médio | Química

Demonstrar aos alunos a técnica de galvanoplastia, utilizado industrialmente para proteger peças de aços da corrosão; eletrolise e

20/01/2009 $\star \star \star \star \star \star 2$ comentário(s) 7643 acesso(s)

O futurismo de Monteiro Lobato

Ensino Fundamental Final | Língua Portuguesa

Aprofundar os conhecimentos da obra de Monteiro Lobato; Comparar os fatos abordados na obra de Monteiro Lobato com a eleiçấo de Barack Obama; Discutir sobre os elementos da Fiç̧ấo Cientifica; Desenvolvimento da competéncia de argumentaçấo e de

comunicaçâa; Criar um texto de fi.

03/03/2009 $\star \star \star \star \star * 5$ comentário(s) 9069 acesso(s)

Grace Luciana Pereira

Universidade de São Paulo

SAO PAULO SP

Informação e Comunicaçấo

MARCO ANTONIO AMARAL

SECRETARIA ESTADUAL DE

EDUCAÇÃO

CURITIBA PR

Matemática

MARCO ANTONIO AMARAL SECRETARIA ESTADUAL DE
EDUCAÇAO

CURITIBA PR

Matemática

Grace Luciana Pereira

Universidade de Săo Paulo

SAO PAULO SP

Informação e Comunicaçấo

Figura 6 - print de tela de resultado para busca de aulas "melhor classificadas" no Portal do Professor em out./2015. 


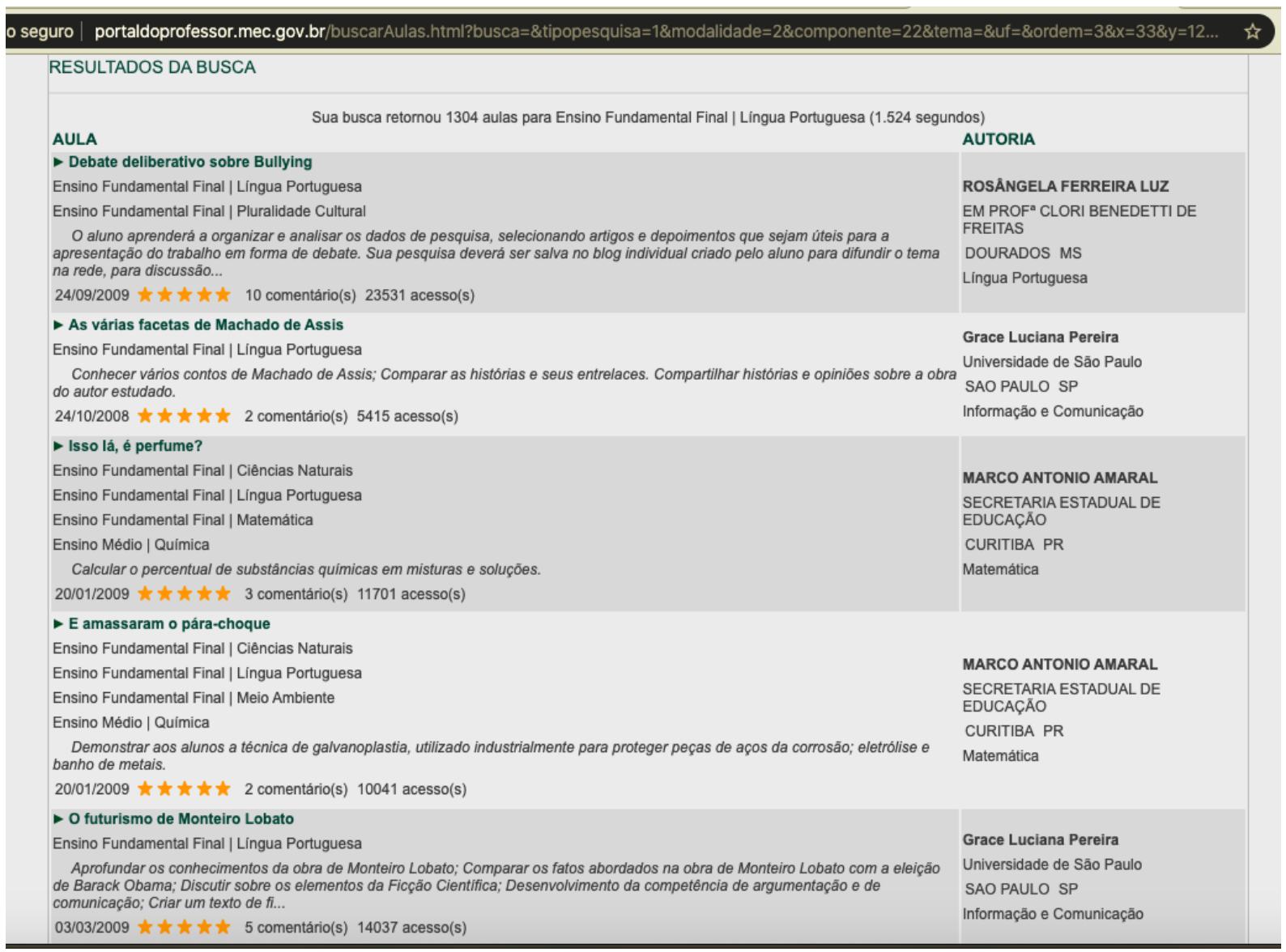

Figura 7 - print de tela de resultado para busca de aulas "melhor classificadas" no Portal do Professor em dez./2019.

Dos cinco primeiros planos de aula que aparecem como resultado nessa busca, serão analisados o primeiro, "Debate deliberativo sobre bullying" (quinta aula analisada), e o segundo, "As várias facetas de Machado de Assis" (sexta aula analisada). As aulas que aparecem em terceiro e quarto lugar são aulas de ciências que indicam a língua portuguesa como componente curricular apenas para a confecção de relatórios sobre os experimentos, por isso ficaram de fora de nossas análises. A quinta aula, "O futurismo de Monteiro Lobato", foi feita pela mesma autora da aula dois e por esse motivo, a preterimos em favor de outras para diversidade de autores na composição de nosso corpus.

A partir desses critérios e de outros que serão especificados no início de cada uma das análises, as aulas que compõem este corpus são:

1. UCA - As potencialidades do conhecimento pela navegação na Internet: uma visita ao Museu de Língua Portuguesa; 
2. Entendendo as funções da linguagem;

3. Coesão textual: o pronome na construção do texto;

4. Publicando com Cecília Meireles;

5. Debate Deliberativo sobre Bullying;

6. As várias facetas de Machado de Assis;

7. Lições de língua crítica e culta.

\subsection{Procedimentos de análise}

As análises que se apresentam a seguir desenvolveram-se, em um primeiro momento, a partir de análises piloto de quatro aulas (as quatro primeiras que se apresentam neste capítulo) que foram levadas para o exame de qualificação, em meados de 2018. A partir dessa primeira compreensão do plano de aula disponível online como um objeto passível de ser analisado discursivamente e das sugestões de ampliação e aprofundamento das questões de investigação, as análises ganharam o desenvolvimento que ora se apresenta. Das quatro análises iniciais, chegou-se às sete atuais. Nelas estão privilegiadas as apreensões das estratégias discursivas: debreagens e embreagens das categorias de pessoa, espaço e tempo e a construção de isotopias por meio do uso de figuras e temas, pelas quais se verificam os valores que circulavam nessa esfera discursiva. Também contêm observações sobre o modo de ensinar, sobre a organização do planejamento e das aulas e sobre a presença ou ausência de questões didáticas que nos pareceram relevantes a partir dos conhecimentos teóricos e empíricos que temos da esfera da educação.

Para apreender nosso objeto discursivamente, as análises apoiam-se mais fortemente no conceito da enunciação e no modo como a semiótica discursiva o analisa, sintática e semanticamente. Podemos dizer também que nossas análises buscam contemplar o objeto 
em questão a partir de mais de um ponto de vista, mas sempre dentro dos conceitos de análise da semiótica francesa, utilizando seu ferramental conforme exposto no capítulo 2.

Apresentamos a seguir as características que serão observadas e analisadas nos planos de aula disponíveis online que compõem nosso corpus. São também elas que comporão os itens de análise comparativa.

Em primeiro lugar, analisa-se a seção "objetivos da aula". Nos planos de modo individual, ela é analisada discursivamente e, depois, no item em que se faz a análise comparativa, estabelece-se um paralelo entre os objetivos propostos e o modo de avaliar a aula, a fim de se verificar em que medida se estabelece o diálogo que deveria ligá-las uma à outra. Em alguns casos, e mais fortemente na análise comparativa, utiliza-se a Taxonomia de Bloom para verificar quão tônicos são os objetivos estabelecidos para a aula. A Taxonomia de Bloom é uma classificação de objetivos de aprendizagem criada pelo psicólogo educacional norteamericano Benjamin Bloom em 1956. Trata-se de um instrumento que classifica os verbos de aprendizagem em complexidade crescente, que visa a trazer clareza para os professores sobre o desenvolvimento dos processos cognitivos para aquisição de conhecimento e que pode ser de grande auxílio no planejamento das atividades de ensino e aprendizagem. A classificação apresenta seis níveis de domínio para a aprendizagem cognitiva, que são muitas vezes apresentados em forma de uma escada, com (1) como o primeiro degrau e a subida da escada simbolizando o gradativo aumento da complexidade da apreensão do saber.

Um breve desenvolvimento sobre eles se apresenta conforme segue ${ }^{26}$ :

(1) conhecimento, "envolve a lembrança de específicos e universais, de métodos e processos, ou a lembrança de um padrão, estrutura ou cenário". (2) compreensão, "se refere a um tipo de compreensão ou apreensão tal que o indivíduo saiba o que está sendo comunicado e pode usar o material ou ideia que está sendo comunicada sem necessariamente relacioná-la a outro material ou enxergar suas implicações mais completas".

\footnotetext{
${ }^{26}$ Resumo do Vanderbilt University Center for Teaching (ARMSTRONG, s/d), utilizando trechos da obra de 1956 de Bloom e traduzido por nós. Tendo finalizado esta parte do capítulo durante o período de isolamento social por causa da pandemia de SARS-CoV2, não nos foi possível buscar o texto original de Bloom, razão pela qual recorremos a essa página do centro de ensino dessa universidade americana, que nos pareceu suficientemente informativa para os fins a que visamos.
} 
(3) aplicação, se refere ao "uso de abstrações em situações concretas ou particulares".

(4) análise, representa a "decomposição da comunicação em seus elementos constituintes ou em partes de modo que a hierarquia relativa das ideias fique clara e ou a relação entre as ideias expressas sejam explicitadas".

(5) síntese, envolve a "combinação de elementos e partes de modo que se forme um todo".

(6) avaliação, engendra "julgamentos sobre o valor do material e dos métodos para determinados propósitos" 27.

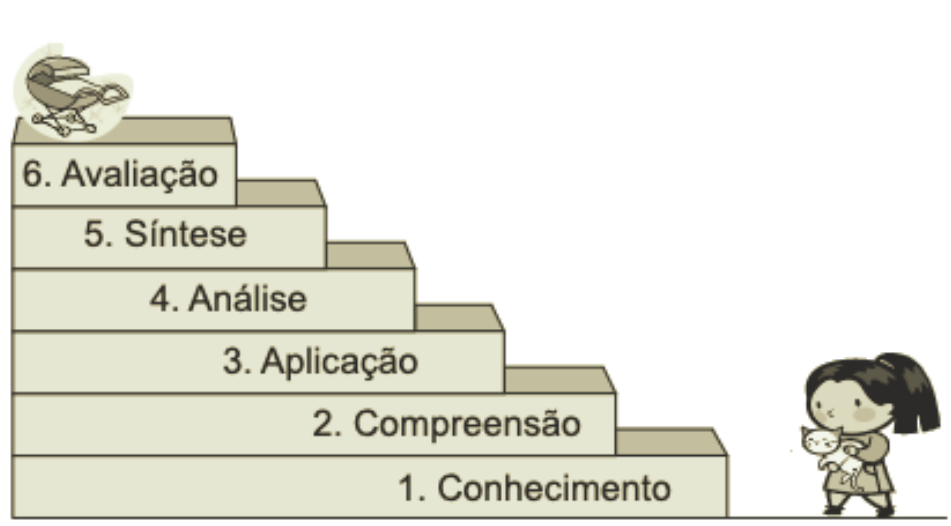

Figura 1. Categorias do domínio cognitivo proposto por Bloom, Englehart, Furst, Hill e Krathwolh, que ficou conhecido como Taxonomia de Bloom.

Figura 8 - Taxonomia de Bloom e legenda em artigo de Ferraz e Belhot (2010).

Há verbos utilizados nas descrições de objetivos de aprendizagem que se aplicam a cada um desses níveis, sendo "reconhecer", "conhecer" e "saber" localizados no nível 1, do conhecimento. Um exemplo de verbo para o nível imediatamente superior seria "ilustrar", "explicar", "classificar", donde se pode perceber a gradação crescente (FERRAZ; BELHOT, 2010). Não saberíamos dizer o quanto essa taxonomia é conhecida pelos professores brasileiros, no entanto, a clareza de sua proposta nos leva a trazê-la como importante

\footnotetext{
${ }^{27}$ Texto original: Knowledge "involves the recall of specifics and universals, the recall of methods and processes, or the recall of a pattern, structure, or setting."; Comprehension "refers to a type of understanding or apprehension such that the individual knows what is being communicated and can make use of the material or idea being communicated without necessarily relating it to other material or seeing its fullest implications."; Application refers to the "use of abstractions in particular and concrete situations."; Analysis represents the "breakdown of a communication into its constituent elements or parts such that the relative hierarchy of ideas is made clear and/or the relations between ideas expressed are made explicit."; Synthesis involves the "putting together of elements and parts so as to form a whole."; Evaluation engenders "judgments about the value of material and methods for given purposes."
} 
instrumento para auxílio no planejamento de aulas. Embora tenha havido uma atualização da Taxonomia de Bloom em 2001, sua versão original mostra-se suficiente para os objetivos deste trabalho.

O segundo procedimento de análise utilizado foi a observação das categorias discursivas de pessoa, espaço e tempo no enunciado. Conforme conceitos apresentados no capítulo 2 sobre enunciação, as análises aqui apresentadas se constroem sobre mecanismos de debreagem actorial e as relações que se estabelecem entre enunciador e enunciatário; debreagem e embreagem temporais e as particularidades que decorrem do uso do tempo no plano de aula online; e a debreagem espacial, com a observação do estabelecimento do espaço da aula, frequentemente semantizado nos planos. Em combinação com essas análises, busca-se observar o direcionamento de movimentação do discurso por meio da apreensão dos foremas que se podem depreender dos enunciados e a lógica que rege seu direcionamento, se implicativa ou concessiva (conforme explicitado no item 2.4).

Como modo de se apreender quais os valores que circulam nos planos de aula online, foi feita a análise dos percursos temáticos e figurativos presentes nos planos. Buscou-se também verificar se esses valores estavam explicitados nos PCN (item 1.3) e no tutorial de "Como criar uma aula" (item 1.4), de modo a ver o diálogo que se estabelecia entre eles e quais desses valores estavam respondendo à demanda pela construção do objeto valor "boa aula".

A partir das análises comparativas entre os planos de aula, foi possível estabelecer, da totalidade do corpus escolhido para análise, o ator da enunciação do plano de aula disponível online e também estabelecer quais os regimes de interação sobre os quais ele opera.

\subsection{Análise do plano de aula 01 - UCA - As potencialidades do conhecimento pela navegação na Internet: uma visita ao Museu da Língua Portuguesa}

Este primeiro plano de aula que trazemos para análise é chamado: UCA - As potencialidades do conhecimento pela navegação na Internet: uma visita ao Museu da Língua 
Portuguesa. Foi publicado em 05/09/2011 por Walleska Bernardino Silva, da Escola de Educação Básica de Uberlândia, MG, e possuía 3.498 acessos em março de 2018. Sua avaliação é de quatro estrelas, o que se considera bom. Sua inclusão neste corpus deve-se ao fato de ele estar bem avaliado e de sua temática cumprir bem o propósito do site, que demanda o uso da tecnologia em sala de aula.

Nesse plano de aula, propõe-se uma visita virtual ao Museu da Língua Portuguesa para aquisição de conhecimento sobre o museu e informação sobre ele, para discussão sobre sua importância e para disseminação do conhecimento sobre o museu para a comunidade escolar. São planejadas três aulas, duas no laboratório de informática e uma terceira, opcional, de visita presencial ao museu. O objetivo é visitar virtualmente o museu e discutir a importância do site do museu, mais do que a do museu em si. Valoriza-se, portanto, o papel da tecnologia na construção do conhecimento.

Na seção do plano de aula que trata dos objetivos (O que o aluno pode aprender com esta aula), os enunciados são feitos em debreagem enunciva temporal e actancial, produzindo o efeito de impessoalidade e objetividade. "Visitar e informar-se virtualmente sobre o Museu..."; "Discutir a importância de se ter um site sobre o museu..."; "Disseminar o conhecimento sobre o museu...". O destinatário desse discurso é o professor, colocado objetivamente pelos verbos no infinitivo. Em se tratando de um plano de aula, quando se diz "o que o aluno poderá aprender com essa aula", o que se lê deve ser "o que o professor irá fazer o aluno aprender com essa aula", pois o destinatário do plano online é o professor, e não o aluno. Os objetivos enunciam, portanto, o que o professor irá fazer o aluno fazer. Os verbos apresentam-se em aspecto durativo, infinito, subtraindo o aspecto terminativo, o que cria o efeito de um plano de aula que perdura, independente do tempo. São, assim, objetivos que permanecem, o que constitui um efeito que o enunciador busca produzir para o enunciatário, de um plano de aula cujos resultados serão contínuos, como se espera de um processo de educação. Percebe-se, também, que a descrição dos objetivos produz um movimento que vai do individual ao coletivo e que se caracteriza por ser de abertura. Primeiro se visita o museu virtualmente para, no site, obterem-se informações sobre o museu e seu funcionamento - atividade individual, ou em dupla, utilizando um computador, para ser feita pelos alunos sem a ajuda direta do professor. Em seguida, discute-se a importância de se ter 
um site sobre o museu - uma atividade em grupo, abrangendo vários sujeitos ou mesmo a sala toda juntamente com o professor. Por fim, o plano propõe a disseminação do conhecimento "na e para a comunidade", em um movimento de abertura para fora da sala de aula, fazendo com que o aluno, agora competencializado pelo saber, encaminhe-se na direção para fora da sala de aula.

Na seção "Conhecimentos prévios trabalhados pelo professor com o aluno", continuase a utilizar a debreagem actancial enunciva, tratando o professor em $3^{3}$ pessoa, obtendo-se o efeito de objetividade. Essa mesma estratégia discursiva prossegue ainda na seção seguinte, Estratégias e Recursos da Aula, na qual se descrevem as atividades. A descrição dessas aulas mostra-se bem marcada, em negrito, em uma linha "Aula 1" e, na linha de baixo, "Atividade", com numeração na aula 1, sem numeração nas outras. Esse modo de marcar a divisão das aulas e atividades no texto resulta em clareza na organização da aula, visual e enunciativamente, deixando marcado o percurso temático de organização.

Transcrevemos trecho inicial para que se possa observar o uso do tempo feito nessa seção:

\begin{abstract}
Atividade 1
A aula será desenvolvida a partir dos classmates dos alunos conectados à internet. O professor ao mesmo tempo estará acessando a web e sua navegação deverá ser exposta aos alunos por meio de um data show.

Os alunos receberão um tutorial e deverão em duplas seguir as orientações. As respostas aos tutoriais deverão ser digitadas no KWord e salvas.
\end{abstract}

TUTORIAL

[composto pela imagem da página inicial do site do museu e 11 perguntas direcionadas aos alunos - ver figura 9]

\title{
Atividade 2
}

Após resposta ao tutorial, os alunos enviarão os arquivos salvos aos colegas para que eles aprovem as respostas. Tendo, então, trocados os tutoriais, o professor abrirá uma roda de discussão para conversar com os alunos [...]. (negritos nossos)

Observa-se a utilização do futuro do presente para descrever o que será feito durante a aula: "será desenvolvida", "estará", "deverá ser", "receberão", "deverão". Observa-se também o uso de um advérbio de tempo "ao mesmo tempo", que indica a concomitância 
dessas atividades que acontecem nesse tempo futuro. A partir desse advérbio de tempo, pode-se afirmar que o agora do enunciador está instaurado em um momento nãoconcomitante ao momento presente da enunciação, um momento de referência futuro. Fiorin (2002: 142 e seguintes) nos explica que o discurso instaura-se em um agora do momento da enunciação, o que funda as oposições temporais da língua. Esse agora do enunciador passa a ser também o do enunciatário: é preciso que a temporalidade de um seja aceita pelo outro. No exemplo que temos neste plano, esse agora não se refere ao momento concomitante ao da enunciação, mas a um momento não-concomitante, posterior à enunciação, que passa a operar como o momento de referência desse plano de aula, construindo o que se denomina debreagem enunciva (referente ao enunciado, com a instauração de um sistema que gravita em torno de referentes ele, lá, então, por oposição à debreagem enunciativa, da enunciação, cujo sistema tem por referência eu, aqui, agora). 0 enunciador então projeta a aula, narrando-a. A projeção que cria o sistema enuncivo pode ser situada em um passado, anterior ao momento da enunciação, ou em um futuro, posterior. Neste plano de aula, e em outros, como veremos, o enunciador narra o que acontecerá no momento presente do futuro da enunciação (FIORIN, 2002: 160), no qual se desenvolverão as atividades, o que constitui um uso mais raro do sistema enuncivo.

Desse modo, cria-se, com essa debreagem enunciva, um efeito de predição, como se o enunciador construísse com o enunciatário a competência de se transportarem para um tempo futuro no qual a aula estaria realizada e fazendo produzir, por meio dessa estratégia discursiva, um simulacro da aula. Por definição, o uso do tempo futuro sempre carrega um traço de incerteza, de possibilidade. Essa estratégia, entretanto, pela criação do simulacro, faz enfraquecer esse traço, fortalecendo o traço de certeza. Enunciador e enunciatário posicionam-se nesse lugar de observar uma aula que se realizará porque está criada por esse enunciado situado nesse presente do futuro.

A partir disso, embora se utilize de uma estratégia discursiva enunciva, que tenderia a estabelecer certo distanciamento, decorrente da objetividade, entre enunciador e enunciatário, o uso da debreagem enunciva no futuro do presente, nesse ponto, mantém a objetividade, mas também produz uma cumplicidade como efeito da previsão, situando os dois juntos na aula que está sendo planejada. Coloca-se como hipótese que essa seja uma 
característica que torna o plano de aula online um objeto de valor desejável: ele torna possível a "realização imaginária" de uma aula antes de ela acontecer, o que produz um efeito que o enunciador deseja construir para o enunciatário, principalmente em se tratando de uma cultura como a nossa, que mostra dificuldades históricas com o planejamento ${ }^{28}$.

Este plano de aula mostra também momentos de alternância do uso da debreagem actancial enunciva para enunciativa. A partir do trecho reproduzido acima, podemos observar o uso da debreagem actancial enunciva: "A aula será desenvolvida...", "O professor ao mesmo tempo estará acessando a web...". Essa alternância acontece pela primeira vez logo no início da descrição da segunda atividade, ao falar do acervo do museu de língua portuguesa "a fim de disseminar o acervo que nos é tão caro: nossa língua." Ao utilizar a primeira pessoa do plural em vez da terceira, como vinha fazendo, o enunciador reforça o estabelecimento de um elemento comum entre ele e o enunciatário - a língua portuguesa - apelando à lembrança da identidade entre todos esses atores da enunciação e do enunciado. Em seguida, ao final da atividade 2 , aparece novamente uma debreagem enunciativa:

Atenção: professor, destaque com os alunos o ponto forte do Museu: a tecnologia aplicada ao espaço expositivo. Isso atrai e desperta a atenção dos visitantes. Conheça mais em:

[seguem-se três endereços web com links para acesso].

Esse enunciado dirige-se diretamente ao professor, em segunda pessoa, por meio de um vocativo que nomeia seu papel temático, reforçado no plano da expressão ao apresentarse em letras vermelhas e negrito e precedido de um "Atenção". O enunciado solicita (i) destaque para o fato de que o museu tem na tecnologia aplicada ao espaço expositivo seu ponto forte, justificando tratar-se de algo que é valorizado positivamente e que servirá de atrativo para os visitantes e (ii) fornecimento de locais onde serão encontradas informações adicionais sobre o tema. A utilização da debreagem enunciativa e seu efeito de subjetividade faz aproximar enunciador e enunciatário para que eles compartilhem informações de valor positivo e fortalece o contrato de fidúcia, segundo o qual o enunciatário crê que o enunciador possa construir nele a competência de "dar uma boa aula" porque, ao trazer fontes adicionais de informação sobre o tema da aula, traz para o destinatário mais do objeto que está em

\footnotetext{
${ }^{28}$ Ligamos a questão cultural da falta de planejamento à análise que fizemos da entrevista com Fusari, sobre a inevitabilidade do improviso na aula, no item 1.4.1 deste trabalho.
} 
construção, o saber fazer, para realizar a ação a que ele se propõe. O terceiro momento de alternância no uso da debreagem enunciva acontece na atividade 3, quando se diz "Aproveite, professor, a oportunidade para comparar o ganho de conhecimento virtual e presencial. Discuta os prós e contras." Assim como a anterior, essa utilização da debreagem enunciativa acontece no momento em que se fornecem informações adicionais, não essenciais à condução da aula, que trazem, no entanto, conteúdos importantes, que farão a diferença, seja para "atrair a atração dos visitantes", seja para "aproveitar a oportunidade para comparar o ganho". Ou seja, são utilizadas para contribuir positivamente para que aquela aula configurese como a "boa aula", objeto de valor eufórico buscado pelo professor no plano de aula online. Mostra-se, de modo claro, a alternância entre a construção de um momento de maior formalidade na relação entre enunciador e enunciatário, "essa é a aula que deve acontecer", e outro momento, de cumplicidade entre os atores da enunciação na construção dessa aula, algo como: "eis aqui o meu toque pessoal para que esta aula seja uma boa aula". Esses três momentos apontados de quebra no uso da debreagem enunciva pela enunciativa fortalecem a construção de uma identidade entre enunciador e enunciatário que tem por efeito reforçar o contrato fiduciário; nesse momento, a debreagem de tempo também é alterada para enunciativa, com o uso do presente simples.

Ainda se tratando da debreagem actancial, apontamos o uso da debreagem interna, ou debreagem em segundo grau, em momentos em que o enunciador constrói seu enunciado diretamente para o aluno. Trata-se de uma estratégia em que o enunciador, a partir de um actante do enunciado, debreia a ele a voz, instituindo-o como interlocutor, que se dirige a um interlocutário (GREIMAS e COURTES, s/d [1979]: 96). No plano de aula, essa debreagem de segundo grau faz com que o enunciador realize uma fusão com o enunciatário [do plano] e dirija-se diretamente ao aluno, papel temático do enunciatário da aula. A atividade 1 da aula 1 traz uma lista de perguntas que os alunos deverão responder enquanto visitam o site do museu, nessa parte que apontamos anteriormente e que é chamada no plano de aula de Tutorial, conforme se mostra na figura abaixo. 


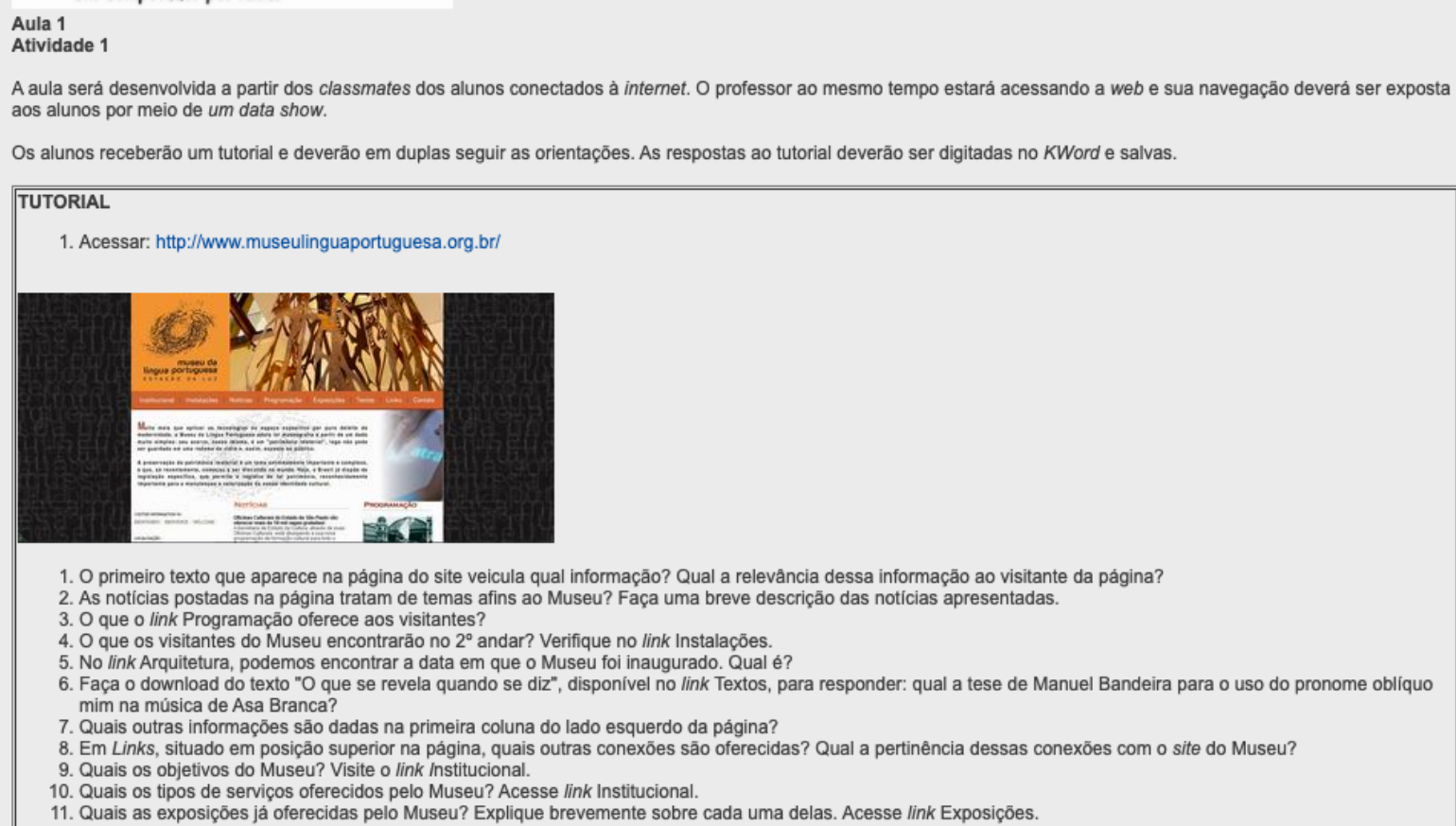

1. O primeiro texto que aparece na página do site veicula qual informaçâa? Qual a relevância dessa informaçăo ao visitante da página?

2. As noticias postadas na página tratam de temas afins ao Museu? Faça uma breve descrição das noticias apresentadas.

4. O que os visitantes do Museu encontrarão no $2^{\circ}$ andar? Verifique no link Instalaçōes.

6. Faça o download do texto "O que se revela quando se diz", disponivel no link Textos, para responder: qual a tese de Manuel Bandeira para o uso do pronome obliquo

6aça o download do texto "O ques

7. Quais outras informaçōes são dadas na primeira coluna do lado esquerdo da página?

7. Quais outras informaçōes são dadas na primeira coluna do lado esquerdo da página?

8. Qm Links, situado em posiçáa superior na página, quais do Museu? Visite o link Institucional.

10. Quais os tipos de serviços oferecidos pelo Museu? Acesse link Institucional.

11. Quais as exposiçōes ją oferecidas pelo Museu? Explique brevemente sobre cada uma delas. Acesse link Exposiçōes.

Figura 9 - Tutorial da aula 1, plano de aula 01.

TUTORIAL

1. Acessar: http://museulinguaportuguesa.org.br

[imagem que reproduz a tela inicial do site do museu]

1. O primeiro texto que aparece na página do site veicula qual informação? Qual a relevância dessa informação ao visitante da página?

2. As notícias postadas na página tratam de temas afins ao Museu? Faça uma breve descrição das notícias apresentadas.

3. O que o link Programação oferece aos visitantes?

4. O que os visitantes do Museu encontrarão no $2^{\circ}$ andar? Verifique no link Instalações.

5. No link Arquitetura, podemos encontrar a data em que o Museu foi inaugurado. Qual é?

6. Faça o download do texto "O que se revela quando se diz", disponível no link Textos, para responder: qual a tese de Manuel Bandeira para o uso do pronome oblíquo mim na música de Asa Branca?

7. Quais outras informações são dadas na primeira coluna do lado esquerdo da página?

8. Em Links, situado em posição superior na página, quais outras conexões são oferecidas? Qual a pertinência dessas conexões com o site do Museu?

9. Quais os objetivos do Museu? Visite o link Institucional.

10. Quais os tipos de serviços oferecidos pelo Museu? Acesse link Institucional. 
11. Quais as exposições já oferecidas pelo Museu? Explique brevemente sobre cada uma delas. Acesse link Exposições.

Os verbos estão enunciados no presente do indicativo: "aparece", "tratam", "oferece"; e no imperativo "faça", "acesse", "explique". Fiorin (2002: 46) nos traz que a debreagem interna cria o efeito de sentido de realidade, pois parece que o próprio personagem toma a palavra. No caso do plano de aula, esse efeito de sentido de realidade reforça o efeito de simulacro da aula realizada. Para Greimas e Courtés (s/d [1979]: 96), esse efeito é chamado de referencialização, ou seja, resulta de uma ancoragem do discurso a uma grandeza não semiótica, "do mundo". Reforça-se assim o efeito de predição de construção do momento da aula, fazendo do plano seu simulacro e trazendo o aluno, destinatário da aula, para dentro do plano.

Quanto ao espaço, voltemos ao enunciado que marca o início da descrição das atividades (aula 1, atividade 1, reproduzida acima e na figura 9). Note-se que, do mesmo modo que a debreagem de tempo produzida é enunciva, a de lugar também o é, com a instauração de um "não-aqui" no enunciado: lá é onde acontecerá a narrativa prevista para esse momento futuro.

O modo como o espaço discursivo deste plano de aula se figurativiza nos permite agregar à análise discursiva também uma análise do espaço tensivo. Observa-se nele um movimento do fechamento à abertura. No início da atividade 2, enuncia-se "Tendo, então, trocados os tutoriais, o professor abrirá uma roda de discussão para conversar com os alunos...". Passa-se do fechamento da atividade em duplas, em frente ao computador, à abertura da roda de discussão, na qual todos participam. Essa abertura insere esse plano em uma direção extensa, tendendo à universalidade. Pode-se também notar o movimento contido na proposta existente no título da aula, "as potencialidades do conhecimento pela navegação na Internet", mostrando que o conhecimento se desloca entre o mundo virtual e o mundo físico, escolar, e entre o questionário em duplas, mais fechado, e a discussão em roda, mais aberta. Há uma fluidez na informação que navega entre os espaços figurativizados como sala de aula, colocado como uma posição de interioridade, e como o espaço virtual do museu, da exterioridade, o que amplia o espaço da aula e faz parecer que ela acontece em 
mais de um lugar ao mesmo tempo. O elã do deslocamento desse espaço visa a criar um efeito de intensificação da presença realizada da aula, de sua construção como uma predição.

Na proposta da segunda aula desse plano, pede-se que os alunos divulguem na comunidade o conhecimento adquirido na página do museu, por meio da produção de gêneros diversos que "disseminem as informações". Tem-se na figurativização desses dois lugares, a comunidade e o site do museu, a expansão do espaço do sujeito da enunciação para além do da sala de aula, para a comunidade escolar onde "todos esses gêneros [de texto] deverão circular". A menção à circulação dos textos produzidos intensifica não apenas o efeito do movimento modulatório do plano de aula sobre o eixo da extensão, mas também o fazer do destinador que visa a sustentar a continuação da aula e a fazer perdurar seus efeitos, criando esse efeito de progresso narrativo.

Outro momento em que se colocam oposições semânticas de espaço nesse plano de aula é na atividade da aula 3, que propõe a visita presencial ao museu. Diz o plano:

O professor poderá organizar com os alunos uma visita ao Museu da Língua Portuguesa para apreciarem de perto o que viram e desfrutaram via internet. Aproveite, professor, a oportunidade para comparar o ganho de conhecimento virtual e presencial. Discuta os prós e contras. Para aproximar família e escola, o passeio poderá contar com a presença dos pais. (grifos nossos)

Opõe-se aqui a visita virtual, de longe, à visita presencial, "de perto", e propõe-se que se discuta e se compare a diferença entre elas. Também é proposto que a família e a escola "se aproximem". Esse movimento entre próximo e distante também acentua a proposta da aula de apreensão de conhecimento pelo deslocamento do sujeito entre o meio virtual e o meio físico, de modo complexo, de um e outro modo.

Em relação à semântica discursiva, voltando às Estratégias e Recursos da aula, parte do plano de aula que descreve como devem ser as aulas, examinemos a primeira instrução da aula 1, atividade 1, já reproduzida acima. A presença de palavras em inglês que fazem referência a elementos da computação compõe um percurso temático de contemporaneidade, de conexão ao mundo virtual, constituído majoritariamente por termos em inglês ou derivados dele. Temos, assim: "Classmates", "internet", "web", "data show", "Kword". Ao iniciar a aula desse modo, instauram-se essas marcas que condizem com o 
percurso temático proposto pelo título e pela proposta da aula, de visita virtual a um museu cujo acervo é composto por tecnologia também. Coloca-se aqui um percurso temático da tecnologia como meio contemporâneo de aquisição de conhecimento, cujo valor é eufórico, o que pode ser ainda confirmado ao se observar a figura que acompanha essa primeira atividade: um desenho de quatro alunos sorridentes carregando, cada um, um instrumento de aula ou de tecnologia (um lápis, um computador portátil, uma câmera de vídeo e uma lupa), embaixo da qual se lê "UCA um computador por aluno". Ao que tudo indica, esses são os "classmates conectados à internet".

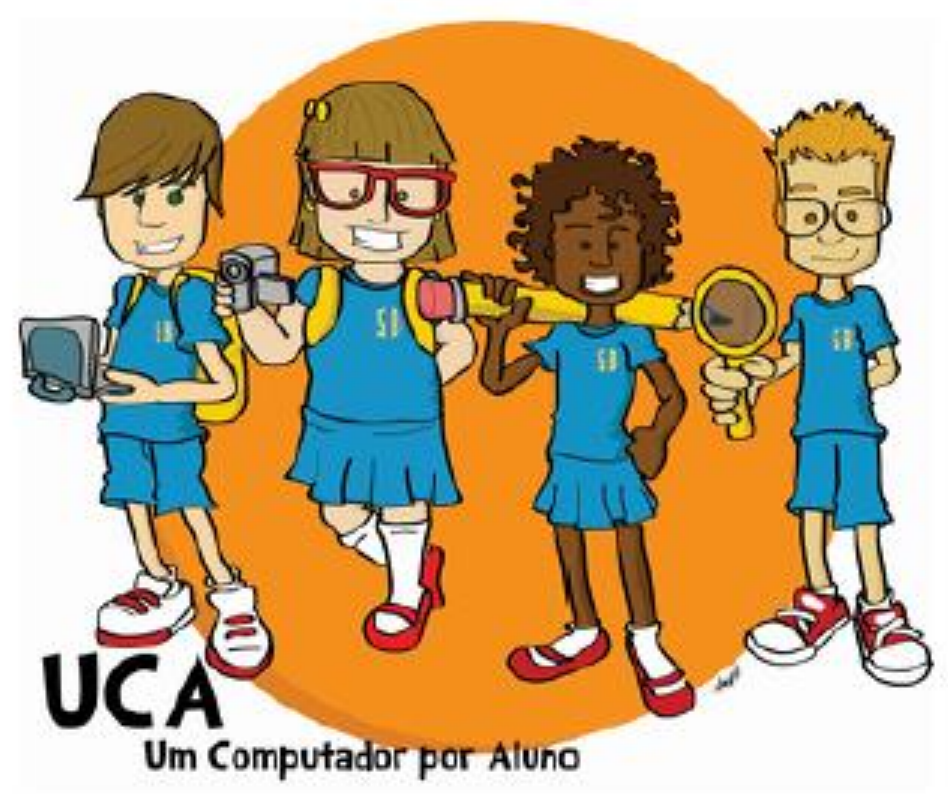

Figura 10 - retirada do plano de aula 01 mostrando os classmates.

Note-se que as atividades são apresentadas de forma sequenciada: 1. acessar o site; 2. responder à pergunta $x$ referente ao primeiro texto; 3 . responder pergunta; e assim por diante. São claras as instruções de sequência mesmo quando não numeradas: "após resposta ao tutorial...", "Tendo, então, trocados os tutoriais, o professor abrirá...". Essa sequenciação explícita guia o professor enquanto ele estiver realizando sua performance de dar a aula. Instaura-se, assim, um percurso temático da prescrição, da execução organizada da ação, 
eufórico por estar dentro da programação, regime de interação que se apresenta de modo acentuado nesse trecho do plano de aula.

As perguntas propostas pela atividade servem de guia para a exploração da página inicial do site do museu. Elas posicionam o leitor espacialmente: "coluna do lado esquerdo", "posição superior da página". Elas fazem com que se percorra cada um dos links disponíveis "acesse o link", "visite o link", "verifique o link". Ainda que apresente várias questões (onze, ao todo), há, incluída na solicitação, a brevidade da resposta: "faça uma breve descrição", "podemos encontrar uma data - qual é?", "explique brevemente". Coloca-se aqui um percurso temático da exploração guiada para informação, porém uma exploração que não se demora, que se apresenta mais acelerada e que corrobora o tema do uso da tecnologia.

Perpassando todas as questões, apresenta-se o tema de informação "texto", "informação", "notícia postada", "notícia apresentada", "data", "outras informações", proposto explicitamente nos objetivos da aula. Estão, portanto, construídos na aula 1 os temas da tecnologia como ferramenta de construção de conhecimento, da organização e da exploração de informações, eufóricos, desejáveis. A aula proposta para ser o objeto valor "boa aula" com a qual o professor busca entrar em conjunção é uma aula que irá guiá-lo na aquisição e transmissão de um conhecimento com seus alunos de modo sequenciado, organizado, com o uso da tecnologia.

Em síntese, tem-se, no plano de aula 01, uma alternância de uso de debreagem actorial enunciva e enunciativa, com predominância da primeira, e uso de debreagem temporal predominantemente enunciva, com o uso do futuro como momento de referência nãoconcomitante ao momento da enunciação; idem para o espaço discursivo. Há um movimento do saber no espaço tensivo desse plano de aula que se expande em abertura, deslocando-se da interioridade para a exterioridade. Os objetivos são enunciados como durativos. Como percursos temáticos, mostrando o revestimento semântico dos temas que permeiam de modo eufórico o plano, apresentam-se o uso da língua inglesa e de termos da tecnologia, a sequenciação que organiza a aula e o tema da informação. 


\subsection{Análise do plano de aula 02 - Entendendo as funções da linguagem.}

Este plano de aula intitula-se Entendendo as Funções da Linguagem e é de autoria de Júlia Maria Cerqueira, da Universidade Federal de Juiz de Fora. Foi publicado em 20/12/2009. Possuía 68.562 acessos em março de 2018 e foi avaliado como 4 estrelas. Recebeu 76 comentários e constou entre os dez primeiros na lista dos planos de aula mais relevantes, quando utilizado esse filtro no site Portal do Professor para plano de Língua Portuguesa na primeira coleta do corpus, em 2015-2016. Ele continuou aparecendo em primeiro lutar entre os dez planos de aula mais comentados em janeiro de 2020.

Propõe que se trabalhem as funções da linguagem por meio de textos diversos que serão apresentados aos alunos e faz perguntas que direcionam o trabalho do professor para cumprir a tarefa de levar os alunos a conhecerem as funções de linguagem presentes ou predominantes nos textos. Como objetivo, na seção "O que o aluno poderá aprender com esta aula", o plano de aula coloca: "Compreender as funções da linguagem: referencial (ou denotativa), conativa (ou apelativa), fática, emotiva (ou expressiva), poética e metalinguística." Assim como feito no plano 01, os objetivos são enunciados utilizando-se o verbo na forma infinitiva, trazendo o efeito de plano que perdura. Na seção seguinte, chamada "Conhecimentos prévios trabalhados pelo professor com os alunos", pede-se, de modo sucinto, apenas "Habilidades básicas de leitura". Em ambos, temos um enunciador produtor de enunciados curtos e objetivos, que se utiliza de debreagem enunciva, na primeira seção utilizando o verbo no infinitivo e, na segunda, sem utilizar verbo, apenas nomeando a habilidade necessária para aquela aula, produzindo, assim, o efeito de impessoalidade, reforçada pela brevidade dos enunciados que contêm apenas o essencial em termos de informação.

A seção "Estratégias e Recursos da aula", que é a parte mais longa do plano e na qual são descritas as atividades propostas, subdivide-se em cinco etapas ${ }^{29}$ : a primeira trata de duas funções da linguagem e as compara, as seguintes contêm apenas uma função da linguagem cada.

${ }^{29}$ O plano numera, equivocadamente, as duas últimas etapas com o número quatro. 
ETAPA 1: CONHECENDO A FUNÇÃO REFERENCIAL OU DENOTATIVA E A FUNÇÃO CONATIVA OU APELATIVA

Peça aos alunos que leiam os dois textos que se seguem. O primeiro, da jornalista Poliani Castelo Branco, refere-se ao início da História do voto em nossa pátria, quando ela ainda nem se chamava Brasil. O segundo diz respeito à importância do voto, trata-se de uma campanha organizada pelo Tribunal Superior Eleitoral (TSE), ${ }^{30}$ (negritos nossos)

O uso de verbos no presente simples do modo imperativo indica que a estratégia discursiva utilizada é a debreagem enunciativa, colocada de modo como mais comumente se vê em textos do tipo manuais de instrução. Todas as etapas iniciam-se com "Peça aos alunos que..." e uma delas, a segunda, coloca um vocativo antes da instrução: "Professor: peça aos alunos que...", tematizando o enunciatário. Não há nesse plano o uso do tempo futuro, como visto no plano 01. Com o uso da debreagem enunciativa e do tempo presente, institui-se o tempo da aula como um agora compartilhado entre enunciador e enunciatário.

Em três momentos, nessa seção que explica as atividades, o enunciador interpela o professor por meio de um vocativo, "PROFESSOR: ....", no início de uma nova linha de instruções. Parece uma redundância, já que o verbo está se dirigindo ao enunciatário por apresentar-se no imperativo. No entanto, obtém-se um efeito de ênfase e de força enunciativa, reforçando o papel temático do enunciatário. Também é recorrente nesse plano o imperativo utilizado para solicitar que o professor peça aos alunos ou conduza os alunos. Na etapa 1: "Peça aos alunos...", "Em seguida, leve os alunos a...", "Coloque esta questão para seus alunos.", "Leve-os a perceber que...". Na etapa 2: "PROFESSOR: Peça aos alunos...", "Em seguida, pergunte a eles:", "Pergunte a ele ...", “Explique a eles...". Na etapa 3: "Peça aos alunos...", "Pergunte aos alunos...". Na etapa 4, com "Peça aos alunos...", "Pergunte aos alunos", "Chame-os a atenção [sic] para ...", "Leve-os a perceber..." Na etapa 5 (segunda enumeração da etapa 4): "Peça que os alunos leiam...", "Explique a seus alunos que...". A recorrência de "Peça aos alunos" e de "Pergunte aos alunos" explicita um enunciador que faz o enunciatário fazer o aluno fazer e também evidencia um acento mais deôntico para esse plano de aula.

\footnotetext{
${ }^{30}$ Esse parágrafo termina com uma vírgula.
} 
O enunciador também propõe perguntas que devem ser dirigidas diretamente aos alunos e fornece suas respostas ao professor.

Como ele o faz? Coloque esta questão para seus alunos. Leve-os a perceber que o primeiro avisa sobre uma possível sanção, caso não se vote nos "melhores candidatos a prefeito e a vereador".

Que sanção seria esta? A resposta é que a cidade perderia quatro anos [...].

Trata-se de uma debreagem interna, em que o enunciador se funde ao enunciatário do plano e se dirige diretamente ao enunciatário da aula, o aluno. Essa debreagem interna, ou de segundo grau, apaga a diferença entre enunciador e enunciatário do plano de aula e reforça a construção do simulacro da aula. Ela é construída de modo bem mais breve do que no plano 01, que propunha um tutorial com toda uma série de perguntas dirigidas diretamente ao aluno.

Para apresentar cada uma das funções da linguagem, o plano de aula traz um texto de exemplo, verbal ou sincrético (verbal e imagético) e propõe as perguntas e respostas para o professor levar o aluno a conhecer a função da linguagem predominante naquele texto. Há referências constantes e explícitas de sequenciação, tanto entre as etapas em que a aula deve se desenvolver, que aparecem numeradas, quanto para as atividades. Para os textos trazidos são fornecidas informações como: "O primeiro, da jornalista Poliane Castelo Branco, referese ao início da história do voto em nossa pátria..."; "O segundo diz respeito à importância do voto, trata-se de uma campanha organizada pelo Tribunal Superior Eleitoral (TSE)." Essas informações complementares situam o texto em relação a outros textos, explicitando o dialogismo existente entre eles e, com isso, ao fazer essa referenciação da aula, ajudam a construir o contrato fiduciário entre os sujeitos. O uso frequente de palavras e locuções adverbiais que indicam temporalidade, evidenciando qual a sequência do desenvolvimento das atividades, mostra a organização, a sequência das falas e exercícios, o que constitui o percurso temático de sequenciação, como visto também no plano 01.

Os temas abordados nos textos trazidos como exemplos para as duas primeiras funções da linguagem, "eleições", "a importância do voto", "a vida depende do voto", "escolher os melhores candidatos", "nas eleições, você é o patrão", constroem um percurso temático da cidadania, em resposta ao que se solicita nos PCN como primeiro objetivo para o 
Ensino Fundamental, "compreender a cidadania como participação social e política, assim como exercício de direitos e deveres políticos, civis e sociais" ${ }^{31}$. Para essas duas funções da linguagem, falando de eleições, os quatro textos (três em forma de cartaz e um apenas texto) trazem: (i) “A história do voto no Brasil começou 32 anos após Cabral ter desembarcado no país", trata-se de um texto verbal; (ii) "se, nas próximas eleições, você não escolher os melhores candidatos a prefeito e vereador, sua cidade vai perder 4 anos. E 4 anos é muito tempo.", trata-se de um cartaz de fundo preto com letras coloridas em tons de verde, amarelo e laranja; (iii) "A vida depende do seu voto. Escolha candidatos que são contra o aborto." (figura 11, abaixo, cartaz 3), texto sincrético composto por esse enunciado em um fundo amarelo, ao centro se encontra a imagem de uma urna de votação eletrônica e, no visor da urna, a foto de um bebê branco e sorridente em que está escrito ‘Deixe-me nascer!'; (iv) “Nas eleições, você é o patrão. Escolha bem seus funcionários." (figura 12, abaixo, cartaz 4), texto sincrético que traz, no topo, a foto de um homem negro vestindo uma camisa azul marinho, com tapa ouvidos pousados ao redor do pescoço, luvas e capacete pousados sobre a mesa, que constroem o papel temático de um operário; esse homem está sentado atrás de uma escrivaninha de madeira, em uma cadeira de encosto alto estofado, com um painel de madeira atrás, o que constrói um cenário de um escritório de luxo; o contraste entre o lugar e a vestimenta do homem figurativiza os papéis temáticos 'patrão' e 'funcionário', do enunciado verbal. O tema da cidadania, portanto, distribui-se e associa-se (i) ao tema histórico, (ii) ao tema da importância da escolha do melhor candidato, (iii) à oposição vida e morte, com o voto simbolizando a vida e, em (iv), ao tema da inversão de papéis, colocando o operário como patrão, significando que o operário é quem elege e quem tem o poder de "contratar", por meio de seu voto, os funcionários públicos.

\footnotetext{
31 Brasil. Secretaria de Educação Fundamental. 1998, página 7.
} 


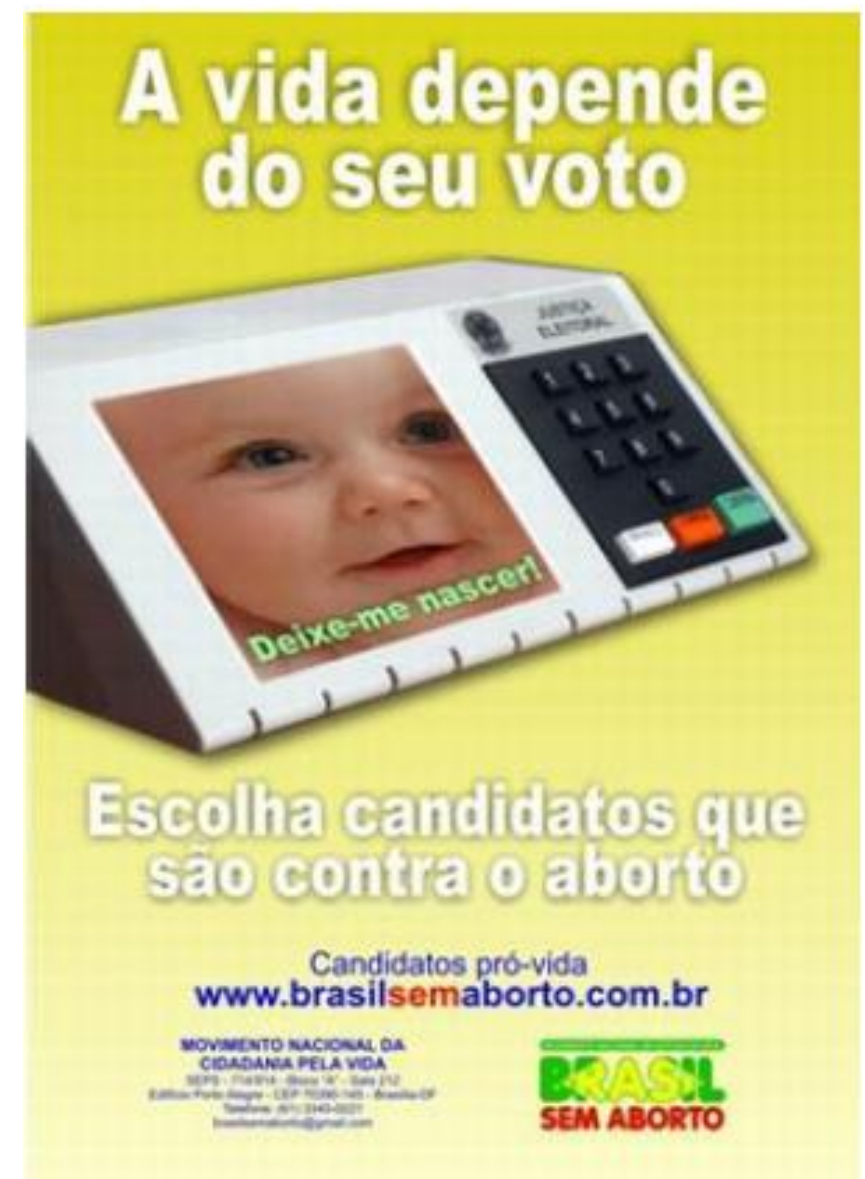

Figura 11 - Cartaz 3 do plano de aula 02

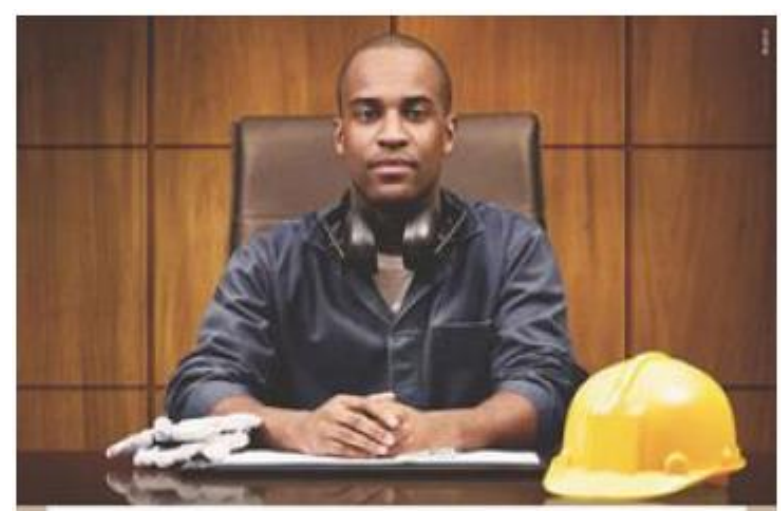

NAS ELEIÇ̃̃ES, VOCÊ É O PATRÃO. ESCOLHA BEM SEUS FUNCIONÁRIOS.

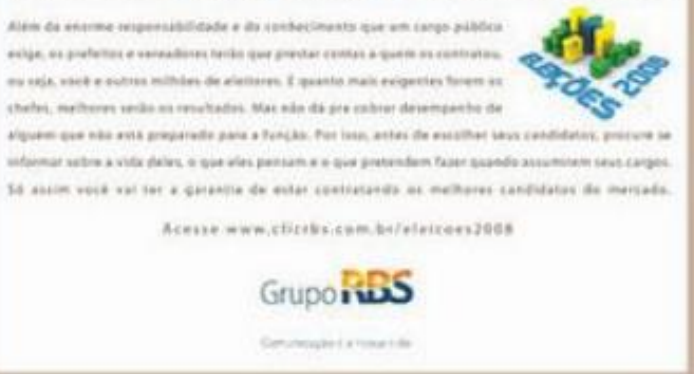


Figura 12 - Cartaz 4, do plano de aula 02

Os cartazes 1 e 2 são apresentados no plano de aula para serem utilizados como exemplo das funções de linguagem referencial e conativa, juntamente com a apresentação de questões dirigidas ao aluno para levá-lo à conclusão de qual função de linguagem é predominante neles. Diz-se do cartaz 1 que ele "é objetivo e informa sem julgamentos" e do cartaz 2 que "procura influenciar o leitor" por meio de uma possível sanção, que seria a perda de quatro anos para a cidade. Os cartazes 3 e 4 são introduzidos pela frase: "Abaixo, seguem outros exemplos de propaganda eleitoral, como opção ou complemento do assunto:", e não faz nenhum comentário sobre eles. Curiosamente, são os dois textos em que o enunciador mostra mais claramente um posicionamento político, contra o aborto e pela atribuição de poder à classe operária. Ao colocá-los no plano de aula como "opção ou complemento", ou seja, facultativos de serem utilizados, e sem comentá-los ou problematizá-los, o enunciador mostra seu posicionamento de modo claro, porém tácito. Tem-se um enunciador conservador em uma questão e progressista em outra, numa contradição aparente que se resolve pela observação de que esse conservadorismo se acentua na estratégia de apresentação escolhida: propõe-se uma questão, mas não se a comenta, optando pelo silenciamento e pela omissão em relação ao tema; ele faz parecer que as questões de posicionamento político não estão ali.

Para explicar a terceira função da linguagem, fática, há dois textos: uma imagem com um gancho de telefone, o fio do telefone e um balão que diz "Alô? Alô?", e uma tirinha de Mafalda na qual há um diálogo entre ela e o personagem Miguelito.

No primeiro quadrinho, Miguelito está sentado em frente à TV e Mafalda chega:

- Oi, Miguelito! Coisa boa na TV?

- Acabei de ligar.

No segundo quadrinho, Miguelito responde, de frente para Mafalda (só aparecem os rostos dos personagens):

- Mas parece que se você passa desodorante, depois come salsichas e aí compra uma máquina de lavar roupas, só não é feliz se for muito idiota.

As instruções que seguem pedem para perguntar aos alunos: "Por que temos o hábito de atender ao telefone dizendo 'alô'?" E, depois “Observando novamente a segunda figura, pergunte a eles por que Mafalda (a personagem feminina) diz 'Oi, Miguelito!' antes de Ihe 
fazer a pergunta?" Desta vez não há debreagens internas, mas um enunciador que pede ao enunciatário que se dirija aos alunos.

Também não se explora a crítica às propagandas mostradas na televisão que incentivam o consumo como produtor de felicidade contida na tirinha de Mafalda, mencionando-se apenas a função da linguagem presente na saudação da personagem. Comparamos esse mostrar de modo átono (o conteúdo está lá, mas não se chama atenção para ele) à característica apontada no exemplo da função da linguagem anterior, de colocar o posicionamento político no exemplo "opcional". Ambos estão na ordem do "dizer sem ser dito". Pode-se concluir que este plano de aula não aproveita a oportunidade para trabalhar temas transversais que construiriam criticidade nos alunos, mas, ao mesmo tempo, deixa esses temas no plano, caso o professor decida utilizá-los em sua aula. Ou, também, podemos entender que esse enunciador quer minimizar os riscos de que seu plano de aula não seja aceito por conta de posicionamentos políticos, como apresentar uma campanha contra o aborto ou uma tirinha em que se critica o consumismo. Também podemos dizer que se trata de uma estratégia de manipulação que permite ao enunciatário aderir ao plano de aula mesmo que não concorde com algum de seus posicionamentos. Ao não problematizar, o enunciador opera de modo mais distenso, tendendo ao não-polêmico.

Chama a atenção o fato de que este plano de aula não propõe exercícios de fixação nem endereços de sites que tratem do assunto, nem bibliografia complementar. Isso é encontrado nos outros planos de aula online analisados, o que faz com que espelhem a extensidade da internet, apontando para a profusão de fontes de informação que ela contém, e funciona como uma abertura para o mundo. Por isso, dizemos que se trata de um plano de aula mais fechado. Também não há nenhuma menção ao espaço, donde se pode inferir que se trata de um espaço enunciativo, dada que as debreagens temporal e actorial o são. Podemos afirmá-lo com base em Fiorin (2002: 262) que diz que o espaço, o hic, se organiza a partir do ego, ou seja, é o enunciador quem estabelece o espaço da enunciação a partir do ponto de referência em que se coloca.

Em relação à duração das atividades, divididas em cinco etapas, o plano de aula também não explica suficientemente como proceder com elas. De nossa experiência, acreditamos que, caso queira dedicar quatro aulas a esse assunto (como estabelecido no início 
do plano), o professor, destinatário do plano, precisará acrescentar às atividades propostas outras de sua autoria, pois elas não são suficientes para preencher o tempo proposto. De todo modo, preenchendo-se o tempo com mais atividades ou diminuindo o tempo total do plano de aula para utilizar apenas as atividades propostas, o professor precisará utilizar de sua competência existente para que seu fazer seja bem sucedido. Outros planos de aula, como o plano 01, fazem essa distribuição de atividades pelo tempo da aula de modo que demande menos planejamento do professor destinatário.

Sobre a organização sequencial deste plano, das seis funções da linguagem que constituem o conteúdo da aula, há duas explicadas na etapa 1 , uma na etapa 2 , uma na etapa 3 e a etapa 4 aparece duas vezes, uma com a função poética e outra para a metalinguística. Trata-se de uma organização não linear, quer dizer, nem se trata de uma etapa para cada aula, nem de uma etapa para cada função. Além disso, há a repetição de numeração da etapa 4, o que atrapalha a apreensão da organização do plano que, encontrando-se na ordem da programação, careceria de elementos mais cuidadosamente ordenados.

Tem-se, em resumo, para o plano 02, a utilização de debreagem actorial, temporal e espacial enunciativas, sem alternância com o uso de debreagem enunciva que ocorre em outros planos e com o uso do vocativo "professor" em alguns momentos. Constroem-se os percursos de sequenciação e da cidadania, mas não há abertura deste plano para o mundo digital, como solicitado pelo site nas instruções para a construção de um bom plano de aula. Trata-se de um plano que traz questões de posicionamento político e crítico como conteúdo, mas não os desenvolve, optando pela segurança de minimização do risco de interação e apostando em um consequente aumento de suas chances de aceitação (não apenas de publicação, mas também de utilização).

\subsection{Análise do plano de aula 03 - Coesão textual: o pronome na construção do texto.}


Este plano de aula chama-se Coesão Textual: o pronome na construção do texto. Sua autora é Lazuita Goretti de Oliveira, da Escola de Educação Básica de Uberlândia, MG, e ele foi publicado em 18/12/2009. Ele aparece entre os dez primeiros na lista das aulas "mais relevantes" de Língua Portuguesa para o Ensino Fundamental 2, e tinha quase 180 mil acessos no início de 2018 (em janeiro de 2020, 219 mil acessos). Também aparece na lista de planos mais comentados em janeiro de 2020, com 35 comentários. Trata-se de um plano de aula que propõe trabalhar o uso dos pronomes em sala de aula a partir de (i) uma pesquisa na internet a respeito do tema; (ii) exercícios com tirinhas e (iii) exercícios com um conto. Propõe-se que o trabalho dure 4 aulas de 50 minutos e seja parcialmente feito no laboratório de informática.

Como objetivos da aula, esse plano faz uma proposta mais detalhada do que os anteriores. Reproduzimo-la a seguir:

O que o aluno poderá aprender com esta aula:

- reconhecer e empregar pronomes como elementos coesivos responsáveis pela reativação do referente em um texto;

- conhecer as diversas formas de referência pronominal associadas às diferentes possibilidades de se dirigir a interlocutores em diferentes contextos de comunicação;

- reconhecer diferenças entre a norma padrão e o uso não padrão de pronomes em textos diversos;

- saber que a escolha pronominal está condicionada a fatores, tais como: a natureza do texto, o grau de formalidade ou informalidade, os objetivos da interação, a natureza da modalidade, se oral ou escrita.

Trata-se de uma descrição de objetivos mais extensa do que as outras que observamos nos planos de aula 01 e 02, mais detalhada e que se mostra preocupada com a relação dos pronomes com suas condições de uso, em vez de apenas preocupar-se com seu reconhecimento. No entanto, cabe ressaltar que os verbos empregados nos objetivos, "reconhecer", "conhecer" e "saber", são, de acordo com a Taxonomia de Bloom, bastante fracos como objetivo de aprendizagem da aula, e o único verbo que se apresenta mais tônico é "empregar"32, indicando que se visa ao uso dos pronomes pelos alunos ${ }^{33}$. Os PCN de Língua Portuguesa valorizam positivamente a tonicidade nos objetivos, que nesse plano apresenta-

\footnotetext{
32 De acordo com Ferraz e Belhot (2010), "empregar" encontra-se no nível (3) da taxonomia, o da aplicação.

${ }^{33}$ Ao final deste capítulo, na comparação entre os planos, nos deteremos mais sobre a relação entre os objetivos dos planos e a Taxonomia de Bloom.
} 
se de modo parcial. A utilização da debreagem enunciva traz, por sua vez, efeito de objetividade, reforçada pela apresentação dos objetivos em formato de lista de itens. O uso de verbos no infinitivo, como já observado nos planos 01 e 02 , cria o efeito não apenas de objetividade, mas também de duratividade do plano no eixo temporal, com objetivos de aprendizagem cujos efeitos perduram.

Como conhecimentos prévios trabalhados pelo professor com os alunos, o plano pede que eles conheçam os pronomes, identificando-os como pessoais, possessivos, demonstrativos, indefinidos e interrogativos, e pede que ele conheça os termos essenciais da oração (sujeito e predicado). Do mesmo modo que para os objetivos, essas exigências são colocadas em itens e enunciadas usando verbos no infinitivo, "conhecer". A solicitação apresenta-se coerente com o objetivo e o conteúdo da aula.

Na seção "Estratégias e Recursos da aula", antes de iniciar a descrição das atividades, o plano coloca, em formato de lista de itens, "reprodução de tirinhas veiculadas na internet" e "utilização do laboratório de informática". Põe, assim, em destaque, o uso da internet e o uso da tecnologia como itens da aula, em consonância com o que é solicitado pelo Portal do Professor de que a tecnologia a serviço da transmissão e construção de conhecimento seja um objeto de valor eufórico nos planos de aula online.

A descrição da aula está dividida em quatro partes. Essa divisão é bem marcada, em negrito, sozinha em uma linha "Aula 1" e, na linha de baixo, "Atividade". Para as outras aulas, a estratégia se repete, o que resulta em clareza na organização da aula, visual e enunciativamente, marcando bem o percurso temático de organização.

A aula 1 inicia-se com um aviso, "Importante", seguido do uso de um vocativo: "professor", nomeando o papel temático do enunciatário. No entanto, não há uso de formas verbais que demonstrem que o enunciador se dirige ao enunciatário como um "tu": os verbos aparecem todos em terceira pessoa. Tem-se, assim, uma debreagem enunciativa, marcada pelo vocativo, mas construída de forma mais objetiva por efeito do uso dos verbos em terceira pessoa (a não-pessoa). Nesse primeiro "aviso de importância", o enunciador se dirige ao enunciatário, interpelando-o, explica brevemente o que é coesão e qual a importância dos pronomes para tratar dela. 
Importante: Professor, Coesão textual trata-se [sic] da ligação, da conexão entre as palavras de um texto, por meio de elementos formais, que assinalam o vínculo entre os seus componentes. A coesão textual pode se estabelecer por meio de diversos elementos linguísticos. Dentre esses elementos, os pronomes assumem grande relevância, principalmente, pelo fato de ser por meio deles que se faz a retomada do referente, isto é, aquilo a que o texto se refere. Todos os tipos de pronomes podem funcionar como recurso de referência a termos ou expressões anteriormente empregados. (negrito no original)

A estratégia discursiva que acontece nesse trecho inicial se repete no último item do plano, o da avaliação, que veremos a seguir, em que o enunciador também se dirige ao professor como enunciatário por meio de vocativo, mas continua com a construção de enunciados que não marcam o direcionamento a um "tu". Essas duas ocorrências contrastam com o restante da descrição das aulas, nas quais se faz uso da debreagem enunciva e que, em grande parte, usam "professor" ou "aluno" como sujeito da oração.

No item “Avaliação" tem-se:

Professor, para avaliação de um tópico tão complexo como o emprego dos pronomes na construção do texto, não se deve levar em conta somente as regras prescritas pela norma padrão. Faz-se necessário apresentar aos alunos diversas situações de uso que vão determinar critérios de correção que se relacionam com a adequação de uma forma a uma dada situação. Certamente, o mais importante é a ampliação do repertório linguístico do aluno, apresentando-lhe outros usos que fogem do seu universo comunicativo, mas que estão presentes em alguns discursos. (negrito no original)

Ambos os usos do vocativo introduzem momentos em que o enunciador se põe a explicar ao enunciatário sobre a importância do tema ou a de se tratar o tema a partir de determinado ponto de vista, trazendo a ele a ampliação de seu universo linguístico ao apontar os contrastes entre norma culta e usos que estejam situados em universos outros. Trata-se de uma estratégia para criar o efeito de sentido de aproximação entre enunciador e enunciatário.

Ressalte-se também, em negrito, nesse segundo trecho, a recorrência de um traço de abertura, verificado em "ampliação", "outros usos", "que fogem do seu universo comunicativo", o que indica pontos nos quais é possível abrir o espaço da aula e assim ampliar a percepção do aluno. Intensificados pelo uso do advérbio "Certamente", que garante o 
estabelecimento do contrato de crença, por meio da certeza, essa abertura do espaço produz um sentido similar ao do uso da debreagem enunciativa: aproximação entre enunciador e enunciatário

Na aula 1, depois do "aviso de importância", o enunciador mantém a estratégia de nomear o enunciatário por meio de seu papel temático, de professor, mas, desta vez, o faz utilizando uma debreagem enunciva: "Para retomar o tema a ser estudado com os alunos, o professor deverá levá-los ao laboratório de informática para que, em dupla, pesquisem sobre os pronomes." (grifo nosso). Trata-se da mesma estratégia de debreagem temporal vista no plano 01, em que o enunciador instaura o momento de referência da enunciação no futuro e faz dele o agora da enunciação, a partir do qual os outros acontecimentos se desenvolvem. Essa hipótese se confirma na observação de outro período: "O professor deverá reproduzir as tirinhas da Mafalda e do Calvin e entregá-las aos alunos para, em dupla, realizarem as atividades propostas.", no qual se constata a sequência de acontecimentos a partir de um momento instaurado no futuro: (i) reprodução das tirinhas, (ii) entrega das tirinhas aos alunos, (iii) realização das atividades feita por eles.

Instaura-se também nesse enunciado um dever fazer do professor, explícito, com a finalidade de fazer o aluno fazer. Esse dever, instaurado no texto, é repetido exatamente da mesma forma nas atividades das aulas 2, 3 e 4: "o professor deverá..." seguido por um fazer: reproduzir as tirinhas para entregar aos alunos; fazer a correção oral das atividades; reproduzir o conto e solicitar aos alunos que respondam às questões. Instaura-se assim no texto uma presença forte, porque reiterada, do caráter deôntico da prescrição das atividades.

A aula 2 traz quatro tirinhas, uma de Mafalda e três de Calvin e Haroldo, para análise. Todas elas são acompanhadas de perguntas que deverão ser respondidas pelos alunos em duplas. As perguntas são feitas em debreagem interna, fazendo a fusão de enunciador e enunciatário do plano, instaurando um interlocutor que tem por interlocutário um sujeito revestido de papel temático de aluno:

\section{Sobre a tirinha 1 da Mafalda:}

a. Identifique o pronome demonstrativo usado na tirinha.

b. Qual é o referente desse pronome no texto?

c. O pronome "esse" pode ser substituído por "este", sem alteração de sentido? Explique. 
d. De acordo com norma padrão, como deve ser o emprego dos pronomes demonstrativos em relação ao espaço, isto é, quando o pronome é empregado para representar a posição do objeto em relação ao falante?

e. O pronome demonstrativo na tirinha foi empregado de acordo com a norma padrão? Explique. (negrito no original)

Este plano de aula não traz respostas às perguntas colocadas, deixando para seu destinatário encontrá-las por si. São perguntas simples, que abordam estritamente a questão do uso dos pronomes e a ausência de respostas faz parecer que se propõe espaço para que o destinatário faça um ajustamento da aula ao seu conhecimento e à sua realidade. No entanto, trata-se de uma abertura muito pequena, pois a tarefa que lhe é relegada não requer grande esforço ou especialidade.

Para a aula 3, propõe-se a correção das atividades das aulas anteriores. "O professor deverá fazer a correção oral das atividades, aproveitando o momento para tirar dúvidas dos alunos." é tudo o que se enuncia como instrução para essa aula. Enuncia-se um dever fazer do professor, acrescentando-se o modo como deve ser feito (oralmente) e, em concomitância temporal, seu aproveitamento ou melhor uso: ao mesmo tempo, corrigir e tirar dúvidas. Ao prever uma aula inteira para a correção, entende-se que essa atividade está valorizada positivamente.

A aula 4 traz um conto de Rubem Braga chamado "A partilha". Trata-se de um conto que traz um narrador em primeira pessoa que está fazendo uma partilha das coisas da mãe com o irmão mais novo. Há vários subentendidos e o final do conto não é claro quanto ao destino dos irmãos e ao uso do canivete que eles disputam, deixando espaço aberto para a interpretação do leitor. As questões sobre o conto, no entanto, versam exclusivamente sobre o uso de pronomes: de tratamento, possessivos e demonstrativos. Como na aula 2, as questões são dirigidas ao aluno em debreagem interna, produzindo a fusão entre enunciador e enunciatário e efeito de realidade, por remeter a um simulacro da aula.

Tem-se, para este plano de aula, uma debreagem espacial enunciva, com a instauração de um não-aqui que irá acompanhar esse sujeito ele - revestido como "o professor" - nesse tempo do enunciado posterior ao da enunciação. Há uma indicação de espaço tópico que aparece duas vezes: na seção "Estratégias e Recursos da Aula" e na primeira atividade da aula 1 , reproduzida a seguir. 
Para retomar o tema a ser estudado com os alunos, o professor deverá leválos ao laboratório de informática, para que, em dupla, pesquisem sobre pronomes. (negrito nosso)

Essa indicação do "laboratório de informática" como lugar onde acontecerão as atividades de pesquisa contribui para a composição da isotopia do uso da tecnologia digital nas aulas. Não aparece neste plano a figurativização espacial "sala de aula".

Olhando-se de uma maneira mais ampla para este plano de aula, tem-se como textos, para se trabalhar os pronomes, três tirinhas e um conto. A primeira tirinha, da Mafalda, fala sobre o vocábulo "indicador" de modo polissêmico: ela começa falando do dedo indicador, primeiro do dela mesma e depois do do "patrão", e termina se referindo ao "indicador de desemprego", ligando-o ao dedo do patrão que aponta para a rua e despede os trabalhadores. Coloca-se uma oportunidade de problematizar as diferentes isotopias em que Mafalda coloca um mesmo vocábulo, construindo dois percursos temáticos bastante diferentes, sendo o segundo percurso político-social, oportunidade de discussão para os alunos ou mesmo de provocação para seu uso. O plano de aula, no entanto, escolhe se ater ao uso dos pronomes, objeto da aula, desconsiderando a isotopia de cidadania e política. Isso caracteriza a aula como mais fechada e menos extensa, e também de intensidade átona, por não propor a discussão de temas mais amplos. As segunda, terceira e quarta tirinhas trazem o personagem Calvin, que propõe questões outras também, tais como sua reação à possibilidade de ter um irmãozinho, seu exagero em relação à importância do próprio papel na peça de teatro da escola e como se constrói o humor pelo cruzamento de diferentes isotopias a partir de "chorar" (chorar pela dramaticidade do teatro vs. chorar porque está cortando cebolas), além de uma questão sobre a culpa. $O$ enunciador escolhe, porém, manter-se restrito ao assunto principal da aula: pronomes. Por fim, o último texto, o conto de Rubem Braga, não é de fácil compreensão para os alunos, por ser enigmático quanto aos subentendidos que propõe para sua interpretação. Apresenta-se como texto, no entanto, com a única finalidade de interpretação dos pronomes, sem apontar caminhos para exploração de sua complexidade.

Quanto a essa não abertura do texto para os temas que aparecem no material analisado e que poderiam ter sido tratados na aula, pode-se considerá-la de duas maneiras. Por um lado, podemos compreendê-la como indo no sentido contrário do que o item Avaliação, desse mesmo plano de aula, estabelece: uma abertura para o universo linguístico 
e comunicativo. Parece que, no momento de o enunciador abrir o seu universo e introduzir elementos que poderiam enriquecer a aula, ele opta por se restringir, preferindo não ampliar a relação e a aproximação entre os textos e o mundo dos alunos. Por outro lado, pode ser apontada como um ponto positivo a não dispersão do assunto da aula em temas outros. Tendemos, no entanto, a mais lamentar do que louvar o que apontamos como um fechamento do plano para esses temas transversais, cuja abordagem é prescrita pelos PCN. Por fim, podemos fazer uma terceira consideração quanto à não abertura da discussão nesse plano de aula. Pode-se pensar que, como faz o plano de aula 02, entra-se na esfera do "não dito", "não tratado", porém presente no plano, com minimização do risco de rejeição ao seu uso. Tem-se, assim, uma estratégia de manipulação que leva o destinatário a aderir ao plano de aula mesmo que não deseje tratar dos temas de discussão que nele estão contidos.

Tem-se, em síntese, no plano de aula 03, Coesão textual: o pronome na construção do texto: para o tempo, o uso da debreagem enunciva que utiliza o futuro como momento de referência da enunciação; para pessoa, os empregos alternados de usos de debreagem enunciva e de debreagem enunciativa em que se interpela o professor por meio de vocativo; para o espaço, a utilização da debreagem espacial enunciva. O plano, como os anteriores, traz os objetivos descritos utilizando verbos no infinitivo. Há referências externas para pesquisa sobre o assunto, boa marcação visual da organização do plano em aulas e a utilização de debreagem interna para se dirigir ao aluno.

\subsection{Análise do plano de aula 04 - Publicando com Cecília Meireles.}

Trata-se de um plano de aula publicado em setembro de 2008, de autoria de Eliane Candida Pereira, da Universidade de São Paulo, SP. Essa aula tinha quase 27 mil acessos em setembro de 2016, 20 classificações de 5 estrelas e 24 comentários de usuários. Ela compõe este corpus porque integra uma Coleção de Aula, que são aulas selecionadas pelo MEC e agrupadas sob um mesmo tema, no Portal, a fim de facilitar sua consulta e utilização pelos usuários. A escolha de uma aula para compor uma coleção, feita pelo MEC, reforça sua 
identificação como uma aula que o Ministério autoriza e sanciona como "boa aula". A autoria da seleção é do Ministério da Educação - DF e seu tema é "Textos Literários". Ela foi criada em novembro de 2014. Essa coleção é composta por 10 aulas e esta é a única destinada ao ensino fundamental final, razão pela qual foi escolhida para esta análise.

A aula apresenta como objetivos ("o que o aluno poderá aprender com esta aula"): “Conhecer as características da poesia: organização textual, rimas, ritmo; desenvolver habilidades de leitura, interpretação, reflexão e expressão oral; desenvolver a atitude de colaboração." Do mesmo modo que os planos anteriores, enunciam-se os objetivos utilizando verbos no infinitivo, construindo um efeito de duratividade. Observamos também que "conhecer", como objetivo de aprendizagem conforme a Taxonomia de Bloom, é bastante átono, pois está no primeiro degrau da escada de construção do conhecimento. Para conhecimentos prévios, o plano de aula coloca apenas: "Faça um levantamento sobre o que os alunos já sabem a respeito sobre [sic] poesias: sabem alguma coisa de cor ou reconhecem algum autor?".

A descrição das "Estratégias e Recursos da Aula" mostra uma divisão bem marcada subdividida em quatro etapas que têm nomes que as explicam: 1a etapa-Conhecendo Cecília Meireles; 2aㅡ etapa - Escrevendo com Cecília Meireles; 3a etapa - Lendo com Cecília Meireles; e 4a etapa - Publicando com Cecília Meireles. Há um crescendo em complexidade das tarefas de cada etapa, percebidas por meio desses nomes, o que também nos remete à Taxionomia de Bloom, que atesta essa crescente complexificação. "Conhecer" Cecília Meireles, no primeiro degrau da escada; "Escrever", já demonstra aplicação, no terceiro degrau da escada, e "Lendo" e "Publicando", ambos como sinônimo de produção de conhecimento, que se encaixa no penúltimo degrau da escala taxonômica, denominado "Síntese". De modo resumido, o plano de aula solicita que os alunos conheçam um poema de Cecília Meireles, depois pesquisem outros poemas seus, escrevam poemas ou textos em prosa a partir dos poemas, gravem esses poemas em audiolivros e, por fim, compartilhem essas gravações em sites de armazenagem de conteúdo. O uso do gerúndio no nome das etapas - conhecendo, escrevendo, lendo, publicando - evidencia o aspecto durativo do verbo, o que parecer construir como efeito a duração dos resultados das ações propostas - valor que o enunciador, inserido no cenário educativo escolar, quer transmitir ao enunciatário como eufórico. 
A seção Estratégias e Recursos da aula inicia-se assim:

1a Etapa:

Conhecendo Cecília Meireles...

Para iniciar as atividades, o professor lê para os alunos a poesia 'Ou isto ou aquilo', de Cecília Meireles.

[segue o poema]

Provoca-se que comentem sobre o conteúdo apresentado e as escolhas que permeiam nosso cotidiano. Em seguida, para que os alunos conheçam a autora propõe-se que vejam o vídeo Cecília Meireles e façam anotações sobre sua vida e obra.

Verifica-se o uso de debreagem enunciva de pessoa no presente simples - "o professor lê para os alunos", "provoca-se que comentem", "propõe-se que". As expressões de sequenciação que aparecem nesse trecho, "Para iniciar as atividades" e "Em seguida", mostram seu desenrolar. Detemo-nos, no entanto, nessa primeira expressão, que remete a um tempo posterior ao da enunciação, a um não-agora - quando a aula irá se iniciar. Ela instaura no texto um momento de referência não-concomitante, no futuro, em vez do presente simples concomitante à enunciação, como se poderia crer observando-se apenas o tempo verbal utilizado. Constrói-se, portanto, uma embreagem de tempo, com a utilização do presente simples como presente do momento de referência futuro, o que é reforçado pela segunda expressão sequencial, "em seguida". Levantamos essa hipótese com base em Fiorin (2002: 193) que nos traz o seguinte exemplo, tirado de Machado de Assis: "Vá jantar comigo em Santa Tereza, disse Palha ao despedir-se. Não tem que hesitar, lá o espero [=esperarei]." Esse exemplo mostra que esse tipo de embreagem é possível, e também demonstra que, para o interlocutor, a presença do interlocutário em Santa Tereza não estava na ordem da possibilidade, como normalmente acontece quando se usa o tempo futuro, mas da certeza. Entretanto, para se poder afirmar que se trata de uma embreagem, é necessário que tenha sido deixado no enunciado uma marca discursiva da debreagem anterior, conforme afirmam Greimas e Courtes no Dicionário de Semiótica (s/d [1979]: 119 apud Fiorin, 2002: 193). Olhamos, assim, para a expressão incoativa "Para iniciar as atividades...", que avisa que o que vem a seguir tem a finalidade de começar alguma coisa, ou seja, se situa no futuro, deixando entrever a debreagem enunciva anterior que instaurava o tempo no futuro do presente e que faz com que se possa compreender esse enunciado como equivalente a "Para iniciar as 
atividades, o professor lerá para os alunos...". Com isso, o enunciador constrói como efeito de sentido o transporte do enunciatário para o momento da aula, futuro, apresentando-lhe os personagens professor e aluno no cenário da sala de aula e dizendo o que acontece como quem faz uma profecia e, mais ainda, com o efeito de certeza do acontecimento (FIORIN, 2002: 212). Por isso, pode-se afirmar que se tem instaurado o momento de referência da enunciação no futuro, o que também é encontrado nos planos de aula 01 e 03, embora neste caso haja a diferença de sua construção por meio de uma embreagem. O uso da embreagem faz com que o "então" torne-se um "agora" e o "lá" da sala de aula torne-se um "aqui".

Trata-se também de um texto marcado por conjunções de finalidade “... para que os alunos conheçam a autora...", "É preciso instigá-los [...] Para isso faz-se ...", "Para isso há serviços gratuitos na internet..." (grifos nossos). Assim, constrói-se uma clareza na visualização dos objetivos da aula e do encadeamento das atividades, além da explicitação da finalidade das atividades. Também se observa tratar-se de um plano cuja tonalidade deôntica apresenta-se mais átona, pelo abundante uso de sugestões e propostas, embora apareçam, como no exemplo trazido neste parágrafo, expressões como "é preciso".

Em todas as quatro etapas do desenvolvimento da aula é utilizada a mesma estratégia discursiva: debreagem enunciva de pessoa com efeito de impessoalidade e embreagem enunciva de tempo, utilizando o tempo presente no lugar do futuro para descrever o desenrolar da aula. A terceira etapa, na qual se pede que os alunos gravem um livro falado, inicia-se assim:

Para divulgar as obras de Cecília Meireles, bem como as poesias produzidas a partir delas, os alunos devem ser convidados a gravarem um livro falado. Audiobook, audiolivro ou livro falado é uma "gravação dos conteúdos de um livro lidos em voz alta".

E em seguida há instruções passo a passo sobre como acessar o gravador do computador para que os alunos possam gravar suas leituras do texto. Esse trecho traz um exemplo bastante claro do uso que o plano de aula faz do que se pode chamar de construção didática do discurso: a repetição de um mesmo termo com sinônimos-audiobook, audiolivro ou livro falado - o significado desses termos trazido entre aspas, como se retirado de um dicionário e, depois, a explicação pormenorizada de como acessar o recurso do gravador que deve estar presente no computador de todas as escolas. 
Na quarta etapa, "Publicando...", solicita-se que esses áudios sejam divulgados em sites de hospedagem e de compartilhamento de conteúdo vigentes à época, junto com instruções de como fazê-lo. Há pequenas pontuações sobre a condução da aula, como "O professor deve provocar a revisão do material produzido, lembrando-os [sic] que o ritmo será essencial durante a leitura.". Durante as instruções, alternam-se os usos de dever, "os alunos devem ser convidados a gravarem um livro...", com usos de "poder" indicando possibilidade ou proposta, "Pode-se sugerir que coloquem...". Essa alternância cria um efeito de abrandamento da prescrição de atividades propostas pelo plano de aula. O uso de algumas construções no subjuntivo também ajuda a criar esse efeito, como "para que os alunos conheçam", "propõe-se que vejam", entre outras.

A debreagem espacial é também enunciva, situando-se em um não-aqui do enunciador. Encontra-se, neste plano, um revestimento semântico do espaço no trecho seguinte:

É preciso instigá-los a conhecer outras poesias de Cecília Meireles. Para isso faz-se a organização de grupos de trabalho para que pesquisem outras poesias da autora na biblioteca da escola ou na biblioteca pública. Na aula seguinte, organiza-se uma roda de leitura com as poesias encontradas pelos alunos.

Nessa menção à biblioteca (da escola ou da comunidade), o enunciador remete o espaço da enunciação para fora da sala de aula ou da escola, mostrando uma abertura do espaço em direção ao exterior.

Pensando-se na escolha deste plano de aula para integrar uma coleção montada pelo MEC, fica claro que foi privilegiado o conteúdo instrutivo de uma tecnologia inusitada - o uso do gravador para produção e posterior divulgação de um audiolivro de poemas na internet para produção de uma aula que saísse do comum, como pede o tutorial de criação de aulas do Portal. Há referências claras sobre como gravar, onde hospedar, onde olhar, na internet, por outras referências. Produz-se assim um percurso temático da tecnologia, da novidade, da criação e da publicação de conteúdo, o que é bastante desejável de acordo com os PCN e com o Portal do Professor.

Trata-se, em resumo, de um plano de aula que apresenta uma estratégia discursiva de uso da debreagem enunciva para o tempo, mostrando o futuro como momento de referência 
por meio de uma embreagem de uso do presente pelo futuro do presente. Para pessoa, temse o uso de debreagem enunciva, bem como para o espaço. O plano apresenta caráter deôntico mais tênue, percurso temático de uso de novas tecnologias e abertura para referências externas tanto em relação ao espaço "físico" quanto digital, com um direcionamento do aluno para fora da sala de aula e algumas indicações de endereços da internet para consulta.

\subsection{Análise do plano de aula 05 - Debate Deliberativo sobre Bullying}

Quando aplicados filtros de busca utilizando-se os critérios de aulas mais bem classificadas e aulas mais relevantes, tanto em 2015 quanto em 2016 (em mais de um momento ao longo desses anos), os resultados foram iguais: a aula "Debate Deliberativo Sobre Bullying" apareceu em primeiro lugar. Trata-se de uma aula de autoria de Rosângela Ferreira Luz, da Escola Municipal Clori Benedetti de Freitas, em Dourados-MS, publicada em 24/09/2009, classificada com 5 estrelas, com dez comentários e mais de 16 mil acessos em agosto de 2015 e mais de 21 mil acessos em janeiro de 2019.

A aula apresenta como objetivos, na seção "O que o aluno poderá aprender com esta aula":

O aluno aprenderá a organizar e analisar os dados de pesquisa, selecionando artigos e depoimentos que sejam úteis para a apresentação do trabalho em forma de debate. Sua pesquisa deverá ser salva no blog individual criado pelo aluno para difundir o tema na rede, para discussão e reflexão, aprenderá também a elaborar o discurso oral e escrito, usando expressões adequadas a um debate deliberativo, apresentando argumentos que embasem a posição tomada e com sugestões coerentes para serem colocadas em funcionamento dentro da comunidade escolar, tão logo findem as atividades em sala sobre o assunto. Aprenderá a perceber e utilizar a concordância verbal e nominal para clareza do material produzido. E também se sentirão valorizados, elevando a autoestima ao repassar as informações à [sic] toda escola.

E prescreve que esse conteúdo seja trabalhado em 10 aulas de 50 minutos. 
A primeira questão a chamar nossa atenção é a completude da descrição de objetivos de aprendizagem desse plano, que bem poderia ser denominado projeto em vez de aula. Tem-se objetivos individuais e coletivos, que estabelecem relações pessoais (discussão, discurso oral, debate, disseminação de informações para toda a escola) e relações na rede (produção de blog para divulgação do tema na rede). Prescreve-se um ciclo completo de aprendizado: coleta, organização e análise de dados sobre o assunto; apresentação de trabalho em forma de debate e criação de blog para difusão do tema na rede, ou seja, difusão de informações dentro do espaço escolar (espaço interno, próximo) e fora (espaço externo, distante); no que diz respeito à apresentação, abarca as modalidades orais (debate) e escrita (blog); trabalho coletivo (debate, sugestões para funcionamento dentro da comunidade escolar) e trabalho individual (analisa, cria, faz concordância nominal e verbal, tem a autoestima elevada). Mostra-se complexidade em se juntar os contrários em um mesmo lugar (oral e escrito, dentro e fora da escola, individual e coletivo). As atividades propostas aparecem qualificadas positiva e significativamente: os artigos e depoimentos são "úteis", as expressões são "adequadas a um debate deliberativo", os argumentos "embasam a posição tomada", as sugestões são "coerentes". Diferentemente dos planos anteriores que enunciaram os objetivos com o verbo no infinitivo e em frases sucintas, este plano de aula estabelece os objetivos utilizando o futuro do presente em períodos completos e bem desenvolvidos, em debreagem enunciva.

Cabe notar, no entanto, que nenhum dos objetivos listados relaciona-se ao tema da aula, o bullying, ou ao que fazer para diminuir o bullying na escola. Essa descrição de objetivos tem seu foco nas atividades da aula em vez de em seu assunto e por isso poderia ser utilizada para tratar de muitos outros temas sobre os quais se desejasse fazer uma pesquisa, debater e divulgar informações.

Nota-se também que este plano trabalha o eixo da temporalidade da aula de modo bastante abrangente, apresentando três momentos de atividades. No centro delas está o evento do debate deliberativo, no momento anterior ao debate há a preparação para ele e, no momento posterior, a disseminação dos resultados e o efeito disso sobre os alunos. Para o momento anterior ao debate, tem-se: organização e análise de dados de pesquisa, por meio da seleção de artigos e depoimentos úteis para o trabalho e o salvamento dessa pesquisa em 
um blog individual, que servirá a dois propósitos: para difusão do tema na rede e para discussão e reflexão. Para o momento do debate há uma preparação para ele, de "elaboração de discurso oral e escrito" e um detalhamento dessa elaboração: uso de expressões adequadas ao debate, apresentação de argumentos que embasem a posição, apresentação de sugestões coerentes para serem colocadas em funcionamento na comunidade escolar. Entra aqui um tópico de gramática normativa: utilização da concordância nominal e verbal, o que se parece mais com uma justificativa para que esse plano seja pertencente à disciplina de Língua Portuguesa. Para o momento posterior ao debate, tem-se o repasse das informações à escola e, por causa disso, o sentimento de valorização que os alunos terão. Trata-se, portanto, de uma descrição de objetivos que cobre temporalidade extensa (dez aulas, muitas atividades) e espacialidade extensa (dentro da escola, na comunidade, na internet), e que mostra um enunciador que tem uma visão temporal abrangente do processo, dos três momentos do debate, já mencionados.

Na sequência de apresentação do plano de aula, depois dos objetivos, encontra-se a seção "conhecimentos prévios trabalhados pelo professor com o aluno", que traz uma lista com sete itens:

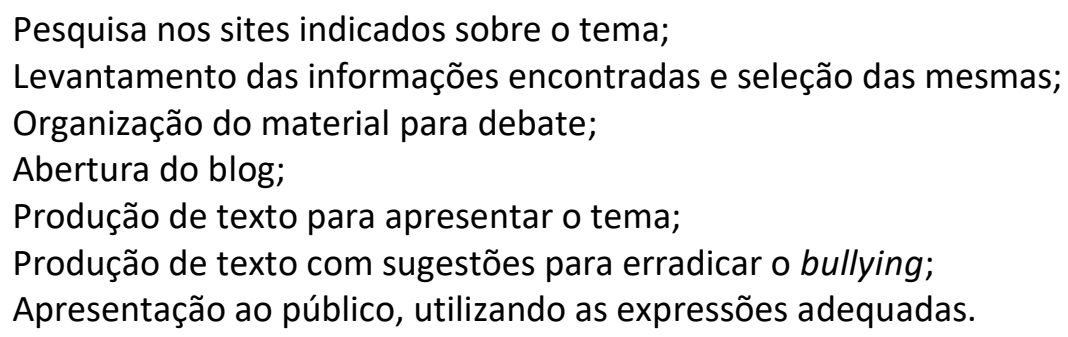

A estratégia discursiva utilizada para a seção "Conhecimentos prévios" é a debreagem enunciva, com frases nominais que criam efeito de objetividade. Apresentam-se bastante ligados aos objetivos propostos, porém, na verdade, não se trata de conhecimentos que deveriam ter sido trabalhados anteriormente, mas de descrição das etapas das atividades que irão acontecer durante a aula. Por exemplo, "pesquisa nos sites indicados" será a primeira etapa da aula. Ao elencar as atividades a serem desenvolvidas para a aula sobre bullying sob o título de "conhecimentos prévios", o enunciador mostra um descuido na elaboração do documento que produz, o que poderia prejudicar sua transformação em aula. Entretanto, uma vez que esta aula apareceu em primeiro lugar na classificação de aulas mais relevantes e 
de aulas mais bem classificadas, pode-se concluir que essa imprecisão não foi sancionada negativamente. O que se pode verificar mais claramente, dado o modo como esse enunciado está organizado, é que o conhecimento proposto nesse plano parece estender-se por todos os lados: pesquisa (lateralidade), levantamento (para cima), abertura (para fora), produção de texto para apresentação (olhar para trás, para o que foi encontrado) e produção de texto com sugestões (olhar para frente, para o futuro e o como solucionar o problema proposto). Caracteriza-se, assim, que o conteúdo do plano tem uma abrangência englobante, do mesmo modo que sua temporalidade, presente, anterior e posterior, conforme apontado acima.

O desenvolvimento das atividades propostas nesse plano se apresenta divido em duas partes, sendo que seu miolo, que contém a descrição das atividades, sua condução e os diálogos a serem utilizados com os alunos, é uma parte que estava pronta e publicada anteriormente como uma webquest no GoogleDocs (conforme informação que consta no plano). O início e o fim são a apresentação do plano de aula, do tema, e seu fechamento no formato do site Portal do Professor. O registro da língua utilizado em ambos é diferente: mais formal na parte do plano de aula e dirigida ao professor, mais informal na parte da webquest e nas debreagens internas que têm o aluno como interlocutário.

Este plano permite que se observe de modo claro a organização do tempo em torno de um momento de referência futuro. Observemos o seguinte trecho:

\section{Estratégias de Recursos da Aula}

[link para animação que não está mais disponível]

Esta animação será mostrada com o intuito de levantar a questão da exclusão social e, em seus comentários posteriores, perceberão que acontece por causa dos preconceitos cimentados em nossa formação humana.

Em seguida trabalharão com a webquest planejada por mim e publicada no Docs.google [...]. (negritos nossos)

Em "a animação será mostrada", tem-se o uso do verbo no futuro do presente, por meio do qual ainda não se pode afirmar tratar-se de um eixo de referência concomitante ou não concomitante à enunciação (conforme Fiorin, 2002: 160), uma vez que esse tempo verbal pode expressar essas duas temporalidades. No entanto, o emprego das expressões de tempo e sequenciamento de ações, "comentários posteriores" e "em seguida", introduzindo novos verbos no futuro do presente, mostram o desenrolar das ações em um "futuro do futuro". 
Portanto, pode-se afirmar que esse plano de aula, a exemplo dos planos 01 e 03, já analisados, também instaura a cena da enunciação no momento de referência não-concomitante, posterior, em uma debreagem enunciva.

Observe-se a frase final da seção Estratégias e Recursos da aula, ainda para observar as estratégias discursivas que esse plano constrói para as debreagens temporais:

Ao final do desenvolvimento da webquest, os alunos terão divulgado o tema tratado no blog da escola, onde postarão os resultados destas aulas e de outras possíveis.

Tem-se, introduzida pela expressão "ao final do desenvolvimento", uma locução verbal com o verbo "ter" no futuro, seguido do verbo divulgar no particípio, denotando o fato acabado, marcando o aspecto terminativo na conclusão deste plano de aula, com esse uso do futuro do futuro.

Quanto às debreagens actanciais, o desenvolvimento das atividades, na seção Estratégias e Recursos da aula, utiliza-se da debreagem enunciativa. Se voltarmos ao início dessa seção, já reproduzido acima, podemos observar que se inicia aparentemente sem marcas da enunciação ("Esta animação será mostrada com o intuito de..."), para, em seguida, deixar claro tratar-se de uma estratégia que acontece entre um "eu" que se endereça a um "tu" ("Em seguida trabalharão com a webquest planejada por mim...", "Veja abaixo como foi..."). Este plano de aula apresenta constantes debreagens em segundo grau, em que o enunciador se funde ao enunciatário e passa a ter por interlocutário o aluno. Por exemplo:

O aluno lerá a webquest publicada ou digitada no word.

(fala destinada ao aluno) Você sofre bullying em sua escola e não sabe o que fazer para se livrar desta vergonha e raiva que passa todo dia com alguém zombando de você?

Também é importante notar o uso de um registro mais informal ao se dirigir ao aluno:

Capriche, agora vocês serão os professores. Escolham imagens para produzir um texto chamativo para a prevenção de atitudes do MAL (bullying) em nossa escola.

Que missão espinhosa! Hein?

Essa escolha de um registro mais informal e próximo da oralidade, "capriche", "missão espinhosa! Hein?", traz para este plano de aula um efeito de aproximação entre professor e 
aluno, enunciador e enunciatário da aula. O uso de expressões como "hein", "né", típicas do registro oral, aproximam a aula de uma conversa e atenua a distância entre professor e aluno. Essa estratégia discursiva poderia ser atribuída ao fato de o enunciador crer que o enunciatário-aluno precisa desse tipo de registro para aceitar a manipulação, que ele não crê que o aluno se deixaria seduzir por um registro mais formal, não tão facilmente, pelo menos. Mas também se pode pensar que essa estratégia foi escolhida devido ao tema da aula ser tão sensível que não possa ou não deva ser tratado de forma mais distante (ou menos próxima). Essa distinção de tratamento que o enunciador faz entre o enunciatário do plano e o enunciatário da aula fica mais evidente se observarmos o uso de "você". O professor, destinatário do plano, não é tratado desse modo nenhuma vez. Já o aluno é, o tempo todo, "você". O destinador do plano está contando a seu destinatário que o destinatário dele, da aula, precisa de proximidade. Está mostrando que a estratégia para se comunicar com o aluno é outra, que não se pode usar a mesma estratégia que foi utilizada no plano, para o professor. Os outros planos de aula também se dirigem ao aluno como "você", explicitamente, em debreagem enunciativa, mas tendem a utilizar registros de linguagem mais formais.

O plano de aula 05 traz como tema central a sensibilização quanto a um tipo de exclusão social, atribuindo-a a "preconceitos cimentados em nossa formação humana", conforme enunciado no início das atividades. A escolha do lexema "cimentado" para mostrar a inserção do preconceito na essência da sociedade ("formação humana") chama a atenção para algo que se apresenta como de imobilidade empedrada, sobre a qual qualquer ação irá requerer força (porque se encontra no cimento) e percepção aguçada (porque está na "formação", no âmago, e por isso é difícil de ser notada). Mais ainda, constrói-se aí uma metáfora que aponta para um sentimento delicado que precisa ser arrancado de dentro de um bloco de cimento. A força dessa imagem, do delicado e do bruto, fazem revestir de modo muito acurado a brutalidade do bullying e a delicadeza dos sentimentos de quem o sofre, donde decorre o cuidado necessário com que deverá ser tratado. Ao mostrar que tem a percepção sobre essa dualidade, o plano de aula constrói seu fazer regido pela sensibilidade que age de modo abrangente, "por toda a escola" (como será evidenciado a seguir). Seu ponto forte é tratar de um tema que causa "vergonha e raiva", de forma a desenvolver a percepção dos alunos para tratarem dessa "missão espinhosa". Os sentimentos e ações 
sensíveis envolvidos nessa situação de exclusão social estão lexicalizados: "medo", "denúncia”, "sensibilizar e alarmar os estudantes para os efeitos nocivos do bullying". Tratase de um plano que privilegia a dimensão sensível dos alunos e que pretende, por meio dela, levá-los à ação sobre toda a escola que tenha como efeito a inclusão, contrária à exclusão social. Pensamos que essa característica seja tão forte que atenue ao máximo o equívoco de organização que apontamos na seção "conhecimentos prévios", os erros de digitação ou o fato de, dentro da webquest, nem sempre se avisar se a fala é para o professor ou para o aluno. Tudo isso fica menor perto da força sensível empregada no tratamento de um tema tão delicado e importante.

Para o tratamento do espaço, este plano faz uso da debreagem enunciva, que acompanha a debreagem temporal e a actancial do início e do fim do plano. Nota-se um percurso temático que constrói um espaço da aula expandido a toda a escola por meio das expressões "para serem colocadas em funcionamento dentro da comunidade escolar", "repassar informações a toda a escola", "ambiente escolar", "em sua escola", "em nossa escola", "divulgação das sugestões para toda a escola", que mostram como as informações circulam no espaço escolar amplo, o que reforça a extensidade desse plano. A escola fica caracterizada como uma totalidade de espaço a ser ocupado pelos alunos a partir do fazer da aula. O revestimento semântico do espaço produz uma ancoragem do plano de aula no espaço do mundo do aluno, produzindo o efeito de referenciação. Pelas inúmeras fontes de pesquisa na internet que ele traz em sua descrição de atividades, pode-se dizer que se trata também de um plano que se caracteriza, também para o "mundo digital", pela abertura no eixo da extensidade.

Um último aspecto a se considerar sobre esse plano de aula diz respeito ao item "Avaliação" que, neste caso, é apresentado durante o desenvolvimento da aula e depois aparece brevemente no item específico para avaliação, ao final do plano. Será analisado a seguir por causa dessa especificidade, ainda que essa seção não tenha sido objeto de análise nos planos anteriores. Já nos pronunciamos a respeito da pouca valorização eufórica atribuída à avaliação nos planos de aula, começando pelo pequeno espaço dedicado a ela no tutorial do Portal do Professor analisado no capítulo 1 desta tese. Mas, neste plano, a avaliação é um item bastante desenvolvido, tendo uma parte voltada para o aluno se autoavaliar, 
especificando parâmetros a serem observados, e outra parte para o professor avaliar o aluno, essa um pouco mais genérica, mas, mesmo assim, significativa. O tipo de avaliação proposto nesse plano é o que mais se aproximaria de algo que poderíamos chamar de "boa avaliação" (parte importante de fechamento da "boa aula") por ser clara e objetiva. A avaliação voltada para os alunos, na parte central, evidencia para eles o que se avalia positivamente por meio da utilização dos critérios "iniciante", "profissional", "mestre no assunto". Elencam-se itens como: contribuição com o grupo, comprometimento, respeito à opinião dos colegas, imposição da própria opinião, apresentação etc. Isso é positivo porque constrói com clareza os parâmetros de sanção para os alunos e ajuda o professor a direcionar o seu olhar para o que é importante. Na parte de avaliação voltada para o professor, tem-se:

\footnotetext{
Avaliação

A avaliação será feita de acordo com a produção, engajamento dos alunos no desenvolvimento e apresentação do resultado de pesquisa, sempre observando se o aluno será capaz de:

Demonstrar compreensão de textos orais, nos gêneros previstos para as aulas, por meio de retomada de tópicos dos textos;

Atribuir sentido a textos orais e escritos, posicionando-se criticamente diante deles;

Selecionar procedimentos de leitura adequados a diferentes objetivos e interesses (estudo, formação pessoal, realização da tarefa) e as características do gênero e suporte.
}

Note-se que a avaliação abrange, na primeira linha, os três momentos propostos pelo plano de aula (produção, desenvolvimento, apresentação dos resultados) para, em seguida, detalhar o que deve ser observado nesses momentos. Note-se ainda que essa observação se dá sobre itens como: "demonstra compreensão...", "atribui sentido...". Trata-se de características da ordem do sensível a serem apreendidas como resultado do desenvolvimento da aula, o que nos leva a classificar este plano como fora do padrão estabelecido pelos quatro planos anteriores, que não adentram essa dimensão. É bastante provável que se deva também a essa característica a classificação deste plano em primeiro lugar entre os "mais relevantes" e os "mais bem classificados".

Quanto aos percursos figurativos e temáticos construídos pelo plano de aula, pode-se apontar ainda a prescrição abundante do uso de tecnologia digital em sala de aula: assistir a uma animação sobre o tema, pesquisa [na internet], criação de blog... E o fato de ele trazer as 
fontes para essa pesquisa, o que nos leva a duas possibilidades de interpretação diferentes: (i) pode ser que houvesse poucas fontes na época (2009), daí a necessidade de apontá-las; (ii) ao trazer as fontes, o plano ajuda a assegurar que seu destinatário encontre a informação necessária para realizar a tarefa proposta para auxiliar o enunciatário nesse universo "novo" que era a pesquisa na internet em 2009, e também pode significar um cuidado do enunciador para que o enunciatário entre em conjunção com esse objeto desejado.

Temos, em resumo, no quinto plano de aula analisado, o uso da debreagem temporal enunciva com a instauração do futuro como momento de referência da enunciação, o uso de debreagem actorial enunciativa com várias ocorrências de debreagem em segundo grau. Este plano apresenta um grande número de revestimentos semânticos para o espaço escolar, abrangendo-o de modo amplo e também uma grande extensidade de fontes de consulta que o fazem abrir-se para além da aula. Traz em destaque o amplo uso de debreagens de segundo grau, dirigindo-se ao aluno utilizando um registro mais coloquial de linguagem.

Diferentemente dos planos anteriores, nesse plano não há a ocorrência do vocativo "professor" ou do uso de "professor" como sujeito da oração. Nos outros planos, quando essa estratégia foi utilizada, julgou-se que seu efeito de sentido tenha sido de aproximação, de identificação que cria laço entre enunciador e enunciatário. No caso deste plano, que trata de temas sensíveis, essa estratégia não parece ter sido necessária, porque o próprio tema e o modo de abordá-lo já geram, por si, esse efeito. Pode-se, ainda, nessa mesma direção, dizer que se trata de um plano cujo caráter é mais volitivo do que deôntico, pois apresenta pouquíssimas ocorrências da palavra "dever".

\subsection{Análise do plano de aula 06 - As várias facetas de Machado de Assis}

Trata-se de um plano de aula publicado em 24 de outubro de 2008 e que aparece em segundo lugar na lista dos planos "melhor classificados", tanto na filtragem feita em 2016 quanto em 2019. Foi elaborado por Grace Luciana Pereira, da Universidade de São Paulo, SP, 
e tinha pouco mais de 3.600 acessos em 2016 e de 5.400 acessos em dezembro de 2019 . Possui apenas dois comentários, ambos classificando-o como cinco estrelas.

Trata-se de um plano de aula breve, que ocupa pouco mais de meia página, na qual se inclui a foto da elaboradora do plano e nenhuma outra imagem (em contraste com todos os outros planos, que contêm alguma). Os objetivos são enunciados com os verbos no infinitivo, como acontece nos demais planos, o que o insere no padrão dos outros que foram analisados: "Conhecer vários contos de Machado de Assis; Comparar as histórias e seus entrelaces. Compartilhar histórias e opiniões sobre a obra do autor estudado." Os verbos utilizados nos enunciados para essa seção aparecem em um movimento que se abre do individual, um sujeito que vai "conhecer" um objeto, para o coletivo, "compartilhar", em que um sujeito interage com outros, lhes apresenta seu objeto e é apresentado aos deles. Trata-se de verbos que ainda se localizam mais nos primeiros degraus da Taxonomia de Bloom, mas esse movimento de compartilhamento do saber e das próprias impressões é valorizado como positivo, porque enunciado como objetivo da aula, e provoca como efeito um aprendizado mais intenso.

Para a seção "Conhecimentos prévios trabalhados pelo professor com o aluno", o enunciador coloca: "O que eles sabem sobre a biografia de Machado de Assis e sua obra. A entonação necessária para uma leitura coletiva." Essa segunda solicitação pode ser entendida como um pedido por boa capacidade de leitura, suficiente para que se leia em voz alta e se acompanhe essa leitura em grupo. Também se destaca que não se solicita ao enunciatário que tenha trabalhado fatos da biografia do autor e sua obra, mas que se trabalhe "o que eles sabem", presumindo que os alunos já conheçam algo sobre o autor. A debreagem enunciva, utilizada nas duas seções acima, constrói o efeito de objetividade.

A seção Estratégias e Recursos da aula traz enunciado em seu início "Sequência Didática", que é um nome bastante usado para a descrição das atividades de uma aula no meio pedagógico / escolar. Pode-se atribuir seu uso ao fato de se recorrer a um sinônimo de "plano de aula", em substituição à "sugestão de aula" que é como se chamam os planos que temos analisados, no site. Tem-se debreagem actorial enunciativa com verbos no imperativo. Observe-se o início desta seção: 
Disponibilize o recurso de vídeo que apresenta a biografia de Machado de Assis.

[ícone com link para o vídeo]

Leia um trecho do seu livro favorito de Machado de Assis e compartilhe com os alunos o porquê dele ser seu preferido. Para seduzir os alunos é necessário que o professor tenha sido seduzido antes, portanto leia, estude, descubra o que mais lhe agrada na obra deste grande autor.

$\mathrm{Na}$ terceira frase, o enunciador recorre a uma embreagem enunciva, substituindo o "tu" por "professor", que faz evocar o enunciatário por meio de seu papel temático. Essa embreagem aparece junto com a informação de que, para seduzir os alunos, ele precisa ter sido seduzido antes. Assim, a invocação do papel temático é parte da estratégia de manipulação por sedução: se você, o professor, tiver sido seduzido, o aluno também o será. Tem-se, assim, claramente explicitado neste plano de aula, o fazer de um destinadormanipulador que age sobre o seu destinatário para levá-lo a querer-fazer. Seu fazer persuasivo é propor que um autor tão conhecido como Machado de Assis (tanto que nos conhecimentos prévios pede-se "o que se sabe sobre ele", em vez de apresentá-lo) precisa ser trabalhado por alguém que tenha sido seduzido por ele, que tenha ultrapassado a impressão do senso comum escolar de que ele é "de difícil leitura". Se o destinatário, em seu fazer interpretativo, aceitou esse contrato fiduciário que lhe está sendo proposto, ele estará competencializado para exercer esse fazer.

Para o espaço enunciativo, tem-se uma debreagem enunciativa, pois se utiliza o enunciador como referência, e ele se coloca como um ego, portanto, em um aqui e agora. Não há indicações de revestimento semântico do espaço nesse plano de aula.

Trata-se de um plano que indica fontes externas de consulta na internet. Ele traz um link para um vídeo que apresenta a vida e as principais obras de Machado de Assis e diversos links para o site Domínio Público e outros que contêm contos ou romances de Machado. Temse, portanto, neste plano, um movimento de abertura para fora da sala de aula, para o mundo virtual, com a finalidade de se buscar conhecer a obra do autor, caracterizando um movimento do saber que se expande em abertura, deslocando-se da interioridade da aula para a exterioridade do mundo. Não há indicação de divulgação para a comunidade, mas se indica a criação de um sarau e muitas trocas entre os alunos, o que aponta para um movimento de circulação do conhecimento no espaço da aula. 
A construção de um percurso temático de prazer, de aproveitamento, é clara: "livro favorito", "preferido", "para seduzir os alunos", "o que mais lhe agrada". Esse percurso, parte da estratégia de sedução deve, segundo o plano, ir na direção da sedução do professor para si mesmo, por meio do conhecimento da obra de Machado, e depois do professor para o aluno, em relação à obra. Pode-se levantar a hipótese de que se deva a esse percurso temático a boa avaliação desse plano e também sua qualidade de ser breve, como apontamos logo no início: uma vez aceito o contrato de sedução, aumentam as probabilidades de uma "boa aula".

A distribuição do conteúdo por cada aula (o plano sugere que esse conteúdo seja executado em cinco aulas) não é explicitada, não se usam palavras de sequenciamento nem indicação de qual parte será trabalhada em qual aula. Não se constrói, assim, um percurso de sequenciação, como encontrado em outros planos. Também se observa tratar-se de um plano que mais sugere do que prescreve, com uso de "proponha", "oriente", o que o caracteriza por um acento mais volitivo do que deôntico.

Tem-se, em síntese, no sexto plano de aula analisado, a construção do efeito de sentido de durabilidade por meio da proposta de objetivos com verbos no infinitivo, a utilização de debreagem temporal, actorial e espacial enunciativas, e uso de verbos no imperativo. Não se usa o futuro como momento de referência e não há alternância do uso das pessoas do discurso. Apresenta um acento átono no dever e no uso mais pronunciado de lexemas ligados à sugestão em vez da prescrição de atividades. Explicita-se a manipulação do destinatário pelo destinador com a construção de um percurso temático do prazer como meio que leva ao aprendizado, o que não foi encontrado em outros planos de aula.

\subsection{Análise do plano de aula 07 - Lições de língua crítica e culta}

Este plano de aula compõe este corpus porque aparece como resultado de pesquisa entre os dez "mais comentados" e também no resultado dos dez "mais relevantes", com 41 
comentários e mais de 17 mil acessos em janeiro de 2019. Foi elaborado por Taciana Raquel Fiorentin Calza, de Rondinha, RS, e publicado em setembro de 2009.

Como objetivo, propõe-se:

- Interpretar diferentes tipos de textos;

- Interagir e redigir;

- Criticar.

Trata de um plano que traz título e objetivos propostos bastante generalistas, que não permitem que se tenha uma ideia mais precisa do que será feito na aula. Como duração das atividades, prescrevem-se sete aulas. Solicita-se como conhecimentos prévios: "Habilidade básica de leitura; Interpretação e redação", também de modo genérico.

Como estratégias e recursos da aula, na descrição das atividades, tem-se primeiramente uma lista das estratégias a serem utilizadas ("uso da internet, material de uso diário, trabalho em grupo, trabalhos individuais") e depois se descreve o desenvolvimento da aula segmentado em oito atividades. Em resumo, trata-se de, primeiramente, uma leitura da letra da música, "Cidadão", de José Ramalho, com dramatização e discussão de seu conteúdo. Depois assiste-se a vídeos do YouTube relacionados a ela e em seguida os alunos respondem a questionamentos propostos pelo professor a respeito de exclusão social. Na sequência, os alunos devem ouvir "Asa Branca", de Luiz Gonzaga, e transcreverem-na para a norma culta da língua portuguesa. Por fim, devem pesquisar na internet e discutir o que caracteriza uma boa redação para, por último, fazerem a produção de uma redação sobre o tema exclusão social.

Este plano, assim como o plano 05, traz um grande número de atividades e visa a discussão e produção sobre o tema da exclusão social. Aquele, no entanto, é mais detalhado na descrição dos objetivos, coloca mais claramente o que está programado para as aulas desde o início. Este vai revelando seu conteúdo conforme se apresentam as atividades. Ambos propõem um conteúdo extenso para ser trabalhado em várias aulas.

Para a análise das estratégias discursivas utilizadas neste plano, reproduzimos alguns enunciados para que possamos observar neles as escolhas do enunciador. A seguir, o início da descrição das atividades:

ATIVIDADE I

$[\ldots]$ 
Esta aula terá como primeira atividade a leitura (oral, visual e auditiva) da letra da música Cidadão de Zé Ramalho:

Na sala de aula o(a) professor(a) deverá explicar aos alunos o que eles irão fazer no Laboratório de Informática. [...]

A leitura poderá ser feita individualmente ou dependendo do tamanho da turma e número de computadores poderá ser desenvolvida em duplas, trios...

Em seguida divida os alunos em grupos para que, após a leitura, façam a dramatização da letra da música. [...]

ATIVIDADE II -

Agora, oriente os alunos para que acessem os endereços eletrônicos abaixo e assistam aos vídeos publicados no youtube sobre a música: Cidadão de Zé Ramalho disponíveis nesses endereços eletrônicos: [...].

$[\ldots]$

ATIVIDADE VIII

Agora cada estudante criará sua própria redação abordando o tema: exclusão social - causas e consequências e observando todos os prérequisitos tratados nas atividades anteriores, principalmente a utilização da norma culta da Língua Portuguesa. (negritos nossos)

Quanto à estratégia discursiva temporal, observa-se que ela se caracteriza pelo uso alternado de duas formas distintas: uma debreagem enunciva com a utilização dos verbos no futuro do presente ("terá", "deverá explicar" etc.) e uma debreagem enunciativa com os verbos no presente do imperativo ("divida", "oriente"). Essa alternância, junto com os advérbios de tempo ("em seguida", "agora" (1a ocorrência)) que introduzem os verbos no presente do imperativo, constrói nossa hipótese de que se tem a instauração do futuro como momento de referência não concomitante ao momento da enunciação, como explicado na análise do plano de aula 01 . Tem-se que este plano faz uso da debreagem enunciva no tempo não-concomitante posterior, futuro, e que os verbos no imperativo presente podem ser lidos como embreagens enunciativas. Essa estratégia é utilizada do início ao fim do plano, como se pode ver pela atividade oito, também reproduzida no trecho acima, que mostra o uso do advérbio de tempo "agora" precedendo o verbo no futuro do presente - esse "agora" significa o tempo da última atividade que está planejada para ser desenvolvida na aula, ou seja, na sequência das outras, portanto trata-se de um "agora" no futuro. Desse modo, este plano constrói seu efeito de predição da aula, acentuando o efeito de certeza de realização do acontecimento futuro. 
Para a debreagem actorial, nota-se o uso alternado de debreagem enunciva e enunciativa. Para demonstrá-lo, voltamos ao enunciado da atividade 1, que traz: "Já no Laboratório da Informática o(a) professor(a) deverá orientar os alunos" e "Em seguida divida os alunos em grupos para que, após a leitura, façam a dramatização da letra da música." (grifos nossos). Tem-se, nesses trechos grifados, primeiramente o uso da debreagem enunciva, nomeando o enunciatário em seu papel temático e, em seguida, a mudança de estratégia para o uso de uma debreagem enunciativa, com o uso de um verbo no imperativo (ambos em negrito). Essa mesma estratégia é utilizada em outro momento, conforme abaixo:

\section{ATIVIDADE III}

Após eles assistirem aos vídeos reúna-os em duplas e oriente-os para que façam uma reflexão com o(a) colega de turma. Oriente-os para que discutam sobre o conteúdo das imagens dos vídeos e o conteúdo da letra da música. Na sequência o professor fará questionamentos aos alunos para que reflitam sobre o que leram e o que assistiram. (grifos nossos)

Este plano também interpela o professor por meio de um vocativo. Na atividade VI:

Professor, o objetivo destas atividades listadas acima é o de oportunizar aos estudantes o contato com outros tipos de textos [...].

Essa alternância entre as debreagens actoriais, acrescida do uso de um vocativo para chamar o professor, também aparece nos planos 01 e 03 . Tem-se por efeito uma movimentação de aproximação e distanciamento entre enunciador e enunciatário, conforme observado nos outros planos de aula que se utilizam dessa mesma estratégia, que estabelece uma modulação que produz a continuidade do simulacro da aula. O uso de "professor" como sujeito da oração e como vocativo acentua a importância do papel temático do enunciatário.

Este plano traz a figurativização do espaço. Na atividade 1, em trechos que já reproduzimos acima, temos: "Na sala de aula o(a) professor(a) deverá explicar aos alunos o que eles irão fazer no Laboratório de Informática. [...] Já no Laboratório de Informática o(a) professor(a) deverá...". Indica-se, assim, o espaço onde se encontra o enunciatário - a sala de aula - e o lugar para onde ele irá se deslocar - o laboratório de informática - para iniciar a próxima atividade. Tem-se uma debreagem espacial enunciva, o não-aqui do enunciador, a partir do qual se organiza o espaço no futuro, tempo da aula. Com exceção do plano 05, que nomeia rapidamente esse espaço tópico, os outros planos anteriores não nomeiam "sala de 
aula", essa localização do destinatário, embora ela seja sempre um local pressuposto, por se tratar de um texto que sempre se propõe a relatar uma situação de aula. Comprova-se essa hipótese observando que, quando a aula, ou parte dela, não se passa na sala de aula, seu espaço é nomeado: o laboratório de informática, a biblioteca da escola, a comunidade escolar, o museu etc. Ainda, pode-se dizer que esse movimento que parte do aqui, a sala de aula, para um não-aqui, o laboratório, é um movimento de abertura de um espaço mais familiar para um menos familiar que, em alguns planos, chega a movimentar-se para fora das salas ("comunidade escolar") e mesmo para a comunidade em geral (plano 05).

Este plano de aula mostra uma maior abertura para o mundo externo à aula, com a indicação de vários endereços da internet para que os alunos assistam a vídeos e consultem informações. Como uso da tecnologia, tem-se o desenvolvimento de atividades como ver vídeo e ouvir música no laboratório de informática e buscar informações por meio de pesquisa em sites com o objetivo de definir o que seja uma boa redação e depois fazer um texto a esse respeito.

Este plano oscila entre um dever mais átono, "oriente", "a leitura poderá..." etc. e um dever mais tônico, com alguns usos de "o professor deverá...". Pode-se dizer, no entanto, que usa, no geral, mais sugestões do que prescrições. Isso pode ser percebido de modo explícito no seguinte: "Em seguida estão algumas sugestões de questionamentos. Você está livre para criar outros, conforme a situação, ou conforme a turma:". Ou seja, pede-se que o plano seja colocado em prática seguindo especificidades do entorno do enunciatário.

Este plano traz uma característica que não aparece em nenhum dos outros planos analisados, que é a presença de um recado para o professor, ao final do item Avaliação.

Professor, espero que dê tudo certo, que você possa desenvolver uma excelente aula e que possa mediar lições de língua crítica e culta.

Com carinho.

Professora Taciana

Aparece um narrador que expressa seu querer, que "dê tudo certo", que o narratário possa realizar a performance para a qual foi competencializado, a de "desenvolver uma excelente aula". Trata-se de uma adição que promove uma relação sensível de afeto entre enunciador e enunciatário. Ainda, ao nomear o papel temático do narrador que, assim como 
o narratário, é um professor, contribui para a construção de um contrato de fidúcia que reforça a identidade entre ambos. Causa, no entanto, algum estranhamento, por inserir um tipo de enunciado que não costuma ser encontrado no plano de aula, que tradicionalmente não lhe pertence, causando uma ruptura no que normalmente constitui esse gênero textual. Essa ruptura provoca, além de um estranhamento, que faz chamar a atenção para si, também um aumento na tonicidade da presença desse enunciador, que se realiza de modo mais próximo e intenso junto a seu enunciatário.

Tem-se, em síntese, no plano de aula 07, a proposição dos objetivos da aula utilizandose verbos no infinitivo, como nos demais planos. Como estratégia discursiva actorial, tem-se uma alternância entre debreagem enunciva e enunciativa, com a utilização de "professor" tanto como vocativo quanto como sujeito da oração. Para o tempo também se alterna o uso das debreagens enunciva e enunciativa, porém as debreagens enunciativas constroem embreagens enunciativas, estabelecendo o futuro como momento de referência da enunciação. Para o espaço, tem-se debreagem enunciva, um não-aqui, figurativizado em "sala de aula" e "laboratório de informática" como espaços pelos quais o sujeito da enunciação irá movimentar-se. Utiliza-se uma estratégia de aproximação entre narrador e narratário que não havia sido observada nos outros planos de aula, ao final, quando aparece um "bilhete" que foge às coerções desse gênero e instaura, marcadamente, a presença da dimensão sensível do sujeito da enunciação.

\subsection{Análise comparativa dos sete planos de aula}

A análise comparativa dos planos de aula que compuseram o corpus desta tese dá algumas respostas para a questão colocada no início deste trabalho, sobre como acontece a organização da transmissão da cultura e a construção do conhecimento no espaço escolar brasileiro no início do século XXI. Assim, a partir das características analisadas, enumeraramse as subseções seguintes, mostrando em cada uma delas o que emergiu dos planos de aula. 


\subsubsection{A seção Objetivos da aula e a seção Avaliação}

Os objetivos e a avaliação representam o início e o final do processo de ensino aprendizagem que o plano de aula contém. Didaticamente, e também do ponto de vista de completude de um processo, eles devem apresentar o que se espera que o aluno aprenda e, ao final, de qual modo verificar se o aluno aprendeu. Ainda, se possível, medir o quanto do que foi proposto foi efetivamente aprendido. Ao chamar a seção de objetivos de "O que o aluno pode aprender com esta aula", o plano de aula disponível no site do Portal do Professor deixa bastante claro do que se trata quando se fala em objetivo da aula. Poderia, nessa mesma linha de raciocínio, ter chamado a seção Avaliação de "Como verificar se o aluno aprendeu o que foi proposto na aula", o que teria dado à avaliação também essa explicitação verbal que traz desejada clareza. Analisa-se a seguir como são enunciados os objetivos de aprendizagem, como eles se classificam de acordo com a Taxonomia de Bloom, como se enuncia a avaliação e, por fim, como se estabelece a relação entre objetivo e aprendizagem nos planos.

Dos sete planos de aula analisados, seis enunciam os objetivos com os verbos no infinitivo, dispostos como itens ou em orações sem sujeito, de modo bastante objetivo, em debreagem enunciva que busca em seu modo máximo o apagamento das marcas da enunciação. O plano 07 apresenta nos objetivos quatro verbos, três dos quais sem objeto, embora não sejam verbos intransitivos. É o plano que os apresenta de modo mais telegráfico (e incompleto). Os planos $01,02,04$ e 06 apresentam-nos no formato verbo mais objeto. 0 plano 03 apresenta os objetivos de modo um pouco mais desenvolvido, com orações que trazem mais especificações sobre os objetos dos verbos de aprendizagem, embora ainda o apresente em forma de itens. O plano 05 traz os objetivos enunciados em orações completas, tendo por sujeito o aluno, "O aluno aprenderá a...", com os verbos no futuro do presente e informações mais detalhadas sobre quais serão os efeitos que se espera daquela aula. Os verbos no infinitivo criam um efeito aspectual durativo, de continuidade (GOMES, 2018), que ajudam a estabelecer entre enunciador e enunciatário um contrato fiduciário que se assenta sobre esse efeito contínuo de duração que tende ao infinito, valor que o enunciador propõe para o aprendizado. Os verbos no futuro do presente, como já dissemos, criam um efeito de 
predição do futuro, estabelecendo entre enunciador e enunciatário um contrato de fidúcia baseado na quase-certeza.

Em relação à verificação de como os objetivos de aprendizagem se classificam segundo a Taxonomia de Bloom, selecionamos os verbos utilizados para sua descrição e os colocamos em uma tabela (a seguir), na qual colorimos as células para identificá-las com os seis níveis da taxonomia, conforme legenda à direita. Tem-se que os planos 02 e 04 trazem objetivos pouco complexos e ficam nos níveis 1 e 2 . Cinco planos, ou seja, a maioria, apresentam objetivos de aprendizagem que atingem o nível 3, de aplicação do conhecimento, que se refere ao "uso de abstrações em situações particulares e concretas" ${ }^{34}$ (BLOOM apud ARMSTRONG, s/d). Três planos indicam objetivos de aprendizagem do grau mais complexo, de avaliação do conhecimento, um engendramento de "julgamento sobre o valor do material e dos métodos para propósitos específicos"35 (ibid.). O plano 05 é o que formula seus objetivos de aprendizagem de modo mais completo, complexo e tônico, seguido pelo plano 07 - não por coincidência, os planos que trazem o conteúdo mais extenso, que solicita grande número de aulas e que o aluno, ao final, produza material autoral.

\begin{tabular}{|c|c|c|c|c|c|}
\hline \multicolumn{6}{|c|}{ LISTA DE OBJETIVOS } \\
\hline plano 1 & visitar & informar-se & $\begin{array}{l}\text { discutir (a } \\
\text { importância) }\end{array}$ & $\begin{array}{l}\text { disseminar (a } \\
\text { informação) }\end{array}$ & \\
\hline plano 2 & compreender & & & & \\
\hline plano 3 & reconhecer & empregar & conhecer & $\begin{array}{l}\text { reconhecer } \\
\text { (diferenças) }\end{array}$ & $\begin{array}{l}\text { saber } \\
\text { (condições) }\end{array}$ \\
\hline plano 4 & conhecer & & & & \\
\hline plano 5 & organizar & analisar & elaborar & perceber & utilizar \\
\hline plano 6 & conhecer & $\begin{array}{l}\text { comparar (as } \\
\text { histórias) }\end{array}$ & $\begin{array}{l}\text { compartilhar } \\
\text { (histórias e } \\
\text { opiniőes) }\end{array}$ & & \\
\hline plano 7 & interpretar & interagir & redigir & criticar & \\
\hline
\end{tabular}

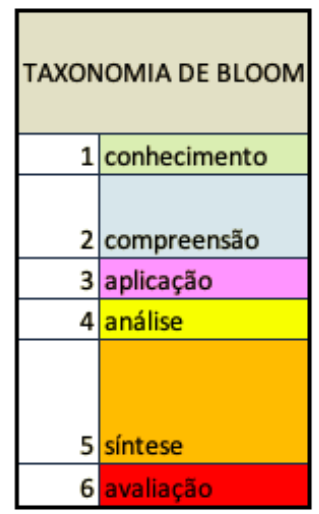

Tabela 2 - os verbos dos objetivos de aprendizagem dos planos de aula analisados.

O item Avaliação apresenta modos de enunciar mais variados do que os da seção Objetivos. Tem-se o uso do futuro como tempo verbal (planos 01, 05 e 07), o uso do

\footnotetext{
34 Tradução nossa. Do original "refers to the 'use of abstractions in particular and concrete situations'."

35 Tradução nossa. Do original "engenders judgments about the value of material and methods for given purposes'."
} 
imperativo (planos 02 e 06), orações introdutórias de finalidade como "Para verificar se os alunos..." nos planos 02 e 03, e os planos 03 e 04 mostram um traço mais deôntico como, por exemplo "Faz-se necessário...", usando, para isso, o tempo verbal presente do indicativo. 0 plano 05 introduz o item Avaliação no tempo futuro do presente, e depois enuncia o que se espera do aluno em forma de itens com verbos no infinitivo, o que não só o diferencia do modo como enunciam os demais planos, mas também, curiosamente, o faz utilizando a forma verbal que os outros planos apresentaram na seção Objetivos, como se estivesse invertendo esses usos. Tem-se, então, nesse plano, o traço de duratividade que aparece no item de avaliação. Em resumo, não se pode dizer que tenha sido encontrado um modo de enunciar que seja comum aos planos de aula analisados para o item avaliação, traço que se relaciona com a crítica que fizemos à avaliação, pouco especificada no tutorial e pouco desenvolvida nos planos, ou seja, a avaliação não apresenta uma regularidade por não ter sido suficientemente tratada - e por não ser suficientemente valorizada no quadro axiológico em que se insere o plano de aula online.

A seguir, apresenta-se tabela que reproduz, na segunda coluna, o que traz o item Avaliação em cada um dos planos de aula, na terceira coluna, o item "O que o aluno pode aprender com esta aula", também reproduzido na íntegra, e, na quarta coluna, comentários de comparação entre eles.

\begin{tabular}{|c|c|c|c|}
\hline PLANO & AVALIAÇÃO & $\begin{array}{c}\text { O QUE O ALUNO PODE APRENDER } \\
\text { COM ESTA AULA } \\
\text { (objetivos) }\end{array}$ & COMENTÁRIOS \\
\hline 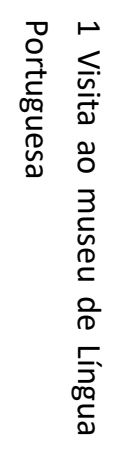 & $\begin{array}{l}\text { A avaliação se dará pela } \\
\text { realização do tutorial, pela } \\
\text { participação do aluno nas } \\
\text { discussões coletivas e, } \\
\text { especialmente, pela produção } \\
\text { de gêneros diversos que } \\
\text { objetivam disseminar } \\
\text { informações sobre o Museu da } \\
\text { Língua Portuguesa. }\end{array}$ & $\begin{array}{l}\text { Visitar e informar-se virtualmente } \\
\text { sobre o Museu da Língua } \\
\text { Portuguesa. } \\
\text { Discutir a importância de se ter um } \\
\text { site sobre o Museu da Língua } \\
\text { Portuguesa. } \\
\text { Disseminar o conhecimento do } \\
\text { Museu na e para a comunidade } \\
\text { escolar. }\end{array}$ & $\begin{array}{l}\text { Os objetivos encontram- } \\
\text { se relacionados à } \\
\text { avaliação, item a item. } \\
\text { No entanto, esta não diz } \\
\text { como verificar se eles } \\
\text { foram atingidos de modo } \\
\text { satisfatório. }\end{array}$ \\
\hline
\end{tabular}




\begin{tabular}{|c|c|c|c|c|}
\hline \multicolumn{2}{|c|}{ PLANO } & AVALIAÇÃO & $\begin{array}{c}\text { O QUE O ALUNO PODE APRENDER } \\
\text { COM ESTA AULA } \\
\text { (objetivos) }\end{array}$ & COMENTÁRIOS \\
\hline 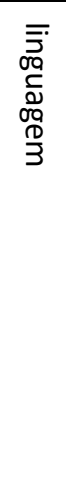 & 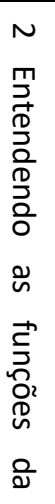 & $\begin{array}{l}\text { PROFESSOR: Para verificar se os } \\
\text { alunos conseguiram internalizar } \\
\text { os conceitos trabalhados, } \\
\text { pesquise vários exemplos de } \\
\text { trechos de textos, entre eles } \\
\text { propagandas, notícias, poemas, } \\
\text { entre outros, e proponha um } \\
\text { exercício de identificação das } \\
\text { funções de linguagem } \\
\text { predominantes nesses trechos. }\end{array}$ & $\begin{array}{lrr}\text { Compreender as funções } & \text { da } \\
\text { linguagem: referencial } & \text { (ou } \\
\text { denotativa), conotativa } & \text { (ou } \\
\text { apelativa), fática, emotiva } & \text { (ou } \\
\text { expressiva), poética } & \text { e } \\
\text { metalinguística. } & & \end{array}$ & $\begin{array}{l}\text { A relação é clara entre os } \\
\text { objetivos e a avaliação e } \\
\text { há uma proposta de que } \\
\text { tipo de exercício de } \\
\text { verificação se deve fazer. }\end{array}$ \\
\hline & 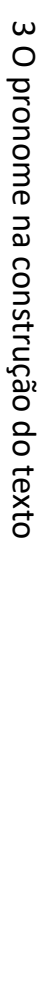 & $\begin{array}{l}\text { Professor, para avaliação de um } \\
\text { tópico tão complexo como o } \\
\text { emprego dos pronomes na } \\
\text { construção do texto, não se deve } \\
\text { levar em conta somente as } \\
\text { regras prescritas pela norma } \\
\text { padrão. Faz-se necessário } \\
\text { apresentar aos alunos diversas } \\
\text { situações de uso que vão } \\
\text { determinar critérios de correção } \\
\text { que se relacionam com a } \\
\text { adequação de uma forma a uma } \\
\text { dada situação. Certamente, o } \\
\text { mais importante é a ampliação } \\
\text { do repertório linguístico do } \\
\text { aluno, apresentando-lhe outros } \\
\text { usos que fogem do seu universo } \\
\text { comunicativo, mas que estão } \\
\text { presentes em alguns discursos. }\end{array}$ & $\begin{array}{l}\text { - reconhecer e empregar pronomes } \\
\text { como elementos coesivos } \\
\text { responsáveis pela reativação do } \\
\text { referente em um texto; } \\
\text { - conhecer as diversas formas de } \\
\text { referência pronominal associadas } \\
\text { às diferentes possibilidades de se } \\
\text { dirigir a interlocutores em } \\
\text { diferentes contextos de } \\
\text { comunicação; } \\
\text { - reconhecer diferenças entre a } \\
\text { norma padrão e o uso não-padrão } \\
\text { de pronomes em textos diversos; } \\
\text { - saber que a escolha pronominal } \\
\text { está condicionada a fatores, tais } \\
\text { como: a natureza do texto, o grau } \\
\text { de formalidade ou informalidade, } \\
\text { os objetivos da interação, a } \\
\text { natureza da modalidade, se oral ou } \\
\text { escrita. }\end{array}$ & $\begin{array}{l}\text { Os objetivos e a } \\
\text { avaliação estão bastante } \\
\text { relacionados, mas ela se } \\
\text { apresenta mais como um } \\
\text { esclarecimento do que } \\
\text { como instruções sobre } \\
\text { como avaliar. }\end{array}$ \\
\hline$\frac{3}{\frac{3}{D}}$ & 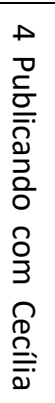 & $\begin{array}{l}\text { É necessário observar se durante } \\
\text { as etapas os alunos reconhecem } \\
\text { as características do gênero, } \\
\text { bem como, promover a } \\
\text { autoavaliação e a avaliação } \\
\text { entre os membros dos grupos } \\
\text { sobre a produção do livro falado } \\
\text { colaborativamente. }\end{array}$ & $\begin{array}{l}\text { Conhecer as características da } \\
\text { poesia: organização textual, rimas, } \\
\text { ritmo; desenvolver habilidades } \\
\text { leitura, interpretação, reflexão e } \\
\text { expressão oral; desenvolver a } \\
\text { atitude de colaboração. }\end{array}$ & $\begin{array}{l}\text { Embora não especifique } \\
\text { como se pode averiguar } \\
\text { que o aluno reconhece as } \\
\text { características do } \\
\text { gênero, a avaliação } \\
\text { relaciona-se bem ao } \\
\text { objetivo da aula. }\end{array}$ \\
\hline
\end{tabular}




\begin{tabular}{|c|c|c|c|}
\hline PLANO & AVALIAÇÃO & $\begin{array}{c}\text { O QUE O ALUNO PODE APRENDER } \\
\text { COM ESTA AULA } \\
\text { (objetivos) }\end{array}$ & COMENTÁRIOS \\
\hline 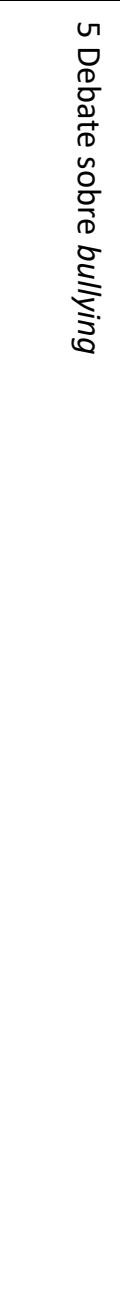 & $\begin{array}{l}\text { (há uma parte de autoavaliação } \\
\text { do aluno que está detalhada nas } \\
\text { atividades) } \\
\text { A avaliação será feita de acordo } \\
\text { com a produção, engajamento } \\
\text { dos alunos no desenvolvimento } \\
\text { e apresentação do resultado de } \\
\text { pesquisa, sempre observando se } \\
\text { o aluno será capaz de: } \\
\text { Demonstrar compreensão de } \\
\text { textos orais, nos gêneros } \\
\text { previstos para as aulas, por meio } \\
\text { de retomada de tópicos dos } \\
\text { textos; } \\
\text { Atribuir sentido a textos orais e } \\
\text { escritos, posicionando-se } \\
\text { criticamente diante deles; } \\
\text { Selecionar procedimentos de } \\
\text { leitura adequados a diferentes } \\
\text { objetivos e interesses (estudo, } \\
\text { formação pessoal, realização da } \\
\text { tarefa) e as características do } \\
\text { gênero e suporte. }\end{array}$ & $\begin{array}{l}\text { O aluno aprenderá a organizar e } \\
\text { analisar os dados de pesquisa, } \\
\text { selecionando artigos } \\
\text { depoimentos que sejam úteis para a } \\
\text { apresentação do trabalho em forma } \\
\text { de debate. Sua pesquisa deverá ser } \\
\text { salva no blog individual criado pelo } \\
\text { aluno para difundir o tema na rede, } \\
\text { para discussão e reflexão, } \\
\text { aprenderá também a elaborar o } \\
\text { discurso oral e escrito, usando } \\
\text { expressões adequadas a um debate } \\
\text { deliberativo, apresentando } \\
\text { argumentos que embasem a } \\
\text { posição tomada e com sugestões } \\
\text { coerentes para serem colocadas em } \\
\text { funcionamento dentro } \\
\text { comunidade escolar, tão logo } \\
\text { findem as atividades em sala sobre } \\
\text { o assunto. Aprenderá a perceber e } \\
\text { utilizar a concordância verbal e } \\
\text { nominal para clareza do material } \\
\text { produzido. E também se sentirão } \\
\text { valorizados, elevando a auto estima } \\
\text { ao repassar as informações à toda } \\
\text { escola. }\end{array}$ & $\begin{array}{l}\text { Trata-se do plano de aula } \\
\text { que, além de expor os } \\
\text { objetivos de modo mais } \\
\text { detalhado e completo, } \\
\text { também melhor } \\
\text { relaciona objetivos e } \\
\text { avaliação, pois os } \\
\text { mantém sobre os } \\
\text { mesmos pontos. No } \\
\text { entanto, diz o que avaliar } \\
\text { nos alunos, mas não } \\
\text { como fazê-lo. }\end{array}$ \\
\hline 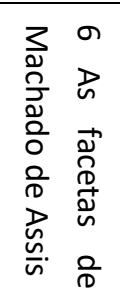 & $\begin{array}{l}\text { Verifique o crescimento do } \\
\text { interesse dos alunos de acordo } \\
\text { com os saraus realizados. } \\
\text { Identifique se os alunos estão } \\
\text { procurando conhecer outras } \\
\text { obras do autor. }\end{array}$ & $\begin{array}{l}\text { Conhecer vários contos de } \\
\text { Machado de Assis; Comparar as } \\
\text { histórias e seus entrelaces. } \\
\text { Compartilhar histórias e opiniões } \\
\text { sobre a obra do autor estudado. }\end{array}$ & $\begin{array}{l}\text { A avaliação se relaciona } \\
\text { pouco com os objetivos e } \\
\text { não diz como verificar ou } \\
\text { identificar o que se } \\
\text { propõe. }\end{array}$ \\
\hline
\end{tabular}




\begin{tabular}{|c|c|c|c|}
\hline PLANO & AVALIAÇÃO & $\begin{array}{c}\text { O QUE O ALUNO PODE APRENDER } \\
\text { COM ESTA AULA } \\
\text { (objetivos) }\end{array}$ & COMENTÁRIOS \\
\hline 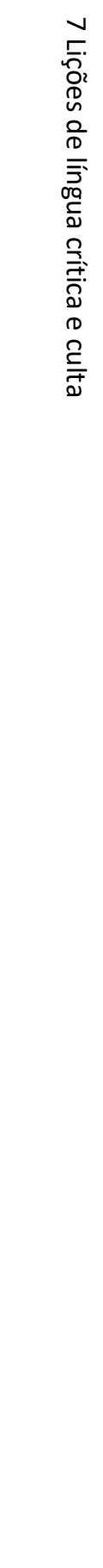 & 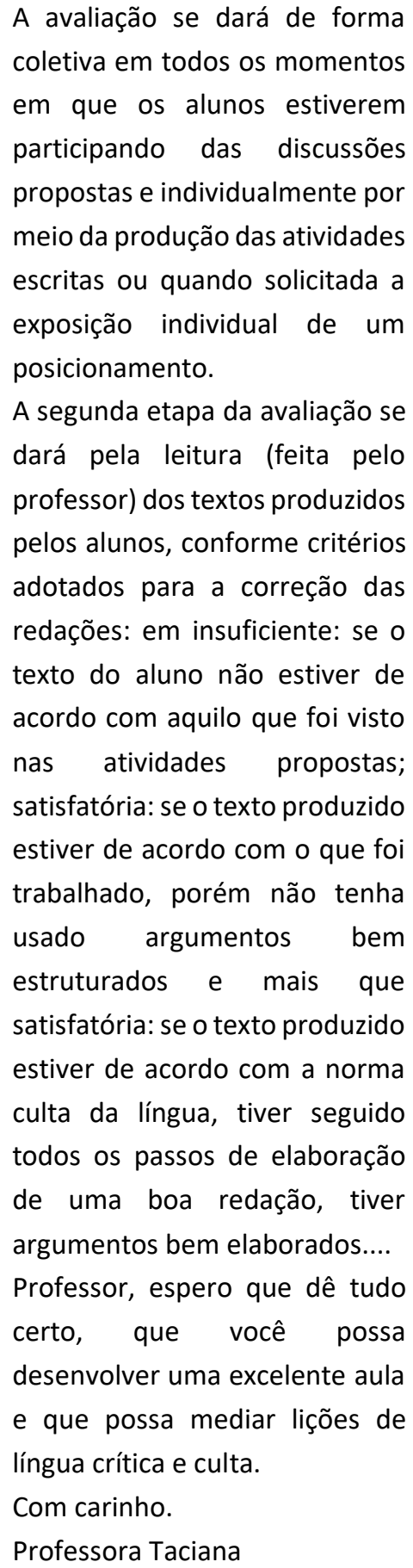 & $\begin{array}{l}\text { Interpretar diferentes tipos de } \\
\text { textos; } \\
\text { Interagir e redigir; } \\
\text { Criticar. }\end{array}$ & $\begin{array}{l}\text { Embora não diga } \\
\text { especificamente como } \\
\text { avaliar a participação do } \\
\text { aluno no coletivo, a } \\
\text { avaliação apresenta-se } \\
\text { bem relacionada aos } \\
\text { objetivos propostos e é } \\
\text { clara quanto à avaliação } \\
\text { do texto produzido pelo } \\
\text { aluno. }\end{array}$ \\
\hline
\end{tabular}

Tabela 3 - comparação entre objetivos e avaliação nos planos de aula.

Fonte: elaboração própria a partir dos planos de aula que integram o corpus. 
Em relação à comparação entre a avaliação e os objetivos propostos, pode-se verificar que, nos planos 02,04 e 07 , os objetivos colocados são muito generalistas e, por isso, embora tenhamos apontado que há uma relação entre objetivos e avaliação, resta evidente que essa relação é fácil de ser estabelecida dada a amplitude dos objetivos. No caso dos planos $02 \mathrm{e}$ 04, trata-se de objetivos muito simples e átonos. No caso do plano de aula 07, a razão para isso é que, como os verbos são enunciados sem objeto, podem ser aplicados a um grande número deles. Esse mesmo plano 07 traz um maior detalhamento sobre como avaliar o texto do aluno, propondo aplicar-lhe uma classificação de insuficiente, satisfatório, mais que satisfatório, o que ajuda o enunciatário do plano a estabelecer critérios de avaliação. No plano 05, esses critérios são apresentados ao próprio aluno para que ele faça uma autoavaliação.

Como se pôde perceber na tabela, de modo geral, a avaliação é pouco desenvolvida nos planos e em quase todos os casos não há indicações de "como" fazer, apenas sobre "o que" deveria ser verificado. Trata-se de um ponto vulnerável dos planos de aula analisados, característica que acreditamos que se estenda para o planejamento de aulas em geral, dado que também não foi objeto de muita atenção no tutorial que ensinava a elaborar uma aula que poderia ser publicada no Portal (analisado no capítulo 1). Sabemos que há áreas dos estudos de Educação escolar e Pedagogia que têm buscado desenvolver trabalhos nesse sentido e, dado que o corpus desta tese já tem cerca de dez anos, não podemos afirmar que continua sendo uma área problemática. Mas há fortes indícios de que, por ser uma área delicada e merecedora de atenção, tal situação não se resolva tão rápida ou facilmente. Ainda, chama nossa atenção o fato de que em três dos sete planos o enunciatário seja convocado por meio de um vocativo, "Professor", no espaço em que se enuncia a avaliação. O vocativo mostra um enunciador que produz o seu enunciado em direção a um enunciatário do qual se aproxima não apenas com o uso da debreagem enunciativa, mas também interpelando-o por seu papel temático. Provoca-se um efeito de aproximação horizontal, de familiaridade, e retoma-se um efeito de sentido de momento de troca de informações mais importantes, como apontamos no plano de aula 01 quando se dirige ao professor dessa mesma maneira. No entanto, de modo semelhante ao que foi visto no plano 01, cria-se assim também um efeito de que a avaliação se aproxime mais de uma "dica", quando, na verdade, se trata de uma parte importante do processo que precisa ser tratada com metodologia 
adequada. Reforça-se essa impressão de que a avaliação não seja tratada com a sistematização e formalidade de que necessita ao se verificar que, no plano de aula 07, é deixado um "bilhetinho" para o professor-enunciatário por parte do professor-enunciador, desejando que "dê tudo certo" - um traço de informalidade que apela ao sensível em um lugar de relações que deveriam estar na esfera do inteligível.

Quando os objetivos se apresentam pouco relacionados com a avaliação, tem-se, no geral, um plano de aula que não ata suas pontas, estas que poderiam ser nomeadas como um ponto de partida, vislumbrando "onde se quer chegar" (objetivos), e um de chegada "como verificar se se chegou lá" (avaliação). Não apenas desejável, mas também recomendado pelo MEC, é que se tenha um plano de aula que tenha objetivos significativos, tônicos e relacionados de modo claro à avaliação (e às atividades, de que não tratamos neste item), como está solicitado no tutorial de criação de aula do Portal do Professor (analisado no item 1.4.2). Cabe à avaliação dar acabamento ao processo de ensino-aprendizagem em aula, atestando se o destinatário está de posse da competência que se lhe foi endereçada. A avaliação é o meio pelo qual o professor poderá sancionar o aluno em relação ao aprendizado esperado e, também, o modo como poderá ser sancionado, por si mesmo e por outros sujeitos, para verificar se o plano de aula resultou em uma "boa aula", conforme desejado.

Apresenta-se, portanto, como uma característica dos planos de aula online a enunciação de objetivos de aprendizagem de modo objetivo, sucinto, com aspecto temporal contínuo e durativo; relação existente, porém tendendo a átona, entre objetivos e avaliação e uso de verbos para enunciar os objetivos que tendem a ser classificados como medianos de acordo com a Taxonomia de Bloom. Essa, em nosso entendimento, constitui uma boa metodologia cujo uso poderia ser mais disseminado entre os professores e utilizada como forma de melhorar o processo de ensino-aprendizagem, combinada a uma maior atenção no estabelecimento de verificação na fase final do processo, a avaliação. Não se apresenta regularidade na escolha das estratégias discursivas para o modo de enunciar a seção Avaliação, o que faz acentuar nossa percepção de que ela seja uma seção com a qual o enunciador tem pouca familiaridade. Por isso, é possível atribuir ao plano de aula online um traço de inacabamento disfórico, de tendência à incompletude do processo que ele propõe. 


\subsubsection{Estratégia discursiva actancial}

A análise das estratégias discursivas actanciais nos revela que todos os planos de aula analisados trazem, em sua integralidade (planos 02 e 06), ou em algum momento (todos os outros), o uso da debreagem enunciativa, seja enunciando-se como um "eu" (plano 05), seja dirigindo-se a seu enunciatário como um "tu" (todos os demais) que instala, sem explicitar, um "eu". Nos planos 01, 03 e 07, há predomínio de debreagem enunciva. Neles se busca apagar um pouco mais as marcas da enunciação no enunciado, o que resulta numa estratégia discursiva que produz o efeito de o texto parecer mais objetivo. O plano 04 se utiliza pouco da debreagem enunciativa (apenas duas ocorrências de verbos no imperativo) e, ainda, busca construir uma objetividade mais tônica ao apagar marcas da enunciação ao longo do texto, recorrendo ao uso de verbos com sujeito indeterminado (por exemplo: "Pode-se propor que façam..."). No entanto, a enunciatividade está lá, ainda que atenuada. O imperativo, embora faça parecer menor subjetividade porque decorrente de comando ou instrução - dada a tendência de pensar em subjetividade como geradora de efeito de proximidade - não deixa de ser da ordem das relações que se colocam entre "eu" e "tu". Ainda, tendemos a pensar que, ao nos lembrar que o plano de aula online é chamado no Portal de "Sugestão de aula" e que entre enunciador e enunciatário se estabelece uma relação de identidade (como veremos a seguir), resta atenuado o lado de "comando impessoal" do uso do imperativo que se apresenta no plano. Pode-se, então, dizer, com base na presença constante de debreagens enunciativas nos planos, que, mesmo que o enunciador tente colocar-se objetivamente para o enunciatário, há uma recorrência à subjetividade, com a produção de um efeito de proximidade, mesmo quando construída de modo átono, e que os verbos no imperativo que nele se encontram tendem a mais sugerir do que a ordenar. Assim, pensa-se que a estratégia discursiva dos planos de aula online se dá em graus de aproximação subjetiva e sensorial: há planos em que o enunciador se constrói como mais próximo do enunciatário; em outros, menos.

A alternância entre o uso de debreagens actoriais enuncivas e enunciativas faz criar um movimento de oscilação na relação entre enunciador e enunciatário. Enquanto o uso da estratégia enunciva traz objetividade, produzindo um efeito de distanciamento desejável para 
as relações que se dão na esfera pública, a construção da subjetividade pelo uso das estratégias enunciativas personaliza a relação e faz aproximar os sujeitos. Tal movimento oscilatório tem por efeito a continuidade da relação entre enunciador e enunciatário (cf. Tatit, 2010: 20-43).

Recorremos a Fontanille e Zilberberg (2001) para pensarmos na alternância percebida no uso das estratégias actoriais discursivas pelo sujeito da enunciação no plano de aula. Partese do pressuposto de que a existência semiótica se apresenta como um objeto de saber para o sujeito cognitivo, e que essa relação sujeito e objeto se assenta sobre uma base perceptiva na qual se encontra a apreensão de toda significação (ibid.: 124). Para se falar em presença, pensa-se sempre no par presença e ausência, um termo complexo cujos termos articulam-se no espaço tensivo por combinações moduladas, ou seja, por combinações de seus gradientes. A partir desse conceito, nota-se que, nos planos de aula online, o enunciador modaliza sua presença para o enunciatário, o que se observa na variação que utiliza no modo de projetarse no enunciado por meio das debreagens empregadas, como mostramos. Ao mostrar-se próximo, porém distante, ou distante, embora próximo; objetivo, ainda que subjetivo, ou subjetivo, porém objetivo; na esfera pública, porém tratado como se estivesse na esfera privada, e vice-versa, o enunciador do plano de aula online mostra operar no regime da concessividade, construindo relações do tipo [e...e]: ele se coloca próximo e distante; objetivo e subjetivo; na esfera pública e na privada, ao mesmo tempo. Há um jogo de surpresa - concebendo-se surpresa como uma concessão gradual, um pequeno acontecimento ${ }^{36}$ - colocado em cena quando se colocam esses contrários, inesperados, que estabelecerão esse movimento modulatório, em um discurso que é tão programado, que opera de modo tão adequado ao exercício ${ }^{37}$. A modalização, assim, tonifica a relação, ainda que, em se tratando do plano de aula, também a tonificação não seja tão acentuada, situada mais próxima da esfera da "justa medida" (como veremos a seguir).

Às estratégias discursivas que tendem a efeito de proximidade, adiciona-se a de tematização do narratário, cujo revestimento figurativo é alternado entre o papel temático

\footnotetext{
${ }^{36}$ Sobre as concessões graduais, Coutinho e Mancini (2020).

${ }^{37}$ Concebendo que o exercício está para o pervir (esperado) assim como o acontecimento, ou, no nosso caso, a surpresa, está para o sobrevir (inesperado).
} 
de "professor" e o de "aluno", operando-se assim a referencialização da cena enunciativa por meio da concretização de seus atores. O lexema "professor" aparece nos planos como vocativo (planos 01, 02, 03 e 07) ou como sujeito da ação (planos 01, 03, 04,06 e 07). Podese notar que ele está presente em quase todos os planos de aula e o único que não o usa, nem como vocativo, nem como sujeito da ação, é o plano 05, que constrói a aproximação entre destinador e destinatário com a inserção da dimensão sensível no plano, como visto em sua análise. O efeito da constante tematização do destinatário reforça sua identidade e a identificação de ambos, enunciador e enunciatário, como pertencentes à mesma esfera discursiva. O destinador do plano de aula online também é construído marcadamente como pertencente à esfera discursiva escolar, como um professor ou como um ator da esfera escolar educacional, que se coloca como um sujeito do saber dar aulas. Em cada plano de aula se institui um narrador, que recebe um investimento semântico de identificação ancorado no mundo, personificado, já no cabeçalho do plano. Tem-se aí nome completo, cidade e instituição às quais pertence o destinador e um espaço para foto que, no nosso corpus, estava preenchido em apenas dois dos sete planos, mas que observamos estar preenchida em outros planos do site. Há, portanto, uma personificação desse ator da narração, com dados que produzem o efeito de uma "pessoa de carne e osso" como autor daquele plano de aula. Isso cria um efeito de identidade entre enunciador e enunciatário, ambos professores que se situam em um lugar comum aos dois. Essa identificação entre eles é eufórica e os aproxima, intensificada pelo tom coloquial que se encontra em muitos planos de aula - bilhetinho no final (plano 07), interpelações ao "professor" com dicas para tornar a aula mais interessante (plano 01) etc. Além disso, a aproximação se respalda no uso de debreagem enunciativa em todos os planos, mesmo naqueles em que essa estratégia discursiva não aparece como predominante, como mostramos. Assim, constata-se que o direcionamento horizontal do percurso de comunicação construído pelo narrador dos planos de aula favorece a persuasão do destinatário por se colocar com ele em uma relação de semelhança, em vez de uma relação hierarquizada, vertical, que teria sido construída caso os planos de aula se identificassem como tendo sido feitos pelo Portal do Professor. Tem-se, portanto, a construção de uma identidade dos papéis sociais dentro da escola. 
O professor, lexicalizado em posição de vocativo, aparece como convocado pelo enunciador a destacar pontos fortes e aproveitar oportunidades, no plano 01; é convocado a fazer (explicar, pedir, verificar), no plano 02; é lembrado daquilo que se coloca como importante, no plano 3; é relembrado dos objetivos das atividades e de que poderá interferir nas apresentações dos alunos, no plano 07, cujo enunciador também espera que ele "possa desenvolver uma excelente aula". Como sujeito da ação, o professor acessa a web, abre uma roda de discussão, pede aos alunos, organiza os alunos e também propõe uma visita presencial ao museu no plano 01; deve reproduzir as tirinhas, deve levar os alunos ao laboratório, deve fazer a correção dos exercícios e deve reproduzir o conto no plano 03; lê para os alunos e deve provocar a revisão do material no plano 04; necessita ter sido seduzido antes de seduzir os alunos, no plano 6; questiona os alunos e deve explicar e orientá-los no plano 07. Em resumo, enquanto vocativo, o professor é chamado para lembrar ou relembrar pontos que são importantes, mas, quase sempre (exceção ao plano 2), não essenciais para a aula. Enquanto sujeito da ação, é alguém que tem um fazer ou, em especial nos planos 3 e 7 , um dever fazer referente às atividades da aula. O percurso temático que se desdobra a partir do lexema "professor" é construído como um sujeito que faz [a aula acontecer].

Importa também observar, nos planos de aula, como se constrói a imagem do aluno, destinatário da aula. A palavra "aluno" é onipresente nos planos, seja como sujeito da ação (alunos divulgam, acessam, conectam-se...), seja como objetos da ação do professor (são organizados em roda, levados à reflexão etc.). Eles estão na centralidade do processo da aula, conforme é solicitado no tutorial de criação de aula do Portal (analisado no capítulo 1). Há dois pontos que se mostram relevantes para essa análise: as debreagens internas e os revestimentos temáticos e figurativos. Com exceção dos planos 04 e 06 , todos os outros apresentam debreagens de segundo grau, nas quais se estabelece um interlocutor revestido do papel temático do professor, situado no tempo e espaço da aula, que irá interpelar um interlocutário revestido do papel temático de aluno. Elas são todas enunciativas, predominantemente com a proposição de perguntas (planos 01, 02, 03, 05 e 07), na maior parte das vezes dirigindo-se ao aluno como "você" (em 03, 05 e 07). Para demarcar onde se iniciam essas debreagens de segundo grau e como elas se constroem, os planos utilizam-se de algumas estratégias que mostramos a seguir. 
No plano 01, propõe-se um Tutorial para ser respondido pelos alunos, marcado no plano da expressão por estar dentro de uma moldura aplicada ao parágrafo e em cujo cabeçalho se lê "TUTORIAL" (ver figura 9, neste mesmo capítulo). As perguntas são diretas e visam a respostas mais pontuais, como, por exemplo: "O que o link Programação oferece aos visitantes?". No plano 02, coloca-se a pergunta para o aluno, e em seguida a instrução, para o professor, para que ela seja endereçada aos alunos: "Como ele [o texto] o faz [influencia o leitor]? Coloque esta questão para seus alunos."; as questões também pedem respostas mais curtas e diretas - "Por que temos o hábito de atender ao telefone dizendo 'alô'?”. O plano 03 informa que a atividade deverá ser entregue aos alunos para que realizem as atividades propostas e, na sequência, apresenta a tirinha e as questões a seu respeito que devem ser diretamente endereçadas aos alunos, conforme mostra a figura 13 , a seguir ${ }^{38}$.

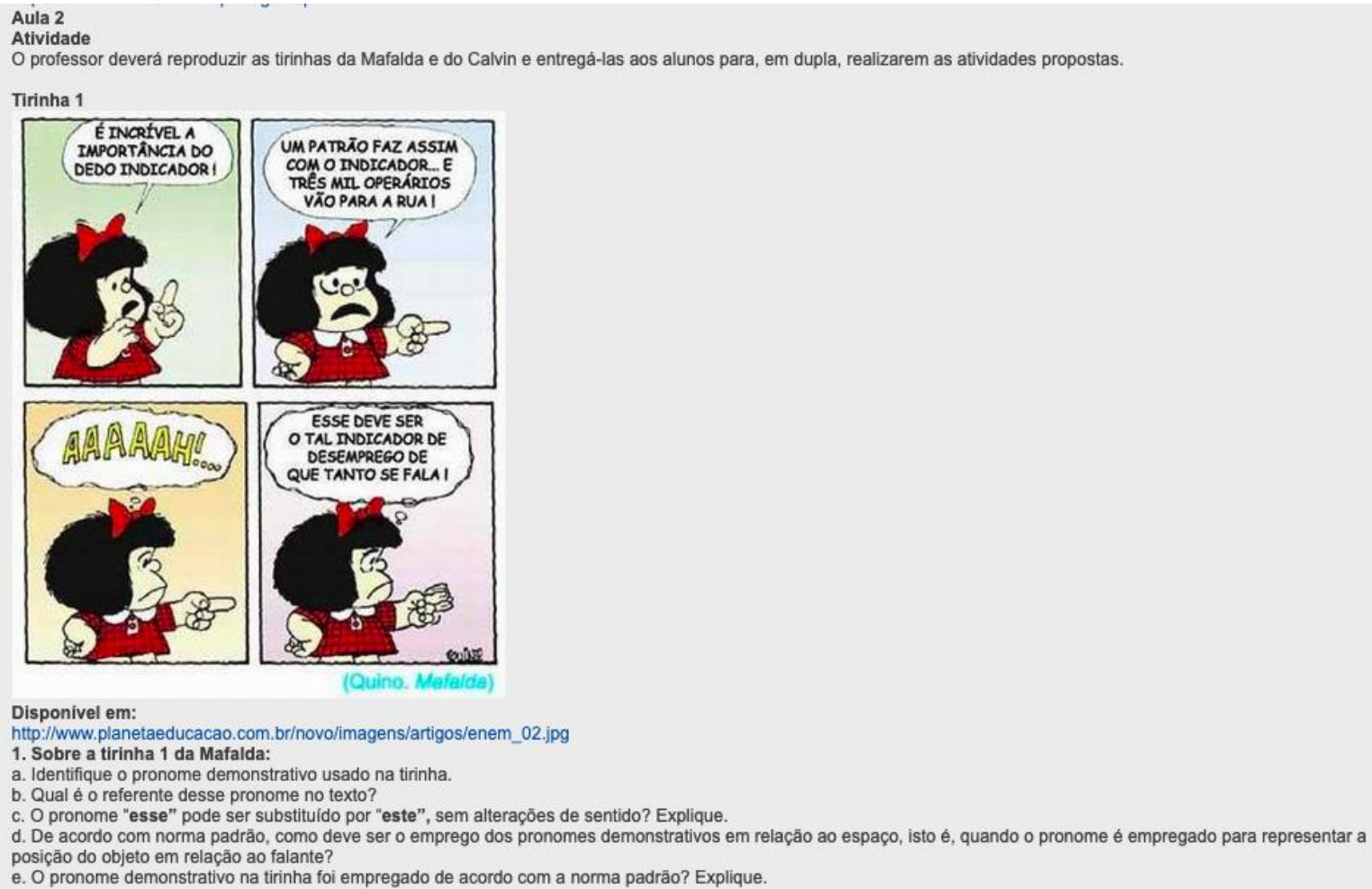

Disponivel em:
http://www.planetaeducacao.com.br/novo/imagens/artigos/enem_02.jpg

(Quino. Mafalde)

1. Sobre a tirinetaeducacao.com.

1. Identifique o pronome demonstrativo usado na tirinha.
a. Q

b. Qual e o referente desse pronome no texto?

c. Qual e o reforente desse pronome no

d. De acordo com norma padrão, como deve ser o emprego dos pronomes demonstrativos em relação ao espaço, isto é, quando o pronome é empregado para representar a pão ao falante?

e. O pronome demonstrativo na tirinha foi empregado de acordo com a norma padrão? Explique.

Figura 13 - Exemplo de debreagem interna, plano de aula 3.

O plano 05, para introduzir as falas aos alunos, da primeira vez, enuncia "(fala destinada ao aluno)"; depois, vai pontuando ao longo das atividades "Instruções para os alunos", "Texto para os alunos". Há um momento em que ele não deixa explícito que a fala

\footnotetext{
${ }^{38}$ As questões que constam nessa imagem estão reproduzidas no item de análise individual do plano de aula 03.
} 
que estava sendo destinada ao professor passa a ser ao aluno, mas é possível identificar essa alternância do destinatário do discurso por meio de seu conteúdo e da linguagem empregada. Quando se dirige aos alunos, é sempre enunciativamente, utilizando "você" e "nós", e com o registro de linguagem marcadamente diferente, mais informal do que utiliza para falar com o professor. Constrói-se um diálogo com esse aluno projetado no texto:

Texto para os alunos:

Estão sabendo agora do que se trata? Então, farão o texto argumentativo sobre o assunto. Bateu a dúvida de como produzir um texto argumentativo? vamos rever em sala de aula como organizar o texto argumentativo. Agora que estão bem espertos com o que é o bullying, vocês irão assistir alguns slides sobre isso, aprofundando-se no assunto para informar aos pequenos de nossa escola como agir ou reagir quando perceber o bullying. (plano de aula 05)

O plano 07 avisa que trará uma sequência de perguntas que podem ser dirigidas diretamente aos alunos, reproduzidas em negrito, a seguir. Apresenta-as como sugestões, ao contrário dos planos anteriores, que as endereçaram mais como prescrição:

Na sequência o professor fará questionamentos aos alunos para que reflitam sobre o que leram e o que assistiram. Em seguida estão algumas sugestões de questionamentos. Você [professor] está livre para criar outros, conforme a situação, ou conforme a turma: As imagens condizem com a letra da música? A letra da música possui conteúdo real ou imaginário? A linguagem presente no texto é uma linguagem figurada? Por quê? Quem são as pessoas que realizam o trabalho de construção? Por que, mesmo conhecendo a obra, tendo ajudado a construí-la essas pessoas ficam do lado de fora e são vistas como ladrões, pelos cidadãos comuns, ao admirála? (plano de aula 07, negrito nosso)

Observar como se marca o início dessas debreagens internas nos mostra como o enunciador faz a transição de direcionamento da sua fala, do destinatário do plano de aula, o professor, para o destinatário da aula, o aluno. Têm-se demarcações bem delimitadas, o que traz clareza para que o enunciatário do plano de aula se perceba competencializado para a construção de seu objeto valor "boa aula", pois ele é capaz de saber o que terá a dizer em momentos específicos durante sua perfórmance.

Quanto ao tipo de proposta que é colocada para o aluno nessas debreagens de segundo grau, podemos observar que os planos 05 e 07 se dirigem a um enunciatário-aluno 
que mostra maior competência para refletir sobre os problemas e produzir conteúdo a partir deles (debate e disseminação de informações para a escola no 05, redação sobre exclusão social no 07). Esses dois são os planos de aula mais longos e os que apresentam as atividades a serem desenvolvidas pelos alunos também com essa mesma característica de duratividade mais extensa. Os outros planos $(01,02$ e 03) se dirigem a um aluno que irá cumprir atividades mais pontuais, de responder a questões propostas. O contraste entre os tipos de projeção do aluno destinatário dessa debreagem mostra que os planos, tomados como totalidade, não concebem com uniformidade um enunciatário-aluno a quem se dirigem.

O lexema "aluno", no singular e no plural, é onipresente nos planos de aula, com muitas ocorrências (mais de dez vezes nos planos 01, 02, 05 e 07, sendo que no plano 07 são 17 ocorrências de uso pelo enunciador do plano de aula ${ }^{39}$ ). Ele aparece cerca de duas vezes mais como complemento verbal ou nominal do que como sujeito da ação. Como sujeito da ação, alunos enviam arquivos (plano 01), são convidados a gravar um livro (plano 04), leem e criam blogs (plano 05), expõem o que aprenderam (plano 07) etc.; são, portanto, sujeitos do fazer da construção da aula. Como objeto do verbo, "aluno" é sempre alvo da ação do professor: entregar as tirinhas aos alunos (plano 03), questionar ou perguntar aos alunos (planos 02 e 07), pedir aos alunos (planos 01 e 02), seduzir os alunos (plano 06), ler para os alunos (plano 04)... Como complemento nominal, há a participação do aluno (plano 01), a dúvida dos alunos (plano 03), o livro falado dos alunos (plano 04), as instruções para os alunos, o grupo de alunos, o texto para os alunos (plano 05), as sugestões dos alunos (plano 07). Depreende-se dessa observação da sintaxe de construção dos enunciados que a figura do aluno constitui o pivô central do plano de aula, que gira em torno dele, e que o fazer orbital da aula em torno dessa figura cabe ao professor. Essa configuração era esperada, dadas as características do plano de aula de espelhar o fazer do professor na sala de aula contemporânea, para a qual se demanda centralidade no aluno (PCN e correntes pedagógicas diversas, que já aparecem no tutorial de como fazer uma aula no site Portal do Professor).

Em resumo, a estratégia discursiva actancial do plano de aula online é predominantemente enunciativa, mostrando um enunciador que ora se aproxima, ora se

\footnotetext{
39 Não foram contabilizados os usos de "aluno" que estão nos nomes ou descrições dos campos a serem preenchidos, porque não foram produzidos pelo narrador do plano de aula.
} 
afasta de seu enunciatário, que modula sua presença e, desse modo, cria um discurso que opera em regime concessivo, em que as relações [e...e] dão continuidade a essa relação entre os actantes do enunciado pelos efeitos que criam: próximo e distante, relações objetivas e subjetivas. Essas relações se colocam no campo público, um texto escolar publicado online, mas, também, ao mesmo tempo, operam no privado: de professor para professor, "com carinho". Essa concessividade causa pequenas surpresas que contribuem para a manutenção da relação entre enunciador e enunciatário. Ainda, ao utilizar-se de debreagens internas para fazer de seu enunciatário o aluno, destinatário da aula, o narrador do plano de aula online reforça a construção dele como um simulacro da aula e como construtor da competência do professor, seu destinatário, para esse saberfazer. Quanto ao aluno como destinatário da aula, constatou-se que não há uma uniformidade em sua concepção, com propostas ora mais elaboradas, ora mais simples, endereçadas a ele. Como tematização e figurativização dos atores, tem-se o professor como um sujeito do fazer e o aluno colocado como eixo central da aula e desse fazer do professor.

\subsubsection{Estratégia discursiva temporal}

O uso da debreagem temporal constitui uma das características mais peculiares do plano de aula online, destacando-o como gênero textual que utiliza a debreagem enunciva em que o momento de referência é instaurado não concomitante ao da enunciação, posteriormente, no futuro. A instalação do momento de referência no futuro é um procedimento bem menos utilizado nos discursos do que o de estabelecimento do momento de referência no passado (FIORIN, 2002). Ocorre, em geral, em horóscopos, previsão do tempo, profecias em geral ou em narrativas apocalípticas, nas quais se constrói um efeito de alguém que enuncia sabendo dos acontecimentos que virão. Fiorin (idem: 154) também traz que o valor de verdade no futuro não pode ser determinado no momento da enunciação e que só se faz asserções no futuro se a elas estiver acoplado um valor modal, que depende da avaliação que o enunciador faz da necessidade, probabilidade, possibilidade ou impossibilidade da ocorrência de um dado estado de coisas. 
Por exemplo, no livro do Apocalipse, tem-se um anjo que diz "Não tenhas medo do que irás sofrer, o diabo irá lançar alguns de vós na prisão, para serdes provados, e tereis um sofrimento de dez dias." (Ap. 2: 10, negritos nossos). Eis um enunciador que, por sua condição angelical e sobrehumana, se mostra possuidor de um saber que lhe permite narrar o pervir com a certeza do acontecimento e do desenrolar dos fatos a partir desse momento futuro. Por isso, utiliza-se primeiramente do futuro do presente, "irás sofrer" e "o diabo irá lançar" e, em seguida, mostra a instauração da narrativa em um momento de referência no futuro, enunciando o que acontecerá a partir daquele momento: "tereis um sofrimento de dez dias". O plano de aula online constrói narrativas com estratégias temporais semelhantes a essa.

Dos sete planos de aula analisados, dois, os planos 02 e 06 , se utilizam de debreagem temporal enunciativa, com verbos no imperativo, instaurando o momento de referência concomitante ao da enunciação. Outros três planos, 01, 03 e 05, empregam debreagem temporal enunciva, usando o futuro do presente como momento de referência não concomitante. O plano 07 , embora se expresse em outros tempos verbais que não apenas o futuro do presente, também usa como estratégia o posicionamento do "agora" da enunciação no futuro e, por fim, o plano 04, que, como mostrado, usa o presente como uma embreagem do futuro do presente, não concomitante. Pode-se, portanto, colocar como característica do plano de aula a construção de estratégia discursiva temporal não concomitante e posterior ao momento da enunciação, instaurando a debreagem enunciva no futuro. O uso dessa estratégia traz o efeito de um enunciador que se instaura nesse tempo futuro e passa a narrar a partir de então. Desse modo, cria-se no plano de aula o efeito de um simulacro da aula e de um enunciador que, como o anjo do Apocalipse, é conhecedor dos fatos que acontecerão, não por ser sobrehumano, mas por já ter passado por aquela experiência e, por isso, estar revestido de um saber fazer.

Os planos que empregam debreagens temporais enunciativas usando verbos no imperativo mantêm uma uniformidade do uso de debreagens actoriais também enunciativas. Eles mostram uma escolha de estratégia discursiva do sujeito da enunciação que é condizente com o que se encontra em manuais de instrução e outros discursos programadores de construção de um objeto valor. O uso do presente como tempo enunciado produz, para além do efeito de subjetividade que lhe é inerente, neste caso, também o efeito de uma certa 
atemporalidade, mais preocupada com o conteúdo da instrução e seu sequenciamento do que com a alocação do discurso no tempo.

Os planos que utilizam o futuro como momento de referência, por outro lado, não o usam uniforme e exclusivamente, mas o alternam com ocorrências do modo imperativo do sistema enunciativo. Essa alternância nas estratégias discursivas temporais, na pequena surpresa que a concessividade de seu uso produz, cria a modulação da continuidade do discurso que produz um efeito de maior certeza em relação à realização desse fato no futuro, contrapondo-se à incerteza, que se tem normalmente como efeito desse tempo verbal.

Esses mesmos planos que apresentam a alternância entre o sistema enuncivo e o enunciativo nas estratégias temporais também o fazem em relação às estratégias discursivas actoriais. Assim, tem-se que operam no regime concessivo não apenas em relação à inserção da pessoa no discurso, mas também em relação ao tempo. Pela combinação das estratégias discursivas actoriais e temporais, tem-se um enunciador que cria um movimento modulatório da enunciação no espaço tensivo, operando na concessividade. Para pessoa, obtinha-se os efeitos de subjetividade e objetividade, proximidade e distância, público e privado. Como resultado da combinação dessa característica nas categorias de pessoa e tempo, tem-se a criação de um discurso que parece estar situado, concomitantemente, na incerteza trazida pelo uso do tempo verbal futuro e na quase-certeza que decorre da estratégia descrita. Daí podermos arriscar dizer que a modalidade que acompanha esse enunciado é a da probabilidade tônica da ocorrência do narrado e que essas construções discursivas fazem intensificar o efeito de predição da aula criado pelo sujeito da enunciação do plano de aula online.

\subsubsection{Estratégia discursiva espacial}

Nossa hipótese para a estratégia discursiva espacial construída pelo sujeito da enunciação no plano de aula online é de que, principalmente nos planos em que a debreagem temporal é instaurada no momento de referência não concomitante à enunciação, no futuro, o espaço da enunciação instaurado esteja fora da cena enunciativa e constitua, portanto, uma 
debreagem espacial enunciva. Essa hipótese se constitui também ao se pensar que as categorias de tempo e espaço projetados no enunciado apresentam certa uniformidade entre $\mathrm{si}^{40}$ e que, desse modo, o uso do futuro como momento de referência temporal não concomitante à enunciação demandaria um acolá como referência espacial, ambos enuncivos. No entanto, a figurativização do espaço tópico como "escola", por meio dos revestimentos figurativos que Ihe são dados pelo enunciador, produz um efeito, para o enunciatário, de referenciação do espaço para uma sala de aula, e ele se percebe na cena discursiva narrada. Cria-se, portanto, um efeito de presentificação desse espaço da aula que se torna o aqui da cena enunciva para a qual são projetados enunciador e enunciatário. Constrói-se, de modo análogo ao que seria um "presente do momento de referência futuro", um "aqui" desse espaço de referência. Essa construção espacial acentua o efeito de predição da aula e faz com que enunciador e enunciatário "se transportem" para a "cena enunciativa" da aula que acontecerá.

Como nos traz Fiorin (2002), os espaços linguísticos são especificados pelos espaços tópicos e pela posição do narrador-observador que aí se encontra. Sendo organizados a partir da posição desse enunciador, os espaços propostos precisam ser aceitos pelo enunciatário. Tem-se, nos planos de aula online, um enunciador que não especifica onde é o seu aqui, trazendo o efeito de que ele enuncia a partir de algum outro lugar. Esse não-aqui, no entanto, poderia ser enunciativo, um lá, cuja referência continua sendo o enunciador na cena enunciativa, ou um acolá, enuncivo, cuja referência está fora da cena enunciativa. Antes de apontarmos as indicações de espaços tópicos, compreendidos como semantizações do espaço que servem como referenciadores que ancoram o discurso "no mundo", cabe lembrar que o plano de aula é um gênero textual que visa a apresentar um simulacro de uma aula, descrevendo objetivos, atividades, conteúdo, avaliação e o que se passa no contexto escolar, pelo menos no que se trata dos planos de aula disponíveis no Portal do Professor do MEC. Por isso, coloca-se como pressuposto que o espaço tópico onde ocorrerão as atividades descritas no plano seja a sala de aula e que, quando isso não é verdadeiro, esse espaço será especificado

\footnotetext{
40 "Se o tempo deve ser obrigatoriamente manifestado no discurso, e o espaço, não necessariamente, podemos dizer que, ao menos do ponto de vista da manifestação linguística, o espaço está no tempo". (FIORIN, 2002: 296)
} 
pelo enunciador, seja ele o laboratório de informática, a biblioteca, o museu ou a comunidade escolar, conforme observado nas análises individuais dos planos.

Há um plano de aula que especifica esse espaço da aula, o de número 07 que enuncia, logo no início: "Na sala de aula o(a) professor(a) deverá explicar aos alunos o que eles irão fazer no Laboratório de Informática." Os outros planos não especificam a sala de aula, mas o Laboratório de Informática (planos 03, 04 e 07), a escola (planos 05 e 06), a biblioteca (plano 04) e o museu (plano 01). Apenas o plano 02 não traz nenhuma especificação de espaço tópico. Esses espaços sempre se colocam como um não-aqui para onde os alunos poderão ou deverão ir e os planos sugerem ou prescrevem deslocamentos nesse espaço.

Há dois planos de aula que mostram muito claramente um movimento da cena enunciativa da aula no espaço tópico. O plano de aula 05, Debate deliberativo sobre bullying, apresenta indicações de que a aula se desenvolve pela escola, nomeando os espaços relacionados a ela: "comunidade escolar", "ambiente escolar", "toda a escola", "escola", "nossa escola", "pátio da escola". Trata-se de um discurso que constrói uma aula durante a qual se circula e se percorre todo o espaço escolar. No plano de aula 07 , há a indicação de atividades que se fazem em sala de aula e, depois, no laboratório de informática.

Os planos também apresentam um direcionamento do espaço da aula para o exterior, ao apresentarem fontes da internet para consulta, remetendo o enunciatário para fora da sala de aula e para fora dos limites da aula. O enunciador constrói esse efeito de abertura para o mundo e de extensidade do plano de aula com o uso da tecnologia, no espaço digital. Encontram-se, ainda, no plano 01, indicações de circulação das informações: "abrir a roda de discussão", "disseminar o acervo", "divulgar o conhecimento", "disseminar as informações", "[esses gêneros deverão] circular pela comunidade escolar". Elas também fazem acentuar a extensidade desse discurso pelas informações e conhecimentos que percorrem o eixo extensivo "do mundo", para além da sala de aula.

\subsubsection{Os valores que circulam nos planos de aula}


Um dos primeiros objetivos que foram estabelecidos para esta tese havia sido o de buscar nos planos de aula disponíveis online quais eram os valores que neles circulavam, para que se pudesse percebê-los no discurso da educação brasileira no início do século XXI. Esse período, no nosso caso, abarca mais precisamente os anos 2008-2012, ou seja, pouco mais de dez anos após a publicação dos Parâmetros Curriculares Nacionais, os PCN. Ele marca um momento de investimento governamental na disseminação do uso de tecnologias em sala de aula, como se pode verificar não apenas na leitura dos PCN, mas também no tutorial do Portal do Professor para se criar um plano de aula (analisado no capítulo 1), que dedica um grande espaço a ensinar o professor a utilizar os recursos tecnológicos no plano de aula que será publicado.

Primeiramente, coloca-se que o plano de aula consiste na atribuição de uma competência do destinador ao destinatário e na construção de um objeto valor, que vimos chamando de "boa aula". Assim, os valores que se encontram no plano de aula somam-se para compor um valor maior, abrangente, que é a "boa aula". Se no capítulo 1, ao analisar o tutorial de "Como criar uma aula", pudemos verificar o que é uma boa aula para o MEC, na análise dos valores que circulam no plano de aula podemos verificar o que é uma boa aula para os professores, enunciadores do plano de aula. Por meio dessa análise, foi possível depreender duas esferas de valores: os do plano de aula e os da aula que o plano constrói.

Como valores do plano de aula, apontamos dois. Primeiramente, a organização, explicitada no cuidado do sequenciamento das atividades e de seu planejamento. Ainda que não se trate de uma organização padronizada (ela é diferente em cada plano), ela é suficiente para guiar o professor pela aula por meio do uso de advérbios de tempo e de sequenciação e mostra o encadeamento entre as partes do plano. Essa característica do plano assegura seu lugar no eixo dos discursos programados. Em segundo lugar, os acentos de sentido que se colocam em um eixo que oscila entre o deôntico e o volitivo. Interessante lembrar, primeiramente, que, no site Portal do Professor, o plano de aula é chamado de Sugestão de Aula, o que, por si, tende ao volitivo. Com exceção dos dois planos, 04 e 06, que se utilizam exclusivamente de debreagens enunciativas com verbos no imperativo, todos os outros planos trazem "dever" como modalizador, em menor (plano 04, duas ocorrências) ou maior (plano 03, seis ocorrências) intensidade. O plano 05, curiosamente, traz todas as quatro 
ocorrências de dever referentes ao aluno, e nenhuma em relação ao professor. Os outros planos atribuem "dever" tanto ao professor quanto ao aluno. Tendemos a conceber, no entanto, que as instruções ganham um tom que as faz aproximarem-se mais de sugestões, mostrando percursos mais átonos quanto ao dever. Aparecem expressões como "Provoca-se que comentem", "oriente", "Pode-se sugerir que..." e assim por diante. O uso do futuro do presente como tempo verbal também atribui aos enunciados uma característica mais de probabilidade, o que atenua o traço deôntico. A presença abundante nos planos de fontes de pesquisa na internet - com exceção do plano 02 , todos os outros as indicam - também reforça essa característica de um discurso que vai em direção à sugestão, no sentido de que a esse enunciatário são dadas opções outras que não as que estão enunciadas ali. Essa característica faz com que o plano de aula online se construa mais com base em recomendações do que em instruções. Isso está coerente com o fato de que o plano de aula tradicionalmente era feito pelo professor para si mesmo, como documentação de suas intenções e planejamento para a aula e, a partir do momento em que é feito por um professor para ser utilizado por outro, apresenta-se com um traço mais fraco de dever e mais acentuado de sugestão. Pode-se dizer que o plano de aula disponível online traz em si um valor de alternativa à aula que o professor estava acostumado a dar, algo que está contido no campo da possibilidade: ao professor é facultado utilizá-lo.

Como valores da aula contida no plano, que buscávamos como sendo aqueles que circulam pelo discurso da educação brasileira e que podem ser apreendidos por meio do que se planeja para a sala de aula, iniciamos por dois que foram solicitados no tutorial: a centralidade do aluno no processo da aula e a clareza dos objetivos. Desse olhar para o plano de aula como um objeto, pode-se afirmar que emergem valores que sustentam a centralidade no aluno e que mostram o professor como um agente do ensino. Isso pode ser comprovado na análise que mostramos das estratégias discursivas actanciais, da tematização dos lexemas "aluno" e "professor" ao longo dos planos de aula.

Quanto aos objetivos de aula, embora o tutorial pedisse clareza em sua exposição, isso nem sempre é cumprido e, portanto, não se pode dizer que seja um valor que circula plenamente nessa esfera discursiva. O plano 04 faz construir um audiolivro, mas isso não consta nos objetivos, que tratam apenas das questões referentes à poesia. 0 plano 06 não 
mostra nos objetivos que se fará um sarau, parte importante da finalização do processo da aula proposta, e que, por esse motivo, deveria aí estar explicitado. E o plano 07 traz objetivos tão generalistas que não é possível compreender por meio deles o que se pretende naquela aula. Quanto aos demais planos, pode-se dizer que são relativamente claros nos objetivos que propõem.

Sobre os percursos temáticos que estão presentes nos planos de aula online analisados, pode-se dizer que o uso da tecnologia tem presença dominante, apreendida por meio do uso de palavras em inglês pertencentes a essa esfera discursiva (plano 01), de indicação de conexão ao mundo da internet $(01,04,05$ e 07), de indicação de fontes externas para pesquisa (todos com exceção do plano 02) e do laboratório de informática como espaço onde acontecerá parte da aula $(03,04,05$ e 07). Essa presença tônica da tecnologia constrói uma isotopia de leitura entre os PCN, os objetivos do Portal do Professor e os planos de aula.

O tema da cidadania, tema transversal que os PCN solicitam que seja trabalhado, aparece em dois dos planos (02 e 03), porém com pouca ou nenhuma indicação de problematização. Esses dois planos poderiam construir aulas que provocassem nos alunos criticidade, pois trazem nos exemplos textos que possibilitariam discussões sobre consumo, voto consciente, direito ao aborto, a visão do funcionário público como um servidor da população, mas elas não acontecem. Eles primam pela transferência de conteúdos, para nos utilizarmos da expressão freiriana para um ensino acrítico e, por isso, pouco efetivo.

Por outro lado, o tema da exclusão social, que se liga estreitamente à questão da cidadania e é de suma importância para a construção de uma sociedade mais democrática e inclusiva, é tratado em dois planos, 05 e 07. Neles se propõe amplo espaço de discussão e trabalho para seu entendimento, um trabalho abrangente com o aluno, de reflexão individual e em grupo e de ação sobre o restante da comunidade escolar. Acreditamos que um dos motivos de o plano 05 ser o mais acessado e o mais comentado do Portal em Língua Portuguesa seja o fato de ele propor um tratamento tão abrangente para uma temática tão sensível, o bullying.

Para a solicitação dos PCN por uma aprendizagem significativa, que faça sentido imediato para o aluno, encontramos nos planos 05 e 06 duas temáticas que, a nosso ver, ajudam a construir esse valor. No plano 05 , tem-se a proximidade entre professor e aluno 
feita por um diálogo construído por meio da utilização de uma linguagem informal, que busca cumplicidade ao sair da esfera mais pública da aula e adentrar a esfera privada dos afetos. No plano 06 , tem-se a invocação do prazer do aprendizado, que ele propõe que aconteça tanto por parte do professor quanto pelo aluno. O prazer por aprender atribui significação a esse processo porque o insere na esfera do sensível.

Pode-se, assim, colocar que os planos de aula disponíveis online organizam o fazer do professor visando à "boa aula" mais com sugestões do que com prescrições de temas e atividades, e têm como preocupação constante familiarizar o professor com o uso da tecnologia, que perpassa os planos como um valor de modo uniforme. Em conjunto com o uso da tecnologia e permeando o discurso sobre educação construído pelos professores para adentrar a sala de aula, colocam-se questões sobre cidadania, exclusão social e aprendizagem significativa, que constituem valores importantes. Eles fazem construir a "boa aula" vista a partir da concepção do enunciador-professor, no Brasil, no início do século XXI.

Comparando-se a "boa aula" que emerge dos planos com aquela que foi depreendida da análise do tutorial, no capítulo 1, tem-se em comum aulas organizadas, que mostram claramente os percursos de sequenciamento de atividades e que mostram preocupação com a inserção do uso de tecnologias na sala de aula. As partes da aula (objetivos e avaliação) relacionam-se de modo menos coerente do que o tutorial solicitava, como se pôde ver na análise dos objetivos e avaliação no item 3.10.1. Tanto para o Portal do Professor quanto para os enunciadores nos planos de aula, o aluno é central e a aula orbita em torno dele. Os professores explicitam-se como sujeitos responsáveis pelo fazer, enquanto o tutorial, ao colocá-los como sujeitos criativos e inovadores, parece trazer embutida, de certo modo, uma crítica ao fazer que eles tradicionalmente trazem consigo.

\subsubsection{O ator da enunciação no plano de aula disponível online}

Pertencente à semântica discursiva, o ator da enunciação do plano de aula online é formado, a partir da totalidade dos planos, pelas características dos atores da narração de cada um deles que se mantêm no conjunto. Trata-se de um actante da enunciação 
semantizado por meio de temas ou figuras trazidos pelo discurso. Assim, sua apreensão relaciona-se às análises que fizemos da semântica e da sintaxe discursivas, especificadas individualmente nos planos de aula e sumarizadas nos itens anteriores, sobre estratégias discursivas enunciativas e sobre as análises dos valores tematizados e figurativizados que circulam nesses planos. Para desenvolvimento das reflexões sobre ator da enunciação, apoiamo-nos principalmente em Discini (2003, 2004 e 2015) e Barros (2015).

Tem-se, no cabeçalho dos planos de aula, sua identificação, o que antropomorfiza o ator da enunciação, atribuindo-Ihe um lugar no mundo. Por ter junto a seu nome e espaço para foto que o identificam um espaço para nomear a escola à qual pertence, ele se reveste figurativamente como um ator "de carne e osso" pertencente à esfera da educação. A partir dessa figurativização encontrada na totalidade de planos de aula, tem-se um ator da enunciação que se coloca em identidade temático figurativa com o seu enunciatário, mostrando-se como semelhante. O modo como o conjunto de sujeitos se concretiza faz com que o destinatário perceba, ao destinador e a si mesmo, como sujeitos que têm os mesmos valores, o que cria o efeito de identidade partilhada (DISCINI, 2015: 123). Daí decorre o efeito de uma "conversa", que tem lugar em um espaço comum como se fosse a sala dos professores de uma escola, produzindo efeito de realidade, de que aquelas pessoas existem, de que o plano de aula é real e acontecerá. Como efeito dessa iconização, tem-se também a atenuação da percepção da presença do MEC como destinador do universo discursivo escolar que transcende o plano de aula e como portador dos valores a serem transmitidos por meio dele.

Como professores, ambos se revestem desse papel temático de um sujeito que sabe e que ensina, mas há um desequilíbrio em relação à detenção do saber: um professor sabe mais que o outro. Isso complexifica essa relação à medida que se a observa mais atentamente, pois o ator da enunciação, ao mesmo tempo em que se coloca em relação horizontalmente estabelecida, mantém seu lugar de detentor do saber por meio das inúmeras fontes de saber que indica para serem utilizadas no plano - os endereços da internet - e pelas explicações que são inseridas nos planos sobre os temas, de forma que o destinatário perceba de modo mais acentuado o processo de competencialização ao qual está sendo submetido por meio do plano de aula. Além disso, esse enunciador está construindo um objeto de valor com seu destinatário, um objeto do qual ele conhece a totalidade, mas que, para o enunciatário, se 
desvela aos poucos. Por isso, a horizontalidade estabelece-se mais da ordem do parecer do que do ser. Apontamos aqui, para exemplificar, o plano 03, que indica que o enunciatário deve pedir aos alunos para pesquisarem na internet o que é "Coesão Textual" e, ao mesmo tempo, imediatamente explica o que isso significa, ou seja, ele fornece a informação necessária para o professor poder fazer aquela aula competencializado previamente pelo próprio plano de aula, sem necessidade de ter ido buscá-la em algum outro lugar ${ }^{41}$. Esse outro lugar onde se encontraria essa informação, no entanto, está especificado, de modo que, além de funcionar como fonte de informação, essa indicação também se constitui em uma estratégia de persuasão, um argumento de autoridade ao se colocar alguém outro, em um lugar do mundo digital, que dirá o mesmo que está dito no plano. Apontamos também o plano 05, porque traz muitos endereços da internet para uso pelos alunos e pelo professor, o que faz construir um ator da enunciação que conhece o universo virtual e que, portanto, é capaz de guiar o professor e capaz de torná-lo competente para aquela aula. O ator da enunciação do plano de aula online constrói-se como competente e competencializador: ele mostra que sabe fazer e que, por isso, sabe também como seu enunciatário deve fazer. Tratase, então, de um enunciador que, nessa totalidade, parece igual, mas que, na verdade, é quase-igual, pois é "um pouco mais", por deter um saber que o enunciatário quer e que (ainda) não tem.

Para construir-se como um sujeito que pertence ao mesmo universo, o escolar, mas que está um pouco à frente porque sabe mais - porque já fez aquela aula, porque já sabe utilizar as tecnologias digitais que os documentos legais prescrevem para a sala de aula -, o ator da enunciação do plano de aula online faz uso do momento de referência futuro como estratégia discursiva temporal, como mostramos. Desse modo, ao construir o efeito de predição para a aula, ele também acentua para o destinatário sua posição de saber, de alguém que, na linha do tempo, encontra-se em um ponto adiante, alguém que já percorreu o percurso que está propondo que seu destinatário percorra. Ele assume o papel temático do sujeito que prenuncia uma boa aula.

\footnotetext{
${ }^{41}$ Este trecho está reproduzido na análise individual desse plano de aula.
} 
No plano da expressão, esse ator da enunciação mostra-se como um sujeito organizado e regrado. Sua ordem e organização se evidenciam por meio da apresentação das aulas e atividades visualmente segmentadas e sequenciadas. O plano de aula online, tanto como se mostra na tela do computador como impresso em arquivo formato pdf, é dividido em partes: título, data, autor(es) e dados da aula, que por sua vez é subdividida em: "o que o aluno poderá aprender com esta aula", "duração das atividades, "conteúdos prévios trabalhados pelo professor com os alunos" etc. (já vistos em itens anteriores). Cada título de seção está destacado pelo uso de fonte em negrito e por espaço anterior e posterior de uma linha em branco. Essas partes vêm formatadas pelo destinador do site que contém o plano de aula, que enforma esse texto sem flexibilidade ou espaço para alteração, o que se traduz na colocação de limites bem estabelecidos. Os planos que se subdividem em aulas ou atividades também destacam onde inicia cada uma delas, seja em negrito, seja com a utilização de caixa alta, marcando esse percurso de ordem e da organização que, portanto, se reforça como um traço do ator da enunciação do plano de aula online também no plano da expressão.

O uso de fonte de tamanho miúdo e margens estreitas, vistos também tanto em tela quanto impresso, remete a uma maximização de aproveitamento do espaço que se ocupa, a uma economia desse espaço, para se fazer caber mais conteúdo em menor continente. $\mathrm{O}$ ator da enunciação, assim, constrói-se como discreto, econômico e que "fala baixo", em letras miúdas que ocupam pouco espaço - um sujeito "sério", confiável, mais preocupado com a forma do conteúdo do que com a da expressão, e que deve fazer "mais" com "menos". Ele sabe ensinar e sabe ensinar a ensinar, tanto que é capaz de criar uma boa aula. O enunciatário é projetado como um sujeito que é mais seduzido pelo conteúdo do que pela expressão, mais estimulado pelo saber do que por um visual atrativo. É um sujeito que valoriza euforicamente o máximo aproveitamento do espaço, que se identifica com o quadro de valores projetado: ordem, organização, voz baixa e discreta que será ouvida porque respaldada pelo saber que contém. A presença de imagens observadas nos planos 01, 04 e 07 faz querer quebrar um pouco essa "seriedade" e o modo de exprimir-se "econômico" do plano de aula sem, no entanto, descaracterizá-lo. 
Observamos que esse perfil que se constrói faz forte contraste com o ator da enunciação excessivo do discurso da internet, caracterizado por Barros (2016a). Se o ator da enunciação dos blogs e do discurso de intolerância (BARROS, 2016a) "fala alto" e se apresenta intolerante e excessivo, o ator da enunciação dos planos de aula disponíveis na internet fala baixo, com voz modulada e discreta, algumas vezes afetuosa. Por ser personificado tanto sintática quanto semanticamente, esse sujeito se responsabiliza pelo que diz, em contraste com o ator excessivo (ibid.), que não se responsabiliza, esconde-se atrás de apelidos ou mesmo do anonimato. Entre o excessivo e o insuficiente, um termo complexo que tudo abarca. No outro eixo, o não-excessivo e o não-insuficiente, tem-se a dêixis mais átona e, nela, encontra-se a justa medida.

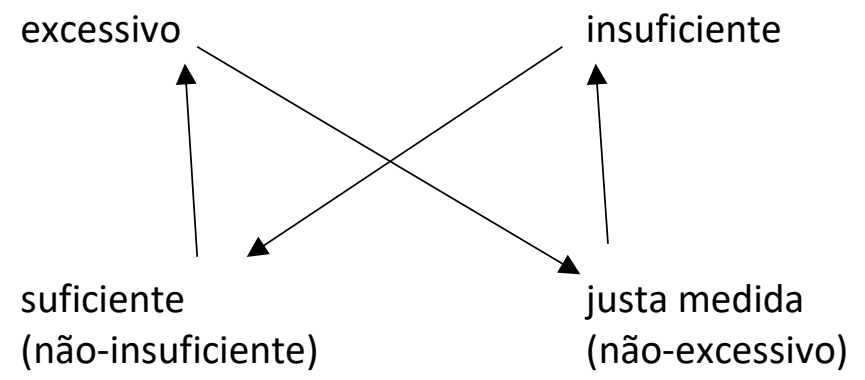

O ator da enunciação do plano de aula online parece buscar a justa medida para o que mostra fazer e para o que mostra ser. A boa aula seria a aula na justa medida, o bom professor, também. Essa justa medida é a característica do medíocre, como qualidade que rege a vida social (FIORIN, 1989), de pessoa educada, prudente, discreta. Colocada no quadrado semiótico, a justa medida ocupa o lugar do termo neutro: não-insuficiente e nãoexcessivo.

Há muitas coisas que, no plano de aula, não são ditas. Não se traz nenhuma polêmica em três planos (01, 04 e 06), há polêmica mostrada mas silenciada em dois planos (02 e 03, conforme comentado anteriormente) e há outros dois (05 e 07) que tratam de assuntos polêmicos no conteúdo da aula, mas o fazem sem mencioná-los nem nos objetivos, nem na avaliação (embora o plano 05 traga o assunto da polêmica no título da aula). Não mencionar os temas sobre bullying e exclusão social nos objetivos está dizendo que o tratamento daquele assunto não está entre as finalidades da aula, que ela visa a outra coisa, como interpretar 
textos e criticar (não se diz criticar o quê) ou debater e apresentar resultados de pesquisas à comunidade escolar. Esse ator da enunciação prefere o baixo risco do silêncio sobre temas sociais importantes e polêmicos. Ele pode até trazer esses temas ao plano, mas, ao dizer pouco ou nada sobre eles, é quase como se não os tivesse trazido. Diz, mas sempre pode dizer que não disse. Ao não querer problematizar, esse enunciador mostra pouca ou nenhuma abertura ao diálogo sobre temáticas da vida em sociedade, o que contribui para que as estruturas sociais se mantenham como são; mostra também receio de se envolver em assuntos que provocariam divergências. Essa estratégia pela qual ele opta, de silêncio, é, portanto, conservadora, movida pelo desejo de não-mudança ${ }^{42}$ e confirma seu posicionamento "do meio", no ponto neutro e átono.

Além disso, ao assinar bilhetinhos no final do plano de aula (plano 07), dizer que o professor precisa ter sido seduzido por Machado de Assis (plano 06) e colocar como objetivo que os alunos "se sentirão valorizados" (plano 05), tem-se um ator da enunciação que adiciona sensibilidade ao plano de aula. Isso provoca ruptura na ordem estabelecida pela programação que rege esse gênero textual e o aproxima do discurso mais subjetivo que se observa, de um modo geral, na esfera educacional. Como referência de discurso afetivo nessa área, podemos citar, trazidos de nossa memória recente, Rubem Alves, Loris Malaguzzi, entre outros autores que privilegiam a dimensão do sensível na pedagogia. Trata-se, frequentemente, de discursos muito adjetivados, descritivos, nos quais abundam verbos de estado e que tendem, por vezes, ao sentimental. Por outro lado, são discursos que, ao se inserirem tão fortemente na dimensão sensível, provocam a adesão do enunciatário. O ator da enunciação do plano de aula sabe disso e traz essa característica do discurso pedagógico para o seu discurso.

Em resumo, o plano de aula tem por ator da enunciação um sujeito que ocupa um lugar na esfera discursiva da educação escolar, que é sério porém afetuoso, que fala baixo e é eficiente no pouco espaço que ocupa. É organizado, regrado e "sabe o que faz". E é um sujeito

\footnotetext{
42 Teria sido muito interessante fazer uma análise aprofundada do silêncio, do silenciamento e do não-dito nos planos de aula, que não nos foi possível desenvolver aqui. Para ela se trariam questões do silenciamento dos professores, pelo lugar de pouco prestígio que ocupam na sociedade, do silenciamento das mulheres ( $70 \%$ do corpo docente brasileiro é feminino) por sua condição na sociedade, e do silenciamento como forma de autoritarismo e opressão, modos de funcionamento de uma sociedade que, depois de pouco mais de trinta anos saída do jugo de uma ditadura militar, volta (ou continua, porém de modo intensificado?) a flertar abertamente com o fascismo, no qual qualquer forma de diálogo é interditada.
} 
conservador, que opta por interações de baixo risco e evita tocar em assuntos polêmicos. Ele se dirige ao professor destinatário da aula com proximidade sem deixar de colocar-se como alguém que tem competência para ensinar a fazer, numa pequena concessividade que faz em relação à identidade partilhada que se construiu. Mais ainda, ele "profetiza" a boa aula, objeto valor visado pelo enunciatário e que será construído ao longo do plano de aula, ao escolher estratégias discursivas que provocam esse efeito de quase-certeza do que acontecerá. O ator da enunciação do plano se constrói como um sujeito que se situa em um lugar suspenso entre a esfera pública e a privada, ao desenvolver uma relação que se aproxima do subjetivo mas que está situada em um lugar institucional ${ }^{43}$. Ele se apresenta como um sujeito que se responsabiliza por seu discurso e que prefere fazer propostas que se aproximam, em sua maioria, de sugestões. Ao buscar a justa medida, faz parecer assemelharse ao sábio, uma pessoa virtuosa que não pende nem ao excesso nem à falta.

\subsubsection{Regimes de interação nos planos de aula}

Segundo Landowski (2014: 66), para se eleger um regime de interação mais adequado para cada caso é preciso levar em conta o contexto e o tipo de interactante que se tem, pois os regimes remetem a modos de estar no mundo. Ele prescreve (idem: 85) que os processos de mutação entre regimes devem ser analisados a partir de corpus textuais precisos ou de práticas observáveis para que se possa apreender o devir estrutural próprio de cada um desses estilos de vida. Para esse semioticista, os sujeitos transitam entre os regimes de interação em relações sintáxicas que perfazem um percurso em forma de elipse ${ }^{44}$. Esse se pode iniciar de duas maneiras: pelo acidente, indo para a manipulação e depois para a programação; pela programação passando para o ajustamento, fechando o circuito no regime do acidente. Assim, os modos ou regimes de interações não são estanques, mas

\footnotetext{
${ }^{43}$ Tendemos a pensar que, nesse mesmo sentido, a escola em nossa sociedade também se encontre nesse "entre-lugar" entre as formalidades públicas e as informalidades privadas, como primeiro lugar de socialização das crianças para fora de suas famílias.

${ }^{44}$ Como se vê no diagrama que reproduzimos no capítulo 2 desta tese.
} 
movimentam-se, obedecendo a regularidades. Buscamos observar essa movimentação das interações pelos tipos de regimes de interação nos planos de aula.

O plano de aula é da ordem da programação, um texto que espelha a construção de um objeto em cuja interação os riscos são calculados e minimizados. O destinatário do plano de aula está programado para fazê-lo, pois ele já chega até esse texto previamente modalizado por um dever ou um querer adquirir uma competência para dar uma boa aula, seu objeto valor. O enunciatário, no regime de programação, é o sujeito que ocupa um papel temático, o de professor.

De acordo com o percurso proposto por Landowski, da programação se iria para o regime do ajustamento, mas o que se observa no plano de aula é o que se poderia chamar mais de "programação menos programada" do que de um ajustamento, propriamente. Isso é observado quando os planos trazem atividades como sugestão, deixando espaço para que o enunciatário, ao qual o enunciador se endereça como um sujeito do saber, adapte as atividades do modo como achar melhor. O plano 05, que propõe o debate sobre bullying, caracteriza-se como aquele que mais se aproximaria de uma interação por ajustamento, por promover a dimensão sensível da interação entre enunciador e enunciatário. O ajustamento é um regime de interação que ocorre na aula, mas não na etapa de seu planejamento, que é a que está espelhada no plano.

Ao assumir o risco da interação por ajustamento, a sintaxe dos regimes de interação aponta que o próximo ponto do percurso é a interação por acidente, regida pela aleatoriedade. Essa interação não aparece nos planos de aula. Se se falasse da aula, sim, haveria espaço para esse regime de interação, por exemplo, na menção que se encontra ao aleatório quando se fala do imprevisto, que aparece no título e no conteúdo da entrevista com o Prof. Fusari, no Jornal do Professor analisado no capítulo 1 desta tese. O título diz "Planejar evita o excesso de improviso pedagógico". O imprevisto se avizinha ao aleatório.

Abrimos neste ponto um parêntese para se tratar da aula e, nela, do imprevisto, e recorremos então à Didática, a parte da pedagogia que se preocupa com "a arte de transmitir conhecimentos, a técnica de ensinar" ${ }^{\prime 5}$. O objeto da didática é o ensino, mais

\footnotetext{
45 Dicionário Houaiss online.
} 
especificamente, a melhor forma de ensinar. Assim, a didática busca não apenas um saberfazer, mas o melhor modo de saber-fazer. O plano de aula disponibilizado online, feito por um professor para outro professor fazer, visa a um saber fazer fazer, transmitindo esse saber fazer, a didática, a outrem. A aula está programada pelo plano, mas o inesperado irá sempre rondá-la - um gracejo fora de hora, uma pergunta capciosa... Além disso, também pode acontecer que uma atividade esteja mal programada, que algo saia de modo estranho.

O sujeito aprendiz está previsto no plano de aula, já que ensinar é, sempre, "ensinar algo a alguém", um verbo transitivo direto e indireto, mas, dentro dos planos que vimos, esse sujeito se insere também na regularidade programada ou na intencionalidade manipulada.

A aula é o lugar da concretização do ensino. É o momento em que o professor executa os procedimentos que havia preparado. Supostamente, um planejamento bem realizado deveria garantir o sucesso e a eficiência desse empreendimento. No entanto, todos nós sabemos que não é bem assim. A nossa experiência de alunos já nos fez perceber que uma aula é uma atividade que se realiza sob risco permanente: um acontecimento imprevisto, uma 'gracinha' de alguém, uma pergunta de um aluno - às vezes sincera, às vezes maliciosa - que gera um mal-entendido com o professor, qualquer acontecimento desses pode fazer uma aula não dar certo. (CORDEIRO, 2015: 34, grifo nosso)

A afirmação de Jaime Cordeiro (2015), estudioso da área de Didática, aponta justamente para o imprevisto, o acidente que está no percurso sintáxico dos regimes de interação. O improviso, resposta do sujeito ao imprevisto, sai do plano, mas está contido no sistema da aula, pois, embora não explicitamente previsto, ele pertence ao mesmo quadro axiológico, segue a mesma gramática, só que na lógica concessiva em vez de na implicativa (ZILBERBERG, 2011). O plano de aula poderia prevê-lo, discuti-lo, mas não o faz. Fecham-se os parênteses.

O percurso dos regimes de interação que se observa no plano de aula não passa, portanto, pelo regime de interação por acidente, voltando diretamente ao regime de interação por manipulação. Cabe ao sujeito, nesse momento, buscar persuadir o destinatário para que os acontecimentos voltem à sua ordem e, por fim, restabeleça-se a programação. Esse percurso que vai do acidente à programação, passando pela manipulação, coloca-se, para o plano de aula, nos moldes de um percurso descendente, de restabelecimento da ordem. 
Sobre o regime de interação da manipulação, podemos tomar a característica apontada pouco acima, de abertura do enunciador em relação ao enunciatário como uma estratégia de manipulação, do regime da intencionalidade. Ao sugerir mais do que instruir, o enunciador manipula o enunciatário para que creia em seu fazer dizendo-lhe que há identidade entre eles porque ele, enunciador, também crê na competência do sujeito com o qual interage. Por outro lado, nos planos de aula em que há menor espaço para o enunciatário como sujeito competente, planos que estão mais para a programação do que para a manipulação, como o plano 03, a estratégia assenta mais sobre a ordem e o dever e tem como efeito de sentido o de segurança para o enunciatário de que a aula se realizará conforme planejado, porque mais programada - e, portanto, envolve menor risco.

Por fim, há também que se considerar que o professor, como o cientista, o pesquisador e outros sujeitos da manipulação e da programação, profissionais que primam pela regularidade, valoriza a virtude da prudência, dêixis positiva formada pelos regimes da programação e da manipulação (LANDOWSKI, 2014: 107). Mas esse aluno de que trata o plano de aula que analisamos, adolescente em idade escolar, a espelho do fazer contemporâneo, tende a valorizar positivamente a dêixis da aventura: do inesperado, do desafio, do risco, do sensível - sensações produzidas por jogos, filmes e séries com os quais interage o tempo todo, ou melhor, pelos quais é afetado o tempo todo. Isso produz um choque de regimes de interação, no embate da sala de aula, na contradição entre gerações e modos de ver e sentir o mundo e resulta em relações problemáticas por essa falta de ajustamento entre o que os sujeitos esperam. Os alunos esperam o inesperado, o professor espera o esperado.

Assim, pode-se dizer que o plano de aula trata da parte da interação que se situa no eixo da prudência e mais próxima do regime da programação e da manipulação, regulando-a, dando-Ihe segurança, mas, por conseguinte, atribuindo-Ihe pouco significado. Na medida em que relega ao professor espaço de adaptação da aula às necessidades do aluno, ele está deixando à sensibilidade do professor a responsabilidade pelo ajustamento, para aproximar a aula do seu aluno a fim de que ela se torne significativa. Para que esse sujeito professor exerça sobre o aluno uma interação por manipulação exitosa, é necessário que eles compartilhem do mesmo quadro axiológico no qual o saber seja um valor eufórico e valorizado positivamente 
dentro e fora da esfera escolar. Para Landowski (2014: 93) "[...] toda manipulação consiste do mesmo modo em fazer outrem desviar-se de sua trajetória para orientá-lo a um projeto de atividade que para ele está 'fora do programa'". O saber como valor eufórico muitas vezes está fora do programa do aluno e, portanto, fora de seu quadro de valores. A persuasão para fazer desse um objeto de valor positivo e desejado deveria ser não apenas uma tarefa de um sujeito professor em sala de aula, mas uma tarefa coletiva, da sociedade.

\subsubsection{Sobre o uso da tecnologia observado nos planos de aula analisados}

Para finalizar este capítulo de análise, observa-se, sobre o uso da tecnologia nos planos de aula, que se trata de planos que, quase todos, bem atendiam à solicitação dos PCN e do próprio site, visando a familiarizar o enunciatário professor e seus alunos com usos da tecnologia, como visita a sites da internet e extração de informações relevantes (plano 01), pesquisa na internet sobre um determinado conceito (planos $03,05,06$ ), assistir a vídeos para posterior análise (plano 07), gravação e publicação de áudio na internet (plano 04). Ainda, quase todos os planos trazem endereços de sites na internet para que o professor possa encontrar mais informações sobre os temas de que se ocupam, o que, provavelmente, na atualidade, se faz muito menos relevante ou até mesmo desnecessário, mas que, na época, configurava um importante modo de estabelecer o contrato de confiança entre enunciatários e de construir a competência do destinatário.

Se esses hoje nos parecem usos muito elementares da tecnologia, é preciso, mais uma vez, lembrar que esses planos foram publicados entre 2009 e 2012, localizando-se em uma época em que se iniciava essa relação entre o ensino nas escolas e a tecnologia e que, por isso, tratava-se de um tema muito relevante para a época e a abordagem que faziam dela nos parece necessária e suficiente.

Para o capítulo 4, propomos pensar nos usos da tecnologia mais adequados ao momento atual, início da terceira década do século XXI, com as questões que nos chegam como a aceleração do tempo, a profusão quase infinita das fontes de informação e o necessário olhar crítico para a qualidade dessas fontes. 


\section{A tecnologia digital em sala de aula: reflexões e propostas}

Ao final do capítulo 3, quando encerramos as análises de cada um dos planos de aula disponíveis online e a análise comparativa entre eles, verificamos que o uso da tecnologia que se observava nos planos era condizente com o estágio de desenvolvimento da tecnologia de então, e a maior preocupação, expressa tanto nos PCN quanto no tutorial do Portal do Professor para se criar uma aula, era com a familiarização dos docentes e discentes com o uso das tecnologias e da internet. De fato, os planos analisados mostraram que a familiarização tinha como sujeito não apenas os discentes, como solicitavam os documentos oficiais, mas, também, e talvez principalmente, os docentes. No entanto, o que se observa desde a publicação desses planos de aula foi uma grande evolução nos usos da tecnologia e em sua presença nas escolas, nas salas de aula e, principalmente, na vida de toda a sociedade, na qual se incluem, de um modo que requer muito cuidado, os estudantes. Essas mudanças processam-se de modo acelerado e suas características e consequências têm sido objeto de estudos e análises pelas mais diversas áreas do conhecimento.

Para este capítulo, no qual pretendemos discutir como a semiótica pode contribuir para se fazer melhor uso da tecnologia digital em sala de aula, iniciamos com a reflexão de Hannah Arendt (2014 [1954]) sobre a crise na Educação, pois se trata de um texto que traz questões ainda muito pertinentes para se pensar os problemas que surgem a partir das rupturas provocadas pela intensificação da presença da tecnologia no cotidiano escolar. Arendt detecta a crise da educação como resultando de uma crise mais profunda do mundo 
moderno de perda da tradição e da autoridade (DALSUET, 2007: 51) e afirma que, na educação, isso se reflete na perda de autoridade do professor. Atualmente, a tecnologia intensifica a perda de autoridade do professor destituindo-o do papel de fonte do saber, e rompe com limites antes mais bem estabelecidos para o mundo físico, como o conceito de verdade, por exemplo. Além disso, as colocações de Arendt para o mundo pós-guerra sobre a necessidade de se conservar uma parte desse mundo e, ao mesmo tempo, permitir à nova geração renová-lo aplica-se de modo bastante adequado ao mundo anterior ao uso da tecnologia digital de modo tão intenso pela sociedade e o mundo atual. Em seguida, buscamos em Haroche (2005) a ligação entre a crise da educação como pensada por Arendt e a transmissão do saber na sociedade contemporânea e, depois, trazemos para a discussão as contribuições de Alonso (2019a) para se pensar semioticamente o conceito de crise.

Na sequência, reflete-se sobre o uso da tecnologia digital em educação a partir da prescrição dos documentos legais, analisados no capítulo 1, e de seu uso nos planos de aula analisados no capítulo 3. A partir disso, recorremos aos estudos de Diana Barros $(2015 ; 2016)$ sobre como se caracteriza o discurso na internet para pensarmos de que modo o sentido que se produz nos discursos da área de educação são modificados em decorrência de sua circulação no meio digital. Somos levados a essas reflexões guiados pela hipótese de que a teoria semiótica do texto, com seu modo de explicitar a gramática que subjaz à construção do sentido na sociedade, pode ajudar a se pensar melhores modos de se usar a internet como meio de circulação e instrumento de aquisição de saber, bem como apontar questões ligadas à crise na transmissão do saber que possam contribuir para o debate contemporâneo sobre educação.

\subsection{A crise na educação e no modo de pensar contemporâneo}




\subsubsection{Arendt e a crise na educação}

Embora não seja uma filósofa da educação, Hannah Arendt (1906-1975) publicou, na década de 1950, um pequeno texto chamado Crise na Educação (2014 [1954]) que se tornou uma referência para se pensar sobre as mudanças na educação no mundo ocidental pósguerra. Arendt o concebeu a partir da observação do cenário nos Estados Unidos, onde morava, e insere essa questão em um panorama mais amplo, da vida política, social e da transmissão de cultura na linha do tempo e entre gerações. Suas reflexões são consideradas fundamentais para todos os que desejem refletir não apenas sobre a crise da educação do mundo contemporâneo, mas sobre o próprio sentido de educação na sociedade (CÉSAR, 2014: 37).

Educação como transmissão de cultura, e aqui nos apoiamos na leitura de Arendt feita por Bárcena (2016) para afirmá-lo mais assertivamente, é um conceito que se apreende dessa filósofa a partir do modo como ela coloca a educação como o estabelecimento da continuidade do mundo entre gerações e que se liga estreitamente ao conceito de educação que tomamos no início desta tese e com o qual vimos trabalhando, de Gauthier e Tardiff (2014). Desse modo, pensa-se a educação inserida no eixo do tempo, em um jogo de equilíbrio que se coloca entre o passado e o futuro, entre a apresentação à criança de um mundo existente e seu preparo para um mundo que será construído por ela a partir da educação que recebeu. Para Arendt (2014), esse equilíbrio solicita, ao mesmo tempo, a responsabilidade pelo desenvolvimento da criança e a responsabilidade pela conservação do mundo. Elas podem ser conflitantes porque a responsabilidade pela criança volta-se contra o mundo, já que é necessário cuidar dela e protegê-la para que nada de destrutivo, por parte do mundo, Ihe aconteça, e, ao mesmo tempo, o mundo necessita de proteção para que não seja destruído pela irrupção do novo que chega com cada geração.

A filósofa reitera essa questão do seguinte modo (2014: 242):

A fim de evitar mal entendidos: parece-me que o conservadorismo, no sentido de conservação, faz parte da essência da atividade educacional, cuja tarefa é sempre abrigar e proteger alguma coisa - a criança contra o mundo, o mundo contra a criança, o novo contra o velho, o velho contra o novo. 
Nesse sentido, pode-se colocar que a educação configura-se como um termo complexo, que ao mesmo tempo preserva e transforma o mundo e as pessoas. Daí a grande dificuldade de se lidar com ela, que muda a cada nova geração.

Logo na sequência, Arendt complementa essa ideia falando da necessidade da reordenação constante do mundo (idem: 243):

Basicamente, estamos sempre educando para um mundo que ou já está fora dos eixos ou para aí caminha, pois é essa a situação humana básica [...]. 0 mundo, visto que feito por mortais, se desgasta, e, dado que seus habitantes mudam continuamente, corre o risco de tornar-se mortal como eles. Para preservar o mundo contra a mortalidade de seus criadores e habitantes, ele deve ser, continuamente, posto em ordem. [...] Exatamente em benefício daquilo que é novo e revolucionário em cada criança é que a educação precisa ser conservadora; ela deve preservar essa novidade e introduzi-la como algo novo em um mundo velho, que, por mais revolucionário que possa ser em suas ações, é sempre, do ponto de vista da geração seguinte, obsoleto e rente à destruição.

Para Arendt, é o educador quem tem o ofício de ser o mediador entre o velho e o novo e que, para que ele possa exercer esse papel, a educação não poderia abrir mão da tradição nem da autoridade. Esta última, para a autora, compõe, junto com a liberdade, os dois conceitos políticos centrais e inter-relacionados (ibid.: 42), necessários para que se possa pensar as rupturas sociais ocorridas no século XX e para se caminhar em um mundo que não é mais estruturado pela autoridade nem mantido coeso pela tradição. Arendt nos lembra (idem: 129) que, por exigir sempre obediência, a autoridade é muitas vezes confundida com o poder ou a violência, mas que se houver uso de força, já não se trata mais de autoridade. Ela também não pode ser confundida com a persuasão, que pressupõe igualdade e opera a partir de argumentos. A definição de autoridade deveria ser feita tanto em contraposição à coerção pela força quanto à persuasão por meio de argumentos. A autoridade do professor, para Arendt, não é da ordem do poder, o qual seria possível tomar, mas da ordem da competência e da responsabilidade. Como explica Dalsuet (2007: 65):

Arendt cuida de diferenciar a autoridade do educador da competência do professor para tornar mais precisa sua demonstração. Se a competência consiste no conhecimento do mundo, a autoridade remete ao exercício da "responsabilidade do mundo". [...] Ele [o professor] pode efetivamente 
assumir, por causa de sua posição de adulto, essa apresentação do mundo como se fosse seu autor. ${ }^{46}$

Para Arendt (2014: 246), a saída passa por separar o âmbito da educação dos demais âmbitos da sociedade, porque seu funcionamento é diferente e precisa ser mantido com essa atitude de reverência em relação ao passado. Ela afirma que a educação não pode ser colocada na esfera política, porque na polis as relações se dão entre iguais, e esse não é o caso da educação, e critica que os adultos tenham aberto mão de seu papel de autoridade junto às crianças, situação que, da segunda metade do século XX (quando seu texto foi escrito e publicado) para cá, só parece ter se acentuado.

A conclusão a que chega Arendt em seu ensaio é a da educação como responsabilidade sobre o mundo (2014: 247):

A educação é o ponto em que decidimos se amamos o mundo o bastante para assumirmos responsabilidade por ele e, com tal gesto, salvá-lo da ruína que seria inevitável não fosse a renovação e a vinda dos novos e dos jovens. A educação é, também, onde decidimos se amamos nossas crianças o bastante para não expulsá-las de nosso mundo e abandoná-las a seus próprios recursos, e tampouco arrancar de suas mãos a oportunidade de empreender alguma coisa nova e imprevista para nós, preparando-as em vez disso com antecedência para a tarefa de renovar um mundo comum.

Há duas ideias fundamentais nessa reflexão de Hannah Arendt que serão tomadas como base para o modo como propomos pensar a presença e o uso da tecnologia em sala de aula. Primeiro, a ideia de que à educação cabe mediar o mundo velho e o mundo novo, o que nos leva a trazer essa concepção para o mundo contemporâneo e opor o mundo físico ao digital, emergente, presente de modo cada vez mais forte não só na vida social mas também na educação, ou vida escolar, se quisermos assim especificá-la um pouco mais. A segunda é a ideia da perda de autoridade por parte do professor, que se insere, na visão da filósofa, na renúncia dos adultos à responsabilidade.

\footnotetext{
${ }^{46}$ Tradução livre. Original: Arendt prend soin de différencier l'autorité de l'éducateur et la compétence du professeur pour préciser sa démonstration. Si la compétence consiste en la connaissance du monde, l'autorité renvoie à l'exercice de la "responsabilité du monde". [...] II [le professeur] peut en effet assumer, par son statut d'adulte, cette présentation du monde comme s'il en était l'auteur.
} 


\subsubsection{A crise na transmissão do saber na contemporaneidade}

Antes de abordarmos a transmissão do saber, cabe uma breve ressalva direcionada a uma crítica que se observa, por vezes, na educação brasileira, que não acolhe bem esse termo por tomá-lo como sinônimo de transferência de conhecimento. Para o patrono da educação brasileira, Paulo Freire (2016), "ensinar não é transferir conhecimento", o que ele aponta como um fazer da ordem da "educação bancária" - aquela em o professor "deposita" o saber no aluno, que se mostra passivo, não dotado de um querer ou de um querer-saber. Não é disso que se trata quando se fala em transmissão do saber, mas sim de algo que antecede, e complementa, a construção do conhecimento. O ensino - o fazer saber e o fazer fazer - se faz da mescla entre construção de conhecimento e sua transmissão, que se tem chamado de transmissão da cultura (GAUTHIER e TARDIFF, 2014). Afinal, não se faz o aluno reinventar o conhecimento a cada vez que ele tenha que aprender alguma coisa, mas se mostra a ele o que a cultura já possui como realização, para que ele possa, a partir desse conhecimento adquirido, prosseguir. Nas palavras de Arendt (2014), a transmissão do saber aproxima-se da apresentação do mundo, do que é velho e, acrescentamos, basilar na vida da sociedade, para o educando.

Claudine Haroche $(2005 ; 2008)^{47}$ nos traz importantes reflexões sobre como os modos de a sociedade contemporânea lidar com a informação têm se refletido sobre a transmissão do saber e o crescimento do saber não cumulativo. Ainda que suas considerações estejam mais voltadas ao âmbito universitário, é possível dizer que essa crise encontra-se também infiltrada nas esferas escolares de reprodução do conhecimento, perceptível a partir das premissas colocadas por Hannah Arendt que expusemos acima. Suas ideias também estabelecem diálogo com as de François Rastier sobre a semiótica da transmissão (2015), da qual falaremos a seguir, pois transmissão do saber e transmissão cultural podem ser tomadas como termos equivalentes, e mesmo como sinônimos em alguns contextos.

\footnotetext{
${ }^{47}$ Ambos os artigos têm o mesmo título, mas foram publicados em momentos diferentes: uma versão em português em 2005, na Revista Educação e Pesquisa, e uma versão em 2008, na Revista Cahiers internationaux de Sociologie. Esta segunda, mais enxuta e mais bem acabada, nos serviu como apoio para melhor compreensão das ideias do artigo de 2005 , que nos guiou e que foi de onde extraímos a maior parte das citações e referências.
} 
O questionamento trazido por Haroche $(2005 ; 2008)$ parte da constatação de que a sabedoria, que teria nos mais velhos e, de modo especial, nos professores os sujeitos nos quais ela se deposita, está em vias de desaparecer, o que se liga a dois fatos. Primeiro, de que a informação, atualmente, só vale pelo instante em que é nova, o que tem um efeito profundo sobre a transmissão do saber e contribui para o desenvolvimento de um saber nãocumulativo, que coloca em xeque não apenas a possibilidade do ensino, mas também do conhecimento e do sentido. Segundo, da perda da tradição romana de exaltação da velhice como o apogeu da vida humana, devido ao saber e à experiência adquiridos, e também devido à maior proximidade do idoso em relação aos ancestrais e ao passado (HAROCHE, 2005: 349). Ela propõe, a partir dessa constatação, um questionamento sobre quais efeitos os movimentos contínuos da fluidez das formas de sentir e pensar atuais têm sobre a consciência e sobre a capacidade de pensar e refletir. A sabedoria, decorrente do saber reflexivo e cumulativo, está desaparecendo e, com isso, o processo de apropriação e de transmissão dos saberes nas sociedades contemporâneas é perturbado pelo fluxo incessante de informações, o que:

[...] contribui para formas inéditas de individualismo, acarreta uma fragmentação, uma dispersão, um descomprometimento que obstrui de certo modo a continuidade, o sentimento de si mesmo [...]. Como desde então poucos conhecimentos são considerados adquiridos, definitivos, essas condições previnem a possibilidade de um saber cumulativo, provocam incerteza - uma incerteza às vezes radical - quanto a si mesmo e quanto ao outro, abrindo caminho para uma insegurança psíquica profunda. (HAROCHE, 2005: 350)

Haroche complementa dizendo que o caráter contínuo das sensações, privilegiado em detrimento do plano das ideias e juízos, tenderia a diminuir ou mesmo impossibilitar o pensamento e a reflexão (idem: 352). As formas contemporâneas de percepção ligam-se muito profundamente à velocidade, à aceleração e à tecnologia, induzindo, segundo a socióloga, à contingência, à instabilidade e à incerteza que se encontram no coração da crise da educação e da cultura. Assim, a crise da consciência contemporânea (cujas origens Haroche busca em Locke, Husserl e em Arendt e depois desenvolve apoiada em Weber) acentua-se pela aceleração do tempo que se tem hoje e origina-se no fato de que não se investe mais tempo no aprofundamento das questões científicas, em ir além dos fatos, de 
compará-los e discerni-los. Também a subjetividade foi deixada de lado em nome de uma redução da ciência a uma "ciência dos fatos", alojando-os na superfície em vez de aprofundarse no conhecimento. Desse modo, tem-se uma acumulação irrefletida de informações (2005: 353) e um crescimento do que ela denomina saber não cumulativo.

Sobre as dificuldades de pensar nas condições contemporâneas de educação, Haroche aponta para a excessiva compartimentalização dos saberes, o que leva a um pensamento "repetitivo e prudente" (2005: 356). Leva também o indivíduo a querer ser informado, especializado e experiente para o mercado, em vez de educado e instruído. Podemos observar nesse ponto que a língua portuguesa nos permite pensar que se tem um sujeito que quer estar informado e especializado, em condição provisória e efêmera como a informação, em vez de um sujeito que quer ser instruído e educado, em condição mais permanente, resultante de um processo de formação. Haroche critica a falta de capacidade de aprender, pois:

aprender supõe a capacidade de comprometer-se e de pensar, de projetarse no futuro, o que exige e estimula a dúvida, o lugar, o risco de erro, o que implica a existência de uma relação no limite, a consciência de limites individuais [...]. (HAROCHE, 2005: 356)

Colocam-se, assim, em polos opostos, de um lado, o saber universal e refletido produzido na universidade e, do outro, os saberes profissionalizados e experientes que se submetem à razão da economia de mercado. Ilustra essa diferença, na universidade, o imperativo da necessidade de publicações e comprovações de produção exigidas atualmente, em uma cultura de avaliação que visa a um controle administrativo e que deixa pouco (ou nenhum) tempo para a reflexão em questões mais profundas e que demandariam maior e mais prolongado esforço. Poderíamos acrescentar que, nas escolas de ensino fundamental e médio, isso se traduz em uma exigência de que os saberes sejam imediatamente úteis, como, por exemplo, que visem à aprovação no exame de ingresso em universidades. Volta-se, portanto, à questão do tempo da pausa, necessário à aquisição e assimilação dos saberes, e do tempo do instantâneo da informação; um, medido em profundidade e duração e o outro, em extensão e superfície, segundo a autora (2005: 357, com base nas ideias de Lindsay 
Waters $\left.{ }^{48}\right)$. Acresce-se ainda a essas ideias, complementarmente, a lembrança de que o sistema neoliberal busca suprimir tudo o que não seja útil ou rentável em horizonte imediato de aplicação (ibid., idem), ao que complementamos que para se chegar ao horizonte imediato é necessária uma aceleração, o que causa uma diminuição do campo de apreensão do sujeito (ZILBERBERG, 2011).

Também Rastier (2015) lamenta os problemas resultantes da submissão da transmissão do saber à economia de mercado, ao apontar a destituição, no saber, do lugar da dívida simbólica, substituída pela dívida financeira e gerando uma perda do interesse do aluno pelo aprender. Ao propor que o objeto da transmissão seja qualquer objeto cultural, Rastier (2015: 88) a coloca como, mais do que uma simples tradição, aquilo que produz o sentido a partir de sua recontextualização, transformação, reelaboração e interpretação. Ligando transmissão cultural ao conceito psicanalítico de dívida simbólica, o autor formula a hipótese de que o objetivo da educação seja abrir essa dívida simbólica que integre a criança ao grupo social. A troca ( l'échange) social não se constrói a partir do redutivo ponto de vista econômico da sociedade liberal contemporânea de ganho ou perda, mas sim dentro da ideia do sistema de dádiva estabelecido coletivamente (o conceito de don et contre-don, de Marcel Mauss ${ }^{49}$ ).

Dádiva e contra-dádiva fundam e enquadram as trocas, mesmo econômicas, mas o pensamento econômico-liberal contemporâneo acostumou o público a enxergar na troca apenas a sua redução economista, a perspectiva do ganho ou da perda - e não isso que poderíamos chamar de seu valor de uso, que transforma a transações em um momento de vínculo social e de uma prática de viver-se-junto. ${ }^{50}$ (RASTIER, 2015: 86)

A transmissão cultural configura-se, portanto, como essa troca simbólica, uma dádiva que não pode ser objeto de uma contra-dádiva que responda a ela, e abre essa dívida

\footnotetext{
48 WATERS, L. Enemies of promise. Chicago: University of Chicago Press, 2004. O autor é editor de humanidades da Editora Universitária de Harvard.

49 Para esse conceito nos apoiamos na leitura do verbete "Ensaio sobre a dádiva", da Enciclopédia de Antropologia (online). SERTÃ, Ana Luísa e ALMEIDA, Sabrina. 2016. "Ensaio sobre a dádiva". In: Enciclopédia de Antropologia. São Paulo: Universidade de São Paulo, Departamento de Antropologia. Disponível em: <http://ea.fflch.usp.br/obra/ensaio-sobre-dádiva> acesso em março de 2020. E também em: MARTINS, Paulo Henrique. A sociologia de Marcel Mauss: dádiva, simbolismo e associação. Revista Crítica de Ciências Sociais. N. 73 (2005). pp.45-66). Disponível em https://journals.openedition.org/rccs/954 acesso em março de 2020.

${ }^{50}$ Tradução nossa. Texto original: Don et contre-don fondent et encadrent les échanges, même économiques, mais la pensée économique libérale contemporaine a accoutumé le public à ne voir dans l'échange que sa réduction économiste, la perspective du gain ou de la perte - et non ce que l'on pourrait appeler sa valeur $d^{\prime} u s a g e$, qui fait de la transaction un moment du lien social et une pratique du vivre-ensemble.
} 
simbólica que afeta qualquer um que seja portador de uma palavra importante que the tenha sido transmitida, importância essa "medida em função de seu grau de elaboração e dos valores que ela porta" (idem: 88$)^{51}$. Ao se pensar a questão educacional a partir dessa perspectiva de transmissão cultural, a transmissão do saber geracional, pensada em termos da dádiva (a obrigação social entre coletividades de dar, receber e retribuir) que dá origem a uma dívida simbólica, Rastier provoca que se olhe para o mercado da educação, no qual há valores financeiros estabelecidos para tudo e, por isso, há o apagamento dessa dimensão simbólica e significativa do saber, cujo significado se torna átono. Ele adiciona que a dívida econômica não pode substituir a dívida simbólica. Esta, por mais que se busque vender o que não tem preço ou quantificar a qualidade, trata de uma totalidade de lugares e épocas, do crescimento cumulativo de um universo cultural que se constitui em, ao mesmo tempo, objeto de aprendizagem e espaço da transmissão.

A questão, tanto para Haroche quanto para Rastier, é a confusão que nasce do fato de a lógica do mercado, ou da gestão, ser aplicada ao ensino e à educação, pois se trata de universos distintos cujos funcionamentos são diferentes e que a transmissão do saber e da cultura perde muito quando submetida a essa lógica imperativa. Adiciona-se, para Haroche, que a crise da transmissão do saber decorre da aceleração do tempo que se dispõe para apreensão de informações e da proliferação delas, o que gera instabilidade e incerteza nos sujeitos contemporâneos e, em decorrência disso, impossibilita a construção do conhecimento.

Como consequência, a sabedoria perde seu valor e, com ela, se esvai a autoridade do professor e dos mais velhos. Além disso, ao se estabelecer uma dívida financeira no lugar de uma dívida simbólica, substituem-se os laços sociais por compromissos financeiros, que ao serem quitados fecham o ciclo de responsabilidade. A crise de autoridade que Arendt atribui à falta de responsabilidade dos adultos pelo mundo relaciona-se ao fato de a educação ter se tornado objeto de comércio, estabelecido por esses mesmos adultos que escolheram substituir a dívida simbólica pela financeira, que aí se encerra.

\footnotetext{
${ }^{51}$ Tradução nossa. Original: "importance mesurée en fonction de son degré d'élaboration et des valeurs qu'elle porte."
} 
Estabelecem-se, a priori, duas ligações entre a reflexão sobre a crise do saber contemporâneo e os planos de aula que estudamos. Por um lado, não podemos deixar de apontar que o fato de se ter planos de aula publicados online, compartilhados com outros professores - e, portanto, consumidos (se há oferta é porque há demanda) - pode ser visto como resultado dessa aceleração do tempo contemporâneo, que diminui o tempo que se teria para concepção de uma aula ou de um curso (que, a rigor, deveriam ter sido elaboradas por aquele que conhece o conteúdo e o destinatário), e, ao mesmo tempo, resultado dessa demanda por mais produção, pela inserção em sala de aula de recursos (tecnologias digitais, por exemplo) que o professor em geral pouco conhece ou domina, mas que tem o dever de utilizar. Esse dever se dá em nome da contemporaneidade que demanda a uniformização do que se produz nas escolas e de uma urgência em se estar sempre em posse ou em uso do "novo" - lembrando o que foi trazido por Haroche (2005), que a informação vale apenas enquanto é nova. Por outro lado, apresenta-se uma questão positiva, o fato de se compartilhar planos de aula entre professores faz com que esse compartilhamento construa um lugar comum entre os docentes, no qual a troca enriquece as relações, os indivíduos e a aula, produto desse compartilhamento. Não sendo essa troca objeto de transação econômica, como é o caso dos planos que constituem este corpus, ela acaba se encaixando como geradora de uma dívida simbólica, o que pode gerar mais trocas, num ciclo positivo de compartilhamento dos modos de transmissão do saber. Fica como questão em aberto a necessidade de uma desaceleração do tempo do sujeito aprendiz, para que possa acontecer a sedimentação dos saberes que lhe são endereçados, tarefa que cabe à escola, como representante do "velho mundo" que carrega simbolicamente esses saberes advindos da profundidade e da reflexão.

\subsubsection{Sobre crise e educação}

Uma crise nos obriga a voltar às velhas questões mesmas e exige respostas novas ou velhas, mas de qualquer modo julgamentos diretos. Uma crise só se torna um desastre quando respondemos a ela com juízos pré-formados, isto é, com preconceitos. Uma atitude dessas não apenas aguça a crise como 
nos priva da experiência da realidade e da oportunidade por ela proporcionada à reflexão. (ARENDT, 2014: 223)

Juan Alonso, em seu artigo Crise e Imprevisibilidade (2019a), nos coloca que, nos momentos de grandes mudanças históricas, os eventos passam a se desenrolar de modo imprevisível, contrariando a previsibilidade com que se sucedem nos momentos de calmaria. Esses momentos, também chamados de crises, produzem-se dentro dos sistemas e mostramse como pertencentes à ordem concessiva, caracterizada pela descontinuidade e pela imprevisibilidade, em uma sintaxe do sobrevir, em contraposição aos momentos que podem ser denominados "de calmaria", que operam sob a lógica implicativa, da continuidade (conforme Zilberberg, 2011).

A compreensão de crise como um evento concessivo responde bem à citação de Arendt trazida logo acima, que, colocada em termos tensivos, está dizendo que se as respostas para a crise são tomadas com base na lógica implicativa (com os "conceitos pré-formados") perde-se a oportunidade que ela traz de ressignificação para os conceitos que já estavam em jogo. Conforme Alonso (2019a), é com a aparição de uma nova teoria (nascida da crise), que o passado será reinterpretado à luz dos eventos atuais.

Para os problemas que se vivem na educação hoje, entretanto, não caberia mais usar a palavra "crise", pelo fato de que eles são fruto de décadas de descaso com o sistema educacional público e decorrentes de processos de desvalorização da carreira docente, entre outras coisas. Ou seja, inserem-se numa lógica implicativa, do esperado, e, portanto, fora do conceito de crise que se tem e que vimos explicitado, por meio da metalinguagem semiótica, por Alonso (idem). No entanto, esse vocábulo é ainda não apenas utilizado, como também ajuda a justificar, segundo César e Duarte (2010), os numerosos processos de reforma aos quais a educação brasileira é submetida ${ }^{52}$. Não precisamos ir longe para verificá-los: a BNCC, publicada em 2017, altera o entendimento do processo de ensino aprendizagem passando a falar não mais de objetivos de aprendizagem, como os PCN de 1998, mas de habilidades e

\footnotetext{
52 Não podemos deixar de nos reportar à famosa frase de Darcy Ribeiro: "A crise da educação no Brasil não é uma crise, é um projeto", para dizer que o antropólogo brasileiro enxergava as relações entre os descasos de que a educação era alvo e os pífios resultados que ela apresentava e via neles uma continuidade.
} 
competências. Para César e Duarte (2010), o argumento de crise é fundamental para sustentar o projeto disciplinar e para delinear a operação por meio do processo "crisereforma". Baseado no conceito desenvolvido por Foucault ( $1984^{53}$ apud César e Duarte) de que o funcionamento da sociedade disciplinar pressupõe um estado de crise permanente, eles explicam que a aplicação de dispositivos disciplinares depende justamente da constatação da falta de disciplina, ou seja, da crise. Assim justificam-se as ações que fazem da mudança de rumos uma constante na educação brasileira, o que impossibilita a continuidade que the discursivizaria os feitos na extensidade do mundo e permitiria a apreensão do seu sentido, para que fossem feitas as correções de rumo necessárias e que se desse a compreensão do sistema em que funciona, com suas falhas e virtudes.

Quanto à crise na transmissão do saber, pensamos que a categorização como crise, nesse contexto, decorre da experimentação que ainda se faz do uso da tecnologia para esses fins e dos seus efeitos sobre os processos formativos e educativos por meio dos quais se transmite (e se constrói) o saber. Ao ter adentrado a esfera educacional de modo tão intenso e célere, a tecnologia digital trouxe consigo novos modos de se tratar o conhecimento, a pesquisa, as fontes do saber em sala de aula e, por isso, provoca o estabelecimento de novos paradigmas para se lidar com essas questões.

Ainda, cabe-nos trazer mais duas observações que julgamos importantes a respeito de "crise". Para Boaventura de Souza Santos (2019), o modelo neoliberal cria a ideia de que há uma crise permanente, o que é fundamental para manter as pessoas em estado de alerta e sem alternativas, aceitando, portanto, tudo aquilo que precisa ser imposto porque "há uma crise". Corrobora essa ideia o professor de Direito e autor de Crise e golpe ${ }^{54}$ Alysson Mascaro (2020) para quem "o capitalismo opera na crise". De tal modo, sem aparentes alternativas, justificam-se pela crise, de antemão, a má qualidade e os problemas enfrentados na esfera educacional, como também afirmam César e Duarte (2010). Essas duas concepções de crise como modus operandi relacionam-se intimamente à aceleração do tempo, característica geradora das questões colocadas por Claudine Haroche (2005) para pensarmos que, se há uma crise na educação, ela decorre da urgência e da temporalidade imediata que se colocam

\footnotetext{
53 FOUCAULT, M. Vigiar e punir. Rio de Janeiro: Vozes, 1984.

54 MASCARO, Alysson. Crise e golpe. São Paulo: Boitempo, 2018.
} 
no campo educacional e também faz com que, como consequência, se tenha ainda maior aceleração e urgência para que se "resolvam" os problemas por ela gerados. Nos parece clara a necessidade de discursivização das alegadas crises - a da educação e a da transmissão do saber - para que, uma vez que possam ser observadas de modo mais extenso em relação ao tempo e ao espaço em que se encontram - se encontrem novas respostas para os problemas em vez de se insistir, como apontamos no início deste item na citação de Hannah Arendt, em usarmos de conceitos formados para buscar responder a novas questões. Seria necessário que se distinguissem pontos no percurso nos quais seria preciso desacelerar para construir diferentemente, donde decorre que os trabalhos feitos pela coletividade se vejam fundamentais: alguns sujeitos continuam, outros param para analisar (no tempo da pausa a que Haroche (2005) se refere), os dois grupos se encontram em pontos de verificação para que possam seguir juntos, em trajetórias que se complementam e beneficiam a todos. Em vez de se falar em crise e, portanto, almejar a ruptura, buscar-se-ia a continuidade no coletivo, de modo que os saberes e as informações, cada um com seu valor diferente, possam coexistir: os saberes como mais reflexivos e permanentes, as informações como mais imediatas e efêmeras.

\subsection{Tecnologia digital em educação ${ }^{55}$}

As escolas, ao mesmo tempo em que buscam trazer a tecnologia digital para seus alunos, seja levando-os ao laboratório de informática, quando disponível, seja adotando tablets no lugar de livros didáticos e criando espaços na rede digital para disponibilização do conteúdo das aulas e de exercícios para os alunos ${ }^{56}$, são também, por excelência, as guardiãs do passado e dos modos de operação do mundo offline, pois lhes cabe ensinar, entre outros,

\footnotetext{
55 Parte das ideias que se apresentam neste item foram publicadas por nós na Revista Estudos Semióticos, v. 15 (2), 2019, em artigo intitulado Considerações semióticas sobre o uso da tecnologia digital em sala de aula.

${ }^{56}$ Nossas observações sobre ensino escolar se dão, em sua maior parte, empiricamente em escolas particulares da região metropolitana de São Paulo, e por meio de observação das experiências propostas por professores nos planos de aula disponibilizados no Portal do Professor do MEC, http://portaldoprofessor.mec.gov.br, além de reportagens e artigos colhidos na mídia.
} 
a consulta a bibliotecas, a dicionários em formato de livros e a convivência de corpos em um mesmo espaço. O espaço escolar, que constitui um espaço primordial de socialização de nossa sociedade contemporânea, concorre com o espaço digital de convivência que os alunos frequentam por meio de aplicativos de bate papo individual ou em grupo, redes sociais nas quais se encontram grupos privados ou públicos etc.

A chegada da tecnologia digital às salas de aula configura-se, a nosso ver, como esse momento de embate entre o velho e o novo do mundo, como colocado por Hannah Arendt (2014). À escola, e aos educadores, cabe mediar esse embate, apresentando o velho mundo à nova geração e cuidando da nova geração para que ela possa não apenas conhecer o mundo que habita, mas também fazer dele o melhor uso. Com base no que nos é trazido por Haroche (2005), consideramos que a tecnologia é responsável por trazer para a esfera escolar os problemas que a socióloga francesa aponta como responsáveis pela crise da transmissão do saber: a aceleração do tempo, pela rapidez do acesso às informações que lhe é característica; a primazia das informações não cumulativas, abundantes, que, adicionamos, nem sempre têm origem em fontes identificadas ou confiáveis; o desprezo pela sabedoria, fruto da reflexão e da lentidão do pensamento; e o alto número de fontes de informação disponíveis na internet, em geral pouco qualificadas. Além disso, cabe lembrar o excessivo conteúdo escolar que se observa nos currículos brasileiros, o que dificulta, ou mesmo impede, o aprofundamento da reflexão.

\subsubsection{Prescrição dos documentos legais}

É oportuno relembrar, neste ponto, que os documentos oficiais que estabelecem diretrizes para a educação no Brasil concebidos após a Constituição de 1988 prescrevem que se faça uso das tecnologias digitais em sala de aula. Os Parâmetros Curriculares Nacionais, PCN, de 1998, pedem que se desenvolvam trabalhos que "contemplem o uso das tecnologias da comunicação e da informação, para que todos, alunos e professores, possam delas se apropriar e participar, bem como criticá-las e delas usufruir" (BRASIL, 1998a: 11), e a Base Nacional Comum Curricular, BNCC (BRASIL, 2017: 9) indica, dentre as competências que o 
aluno deve adquirir durante a sua vida escolar, que o aluno deve, "de forma crítica, significativa, reflexiva e ética", "compreender, utilizar e criar tecnologias digitais de informação e comunicação", para que isso possa levá-lo não só a se comunicar, mas também a "resolver problemas e exercer protagonismo e autoria" em contextos individuais e comunitários.

Ao se comparar a BNCC com os PCN, nota-se um acréscimo significativo no tocante ao modo como o aluno deve se relacionar com as tecnologias, o que reflete as mudanças no papel cada vez mais central que ela desempenha na sociedade. Ainda em se tratando da Base (BRASIL, 2017: 61), adiciona-se a importância de que a escola "eduque para usos mais democráticos da tecnologia e para uma participação mais consciente da cultura digital" (grifos nossos). Tanto a solicitação por um uso mais democrático quanto a por uma interação mais consciente levam a uma problematização do uso das tecnologias digitais e da busca e utilização de informações encontradas na internet.

\subsubsection{Uso da tecnologia nos planos de aula analisados}

Ao se observar o que é feito em sala de aula por meio da leitura e da análise de planos de aula feitos por professores e disponibilizados online, percebe-se que a tecnologia penetrava, no período dos planos analisados, a sala de aula como um suporte de informações que não estava sendo suficientemente problematizado. Dentre os planos de aula que analisamos no capítulo 3, temos, por exemplo, uma aula sobre interpretação de tirinhas que deve ser dada no laboratório de informática, porque estão indicados os endereços da internet onde elas se encontram - buscar as tirinhas nos sites consiste no "uso da tecnologia" proposto no plano 03. O plano de aula 01 propõe uma visita virtual ao Museu de Língua Portuguesa na qual o uso da internet é muito bem explorado com uma proposição do acesso dos alunos ao site do museu para se realizar uma navegação pelo site e se fazer uma busca de informações para responder a perguntas propostas. $\mathrm{O}$ acesso dos alunos à internet limita-se, porém, ao site do Museu, e não cabem aí questionamentos sobre quem colocou essas informações lá ou o quanto se pode confiar nelas. O plano 04 propõe uma aula sobre a poesia de Cecília 
Meireles, na qual os alunos, depois de conhecerem seus poemas, farão a composição de um poema próprio e o publicarão, por escrito e gravado em voz (há as explicações necessárias para se fazer isso), em um blog na internet. Esse tipo de aula era suficiente para familiarizar os alunos com os usos da tecnologia na época em que foram publicados os planos (entre 2009 e 2012), mas são insuficientes para o tempo atual (2020), pois não se faz questionamentos sobre fontes, origens, elaboração das informações ou como se estabelecem diálogos entre o texto que se tem e outros. De fato, não foi encontrado nos planos que olhamos e que analisamos nenhuma menção ao questionamento sobre, por exemplo, responsabilidade das fontes.

Essa ausência de questionamento pode certamente ser atribuída ao fato de que, no início do uso da internet em sala de aula, ainda havia pouca preocupação com o excesso de informações e não se pensava nos problemas causados pela propagação de notícias falsas e de fontes não legítimas, o que hoje vem crescentemente constituindo grande preocupação não apenas para a escola, mas para toda a sociedade. O que se observou nos planos analisados foi que sua maior preocupação residia em familiarizar professores e alunos com o uso da tecnologia.

\subsection{Princípios semióticos aplicados à esfera educacional}

Se as condições do mundo contemporâneo não favorecem a aprendizagem da profundidade do pensar (conforme Haroche (2005) e outros autores contemporâneos), faz-se premente a busca por princípios teóricos que ajudem a lidar com essa nova realidade, jogando luz sobre seus pontos mais estratégicos e possibilitando que sejam vislumbrados caminhos novos e mais adequados. Ao cenário de instabilidade do saber acrescenta-se a instabilidade sobre as fontes do saber, outrora mais limitadas, porque se restringiam ao que se alcançava fisicamente, e que atualmente se encontram em número muito grande, virtualmente infinitas, pois ao estarem disponíveis digitalmente, fazem parecer não haver limites para encontrá-las ou alcançá-las. 


\subsubsection{Para se pensar o uso da tecnologia em sala de aula}

Por meio dos conceitos e métodos de análise da semiótica greimasiana, é possível buscar a maneira como se atribui sentido às coisas do mundo pela observação de como se organizam suas relações. Para essa investigação, observam-se os elementos que se colocam no mundo tanto online quanto offline, situados no tempo e no espaço e que envolvem sujeitos ou atores, visando a convocar princípios que possam auxiliar no que se intitula letramento digital, ou seja, a competência de um sujeito de saber compreender e utilizar-se dos recursos digitais.

\section{O sujeito da falta ou do excesso}

Partindo do princípio de análise semiótica do sujeito da falta, um sujeito que está sempre em busca de um objeto com o qual estabelecerá uma junção, coloca-se, para a problemática que analisamos, um sujeito que busca entrar em conjunção com um saber (ou em disjunção com uma ignorância, um não-saber). No caso da escola, esse sujeito é actorializado como um aluno que busca informações, fatos, opiniões que possam compor seu conhecimento sobre algum assunto ou domínio do saber. Antes da existência acessível do mundo digital e suas inúmeras fontes de informação, de fatos e de opiniões, as fontes de saber desse sujeito eram mais restritas: os professores, a biblioteca da escola, os livros escolares, as enciclopédias, os jornais impressos. Atualmente, elas se multiplicaram a ponto de algumas não serem conhecidas ou não poderem ser recomendadas por aqueles que são, em princípio, os sujeitos do fazer-saber: o sujeito que irá fazer o outro sujeito entrar em conjunção com o seu objeto valor, ou seja, o professor, que é o destinador que atuará sobre o destinatário aluno. Coloca-se, assim, em contraponto ao sujeito da falta, o sujeito do excesso, que busca entrar em disjunção com o excesso de informações a que está submetido. Livrar-se desse excesso e reter apenas o que lhe é importante é, também, entrar em conjunção com o saber. 
Pensamos que, para satisfazer o que pede a Base Comum Curricular Nacional em relação ao uso crítico, significativo, reflexivo e ético das tecnologias digitais, elas precisam ser tratadas como um conteúdo, no sentido pedagógico dessa palavra: definir o que é, como e quando utilizar, como procurar informações e como verificar sua veracidade, por exemplo ${ }^{57}$. Cabe ressaltar que o que se entende por conteúdo é o conjunto de saberes que se ensina e, na BNCC, o conteúdo visa a construir as habilidades e competências do estudante. Tanto a Constituição Brasileira (1988) quanto a Lei de Diretrizes e Bases da Educação Nacional (LDB 1996) já colocam a necessidade de se fixar conteúdos mínimos que assegurem a formação básica comum e o respeito aos valores culturais e artísticos. Ao pensarmos o uso da tecnologia como um conteúdo, queremos também dizer que ela contribui, de modo direto e decisivo, para a formação do estudante ${ }^{58}$.

\section{Em busca das fontes do saber}

Uma primeira proposta que se coloca refere-se à necessidade de, além de a escola indicar "leia este livro e não aquele", "considere preferencialmente estes autores para estes assuntos", que ela também aponte a necessidade de se buscar quem são os autores e responsáveis por uma informação publicada ou por um site de informações que propaga notícias, buscar quais os grupos de pessoas que produzem conteúdo confiável e ensinar que não se pode confiar na primeira informação que aparece em um site de pesquisa. Supondo que a biblioteca física da escola contenha os livros e materiais que ela considera dignos de confiança, pergunta-se se em seu site, para os alunos, ela possui também uma lista de indicações de fontes confiáveis para pesquisa. Essas fontes seriam, entre outras, sites de jornais, de conteúdo online, canais no YouTube de jornalistas, historiadores, professores que

\footnotetext{
57 Nos PCN, os conteúdos são "meios para que os alunos desenvolvam as capacidades que lhes permitam produzir bens culturais, sociais e econômicos e deles usufruir" (BRASIL, 1998a: 74).

58 "Trabalhar alguma coisa como um conteúdo" nos ocorre também pela experiência que tivemos em um colégio paulistano no qual se buscava ensinar, por exemplo, o trabalho em grupo como um conteúdo, no sentido de que era necessário, antes de se propor trabalhos em grupo, que os alunos soubessem o que era e como se organizar para isso: desde escolher os pares, arrastar as cadeiras, juntar-se, até quem lidera a discussão, quem cronometra o tempo que se tem, quem escreve, quem apresenta o trabalho para os colegas se for o caso etc.
} 
sejam reconhecidos por seu trabalho sério pela comunidade competente e seu comprometimento com as informações que disseminam. A escola ensina a questionar se as informações disponíveis são originais, a que tempo pertencem ou se podem ter sido adulteradas por alguém que não seus autores?

Ademais, não se pode esperar que a construção do saber, feita pelo aluno, se dê apenas em relação às fontes indicadas pela escola, uma vez que essas fontes se multiplicam a todo momento e em grande velocidade, além de também desaparecerem ou deixarem de ser atualizadas sem aviso prévio. A grandiosidade do volume de informações disponível na internet e a velocidade com que uns surgem e outros desaparecem dificultam o questionamento, pois o grande número de opções confunde e ilude, fazendo com que o sujeito se creia bem informado, frente a um mar de opções que se mostra, em sua maior parte, pouco qualificado. Por isso, faz-se necessário ensinar os sujeitos em busca do saber a como construírem seus percursos. O papel da escola é guiá-los por esses caminhos, de modo semelhante ao que faz quando indica livros ou autores nos quais se pode confiar.

\section{Estabelecimento do contrato de fidúcia}

Desse modo, colocam-se em questão os termos de confiança, ou seja, com qual sujeito se pode estabelecer um contrato fiduciário, pressuposto imprescindível de toda comunicação. O contrato fiduciário põe em jogo um fazer persuasivo, correspondente à manipulação, por parte do destinador, e um fazer interpretativo, correspondente à sanção, por parte do destinatário. Os dois fazeres estão ligados à instância da enunciação e consistem na convocação de modalidades, pelo enunciador, com vistas a fazer aceitar, pelo enunciatário, o contrato enunciativo proposto e, da parte do enunciatário, com vistas a crer na proposta que Ihe é colocada (GREIMAS e COURTÉS, s/d [1979]). A relação fiduciária se coloca entre os planos do ser e do parecer, estabelecendo, assim, a veridicção do discurso - se o enunciatário não reconhece como verdadeiro o que é colocado pelo enunciador, a relação comunicativa não se estabelece. Entram em jogo, nesse momento, o crer-verdadeiro, que precede o saberverdadeiro, numa questão atual cuja reflexão em semiótica remonta ao trabalho de Greimas 
(2014: 131, publicação original em 1983) que nos traz que o reconhecimento da "verdade" situa-se mais próximo do que se adequa ao universo cognitivo do destinatário do que daquilo que se adequa à "realidade" referencial. Ressalte-se que se fala de re-conhecimento, especificado como uma operação de comparação entre o que se propõe e aquilo que já se conhece ou em que já se crê. Passa-se, portanto, a pensar que a construção da verdade no interior do discurso é feita por meio desse reconhecimento, fazer interpretativo do destinatário, realizado por meio do estabelecimento de interdefinições, interrelações de um universo que lhe é próprio, ou seja, ela vem a ser o produto de uma semiose.

O estabelecimento dessas interdefinições, entretanto, exigiria um árduo trabalho de pensamento e reflexão, dificultado e, em grande parte das vezes, mesmo impossibilitado, pelo volume e por como se dá a circulação das informações, entre outras coisas. Por isso, o regime de estabelecimento da verdade discursiva acaba assentando-se mais sobre o crer - que se apoia sobre uma base fiduciária - do que sobre o saber - cuja existência repousa sobre uma base lógica (GREIMAS, 2014). O saber exige um estabelecimento lógico de uma rede de conceitos a fim de constituir uma "verdade", enquanto o crer consiste em se assumir uma rede que já tenha sido estabelecida (de modo bastante mal feito, muitas vezes) por outro grupo no qual se confia. Em ambos os casos, tem-se como "verdade" a relação entre o que foi produzido pelo discurso e os valores que nele circulam. Chamamos de rede mal estabelecida aquela que, visando a ser facilmente aceita pelos seus destinatários, se constrói sobre dualidades simplistas e situadas nos extremos, que não admitem meios termos ou discussão: nela as coisas "são" ou "não são". Isso é curioso porque, em língua portuguesa, as coisas podem ser, mas podem também apenas estar, o que coloca aos seus falantes mais familiaridade com operações graduais em vez de absolutas, entre um caráter mais provisório e um caráter mais permanente, que muitas outras línguas não têm em seu sistema verbal e semântico. Teoricamente, por causa dessa diferença de linguagem, deveríamos os lusófonos ter maior facilidade de abertura aos estados de transformação e ao que se estabelece como mais provisório ou mais permanente, distinguindo-os ${ }^{59}$. Essa construção das relações em campos tanto mais permanentes (do ser) quanto mais provisórios (do estar) tende a

\footnotetext{
${ }^{59}$ E penso que temos, mas que, para este momento, isso esteja suspenso, encoberto pelo discurso de ódio e de intolerância que se nos tem sido imposto com força violenta.
} 
possibilitar uma abertura maior em relação à relativização do conceito de verdade no universo cognitivo, o que favoreceria a construção de um universo de veridicção comum pelo movimento do sujeito em relação ao outro, em um ajustamento de percepções que tenderiam a encontrar-se em um ou mais pontos que, nem para o lado de um, nem para o do outro, seriam aceitos como "suficientemente verdadeiros" para ambos. Greimas (2014: 138-9) aventa essa possibilidade ao trazer que, para além do binarismo, se proponha o quadrado semiótico, que, mesmo conservando uma estrutura binária, admite termos neutros e complexos, que operam concessivamente [e...e] de modo que seja possível abarcar não apenas os discursos científicos (mais categóricos), mas também os de arte e religião (mais graduais).

\section{Entre o crer e o saber, o conceito de veridicção}

Em relação ao estabelecimento do conceito de verdade, são trazidas para esta reflexão as bases epistemológicas da semiótica greimasiana de que a "verdade" coloca-se como um parecer ser, construído internamente no texto pela coerência de seus conceitos, em contraste com outras teorias que concebem um referente "real" no mundo cuja representação deve ser dada por meio do discurso. A "verdade" coloca-se, desse modo, como imanente ao texto, como uma construção que se apoia entre aquilo que é e aquilo que parece ser. Por seu lado, a comunicação, como processo entendido semioticamente, incide mais sobre o fazer crer do que, como muitos supõem, sobre um fazer saber (GREIMAS, 2014), visto que os sujeitos envolvidos nessa relação já foram previamente modalizados e afetados por outros textos, outros creres e saberes anteriores que Ihes constituem. Para Greimas (idem) a relação entre o crer e o saber se articula sob muitas nuances, visto que eles muitas vezes se assemelham (quando relaxados), outras vezes se opõem (quando tensionados). Pertencentes a um mesmo universo cognitivo, eles, porém, operam sob tensões, dando lugar a articulações ora lógicas, ora fiduciárias.

Para Lopes e Beividas (2009: 446), a semiótica, ao olhar para a comunicação, entende que "sem garantias de uma verdade intrínseca do mundo, nosso pouco de saber sobre o 
mundo está plenamente invadido pelo nosso crer nos outros". Os semioticistas também nos trazem o conceito de que a persuasão, fim último da comunicação e definida nesse artigo gradualmente como uma intersecção entre a demonstração e a argumentação, traduz-se pela diminuição do saber acoplada a um aumento do crer. Ora, em tempos de pós-verdade e da complexidade do discurso na internet (BARROS, 2015), esse parecer tem sido instado ao modo dominante de se proceder. Trata-se da base sobre a qual atualmente circulam informações e notícias abundantemente, o que reitera a importância da formação, pensada neste texto como acontecendo por meio da escola, de sujeitos que enxerguem essas astúcias e malícias do texto, para que possam se tornar competentes para além de suas crenças, no estabelecimento de suas verdades, ou, também, que tenham competência para reconstruir a coerência de um texto, tanto interna quanto externa, a fim de identificar se as informações fazem sentido60. Além disso, ao propor fontes dignas de credibilidade, a escola ensina também em quais sujeitos se pode crer, o que também se coloca como sendo de crucial importância.

Ainda, no entanto, vale lembrar que a persuasão é, segundo Arendt (2014), condição de comunicação democrática, que se dá entre iguais. Para a situação de sala de aula, a relação desigual entre o sujeito que ensina e o sujeito que aprende demanda autoridade e confiança, construídas sobre relações pautadas por um crer no saber daquele que se encontra investido pela autoridade para ensinar. Daí uma diferença importante entre o discurso na internet e o discurso na sala de aula que não tem sido suficientemente considerada e que gera como consequência algo de confuso entre o funcionamento dessas duas esferas.

\subsubsection{Para se pensar o discurso na internet}

\footnotetext{
${ }^{60} \mathrm{~A}$ respeito de modos de construção de uma leitura mais coerente por parte dos alunos no contexto escolar, recomendamos a leitura do artigo de Shimoda e Ferreira (2019) "O ensino da coerência textual em enunciados verbais e não-verbais: uma abordagem alternativa" e também a conferência de Karla de Araújo Faria para Ciclo de Entrevistas Educação e Semiótica, da UFRJ, disponível em https://youtu.be/4-X2/lul9nE (acesso em setembro de 2020).
} 
Em se tratando da circulação de textos nesse novo mundo digital que se coloca como fonte de conhecimento e suporte de circulação do saber, recorremos aos estudos de Diana Barros sobre o discurso na internet (2015) para caracterizá-lo e mais bem compreendê-lo no que se aplica a seu uso na esfera educacional. Partindo do conceito de enunciação, central em sua análise (conforme Teixeira, 2020), Diana Barros (2015) aponta quatro aspectos principais a serem considerados a respeito do discurso na internet: definições a respeito das diferenças entre fala e escrita; seus efeitos de sentido na interação entre os sujeitos; a organização enunciativa e veridictória dos discursos na internet, donde decorrem as especificidades de autoria e anonimato; e o caráter público e privado desses discursos.

Ao apontar para as características de distinção entre fala e escrita, Barros (2015) nos mostra que em muitos casos não é possível distinguir-se completamente uma da outra e que o discurso na internet se coloca como lugar privilegiado de observação dessas posições intermediárias entre fala e escrita. Em relação aos aspectos temporais, a fala apresenta-se como concomitante ao tempo de elaboração e a escrita, como não-concomitante. Assim, a escrita mostra-se planejada e a fala, espontânea. Para o mundo digital, tem-se por exemplo os sites de bate-papo ou aplicativos de mensagens que, embora escritos, trazem mais acentuadamente as características da fala: não planejada, com marcas de reformulação e fragmentação, o que provoca efeito de informalidade e incompletude. Isso pode ser valorizado positiva ou negativamente. Para Barros, os discursos da internet trazem os atributos da fala e da escrita com as valorações positivas e negativas de ambos. Em relação ao espaço, a fala produz o sentido de presença e a escrita, o de ausência. Em situação ideal de fala e escrita, esta distancia e aquela aproxima, e os efeitos tanto podem ser positivos, como cumplicidade e envolvimento, no caso da fala, e objetividade e racionalidade, no caso da escrita, como negativos, como excesso de intimidade e falta de objetividade, e ausência de cumplicidade e de envolvimento, respectivamente, conforme Barros (idem). Para os atores, em situação ideal, a fala constrói o sentido de realização coletiva e a escrita, individual. Temse para aquela um sentido de descontração e cumplicidade e, para esta, de formalidade e assimetria. Novamente, os efeitos podem ser valorizados positiva ou negativamente. Apontam-se, assim, as características que permitem identificar fala e escrita e, a partir delas, o discurso na internet, tendo por base pessoa, espaço e tempo enunciativos. 
Quando se aplicam tais valores para o discurso na internet, verifica-se que muitas das características da fala estão presentes em contexto escrito, e vice versa. Desse modo, Barros (2015) caracteriza o discurso da internet como complexo: ao mesmo tempo próximo e distante, descontraído e formal, incompleto e completo, objetivo e subjetivo. Ao apresentarse como caracterizado por termos complexos, esse discurso precisa ser entendido como sendo de conjunção concessiva entre contrários: fala, embora escrita ou escrita, embora fala. Como resultado, observa-se a exacerbação dos sentidos, por englobar as interações tanto da modalidade escrita quanto falada, que resultam da interatividade intensa, longa conservação do conteúdo e grande extensão de seu alcance.

Quanto à veridicção, essas relações entre o ser e o parecer adquirem características próprias na internet. Barros (2015) nos aponta que, a priori, os discursos na internet são tomados como verdadeiros (aquele que parece e é), segundo a semioticista, e, mais do que isso, como discursos que desmascaram a mentira (que parece, mas não é) e revelam o segredo (que é, mas não parece). A assunção do discurso da internet como verdadeiro, o desmascaramento da mentira e a revelação do segredo decorrem do efeito de sentido da grande quantidade de saber acumulado e da interatividade acentuada (ibid.: 22). Essa última característica também leva o destinatário a julgar-se co-autor do discurso.

A partir do exame dos procedimentos sintáticos e semânticos da enunciação no discurso da internet, Barros (2015) ressalta a característica do anonimato, que se situa dentro da questão de autoria, relacionada à organização da enunciação do discurso. Essa organização é feita por meio de dois caminhos: o sintático-narrativo e o semântico, cuja combinação produz um efeito de sentido. Por meio do estudo da sintaxe do discurso, depreendem-se as relações que se estabelecem entre enunciador e enunciatário (que, juntos, constituem o sujeito da enunciação) e que produzem dois efeitos: o de aproximação da instância da enunciação, com o uso de eu-aqui-agora no discurso (denominada debreagem enunciativa) e o de distanciamento da instância da enunciação, feito por meio do uso de um ele-lá-então (ou debreagem enunciva). Barros nos explica que, no discurso na internet, predominam as debreagens enunciativas que, por princípio, deveriam produzir o efeito de autoria. Ocorre, porém, que, para se ter autoria, é necessário que se tenha um investimento figurativo no nível semântico do discurso, com a identificação de um ator que figuraria como "autor" do discurso 
(explicam-se as aspas pelo fato de a semiótica não considerar o "autor" de carne e osso, mas sim sua projeção no texto por meio do enunciador). O ator da enunciação tem um corpo, formado pela totalidade enunciativa construída, no qual se mostram as marcas de sua inserção histórica, social e ideológica. Ainda, é necessário distinguir o ator da enunciação, cujo corpo se constitui por uma totalidade, do ator da narração, definido por um único discurso. É nesse ponto que Barros aponta o descompasso entre a sintaxe e a semântica do nível discursivo no discurso na internet que permite a construção do anonimato (2015: 2425):

[...] no caso da internet, os recursos semânticos, principalmente o da figurativização do ator da enunciação, parecem caminhar na direção contrária da que tomam os procedimentos sintáticos. Se, nos discursos na internet, os procedimentos sintáticos criam a ilusão de aproximação e subjetividade, na semântica discursiva, os temas são, em geral, figurativizados com o recurso principal dos pseudônimos, mas nem sempre ocorre a figurativização exacerbada ou iconização com o nome próprio e outras formas de concretização, o que conduziria à formação de totalidades discursivas e à construção plena do ator da enunciação. Disso decorre o anonimato, que permite a construção do sujeito da enunciação e, até mesmo, do ator-narrador, que é uma voz delegada pelo enunciador, mas não a do ator da enunciação pleno. Resulta daí o efeito de sentido de irresponsabilidade, moralizada negativamente pela sociedade. (negrito no original)

O anonimato também se relaciona à distinção entre público e privado. A semioticista explica que tudo leva a crer que o discurso da internet também se define pelo complexo público e privado, com a ruptura dessa oposição. Se o domínio público se regula por leis e regras e o privado por preferências pessoais, na internet é possível exporem-se preferências pessoais ao público, e até mesmo fazer-se delas regras. É também possível que um sujeito se coloque como pessoa pública anonimamente, ou protegido por um pseudônimo, constituindo-se como uma não-pessoa, e que, a partir desse não-lugar de sujeito, possa intensificar a interatividade com outros sujeitos, alargando o alcance de sua comunicação. A condição de não responsável pelo que enuncia dá ao sujeito um poder que lhe permite mentir, difamar, incitar a violência. Tais características levam a internet a configurar-se como o lugar do discurso exacerbado (BARROS, 2015). 
Essa exacerbação do discurso é fortemente persuasiva, o que significa que se apoia de modo tônico no crer e de modo átono no saber. Assim, a manipulação do enunciatário pelo enunciador é feita mais fortemente pelo sujeito intolerante, porque exacerbado, do que pelo sujeito moderado e reflexivo, que tende a ter uma "voz" menos intensa e, nesse cenário, menos atraente. O discurso exacerbado é não dialógico, homogêneo, discurso da verdade única e incontestável (BARROS, 2016), e, acrescentamos, apresenta-se também como resultante do tratamento veloz das informações apressadamente encontradas e prontamente utilizadas e replicadas e da não disposição dos sujeitos para a problematização e o diálogo. Pode-se dizer ainda que o discurso exacerbado é produto direto da crise da transmissão do saber contemporânea, como indicado por Claudine Haroche (2005), pelo individualismo e o imediatismo de seu caráter.

Desse modo, o discurso exacerbado da internet costuma ter como alvo mais fácil o sujeito ingênuo ou o fanático, conforme definidos por Dilson Cruz (2008), ambos apoiados em muito crer e pouco saber, com a diferença de que, para o ingênuo, a crença é átona, para que possa relacionar-se com uma extensa gama de objetos de saber e, para o fanático, a crença é tônica e exclusivista. O aluno, como sujeito em busca de informação para a construção de sua competência, encaixa-se frequentemente nesse perfil de sujeito ingênuo, caracterizando-se assim também devido a sua relação com muitos objetos de saber (crença átona) e o andamento rápido de sua relação com esses objetos. Como explicam Lopes e Beividas (2009), o crer convoca o tímico e, por isso, provoca forte adesão apaixonada, que tende a fechar o sujeito para outros percursos de busca do saber, limitando-o ao universo desses discursos exacerbados que, muitas vezes, mostram-se descompromissados com a verdade factual.

Esse discurso tônico e assentado no crer apresentado pela internet contrasta com um discurso mais átono que se encontra na escola, assentado sobre o saber, atonia que se apresenta como característica do ator da enunciação dos planos de aula estudados (no capítulo 3). Some-se a isso a destituição do professor do lugar de autoridade do saber, conforme já discutimos anteriormente, e tem-se a escola caracterizada como um lugar cujos valores colocam-se como menos atraentes para os alunos, e para a sociedade em geral. Como resultado, essa sociedade chega a crer poder prescindir do saber escolar porque a internet lhe proveria o saber necessário de modo mais atraente. Por esse motivo, faz-se necessária a 
reflexão sobre as tecnologias digitais feita com base no conceito de contrato de veridicção e no conceito semiótico de estabelecimento da verdade, assentados sobre a inter-relação e as intersecções entre os universos discursivos presentes no mundo online. Essa reflexão precisa estar sob a atenção que se deve ter quando se está no campo da manipulação persuasiva exercida pelos sujeitos destinadores exacerbados, que com suas vozes fortemente marcadas promovem "verdades" fáceis e monológicas, frente às quais os sujeitos destinatários se quedam ingênuos e são instados a "crer" enquanto acreditam que possuem um "saber".

\subsection{Considerações sobre o uso da internet na educação}

Voltemos à colocação trazida pela BNCC (BRASIL, 2017: 61), preconizando que a escola "eduque para usos mais democráticos da tecnologia e para uma participação mais consciente da cultura digital" (grifos nossos). A BNCC está trazendo para a cena educativa a tecnologia como instrumento da democracia, e a cultura digital como parte da vida do estudante. Se antes se concebia a tecnologia digital como uma ferramenta, um suporte não suficientemente problematizado e não muito diferenciado do que se tem no mundo físico (pensemos nos tablets que entraram no lugar dos livros com a diferença apenas do suporte), atualmente é necessário ir além disso e configurá-la como parte integrante da escola. Mais ainda, no momento presente, por causa da pandemia de Covid-19 que se vive em 2020, os meios digitais no ensino assumiram um papel de grande protagonismo em educação (em se pensando na parcela da população que tem pleno acesso a ele, claro). Até o momento anterior ao início da pandemia, as questões do uso de tecnologia na escola se colocavam como uma necessidade de maior reflexão sobre quais poderiam ser as consequências do acesso dos estudantes a uma fonte virtualmente inesgotável, agravado pelo fato de que, atualmente, ainda não se tem experiência suficiente com o modo como esses usos estavam acontecendo no âmbito da educação escolar. Essas questões permanecem, acrescidas de outras decorrentes do fato de a tecnologia ter se tornado o meio principal de transmissão de saber e de o professor, agente 
da construção do conhecimento, e a escola, local onde esse e outros processos ligados à educação acontecem, estarem temporariamente inacessíveis presencialmente.

Sobre o acesso dos estudantes à internet, como se podem definir cuidados a serem tomados para que estejam atentos ao acento que se coloca sobre o regime do crer no fazer interpretativo? O fazer persuasivo do discurso na internet se apoia muito fortemente sobre essa característica, e muitos produtores do discurso online são mestres na construção desse tipo de persuasão. Ao estarem atentos para essas questões, espera-se que os estudantes possam buscar se tornar sujeitos menos ingênuos e mais perspicazes, sujeitos competentes na busca pelo saber. Percorre essas indagações nossa tentativa de entendimento sobre o que significa participação mais consciente da cultura digital, solicitada pela BNCC. Consciência, nesse contexto, se traduz como crítica, como um fazer refletido e pensado. Quando se alia a palavra tecnologia à palavra democracia, como se vê nesse documento que pede que seu uso seja mais democrático, dentre outras questões, coloca-se que o acesso a ela deve ser ampliado e que ela deve ser usada de forma mais igualitária, livre e em benefício de todos. Faz sentido, nesse contexto, que se pense em letramento digital como sendo a competência de se utilizar diferentes recursos digitais do modo mais adequado às finalidades que se buscam e também como um modo de saber ler e atribuir significado às informações encontradas pelos caminhos digitais.

Nessa nova realidade de uso das tecnologias, muitas escolas procuram conciliar em seu espaço e nas aulas os aparelhos digitais e os conteúdos que eles permitem acessar ou, também, fazem a inclusão de conteúdos digitais nas tarefas, como uma busca auxiliar por informações. A busca de informações online, no entanto, traz uma complexidade que nem sempre é levada em conta. Considere-se que, para as gerações nascidas até os anos 1990 e que viram o advento da internet, há uma correspondência mais facilmente apreensível entre o mundo offline e o mundo online do que para aqueles que não tiveram esse referencial. Essa correspondência facilita a tarefa de se perceber a organização das informações disponíveis e remete à reflexão arendtiana sobre a necessidade de apresentação do mundo velho para a nova geração que nele se forma (ARENDT, 2014).

Tomemos, assim, os jornais, fontes de notícias durante um século, ou pouco mais que isso, que têm rumado para seu desaparecimento físico para existirem apenas digitalmente. 
Para aqueles que só conhecem jornais digitais, torna-se mais difícil estabelecer a diferença entre notícias postadas por um portal de jornalismo e por um blog. Em se pensando que muitos sujeitos consomem notícias a partir de redes sociais, não nos parece ser evidente ou intuitiva a distinção entre um perfil de um jornal e um perfil qualquer, embora os perfis verificados, como se encontram na rede Twitter, já ajudem nesse sentido. Nossa hipótese é a de que aqueles que conhecem o jornal físico conseguem conceber mais concretamente uma totalidade submetida a uma organização que tem responsabilidade sobre as informações que veicula. Como consequência, reconhecem mais facilmente que as informações vindas daí seriam, em tese, mais confiáveis.

Para as gerações que não têm familiaridade com um jornal que circula no meio físico, no entanto, essa relação entre o que existe no mundo digital e no mundo real não se coloca de forma tão perceptível, porque alguns limites vão-se atenuando e, possivelmente, se esvaindo. Pensemos, assim, que um jornal, para essa nova geração, parece não ser percebido de modo separado de um portal de notícias ou de postagens de notícias feitas pelo perfil de um blog, um jornalista ou o de uma pessoa qualquer em redes sociais. Pode-se mesmo pensar na existência de uma gradação de fontes de informação que vão da mais confiável à desconhecida e, consequentemente, menos confiável. Desse modo, quando os professores e a escola apresentam o mundo online em sala de aula, seria importante ter em mente que se está lidando com uma geração que tem muito menos, se tiver, referências em termos do funcionamento da obtenção de informação do mundo material, dos caminhos que aquela informação percorre, de onde ela se situa ou de quem se responsabiliza por ela. É provável que se tiverem a possibilidade de enxergar uma organização da circulação das informações anterior ao mundo digital com o qual estão familiarizados, os alunos terão maior capacidade de estabelecer uma correspondência entre a circulação do mundo digital e a do mundo material, organizando melhor essas informações e acrescentando significado ao que eles conhecem. Enxergar o modo material, físico, lugar de circulação das informações lhes possibilita vê-las de modo um pouco mais palpável. Encaixa-se nessa descrição do reconhecimento das melhores fontes de informação o conceito de ator da enunciação, da construção de uma identidade por meio da apreensão das recorrências que a caracterizam, em uma totalidade de discursos. Esse ator, reconhecido a partir dos traços que o identificam, 
constituiria um modo mais "seguro" de se identificar se um discurso tende a ser mais falso ou mais verdadeiro, ou a qual esfera pertence, quais os valores que veicula etc.

Em artigo no qual reflete sobre a crise de veridicção e interpretação de textos que acomete a sociedade, Regina Gomes (2019) defende que é necessário ensinar aos alunos mais criticidade na leitura, porque eles têm sido bombardeados na internet por textos que misturam regimes de crença ${ }^{61}$ e diferentes gêneros textuais, os quais, da parte do enunciador, apresentam "uma aposta na credulidade e no envolvimento afetivo do leitor, na sua adesão e identificação aos valores" (idem: 27). Para Gomes, essa criticidade está relacionada ao ensino da observação da dimensão cognitiva e à exploração de aspectos linguístico-discursivos que permitam que o prazer da leitura emerja da compreensão de seus mecanismos de construção de sentido (idem: 15), e não da simples adesão tímica do enunciatário. Cabe, assim, ao professor, segundo Gomes, propor atividades por meio das quais os alunos tomem consciência dos mecanismos discursivos empregados e possam discriminar as armadilhas e malícias dos textos. Ela ressalva também a importância de se discutir em sala de aula as formas de interação na internet, conforme apontadas também por Barros (2015): o anonimato, a falta de responsabilização pelos textos publicados e "os efeitos de um tipo de compartilhamento intenso e numeroso de informações que acaba por causar a confiança no enunciado, já que o fiador pode ser alguém da confiança do destinatário das notícias." (GOMES, 2019: 28), o que se aplica de modo mais específico ao grande problema que se coloca atualmente, o espalhamento de notícias mentirosas ou falsas, conhecidas como fake news.

Coloca-se ainda como importante refletir-se na escola sobre os aspectos público e privado da internet. Apontada como característica do discurso da internet por Barros (2015) está a ruptura dos limites entre público e privado, com a transformação desses limites em limiares e a crescente confusão que isso provoca. Trazendo essa questão para dentro da escola, recorremos novamente a Arendt que, em A Crise da Educação (2014), chama a atenção para o fato de que a oposição público e privado também é muito relevante para os sujeitos em formação. A filósofa argumenta sobre a necessidade de privacidade para constituir um lugar seguro no qual a criança possa se desenvolver. O "clarão implacável do mundo público"

\footnotetext{
${ }^{61}$ Conforme Eric Landowski (in A sociedade refletida. São Paulo: EDUC, Pontes: 1992), são dois os regimes do crer: a crença (no dito) e a confiança (no sujeito) (apud GOMES, 2019: 19).
} 
(ARENDT, 2014: 236) se opõe à segurança da escuridão que todo ser vivo precisa para crescer. Ora, a exposição da criança nas redes a retira das quatro paredes da vida familiar privada necessária para proteger a criança do mundo e também dos muros da escola dentro dos quais, supervisionada, a criança também se encontra protegida.

Isto é verdade não somente para a vida da infância, mas para a vida humana em geral. Toda vez que esta é permanentemente exposta ao mundo sem a proteção da intimidade e da segurança, sua qualidade vital é destruída. (ARENDT, 2014: 236)

Arendt ilustra essa sua tese com o exemplo de filhos de pais famosos que, com frequência "não dão em boa coisa" (ibid.: idem). Nesse ponto, pensa-se que cabe à escola (e também à família, quando possível) assumir a responsabilidade de proteger o aluno da exposição desmesurada ao mundo digital. Trata-se de uma questão importante para a educação no mundo digital.

Desse modo, coloca-se a importância de se ter ciência que a tecnologia e a facilidade de acesso ao mundo digital e a conteúdo hipoteticamente infinito adentraram a sala de aula e a vida de todos e, neste momento, por essa ser uma realidade recente, ainda se amargam momentos difíceis para aprender a lidar com ela. Tudo isso se agrava com o fato de o ensino ter migrado abruptamente, de modo exclusivo, para o mundo online, em 2020. Ao se trazer a educação apenas para o digital, como acontece emergencialmente durante a pandemia em que nos encontramos ${ }^{62}$, apaga-se ainda mais a organização física do mundo e a interação entre as pessoas, parte do ensino sobre vida social que é dever da escola. Essa situação mostra que o ensino online é melhor do que ensino nenhum, mas não configura uma solução.

Aponta-se, ainda, como muito importante, o descompasso de percepção de vivência no mundo digital entre as diferentes gerações, com os mais jovens mostrando-se muito mais rápidos em operar os modos de acesso a esse mundo do que os mais velhos, sem que, no entanto, se perceba que essa velocidade de operação não se traduz em mais competência para lidar com o que se encontra. Pelo contrário, a ilusão de que a velocidade traga consigo competência contribui com nossa hipótese de que há dificuldade de estabelecimento de

\footnotetext{
62 No estado de São Paulo, as aulas foram suspensas em março de 2020 e em outubro houve autorização do poder público para funcionamento de atividades extracurriculares desde que não houvesse aglomeração de alunos na escola.
} 
relações de sentido para aqueles que desconhecem a organização do mundo, do tráfego de informações, dos usos da vida diária em um mundo físico, anterior à existência do mundo digital. Um dos papéis da escola é estabelecer simetrias entre o físico e o digital, entre o que é velho e o que é novo no mundo, enfim, "ordenar o mundo" (ARENDT, 2014) a fim de que o educando possa se situar. Também cabe a ela jogar luz sobre os caminhos que levam às informações para que melhor se possa escolhê-las; afinal, no mundo digital, o número de fontes e de modos como essas informações chegam até seus usuários é não só imenso, como cresce a cada dia em uma velocidade difícil (para não dizer impossível) de se acompanhar.

\subsection{Reflexões finais sobre o tema}

Os educadores, aí incluídos não apenas professores, mas também pais e outros envolvidos, tendem a esquecer que, para os alunos, o mundo online se mostra muito fragmentado e descontínuo, ao mesmo tempo em que essa descontinuidade não é claramente percebida devido ao desconhecimento do funcionamento do mundo físico apontado acima e à velocidade acelerada com que as informações, fatos e eventos surgem. E embora os limites atuais entre muitas coisas, gêneros de textos ou mídias, por exemplo, se apresentem de modo muito tênue, ainda assim é necessário buscá-los, com clareza, organização espacial, estabelecimento de relações, visando a pôr alguma ordem no caos que se mostra na totalidade, até porque essa totalidade, sendo virtualmente infinita, dificilmente pode ser apreendida. Voltamo-nos ao que Hannah Arendt (2014: 243) traz para a crise na educação, que "Para preservar o mundo contra a mortalidade de seus criadores e habitantes, ele deve ser, continuamente, posto em ordem." Trata-se de evidenciar a continuidade entre as informações e os lugares em que elas cindem, a continuidade entre o mundo físico e o mundo digital, o modo como esse mundo digital foi estabelecido a partir do físico e a organização subjacente ao que se vê e se percebe, a fim de prover aos estudantes uma visão mais abrangente, em termos sincrônicos e diacrônicos, e auxiliá-los a apreender o sentido. 
Essa questão passa também muito fortemente por enxergar o lugar e o tempo a partir dos quais se olha e se percebe o mundo, pois, ainda com base em Arendt (2014: 247), é responsabilidade dos adultos apresentar o mundo às crianças para que a nova geração possa construí-lo novamente. Se os alunos, esses sujeitos aprendizes, não sabem onde estão e não reconhecem o lugar a partir de onde olham, em oposição aos olhares de outros, que partem de outros lugares e tempos, como podem enxergar-se e enxergar o mundo com alguma clareza? Ao se colocar a diferença entre os olhares, estabelecer alguns limites (tênues, voltamos a dizer, mas muito necessários), abre-se uma possibilidade de melhor estabelecer uma ordem para o que se apresenta. O papel da escola, considerada aqui como o principal dentre os atores que são responsáveis pela educação, é dar ordem ao mundo, mostrar as delimitações para que os alunos, no lugar que ocupam de aprendizes, consigam organizar um pouco o mundo em que vivem e pensar a partir dessa ordem.

Coloca-se, então, a importância de se evidenciar a heterogeneidade do mundo, online e offline, para que, enxergando essa pluralidade, se possibilitem melhores escolhas. Essa heterogeneidade não pode ser traduzida em polos opostos, o bem e o mal, porque aí se tem uma prescrição dual e não dialógica. É preciso que se mostre que há nuances, das mais benéficas às mais prejudiciais (para o indivíduo, para a coletividade), em cada um desses muitos caminhos. As posições absolutas levam à intolerância, como vimos nos estudos de Diana Barros $(2011 ; 2015 ; 2016)$. Assim, construir nos alunos a percepção da heterogeneidade do mundo, das fontes de informação e a percepção das diferenças e (de)limitações entre as fontes do saber faz parte do chamado letramento digital, que se encontra na ordem deôntica das construções da educação escolar contemporânea. 


\section{Considerações finais}

Onde há vida, há inacabamento. (Paulo Freire in Pedagogia da Autonomia)

No início desta tese, foram colocadas duas questões de investigação. A primeira dizia respeito à organização da transmissão da cultura e da construção do conhecimento no espaço escolar brasileiro, no início do século XXI, e a segunda se propunha a investigar como a semiótica, com seu ferramental de análise, poderia contribuir para melhores usos da tecnologia em sala de aula. Estabelecendo a relação entre as duas perguntas está a constatação de que o conhecimento, dentro e fora dos muros da escola, circula, cada vez mais, pelo espaço digital, e que essa é uma mudança relativamente recente e merecedora de muita reflexão por sua dimensão e pelas consequências importantes que aporta consigo. A introdução das tecnologias digitais na educação marca uma divisão, entre um "mundo velho" - analógico, offline - e um "mundo novo" - digital e online, que precisa ser enfrentada pela escola.

A respeito da primeira questão de investigação, o que fizemos foi buscar como se planeja a educação que acontece em sala de aula, entendendo que esse planejamento nos revelaria questões do professor e da sociedade referentes à aula, ao aluno e à concepção de educação em geral. Para esse entendimento, convém lembrar que o que chamamos aqui de educação combina a transmissão de cultura e a construção do conhecimento, juntas, como um processo. Desse modo, foi possível, por meio de análises que se erigiram apoiadas sobre 
o entendimento linguístico de discurso e utilizando-nos da metodologia semiótica, identificar e jogar luz sobre algumas questões.

Vimos que o plano de aula, narrativamente, é um percurso de busca pelo saber. Mais especificamente, tem-se um sujeito que busca entrar em conjunção com seu objeto valor, que chamamos de "boa aula". Assim, procuramos no Portal, onde está nosso corpus, o conceito de "boa aula" para o MEC e, depois, por meio das análises dos planos, estabeleceu-se como o enunciador do plano de aula online a concebe. Pudemos depreender as estratégias discursivas que marcaram a relação entre enunciador e enunciatário no plano e quais efeitos de sentido elas produziram. O uso do futuro como momento de referência revelou como o plano de aula constrói-se como um simulacro da aula, e como a combinação dessa estratégia discursiva temporal com a modulação da presença do enunciador fez construir sobre essa aula um efeito de quase-certeza de sua realização. Dessa modulação da presença, verificamos no plano um ator da enunciação que se constrói concessivamente, não como um sujeito do complexo, mas como um sujeito que tende ao neutro. Assim, essa relação mostrou construirse como nem próxima nem distante, não-objetiva e não-subjetiva ao mesmo tempo, operando numa esfera que não se define entre pública ou privada. Vimos que se trata de um sujeito que visa à justa medida, sujeito da moderação e do saber que se responsabiliza pelo que fala, que usa um tom de voz baixo e tende a não polemizar. Ele se mostra discursivamente como situado na dêixis da prudência, atuando entre os regimes de interação da programação e da manipulação (cf. Landowski, 2014). Figurativizado, esse professor mostrou ser um sujeito do fazer, responsável pela aula e por fazê-la orbitar ao redor do aluno, como esperado. Nossas análises, de um modo geral, a partir das conclusões a que chegaram, jogaram luz sobre como concebem a aula e como planejam atuar nela os sujeitos que se dispuseram a compartilhar online seu planejamento. Mostrou também, a esse respeito, a concepção do MEC como aquele que aprova os planos de aula que estão publicados. Se cada parte sempre representa um pouco do todo, pode-se, então, dizer que essas características que emergiram dos planos podem também ser atribuídas aos sujeitos que povoam a esfera da educação brasileira.

Sobre a segunda questão, mostrou-se frutífera a utilização do conceito semiótico de construção do contrato de fidúcia entre enunciador e enunciatário, a partir do qual se estabelece a veridicção do texto. A partir dele, colocou-se a importância da atenção ao fazer 
persuasivo dos destinadores do discurso online que, com frequência, se apoiam desmedidamente sobre o crer, no qual o sujeito exacerbado (BARROS, 2016a), como destinador, direciona seu fazer discursivo para ser aceito pelo sujeito ingênuo ou fanático (CRUZ, 2008). Trouxemos, também, a necessidade de se realçar a continuidade entre o mundo físico e o digital para os aprendizes, aos quais caberá, com a ajuda da escola, organizar as informações para que façam sentido.

Também buscamos destacar que, embora sejam apontadas uma crise da educação (ARENDT, 2014) e uma crise da transmissão do saber no mundo contemporâneo (HAROCHE, 2005), a crise da educação brasileira opera em uma lógica implicativa e, por isso, é erroneamente chamada de crise, já que o descaso contínuo de que vem sendo objeto prevê, implicativamente, os maus resultados que ela mostra. Submetida à lógica de mercado, a educação parece ter passado a operar redutivamente como uma transação que se dá entre sujeitos que têm direitos iguais e que se finda ao ser paga. Como apregoado por Arendt (2014), a educação não se dá entre iguais, mas entre um adulto responsável e um aprendiz em formação. Ao estar submetida à lógica de mercado, ela se descaracteriza. Seria preciso que operasse sob a égide da dívida simbólica (RASTIER, 2014 e 2015) para que a educação fortalecesse os vínculos entre os membros de uma sociedade com base no tripé das relações de troca: dar, receber e reverenciar esses atos.

As análises trouxeram a necessidade da atribuição de legitimidade à figura do professor, cuja relevância precisa ser reconhecida. Seja de modo presencial ou por meio digital, não há "boa aula" sem um "bom professor", um sujeito investido de um saber e um saber fazer, competencializado, reconhecido socialmente para que possa figurar como destinador. Como consequência da valorização docente, valorizam-se também a escola e o saber. Quando pensamos na manipulação, em que um destinador precisa persuadir o destinatário do valor do valor (cf. Landowski, 2014), vimos que não é ao professor sozinho ou à escola que cabe persuadir o aluno do valor do saber, mas que essa é uma tarefa da coletividade social.

Essa sanção positiva ao professor advém de uma tríade de atores sociais, em uma direção que parte do mais próximo ao professor para o mais importante e englobante: aluno, escola, sociedade. A "boa aula", para ser reconhecida como tal, também precisa de uma 
sanção, dada pela mesma tríade. Cabe, a esse respeito, para ambos os casos, uma ressalva: a de que os critérios de julgamento dessas três instâncias são muito diferentes e têm pesos distintos. O aluno, no contexto escolar, é um sujeito que não ocupa o mesmo estatuto do sujeito professor ou dos outros dois sujeitos, porque é menor de idade e não tem condições de exercer plenamente certas funções judicativas. Seu horizonte de visão sobre o processo da aula é muito curto, comparado ao dos outros atores, em relação ao que lhe será necessário para "o bom exercício da vida", objetivo último de competencialização do sujeito pela educação. A escola, por sua vez, tem a visão de critérios técnicos que a sociedade não possui, e esta última representa interesses de sua própria continuidade e melhoramento para além do horizonte que a escola consegue ver. Daí a necessidade de se combinarem os três atores para agirem tanto em momento anterior ao processo, no reconhecimento da competência do professor e da importância da escola, quanto ao seu final, na sanção da boa aula. Ou seja, reforça-se a importância da construção social coletiva, sem a qual essas duas valorizações positivas não acontecem.

O que vimos apontando como falta de legitimidade e de valoração positiva do professor foi apontado por Hannah Arendt (2014), na década de 1950, com o aspecto da perda de sua autoridade. Trata-se de um longo processo que foi se intensificando ao longo dos anos e que se agrava ainda mais, atualmente, com a internet como meio de propagação de todo tipo de discurso. Esse processo afeta toda a sociedade e põe em xeque conquistas democráticas que já se julgavam como estabelecidas, como a educação de qualidade, essencial para a formação da sociedade a que almejamos quando, por exemplo, passa-se a dar espaço equivalente a informações sérias e a mentiras. Ao observarmos o regime de crença sobre o qual operam os discursos da internet, vemo-lo como sendo o do crer, e se por causa da velocidade das informações e da enorme quantidade delas que é produzida diariamente um sujeito não é capaz de estabelecer seu regime de saber por si mesmo, é preciso que ele se apoie sobre a confiança em outros sujeitos. Silvio Luiz Almeida, jurista e professor universitário, autor de Racismo Estrutural ${ }^{63}$, se expressa a esse respeito dizendo que "é preciso ensinar em quem confiar" (ALMEIDA, 2020). Acrescentamos, complementarmente, que também é preciso ensinar em quem não confiar e, também, falarmos sobre a

${ }^{63}$ ALMEIDA, Silvio. Racismo Estrutural. Coleção Feminismos Plurais. São Paulo: editora Pólen, 2019. 
desconfiança - competência a ser construída nos alunos e que poderia atender também pelo nome de criticidade na leitura (GOMES, 2019). Essa é uma tarefa da escola, mas a parte mais relevante dela pertence a um ator muito maior, a sociedade. É preciso desenvolver novamente as relações de confiança entre as partes que a compõem, sem as quais não se pode avançar. Dentre essas relações, de modo muito importante, estão as que pertencem à esfera escolar: o relacionamento entre a família e a escola, entre a escola e o professor e entre o professor e o aluno. Sem o estabelecimento desses contratos sociais de fidúcia, não serão possíveis não apenas a comunicação, mas tampouco os avanços sociais e democráticos.

Ainda sobre a necessidade de se resgatar um reconhecimento social para o professor, apontamos um estudo publicado em outubro de 2020, o relatório Reading between the lines (Lendo as entrelinhas, em tradução livre), da Varkey Foundation (2020). Nele se analisou o status dos professores em 35 países diferentes e se concluiu que os resultados dos estudantes em testes de conhecimentos como o PISA ${ }^{64}$ relacionam-se fortemente com o status que os professores têm no país. Esse status, segundo o relatório, está ligado à riqueza nacional, ao quanto se gasta em educação e ao gênero predominante dos professores - quanto mais feminino, menos valorizado, o que nos remete diretamente ao censo do Inep de 2017 que mostra que quase $70 \%$ dos 2,5 milhões de professores no Brasil são mulheres ${ }^{65}$. 0 status dos professores é medido, no relatório, de três modos: (i) ranking em comparação a outras profissões que requeiram mais ou menos a mesma formação, (ii) status explícito, em que se demandavam aos entrevistados asserções explícitas sobre os professores e (iii) status implícito, medido em reações espontâneas à atribuição de adjetivos positivos ou negativos aos professores. O Brasil ficou em último lugar no item (i), o que quer dizer que os brasileiros julgam que os professores, dentre as profissões semelhantes, ocupam a de mais baixo prestígio e status social. Ficou em 23 lugar no status explícito (na frente dos demais países latinoamericanos) e 25o em status implícito (atrás apenas da Colômbia e do Chile na América

\footnotetext{
64 O PISA, Programa Internacional de Avaliação de Estudantes, é um estudo comparativo internacional realizado a cada três anos pela Organização para a Cooperação e Desenvolvimento Econômico (OCDE). Ele oferece informações sobre o desempenho dos estudantes na faixa etária dos 15 anos. Os resultados do Brasil são pífios e estão estagnados desde 2009. Fonte: https://www.gov.br/inep/pt-br/areas-de-atuacao/avaliacaoe-exames-educacionais/pisa Acesso em outubro de 2020.

${ }^{65}$ Fonte: Agência EBC, disponível em http://agenciabrasil.ebc.com.br/educacao/noticia/2018-10/brasil-temmais-de-25-milhoes-de-professores Acesso em outubro de 2020.
} 
Latina). Ainda que não seja tão ruim a colocação brasileira em relação ao continente em que estamos nos modos (ii) e (iii), o resultado é o pior possível em relação ao prestígio social, item (i). Esse se figurativiza, no plano da expressão, entre outros fatores menores, nos baixos salários que os docentes recebem por seu trabalho ${ }^{66}$. Numa sociedade que opera por meio de transações econômicas em vez de por transações que visem a fortalecer a coletividade, baixos salários simbolizam baixo valor social. Esse sentimento que a sociedade tem em relação ao professor pode ser encontrado, com facilidade, explicitamente enunciado na mídia. Em uma busca rápida, encontramos texto de Cláudia Costin (2020), ex-diretora de Educação do Banco Mundial e diretora de núcleo de Políticas Educacionais na FGV, em artigo na Folha de São Paulo, em 29 de outubro de 2020, que diz o seguinte:

Essas celebrações [prêmio Educador nota 10, da Fundação Victor Civita] ganham relevância num contexto em que o professor é percebido por parcela da sociedade com certa piedade, dadas as condições desafiadoras de trabalho, mas sem respeito ou admiração profissional. Ora, aquilo de que os professores mais precisam não é pena, mas reconhecimento, inclusive salarial, e a construção de um ambiente mais propício a um trabalho educacional efetivo.

"Percebido com certa piedade", "sem respeito ou admiração profissional" e que enfrenta "condições desafiadoras de trabalho" (com esse "desafiadora" claramente trazendo uma atenuação do quadro). Como um ator figurativizado tão baixo na escala de valores que rege a sociedade conseguiria se tornar um destinador e persuadir outros atores do valor do conhecimento? Que tipo de sociedade se pode construir sem que o conhecimento seja valorizado euforicamente?

Apontou-se, ainda, nesta tese, que, com a disponibilidade de informações na internet, alterou-se o papel do professor. Além da questão da autoridade, de que já tratamos, o professor deixou de ser uma das fontes exclusivas de saber. Desse modo, um dos possíveis novos olhares que se poderia ter para com ele seria o de um destinador que atuaria sobre o excesso de informações que chegam por meio digital. Caberia ao professor ser responsável por sua triagem, algo que funcionasse como uma curadoria - alguém que, a partir do conteúdo escolhido como necessário pelas instituições responsáveis e do conhecimento que

66 Fazemos referência principalmente ao ensino fundamental e médio. 
ele ou ela tem do conteúdo e da comunidade em que se insere, indicaria os tempos de aquisição, as melhores atividades, a melhor explicação sobre esse conteúdo disponível online. Que outros papéis serão necessários, ao professor, assumir? Quais papéis abandonar? O que sabemos é que há mudanças, que é necessário se refletir sobre o papel dos docentes e que as questões referentes ao professor e ao ensino explodiram em 2020 devido à necessidade do isolamento social decorrente da pandemia de Covid-19. As escolas foram fechadas no mundo todo e o ensino migrou para o modo exclusivamente não presencial (por um período de, pelo menos, seis meses). Emergiram questões como a necessidade do contato, do afeto, o estresse das famílias, o reconhecimento da importância da escola na engrenagem de funcionamento da sociedade. Evidenciou-se a importância do papel do professor, com a publicação na imprensa de, por exemplo, depoimentos de pais sobre a dificuldade de ensinar a seus filhos os conteúdos mais elementares. Esperamos que dessa situação tão difícil emerjam melhorias para a escola, para a vida das famílias, para os professores, alunos e para a sociedade como um todo.

Por fim, gostaríamos de remeter, novamente, à epígrafe escolhida não apenas para abrir, mas também para nortear todo o caminho percorrido nesta tese: o chamado arendtiano de amor ao mundo por meio da responsabilidade com a educação das novas gerações. Em conjunto com Diana Barros, orientadora desta pesquisa, que o tem afirmado em diversas comunicações online durante o ano de 2020, em conjunto também com muitos outros educadores, políticos e pensadores que têm responsabilidade sobre o mundo, queremos reiterar nossa crença de que é por meio da educação na escola que se pode combater o ódio, a mentira e o autoritarismo que rondam nossa sociedade de modo mais acentuado e perigoso nos últimos anos. É preciso não esquecer que a educação e a construção de uma sociedade mais justa e democrática são, sempre, processos inacabados, como nos lembra Paulo Freire, trazido para o início deste capítulo de conclusão. Esse inacabamento é responsável pela beleza do processo, que sempre se aperfeiçoa e se renova para que nele caibam os recém-chegados ao mundo, mas também traz consigo a angústia da complexidade da incompletude e da necessidade de seguir, apesar dos pesares. Queremos também reiterar a importância de se buscar incessantemente meios de se fazer da tecnologia não apenas uma aliada cada vez maior para educar para a cidadania e para a plenitude, como também para 
incluir, nos processos de educação e no conteúdo cultural que se transmite, um número cada vez maior de pessoas e de histórias, abarcando todos, todas e todes, sem distinção. Se, de algum modo, esta tese puder ter contribuído com reflexões e análises que visem a esses fins, damos nossos objetivos por atingidos. 


\section{Referências bibliográficas}

ALMEIDA, Silvio Luiz. Entrevista a Fernando Haddad, outubro de 2020. Disponível em https://youtu.be/NQ3C_PxCuek Acesso em outubro de 2020.

ALONSO ALDAMA, Juan. Crise et imprévisibilité. In: STAY STANGE, V., HACHETTE, P. e HORREIN, R. (éds.). Sens à l'horizon. Hommage à Denis Bertrand. Limonges : LambertLucas, 2019a.

ALONSO ALDAMA, Juan. As transparências enganam. In: Revista Estudos Semióticos. Vol. 15, n. 1, agosto de 2019b. pp. 152-161.

ARENDT, Hannah. La Crise de l'éducation. extrait de La Crise de la culture. FolioPlus Philosophie (França), 2007.

ARENDT, Hannah. Entre o passado e o futuro. São Paulo: Perspectiva, 2014.

ARMSTRONG, Patricia. Bloom's Taxonomy. Página do site da Vanderilt University. Disponível em https://cft.vanderbilt.edu/guides-sub-pages/blooms-taxonomy/ acesso em setembro de 2020.

BAKHTIN, Mikhail. Marxismo e filosofia da linguagem. São Paulo: Hucitec, 2006.

BAKHTIN, Mikhail. Os gêneros do discurso. in BAKHTIN, Mikhail. Estética da Criação Verbal. Trad. Paulo Bezerra. 6 ${ }^{a}$ ed. São Paulo: Martins Fontes, 2011.

BÁRCENA, Fernando. Hannah Arendt. A educação como experiência do tempo: uma filosofia para a educação. In: CARVALHO, Alexandre F. e AZEREDO, Vânia Dutra. Filosofia e Educação no Mundo Contemporâneo. São Paulo: Humanitas, 2016.

BARROS, Diana Luz Pessoa de. Sintaxe Narrativa. In: OLIVEIRA, Ana Cláudia e LANDOWSKI, Eric. Do inteligível ao sensível. São Paulo: EDUC,, 1995. 
BARROS, Diana. Teoria do Discurso. Fundamentos Semióticos. 3a ed. São Paulo: Humanitas / FFLCH-USP, 2002.

BARROS, Diana. Teoria Semiótica do Texto 4aed. São Paulo: Ed. Ática, 2003.

BARROS, Diana Luz Pessoa de. A construção discursiva dos discursos intolerantes. in BARROS, D. L. P. de. (org.) Preconceito e intolerância. Construções linguístico-discursivas. São Paulo: Universidade Presbiteriana Mackenzie, 2011.

BARROS, Diana Luz Pessoa de. A Complexidade Discursiva na Internet. in CASA: Cadernos de Semiótica Aplicada, v.13, n.2, 2015, p. 13-31.

BARROS, Diana Luz Pessoa de. Estudos discursivos da intolerância: o ator da enunciação excessivo. Caderno de Estudos Linguísticos. Número 58.1. pp. 7-24. Campinas, 2016a.

BARROS, Diana Luz Pessoa de. O texto na Semiótica. in BATISTA, Ronaldo de O. (org.) 0 texto e seus conceitos. São Paulo: Parábola Editorial, 2016b.

BARROS, Diana Luz Pessoa de. Les régimes de sens et d'intéraction dans la conversation. Actes Semiotiques. Número 120, 2017.

BARROS, Diana Luz Pessoa de. Algumas reflexões sobre o papel dos estudos linguísticos e discursivos no ensino-aprendizagem na escola. Estudos Semióticos. Vol. 15, n. 2. São Paulo, dezembro de 2019.

BARROS, Diana Luz P. de; FIORIN, José Luiz (orgs.). Dialogismo, Polifonia, Intertextualidade. Em torno de Bakhtin. $2^{a}$ ed. São Paulo: Editora da Universidade de São Paulo, 2011.

BENVENISTE, Émile. Problemas de Linguística Geral I e II. 5ae ed. Campinas: Pontes, 2005.

BERTRAND, Denis. Caminhos da Semiótica Literária. Bauru, SP: Edusc, 2003.

BRAIT, Beth. (org.) Bakhtin, dialogismo e construção do sentido. $2^{\text {a }}$ ed. rev. Campinas, SP: Editora da Unicamp, 2005.

BRAIT, Beth. Estilo. In BRAIT, Beth (org.). Bakhtin. Conceitos-chave. São Paulo: Contexto, 2016.

BRASIL. Secretaria de Educação Fundamental. Parâmetros curriculares nacionais: terceiro e quarto ciclos do ensino fundamental: introdução aos parâmetros curriculares nacionais / Secretaria da Educação Fundamental. Brasília: MEC/SEF, 1998a.

BRASIL. Secretaria de Educação Fundamental. Parâmetros curriculares nacionais: terceiro e quarto ciclos do ensino fundamental: língua portuguesa / Secretaria da Educação Fundamental. Brasília: MEC/SEF, 1998b. 
BRASIL, Ministério da Educação. Diretrizes Curriculares Nacionais Gerais da Educação Básica. Ministério da Educação. Secretaria de Educação Básica. Diretoria de Currículos e Educação Integral. Brasília: MEC, SEB, DICEI, 2013.

BRASIL. Ministério da Educação. Base Nacional Comum Curricular. Educação é a base. Brasília: MEC, 2017. Disponível em http://basenacionalcomum.mec.gov.br/images/BNCC_El_EF_110518_versaofinal_site.pdf acesso em abril de 2019.

BOTO, Carlota. Instrução pública e projeto civilizador. O século XVIII como intérprete da ciência, da infância e da escola. São Paulo: Editora da Unesp, 2017.

CANDAU, Vera Maria. A didática e a formação de educadores. Da exaltação à negação: a busca da relevância. In: CANDAU, Vera M. (org.). A didática em questão. 33a ed. Petrópolis, RJ: Ed. Vozes, 2012.

CÉSAR, Maria Rita de Assis. A educação num mundo à deriva. In: Revista Educação. Hannah Arendt Pensa a educação. São Paulo, Ed. Segmento, 2014.

CÉSAR, Maria Rita de Assis. DUARTE, André. Hannah Arendt: pensar a crise da educação no mundo contemporâneo. In: Revista Educação e Pesquisa. v. 36, n. 3, p. 823-837. set./dez. 2010.

CORDEIRO, Jaime. Didática. São Paulo: Contexto, 2015.

CORTINA, Arnaldo e MARCHEZAN, Renata C. Teoria Semiótica: a questão do sentido. in MUSSALIM, Fernanda e BENTES, Anna Christina. (org.) Introdução à Linguística:

fundamentos epistemológicos. vol. 3 São Paulo: Cortez, 2004.

COSTIN, Cláudia. O professor e o orgulho profissional. Jornal Folha de São Paulo.

Disponível em https://www1.folha.uol.com.br/colunas/claudia-costin/2020/10/o-professore-o-orgulho-profissional.shtml Acesso em 29/10/2020.

COUTINHO, Mariana de Souza e MANCINI, Renata. Graus de concessão, as dinâmicas do inesperado. Estudos Semióticos. Vol. 16, n. 2, outubro de 2020.

CRUZ, Dilson Ferreira da. Algumas considerações sobre o crer e o saber. Revista Estudos Semióticos. Número 4. São Paulo, 2008.

DALSUET, Anne. Dossier et notes: Le texte en perspective. In: ARENDT, Hannah. La Crise de l'éducation. Extrait de La Crise de la culture. Folio Plus Philosophie (França), 2007.

DISCINI, Norma. Jornal: um modo de presença. Revista Galáxia. n. 5, abril de 2003. pp. 109-127. 
DISCINI, Norma. O Estilo nos Textos. 2 2a ed. São Paulo: Contexto, 2004.

DISCINI, Norma. Semiótica: da imanência à transcendência (questões sobre o estilo). Revista Alfa. São Paulo, 53 (2): 595-617. 2009.

DISCINI, Norma. Para o estilo de um gênero. Revista Bakhtiniana. São Paulo, 7 (2): 75-94. 2012. Disponível em http://revistas.pucsp.br/index.php/bakhtiniana/article/view/9934 acesso em 08/julho/2015

DISCINI, Norma. Corpo e Estilo. São Paulo: Contexto, 2015.

DOSSE, François. Histoire du Structuralisme I e II. Paris: Éditions la Découverte, 1992.

FERRAZ, Ana P. C. M. BELHOT, Renato V. Taxonomia de Bloom: revisão teórica e apresentação das adequações do instrumento para definição de objetivos instrucionais. Gest. Prod., São Carlos, SP, v. 17, n. 2, p. 421-431, 2010

FIORIN, José Luiz. Linguagem e ideologia. São Paulo: Ática, 1988.

FIORIN, José Luiz. A lógica da neutralidade: um caso de aspectualização do ator. In: Estudos Linguísticos XVIII, 1989, Lorena, São Paulo. Anais... pp. 348-355.

FIORIN, José Luiz. As astúcias da enunciação. São Paulo: Contexto, 2002.

FIORIN, José Luiz. Em busca do sentido. Estudos discursivos. São Paulo: Contexto, 2008.

FIORIN, José Luiz. Introdução ao pensamento de Bakhtin. $2^{\mathrm{a}}$ ed. São Paulo: Contexto, 2016.

FIORIN, José Luiz (org.). Semiótica tensiva. In: Novos caminhos da linguística. São Paulo: Contexto, 2017.

FIORIN, José Luiz. Duas concepções de enunciação. Revista Estudos Semióticos. vol. 16, num. 1, 2020.

FLORES, Valdir N. TEIXEIRA, Marlene. Introdução à Linguística da Enunciação. São Paulo: Ed. Contexto, 2005.

FONTANILLE, Jacques. ZILBERBERG, Claude. Tensão e Significação. Trad. de Ivã Lopes, Luiz Tatit e Waldir Beividas. São Paulo: Discurso Editorial / Humanitas / FFLCH, USP, 2001.

FONTANILLE, Jacques. Semiótica do discurso. Trad. de Jean Cristtus Portela. $1^{\text {a }}$ ed. São Paulo: Ed. Contexto, 2007. 
FONTANILLE, Jacques. A semiótica hoje: avanços e perspectivas. Revista Estudos Semióticos. vol. 12, num. 2, 2016.

FREIRE, Paulo. Pedagogia da Autonomia. Saberes necessários à prática educativa. $54^{\mathrm{a}}$ edição. Rio de Janeiro: Paz e Terra, 2016.

FREIRE, Paulo. Carta de Paulo Freire aos professores. Estud. av., São Paulo, v. 15, n. 42. Agosto de 2001. Pp. 259-268. http://dx.doi.org/10.1590/S0103-40142001000200013.

GAUTHIER, Clermont; TARDIF, Maurice (orgs.). A pedagogia. Teorias e práticas da Antiguidade aos nossos dias. Petrópolis: Vozes, 2014.

GIANETTI, Eduardo. O valor do amanhã. São Paulo: Cia. das Letras, 2005.

GOMES, Regina Souza. Um olhar semiótico sobre a atualidade: a aspectualização a partir de Greimas. Revista Estudos Semióticos. Vol. 14, n. 1, São Paulo, março de 2018.

GOMES, Regina. Crise de veridiç̧ão e interpretação: contribuições da semiótica. Estudos Semióticos. Vol. 15, n. 2. São Paulo, dezembro de 2019.

GREIMAS, Algirdas Julien. L'Enonciation: une posture épistémologique. In: Significação Revista Brasileira de Semiótica, no 1, Centro de Estudos Semióticos A. J. Greimas: Ribeirão Preto (SP), 1974. pp. 09-25.

GREIMAS, Algirdas Julien. Sobre o Sentido. Ensaios Semióticos. Petrópolis: Vozes, 1975.

GREIMAS, Algirdas Julien. Pour une semiotique didactique. In: Le Bulletin du Groupe de Recherches sémio-linguistiques - CNRS. 1979.

GREIMAS, Algirdas Julien. Do discurso científico em Ciência Sociais. In: GREIMAS, A. J. Semiótica e Ciências Sociais. Trad. de Álvaro Lorencini e Sandra Nitrini. São Paulo: Cultrix, 1981.

GREIMAS, Algirdas Julien. Sobre o Sentido II. Ensaios semióticos. Tradução de Dilson F. da Cruz. São Paulo: Nakin: Edusp, 2014.

GREIMAS, Algirdas Julien. COURTÉS, J. Dicionário de Semiótica. São Paulo: Cultrix, s/d. (original francês de 1979).

GRILLO, Marlene. Professor deve usar o plano de aula como guia, permanecendo atento aos imprevistos. Entrevista ao Jornal do Professor, edição 6, outubro de 2008. Disponível em http://portaldoprofessor.mec.gov.br/jornal.html 
HAROCHE, Claudine. Crise da consciência contemporânea e expansão do saber nãocumulativo. Tradução de Lólio Lourenço de Oliveira e revisão técnica de Olgária Matos.

Revista Educação e Pesquisa. São Paulo, v. 31, n. 3, pp. 347-362, 2005.

HAROCHE, Claudine. Crise de la conscience contemporaine et expansion d'un savoir non cumulatif. Cahiers Internationaux de sociologie. n. 125. 2008. pp. 331 - 346. Disponível em https://www.cairn.info/revue-cahiers-internationaux-desociologie-

2008-2-page-331.htm

HÉNAULT, Anne. História Concisa da Semiótica. São Paulo: Parábola editorial, 2006.

HJELMSLEV, Louis. Prolegômenos a uma Teoria da Linguagem. $2^{\mathrm{a}}$ ed. São Paulo:

Perspectiva. 2003.

LANDOWSKI, Eric. Régimes de sens et styles de vie. Actes Sémiotiques [Online] . N 115 , 2012. Disponível em: http://epublications.unilim.fr/revues/as/2647 Acesso em 28/06/2017.

LANDOWSKI, Eric. Interações Arriscadas. São Paulo: Estação das Letras e Cores, 2014.

LASLEY II, Thomas J. Bloom's Taxonomy. Artigo para a Encyclopedia Britannica [online]. Disponível em: https://www.britannica.com/topic/Blooms-taxonomy acesso em janeiro de 2020.

LEGENDRE, Marie-Françoise. Jean Piaget e o construtivismo na educação. In: GAUTHIER, Clermont, TARDIF, Maurice (orgs.). A pedagogia. Teorias e práticas da Antiguidade aos nossos dias. Petrópolis: Vozes, 2014a.

LEGENDRE, Marie-Françoise. Lev Vygotsky e o socioconstrutivismo na educação. In: GAUTHIER, Clermont, TARDIF, Maurice (orgs.). A pedagogia. Teorias e práticas da Antiguidade aos nossos dias. Petrópolis: Vozes, 2014b.

LOPES, Ivã C.; BEIVIDAS, Waldir. Argumentação e Persuasão. Tensão entre crer e saber em "Famigerado", de Guimarães Rosa. Revista Alfa. Número 53. pp. 443-455 São Paulo, 2009.

LOTMAN, Yuri. Preface. In: Universe of the Mind: A semiotic theory of culture. Indiana University Press, 1990

MACHADO, Irene. Os gêneros e o corpo do acabamento estético. in: BRAIT, Beth (org.). Bakhtin. Dialogismo e construção do sentido. Campinas: Ed. da Unicamp, 2005.

MACHADO, Nilson José. Epistemologia e Didática. As concepções de conhecimento e inteligência e a prática docente. $2^{\text {a }}$ edição. São Paulo: Cortez Editora, 1996.

MALHEIROS, Bruno Taranto. Didática Geral. Org. Andrea Ramal. Rio de Janeiro: LTC, 2013. 
MANCINI, Renata. A enunciação tensiva em diálogo. Estudos Semióticos, v. 15, p. 64-87, 11 abr. 2019.

MARTINS, Paulo Henrique. A sociologia de Marcel Mauss: dádiva, simbolismo e associação. Revista Crítica de Ciências Sociais. N. 73 (2005). pp.45-66). Disponível em https://journals.openedition.org/rccs/954 acesso em março de 2020.

MASCARO, Alysson. Entrevista ao canal Tutameiatv, "Tutaméia entrevista Alysson Mascaro", em março de 2020. Disponível em https://www.youtube.com/watch?v=JPJRLDBXiQU, acesso em março de 2020.

MATTE, Ana C. Fricke. Sementres de Educação Aberta e Cultura Livre. Coleção Texto Livre: Pensemeando o mundo. Sao Carlos: Pedro e João Editores, 2018.

MATTE, Ana Cristina Fricke. Pensamentos em Semiótica: Canção, Educação e Tecnologia. Coleção Texto Livre: Pensemeando o Mundo. São Carlos: Pedro e João Editores, 2019.

MOREIRA, Renata Lúcia. Um olhar da semiótica para os Discursos em Libras: Descrição do Tempo. Tese de doutorado. Universidade de São Paulo, USP. São Paulo-SP, 2016.

NORONHA, Ana Carolina Cortez. A viagem de um leitor: uma investigação semiótica sobre o processo de leitura. Dissertação de mestrado. Universidade Estadual Paulista Júlio de Mesquita Filho, UNESP. Araraquara-SP, 2006.

NORONHA, Ana Carolina Cortez. Considerações semióticas sobre o uso da tecnologia digital em sala de aula. Estudos Semióticos. Vol. 15, n. 2, dezembro de 2019.

PEREIRA, Daniervelin Renata Marques. Semiótica e ensino: ajustamentos sensíveis em gêneros digitais da esfera educacional. Tese de doutorado. Universidade de São Paulo, USP. São Paulo-SP, 2013.

PLATÃO, Francisco e FIORIN, José L. Lições de texto: leitura e redação. $4^{a}$ ed. São Paulo: Editora Ática, 2003.

PORTAL do Professor. Ministério de Educação e Cultura (MEC).

http://portaldoprofessor.mec.gov.br

PORTELA, Jean Cristtus. Práticas Didáticas: um estudo sobre os manuais brasileiros de semiótica greimasiana. Tese de doutorado. Universidade Estadual Paulista Júlio de Mesquita Filho, UNESP. Araraquara-SP, 2008.

PORTELA, Jean Cristtus. Semiótica Didática: percurso histórico-conceitual de uma prática de análise. Estudos Semióticos. Vol. 15, n. 2. São Paulo, dezembro de 2019. 
RASTIER, François. Éducation et idéologie managériale. Entretien avec AL-MATARY, Sarah e CHEVALIER, Yannick. Texto! Texte et culture. Vol. XIX n. 4, 2014.

RASTIER, François. Sémiotique de la Transmission. In: Acta Semiotica et Linguistica. v. 20 num. 2, 2015.

SERTÃ, Ana Luísa e ALMEIDA, Sabrina. 2016. "Ensaio sobre a dádiva". In: Enciclopédia de Antropologia. São Paulo: Universidade de São Paulo, Departamento de Antropologia. Disponível em: <http://ea.fflch.usp.br/obra/ensaio-sobre-dádiva> acesso em março de 2020.

SOUZA SANTOS, Boaventura de. Entrevista a Vinicio Chacón publicada online em Semanario Universidad em 26 de novembro de 2019. Disponível em https://semanariouniversidad.com/universitarias/el-neoliberalismo-esta-mostrando-sunueva-fase-la-incompatibilidad-con-la-democracia/, acesso em março de 2020.

SHIMODA, Lucas. FERREIRA Luiz Fernando. O ensino de coerência textual em enunciados verbais e não-verbais: uma abordagem alternativa. Estudos Semióticos, 15(2), 2019. Pp. 158-180. Disponível em https://doi.org/10.11606/issn.1980-4016.esse.2019.160575 acesso em julho de 2020.

SCHWARTZMANN, Matheus Nogueira. A noção de texto e os níveis de pertinência da análise semiótica. Estudos Semióticos. vol. 14 n. 1. São Paulo, março de 2018.

TATIT, Luiz. Abordagem do texto. in FIORIN, José Luiz (org.). Introdução à Linguística I. Objetos Teóricos. 4ª ed. São Paulo: Contexto, 2005.

TATIT, Luiz. Semiótica à luz de Guimarães Rosa. São Paulo: Ateliê Editorial, 2010.

TATIT, Luiz e BEIVIDAS, Waldir. Potencialidades da Narrativa Greimasiana. Estudos Semióticos. vol. 14, n. 1, p.45-54, março 2018.

TEIXEIRA, Lucia. Contribuições da semiótica para a análise dos discursos na internet. Entrepalavras. Fortaleza-CE, v. 10, n. esp., fev. 2020.

UNICEF (Fundo das Nações Unidas para a infância). Declaração Mundial sobre Educação para Todos (Conferência de Jomtien, 1990), 1990. Disponível em https://www.unicef.org/brazil/declaracao-mundial-sobre-educacao-para-todos-conferenciade-jomtien-1990 acesso em outubro de 2020.

VARKEY Foudantion. Reading between the lines. Relatório 2020. https://www.varkeyfoundation.org/media/6525/reading-between-the-lines.pdf Acesso em outubro de 2020. 
ZILBERBERG, Claude. Síntese da gramática tensiva. Significação: Revista De Cultura Audiovisual, 33(25), 2006a. pp. 163-204. https://doi.org/10.11606/issn.23167114.sig.2006.65626

ZILBERBERG, Claude. Razão e Poética do Sentido. Trad. de Ivã Lopes, Luiz Tatit e Waldir Beividas. São Paulo: Edusp, 2006b.

ZILBERBERG, Claude. Louvando o acontecimento. Tradução de Maria Lúcia Vissotto Paiva Diniz. Galáxia. São Paulo, n. 13, p. 13-28, 2007.

ZILBERBERG, Claude. Elementos de Semiótica Tensiva. Trad. de Ivã Lopes, Luiz Tatit e Waldir Beividas. São Paulo: Ateliê Editorial, 2011. 


\section{ANEXOS}

I Jornal do Professor 


\section{D] Portal do Professor}

\section{Planejamento Escolar

$$
\text { exta-feira, } 3 \text { de Outubro de } 2008
$$

Edição 6

EDITORIAL - Planejamento Escolar

Nesta sexta edição, o Jornal do Professor trata do tema Planejamento Escolar. Como sempre, o assunto atende aos pedidos dos leitores, tendo sido o mais votado na enquete colocada em nossa página.

Você vai ler, entre outros temas, sobre o que deve ser levado em consideração na hora de montar um plano escolar, curricular e de aula; qual é a importância de um plano de aula; como utilizar as aulas disponiveis no Portal do Professor e como criar as suas próprias.

Você também vai conhecer experiências de planejamento desenvolvidas em escolas das regiōes Norte, Nordeste, e Su do Brasil.

Ajude-nos escolher o tema das próximas ediçōes, votando na enquete colocada em nossa página. E aproveite para

Seja bem-vindo!

Professor deve usar plano de aula como guia, permanecendo atento aos imprevistos

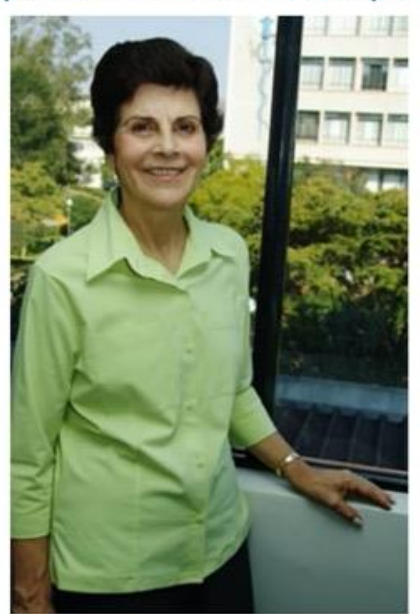

O plano de aula é uma ferramenta muito importante para o professor. Por meio dele, o educador pode fazer a previsão

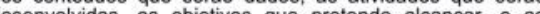
formas de avaliaçăo.

Para falar sobre este tema, o Jornal do Professor entrevistou

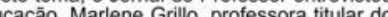
Programa de Pós-Graduação em Educação da Pontifícia Universidade Católica do Rio Grande do Sul (PUCRS) assessora pedagógica da Pró-Reitoria de Graduação da mesma instituiçăo.

\section{JP - O que é e para que serve o plano de aula?}

MG - Falar sobre plano de aula, mesmo que se pretenda ser breve, encaminha a um referencial teórico que reúne dimensőes filosóficas, psicológicas e sociais com A experiência cotidiana mostra que a concepçăo de planejamento tem passado por várias modificações: entendido como instrumento obrigatório, definitivo e inflexivel, passando pela dispensabilidade, até chegar quase técnica e mais de uma questão filosófico-pedagógica questá

Um plano de aula tem sempre sua origem num projeto pedagogico institucional que dinamiza as direçoes do ensino, detalhadas num plano de curso e de unidade. E uma previsăo de atividades vinculadas a um plano de ensino mais consonância com objetivos e conteúdos previstos. Serve para organizar a intençăo do professor e o modo de operacionaliza-la. Expressa, ainda, as opcooes desse professor diante de seu contexto de trabalho, que implica pensar simultaneamente o conteúdo e os sujeitos com os quais interage.

Todo plano de aula, além de ser um guia, traz implicitas questōes pessoais do professor comprometido com sua larefa e com seus alunos: por que faço o que faço ao ensinar? o que e uma aula. espaço de parceria ou de resistencia? como mobilizar o aluno para aprender? como

JP - Qual sua importância?

MG - O plano possibilita ao professor, na medida 


\section{ब] Portal do Professor}

\section{Planejamento Escolar}

Edição 6

do possivel e do desejável, manter a articulaçāo da disciplina como um todo pela relaçáo com o plano de ensino $e$ aind realizar uma auto-avaliação da aula ou uma avaliação cooperativa para orientar decisōes futuras. Aspectos a serem seguranca Cabe destacar que o plano de aula não implic obrigatoriamente seu cumprimento rígido. O cenário da aula exige permanente atitude reflexiva do professor para recriar e redirecionar açōes sempre que novos interesses necessidades imprevistas surgirem, 0 que não significa despreparo docente, mas competência para "agir na Untretanto, um afastamento continuo do plano necessita ser revisado.

O plano, como resultado do processo de planejamento, permite ao professor distanciar-se de sua prática organização da aula 0 plano documenta a experiência em suas intenções iniciais e permite o retorno a ela após o vivido para sua avaliaçắo.

\section{JP - O que deve ser
elaboraçăo de um plano?}

MG - Um plano, para ser efetivo, deve apresentar, de forma precisa e orgânica, o objetivo da aula, o conteứdo a ser entender que avaliar náo é sino̊nimo de prova nem de E diagnosticar se a aprendizagem ocorreu ou não e explicita açōes para continuidade ou reorientaçăo do processo de ensino.

JP - Modelo para construção de um plano de aula

MG - Mais do que saber elaborar um plano, é necessário acreditar que ele é o instrumento pessoal e intransferivel de trabalho do professor, e expressa as concepçōes teóricas que sustentam suas atividades docentes. Importante não registro dos aspectos que orientam o professor par buruturar a prastca. auto-organizaçăo do professor na elaboração do plano.

JP - Dicas para professores novos

MG - Além de elaborar o plano, o professor deve levar em con alunos as percebem, pois às vežes sấ o modo com pequenos ajustes em qualquer dos elementos do plano para uma boa conduçăo da aula.

(Fátima Schenini)
Planejamento é fator importante em escolas do Pará e Alagoas

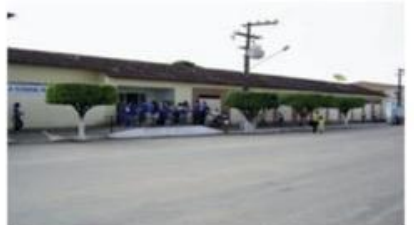

Na Escola Estadual Padre Aurélio Góis, localizada no Maceió, o planejamento é uma tarefa conjunta, que tem como objetivo traçar metas para saber aonde chegar.

De acordo com a diretora da instituição, Maria Salete dos Santos Ribeiro, o planejamento do ano letivo é feito pelos diretores e coordenadores e depois repassado para os

No inicio do segundo semestre do ano letivo, em agosto, eita nova reuniaao para analisar os resultados obtidos e verificar o que pode ser melhorado e o que deve ser

Os professores não ficam sós. A direção e os coordenadores pedagogicos estấo sempre em contato com eles, incentivando-os e estimulando-os para que descubram novos meios de se aperfeiçoarem," salienta Maria Salete.

A coordenadora pedagógica do ensino fundamental da Padre Gois, Rejane Maria Vieira da Silva, explica que a escola tambem promove encontros do conselho de classe. São duas reunioes por semestre, com a participação de diretores, a participação do aluno nesses encontros, é importante, pois a participação do aluno, nesses encontros, é importante, pois processo sajeito que justifica a existencia da escola. "O pefende também a participaçáo dos pais: "a comunidade confia na escola e a escola confia na família dos alunos", justifica.

Com 908 alunos do $7^{\circ}$ ano do ensino fundamental ao $3^{\circ}$ ano do ensino médio, nos três turnos, a instituição deu um salto De 3,1 em 2005 passou para 4,9 em 2007, atingindo o valor previsto para 2019.

Na Escola Municipal Deputado Ubaldo Corrêa, em Santarém PA). município situado na confluência dos rios Amazonas 


\section{D] Portal do Professor}

\section{Planejamento Escolar}

Edição 6

amplo e detalhado, engloba a planificaçāo dos instrumentos que propōem açōes e metas a serem alcançadas proposta pedagogica, o plano anual de metas, e o plano de

De acordo com o vice-diretor da instituiçăo, Ernany Santos de Almeida, no inicio de cada ano é realizada uma jornada pedagógica, onde os professores analisam os dados do rendimento escolar, os objetivos e metas previstos para o dados estatisticos registrad novas açoes. Ele explica que os de aprovaç̃o, reprovaçăo, evasão e faltas, são analisado em conjunto, pela equipe gestora da escola, pais e alunos. E a cada semestre, eles avaliam as praticas pedagógicas propōem melhorias nas açōes para o ensino aprendizagem.

A escola também promove inúmeras atividades curriculares e extracurriculares que contribuem para fortalecer trabalho escolar e de crescimento profissional, tais com encontros pedagógicos e administrativos e reuniōes do conselho escolar e do conselho de classe.

Compromisso - "A educaçăo só vai mudar quando todos os responsáveis, incluindo aí professores, gestores, alunos, pais, vigias, serventes, enfim, a comunidade em geral," diz diretora da Ubaldo Correa, Naide Iraci Sousa da Siva. "Em nossa escola ja está acontecendo de o pessoal responsáve pela mé comprometer com a educaçō", ressalta.

Maior escola da rede do municipio, a Ubaldo Corrêa atende 1.180 alunos dos anos finais do ensino fundamental $\left(6^{\circ} \mathrm{a}\right.$ 9), distribuidos nos turnos matutino e vespertino. Com $3,8 \mathrm{em} \mathrm{2005}$, atingiu, em 2007, o valor de 4,1, maior do que estava previsto para 2009 , que era de 4,0 .

As duas instituiçōes receberam o Prêmio Nacional de Referência em Gestão Escolar - Ciclo 2006-2007, promoçẩo (Conta do Educaçă (Undime) da Organização das Nacōes Unidas para a Educação, a Ciência e a Cultura (Unesco) e da Fundação Roberto Marinho.

(Fátima Schenini)

Aulas bem planejadas

estimulam

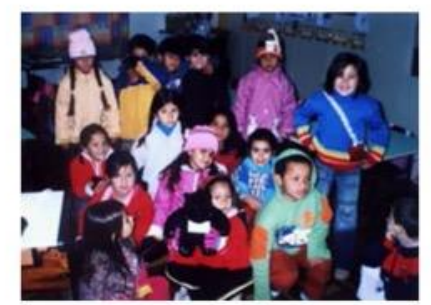

Duas professoras do interior do pais apostaram em novaçoes para mudar a rotina de suas escolas. Situadas em realidades diferentes, uma no Rio Grande do Sul (RS) e outra no Ceara (CE), elas buscaram meios alternativos para pla do ponto de partida para

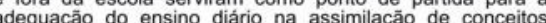
básicos sócio-culturais.

Em Nova Hamburgo, municipio de colonização alemã a 40 Km de Porto Alegre (RS), a professora Juceli Hack de Vereador Arnaldo Reinhardt, elaborou o projeto A Mäe Africa e Seus Filhos Brasileiros, a partir de uma crianca negra que entrou na escola em que prevalecem criancas de cor branca. Ao detectar o preconceito, surgiu a idéía de introduzir outras culturas, principalmente as africanas, na rotina dos alunos. ma das atividades adotadas foj o recebimento de visitas de capoeira e missionários atuantes naquele continente-

O projeto teve duração de dez meses. A professora ia planejando as aulas de acordo com a avaliação semanal dos alunos e o retorno da tamilia. "No inicio, os pais năo mench mesmos e dos outros paises", diz Juceli.

Segundo a professora, a escola também não foi muito receptiva no inicio e nảo ajudou no planejamento. Mas após os bons resultados obtidos com as crianças, a escola apoiou projeto que deu a Juceli o prêmio Professores do Brasil, edição 2005. A premiação e uma iniciativa do MEC em parceria com o Conselho Nacional de Secretários de Educação (Consed), a União Nacional dos Dirigentes Municipais de Educaçăo (Undime), e fundaçōes Bunge

Em Cágado, distrito rural de São Gonçalo do Amarante 


\section{D] Portal do Professor}

\section{Planejamento Escolar}

Edição 6

(CE), a cerca de $60 \mathrm{Km}$ de Fortaleza, a professora da Escola de Ensino Fundamental Joāo Pinto Magalhāes, Francisca das Chagas Menezes Sousa, utilizou uma ferramenta diferente, a literatura de cordel. O projeto Cordel: rimas que Educadora do Ano.

Ao identificar problemas de escrita e leitura em seus alunos do $9^{\circ}$ ano, a professora percebeu que utilizar cordéis serí os alunos foram pegando com contos recheados de rimas. O distrito foi contribuindo para o planejamento do projeto e alimentando o acervo dos cordéis.

Segundo a professora, todo o planejamento é baseado nas necessidades necessidades dos alunos. "A maior dificuldade dos meus Com o cordel eles aprenderam a identificar cada uma", destaca. Após estimular a leitura dos cordéis, a professor sentiu a necessidade de que os próprios estudantes construissem os seus, escrevendo sobre o cotidiano. Estimulante - De acordo com as duas professoras, é muito mais estimulante trabalhar com projetos inovadores. Planejar aulas tendo como meta um objetivo maior do que os rotineiros alimenta a vontade de ensinar e estimula planejamento de novos projetos. Aulas bem planejadas diferenca no aprendizado de gualquer estudante. (Assessoria de Comunicaçāo da Seed/MEC)

Portal do Professor auxilia a planejar aulas

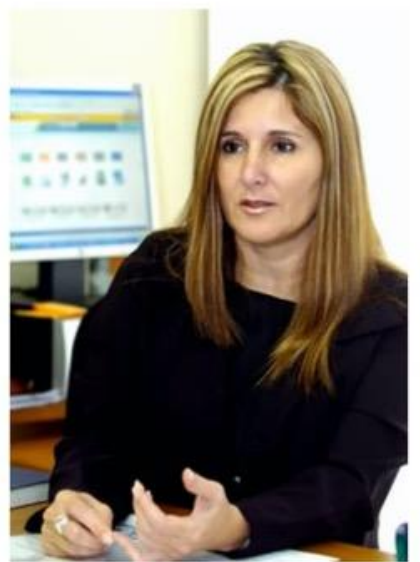

Sugestōes de aulas de acordo com o curriculo de cada disciplina, alem de recursos multimidia como videos, fotos, dinânico e interessante para o aluno estăo nas secỗes Espaço da Aula e Recursos Educacionais, do Portal do dos professores, os conteúdo podem auxiliar no preparo das aulas e enriquecer a aprendizagem dos estudantes.

Os professores das diferentes regióes brasileiras podem compartilhar suas idéias, propostas e sugestōes
metodológicas sobre o uso dos recursos multimidia e das
ferramentas digitais. "Queremos criar um intercâmbio de ferramentas digitais. "Queremos criar um intercâmbio de experiências para o desenvolvimento criativo de novas estratégias de ensino e aprendizagem
do Portal do Professor, Carmem Prata.

Ela destaca que, o importante é fortalecer a colaboração modo a que um possa ajudar a arática por um professor, podera estimular a outro ou fazer com que ferramenta de aprendizagem", salienta.

O Portal dispõe, no momento, de 270 sugestōes de aulas em diferentes disciplinas de ensino fundamental 
Edição 6

\section{Planejamento Escolar}

e médio. Elas podem ser lidas, comentadas, classificadas e

baixadas por qualquer interessado. Para acessá-las, as

opcōes sầo muitas: por nivel de ensino, componente melhor classificadas.

Caso o professor queira criar sua própria aula, deverá fazer

sua inscriçăo e login no ambiente do Portal, podendo

também inserir recursos disponiveis no menu Recursos

Educacion

Aprenda a criar sua própria aula.

(Fátima Schenini) 


Edição 6
Bancos ecológicos
Planejam
"Vamos criar novas possibilidades, olhar para nós e para o
mundo como se fóssemos um só e assim lutar por uma vida
melhor para todos". Deise Cargnelutti
Professora de artes no Colégio Estadual Catuipe, no
municipio de Catuipe, no Rio Grande do Sul, Deise
Cargnelutti queria construir alguma coisa com o lixo que
fosse útil e ao mesmo tempo pudesse ser desfrutado e
apreciado. Então, ela e alguns alunos do $8^{\circ}$ ano tiveram a
idéia de fazer bancos, aproveitando pneus velhos.




\section{D] Portal do Professor}

\section{Planejamento Escolar}

Edição 6

José Cerchi Fusari: "Planejar evita o excesso de improviso pedagógico".

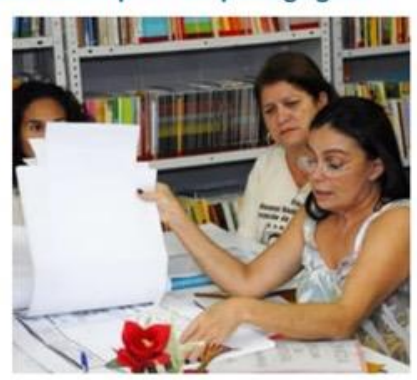

Com mais de 40 anos de experiência em educação, José educacional como uma atividade realizada durante todo ano letivo e não somente no início. Professor doutor da Faculdade de Educação da Universidade de São Paulo (USP), Fusari trabalhou sistematicamente na formação de educaçăo pela USP, mestre em filosofia da educacăo pela Pontificia Universidade Católica de São Paulo (PUC-SP), formado em pedagogia pela PUC-SP e egresso das antigas escolas normais de formaçăo de professores. Além da long experiência em ensino fundamental, médio e superior, no
momento coordena na FEUSP o Grupo de Estudos Pesquisas sobre Formaçăo de Educadores (GPEFE) JP - O que se entende por planejamento de ensino? Qual
o seu conceito?

JCF - A maioria das escolas brasileiras organiza no começo do ano uma semana de planejamento. Isso tem um lado positivo e negativo. Como náo ha uma cultura co somento no inicio do ano letivo. Planejar năo pode ser caracterizado como uma atividade datada e situada, deve ser um processo mais amplo, caso contrário, cairemos no "repentismo pedagógico" em que as escolas vivem de improvisos.

Sendo assim, o planejamento pode ser definido como um processo permanente, critico e reflexivo vivenciado pelos educadores, em especial, nos 200 dias letivos e para além deles. E muito mais amplo do que a elaboração de planos e projetos. Olanejamento ee uma atitude, um valo os educadores enquanto protagonistas do processo de educação escolar.

Atualmente, o planejamento escolar está estigmatizado como uma tarefa superflua, desnecessária e burocrática. Entretanto, e importante recuperar a identidade do planejamento transformado em cultura vai propiciar bons projetos, planos de aula e planos de ensino.

JP - É importante a participação da comunidade e dos conselhos escolares na hora de formular o plano de ensino? Como eles podem contribuir?

JCF - Toda escola se organiza a partir de um curriculo ormal, o qual serve de base para a construção de um Projeto Politico Pedagogico (PPP). A construçăo deste

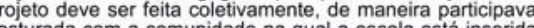
Por isso podemos dizer que o projeto é uma obra aberta. PPP está sempre sendo reinventado porque a relaçăo da escola com a comunidade é dinâmica.

A comunidade pode contribuir de várias formas. Sabemos ue existem escolas muito fechadas em relaçăo conseguem ter um conselhos escolares, que funcionando democra estabelecem um canal de comunicação rico e saudável para a escola. A escola tem que ir além do que é a expectativa da comunidade. para a educaçáo dos alunos, mas tambem para a educaçáo corna co-respensável pela escola e seu projeto pedagógioo.

JP - O que deve ser levado em consideração na hora de montar um plano escolar, curricular e de aula? JCF - O fundamental não é decidir se o plano será redigido
no formulário $x$ ou y, mas assumir que a açăo pedagógica necessita de um minimo de preparo, mesmo tendo o livro didático como um dos instrumentos comunicacionais no trabalho escolar em sala de aula. É importante desencadear um processo de repensar todo o ensino, buscando um significado 


\title{
D] Portal do Professor
}

\begin{abstract}
Ediçầo 6
Principios educacionais - Estâo presentes na Lei de Diretrizes e Bases da Educaçăo. Entretanto, é interessante que a escola se reúna e reescreva os princípios levando em consideraçăo as situaçōes locais. Os principios são o ponto é interessante que acompanhe todo o processo de planejamento escolar.

Objetivos - Estes são os pontos de chegada, onde se pretende chegar com as atividades da escola, de cada pretende chegar com
disciplina e das aulas.

Conteúdo - É necessário também prever o conteúdo como um recorte do conhecimento que fará parte de cada disciplina. Conhecimento este produzido históricamente pela humanidad

Métodos de ensino - Concomitante a definição dos objetivos que constituem o ponto de partida para qualquer método de ensino, cumpre ao professor e supervisor o planejamento de luno situacónes capazes de produzir aprendizarar critico-reflexivas.

Avaliação - A avaliação é o processo pelo qual a escola e os professores procuram determinar a qualidade quantidade de mudanças efetuadas na aprendizagem do objetivos, conhecimentos, metas e sistemas de avaliaçăo. As situacōes de avaliação são mais facilmente escolhidas planejadas quando os objetivos são bem definidos.
\end{abstract}

\section{Planejamento Escolar}

fusari@usp.br

JP - Qual plano deve ser prioritário: escolar, curricular ou de aula?

JCF - Os três tipos de plano se complementam, se interpenetram e compōem o corpo do plano de curriculo da escola. Entretanto, na prática das unidades escolares, devido a quase total falta de condiçoes de trabalno docente, a revelado complexa, frome casos, daquela organicidade desejada para o processo de ensino e aprendizagem.

$\mathrm{Na}$ atual conjuntura problemática em que se encontram a escola, vamos estimular os professores a prepararem as suas aulas, garantindo, deste modo, um trabalho mais interessante $e$ produtivo no processo ensino aprendizagem, no qual o professor seja um bom mediado os conteúdos do ensino. 
II Tutorial "Como criar uma aula?" 
()

\section{Como criar uma aula?}

\section{()}

Para criar uma sugestão de aula é necessário que você já tenha se cadastrado no Portal do Professor e esteja logado.

(1) Caso ainda não tenha feito seu login, o sistema solicitará a sua identificaçāo.

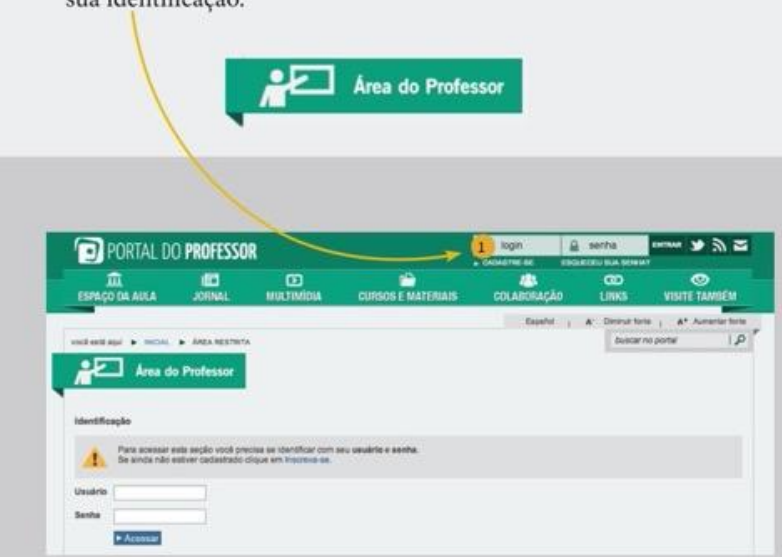

(2) Se você não tiver cadastro no Portal do professor, clique em CADASTRE-SE localizado na primeira página do Portal.

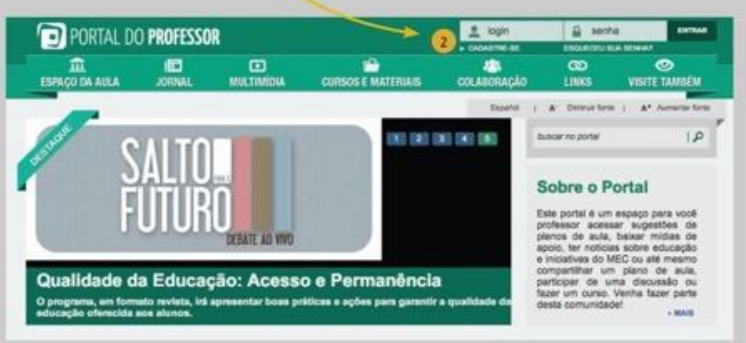



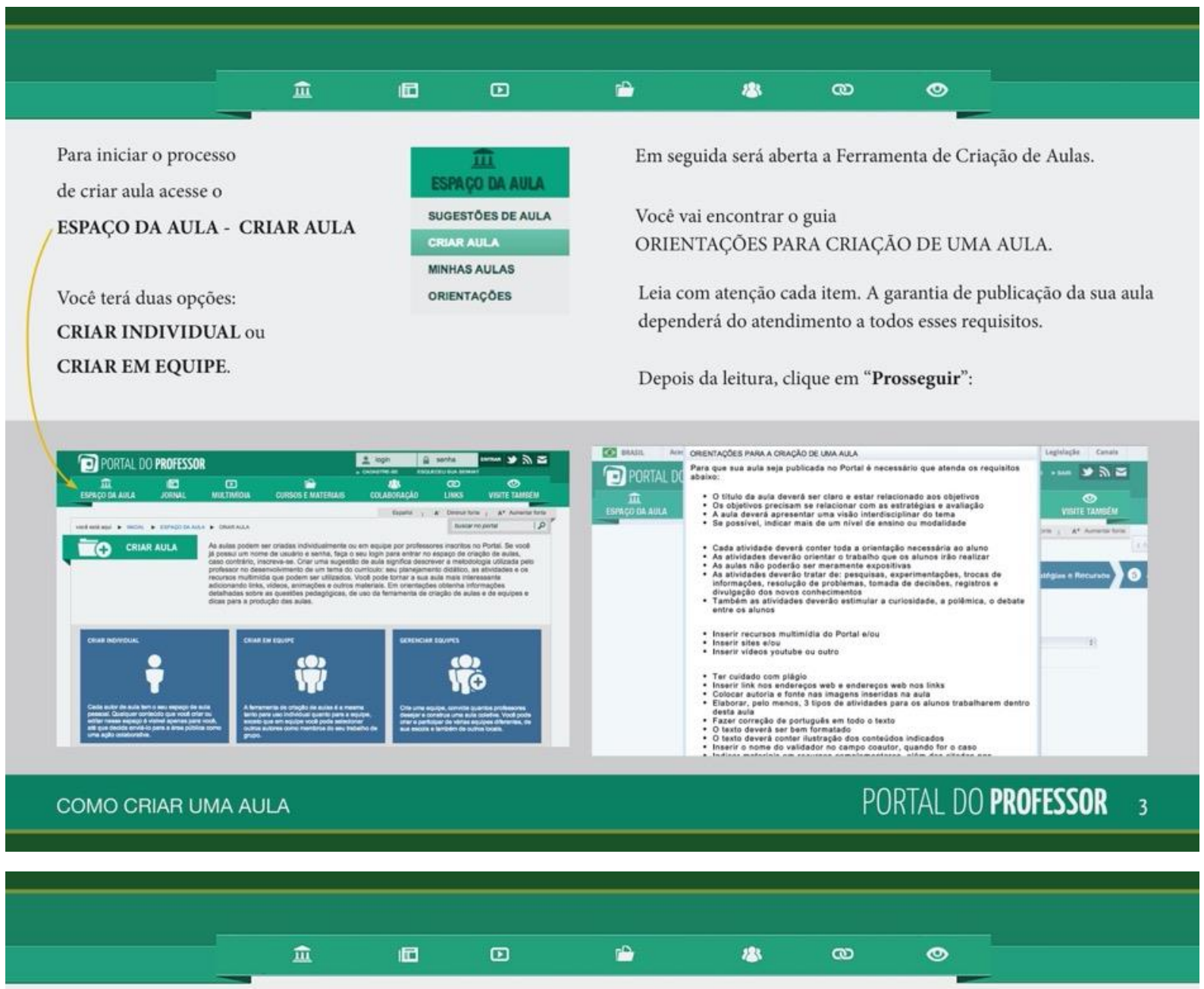

Siga os passos para o preenchimento da criação da aula:

1 - Autoria,

2 - Estrutura Curricular,

3 - Dados da Aula,

4 - Estratégias e Recursos,

5 - Avaliação.
Conforme você for preenchendo ou não as abas, elas mudarão de cor. Assim, temos 4 opções de cores:

Laranja: indica em que aba você está.

Azul: indica as abas não acessadas que ainda devem ser preenchidas. Verde: indica que todos os campos da aba foram preenchidos.

Vermelho: indica que um ou mais campos da aba não foram preenchidos.

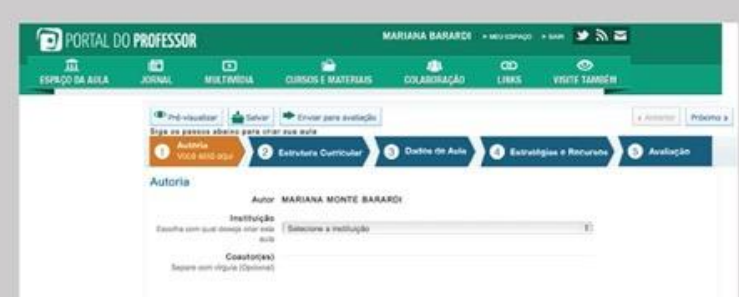

Você poderá clicar sobre as ABAS à medida que for preenchendo os campos ou clicar em Anterior ou Próximo.

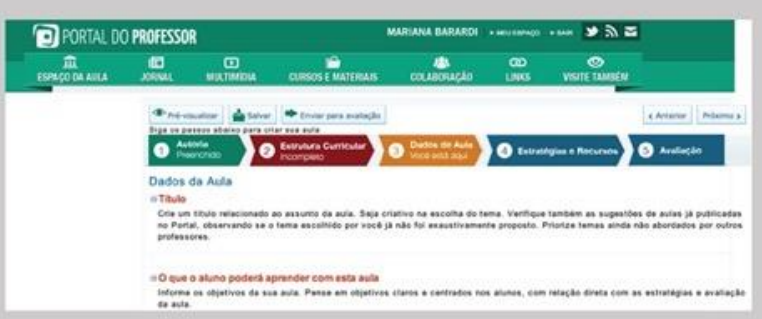



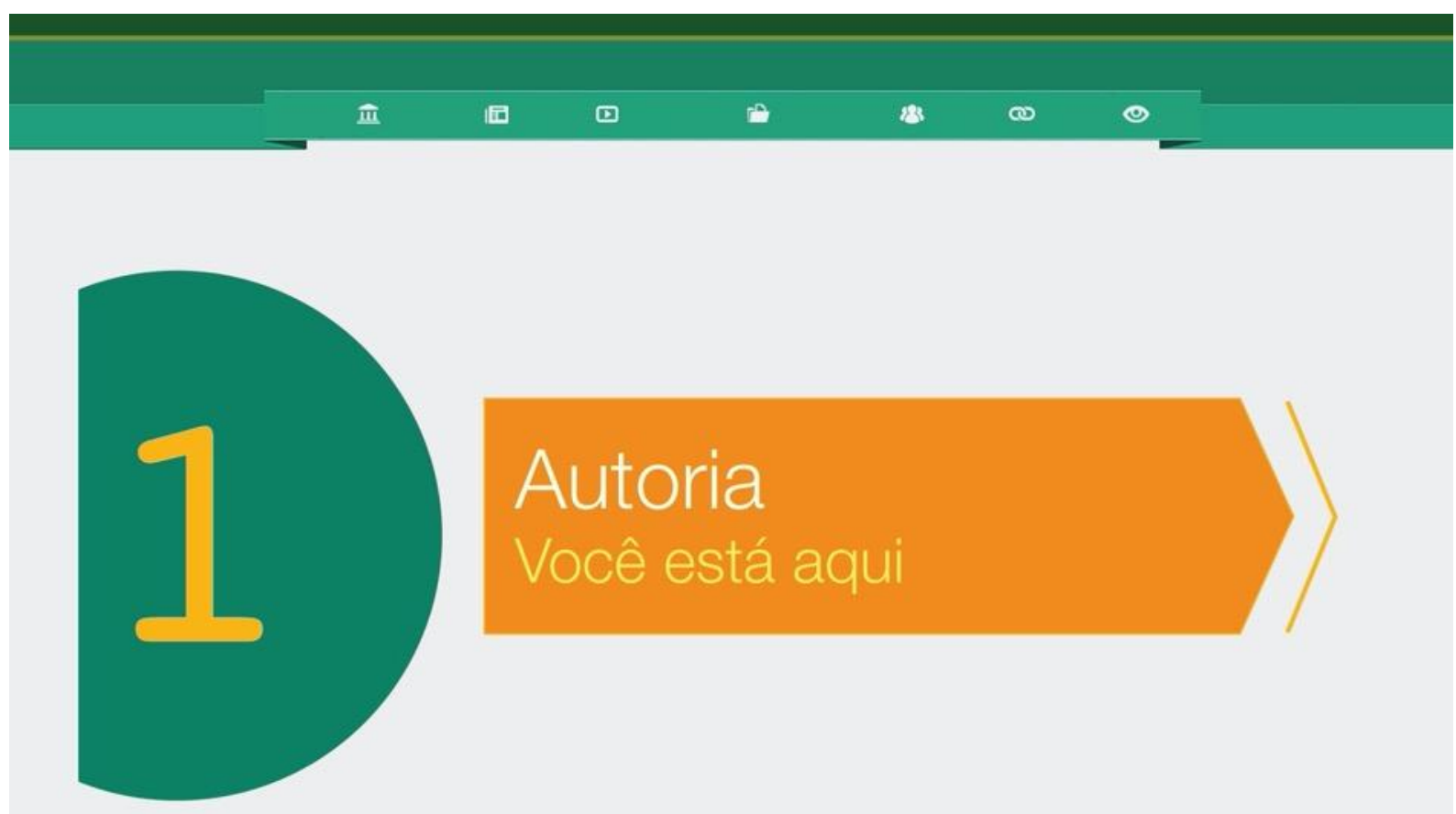

Autoria você está aqui

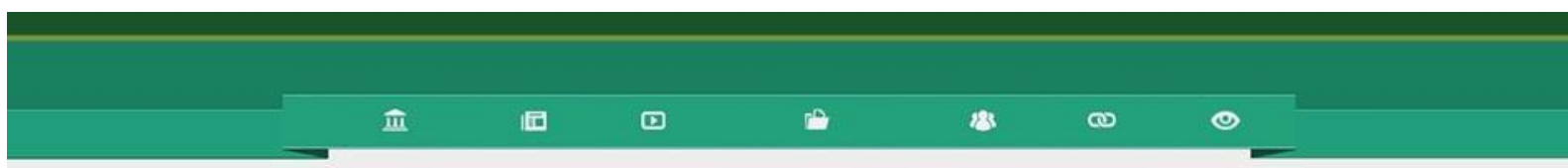

A página inicial para Criar Aula será sempre AUTORIA.

(1) Autor: nessa aba aparecerá automaticamente como AUTOR o nome do usuário que está logado no site.

2. Instituição: escolha a INSTITUIÇÃO com a qual deseja criar a aula.

Aparecerão como opçōes as instituiçōes que você escolheu ao se cadastrar no Portal.

3) Coautor (es): esse campo é opcional e deverá ser preenchido se você estiver criando a aula em parceria com outro professor.

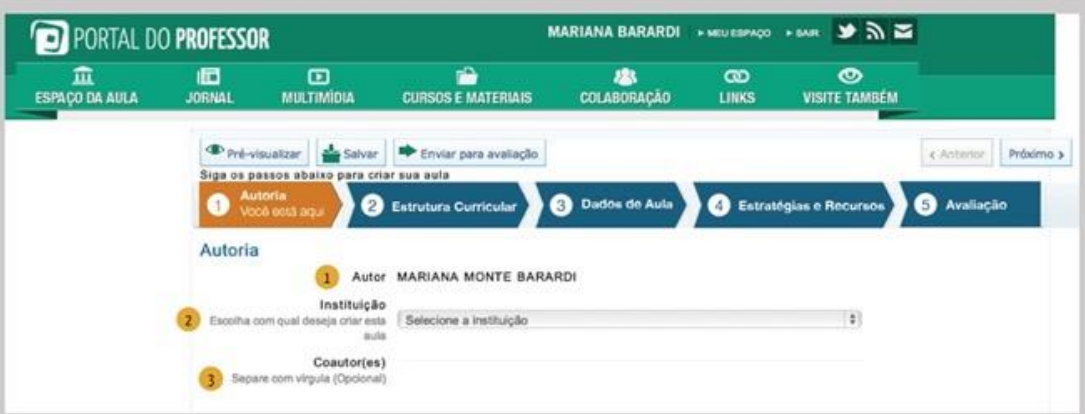



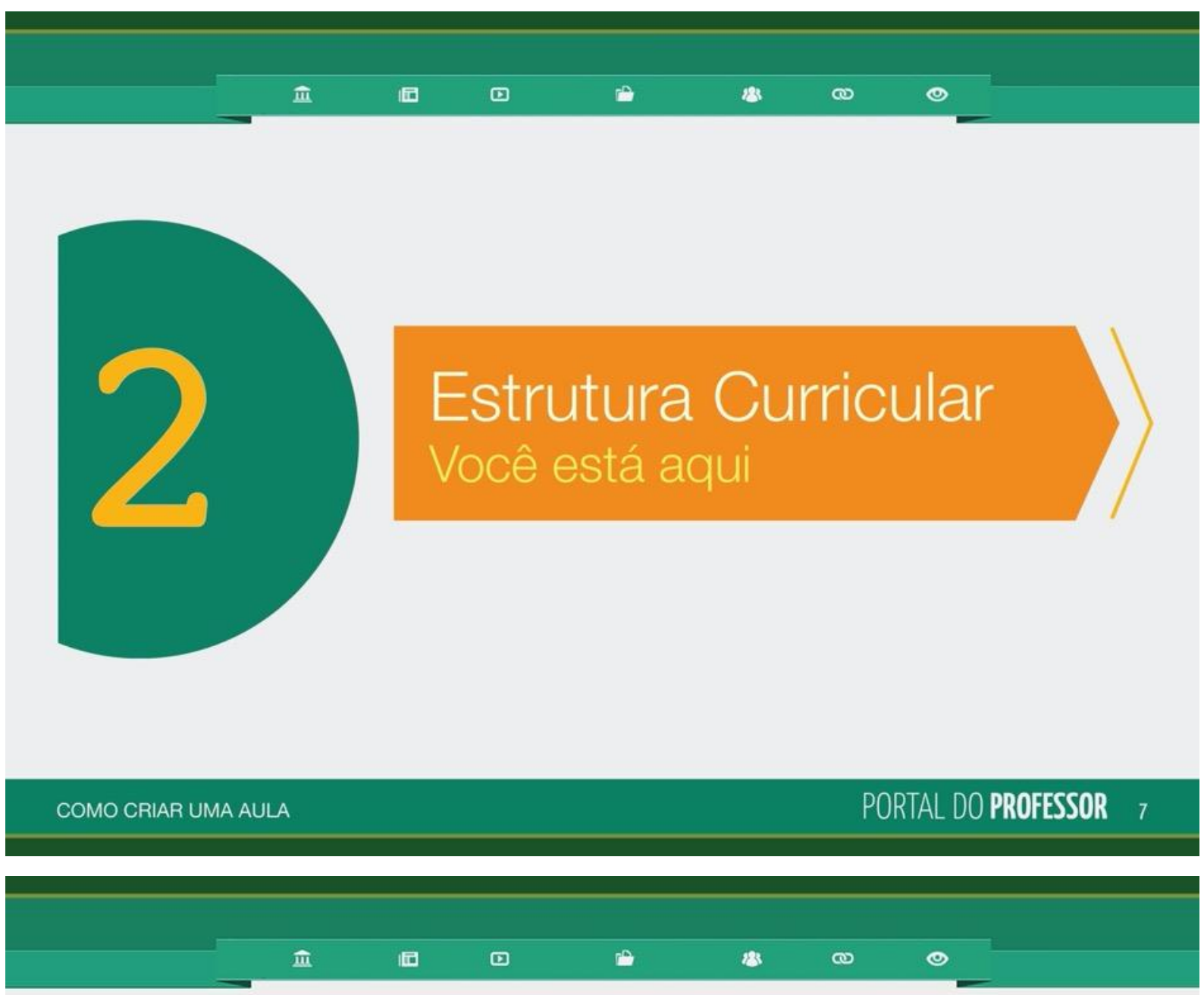

A próxima aba a ser preenchida é ESTRUTURA CURRICULAR

(1) Escolha o NÍVEL DE ENSINO ou a MODALIDADE para a qual sua aula é indicada.

(2) Escolha o COMPONENTE CURRICULAR da sua aula.

(3) Escolha o TEMA que está relacionado com sua aula e depois clique em "Adicionar".

(4) À medida que você for adicionando os temas, a ESTRUTURA CURRICULAR ficará listada no final da página.

5. É possível também remover temas relacionados clicando em "Remover"

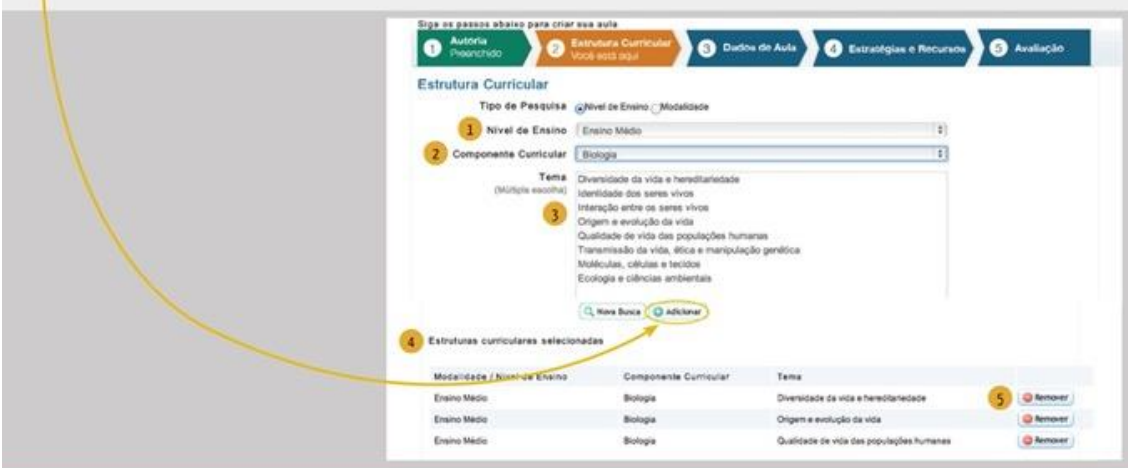



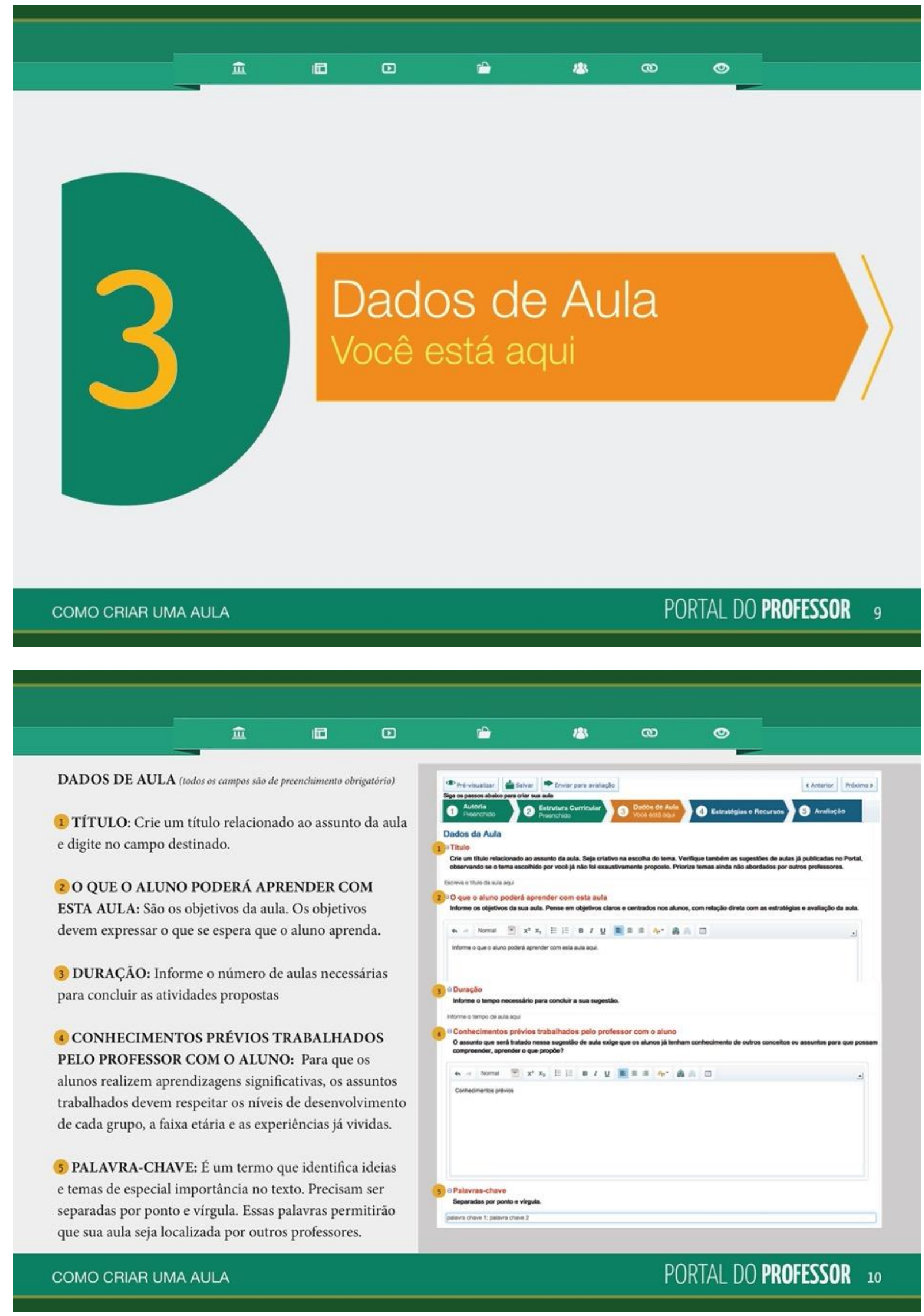

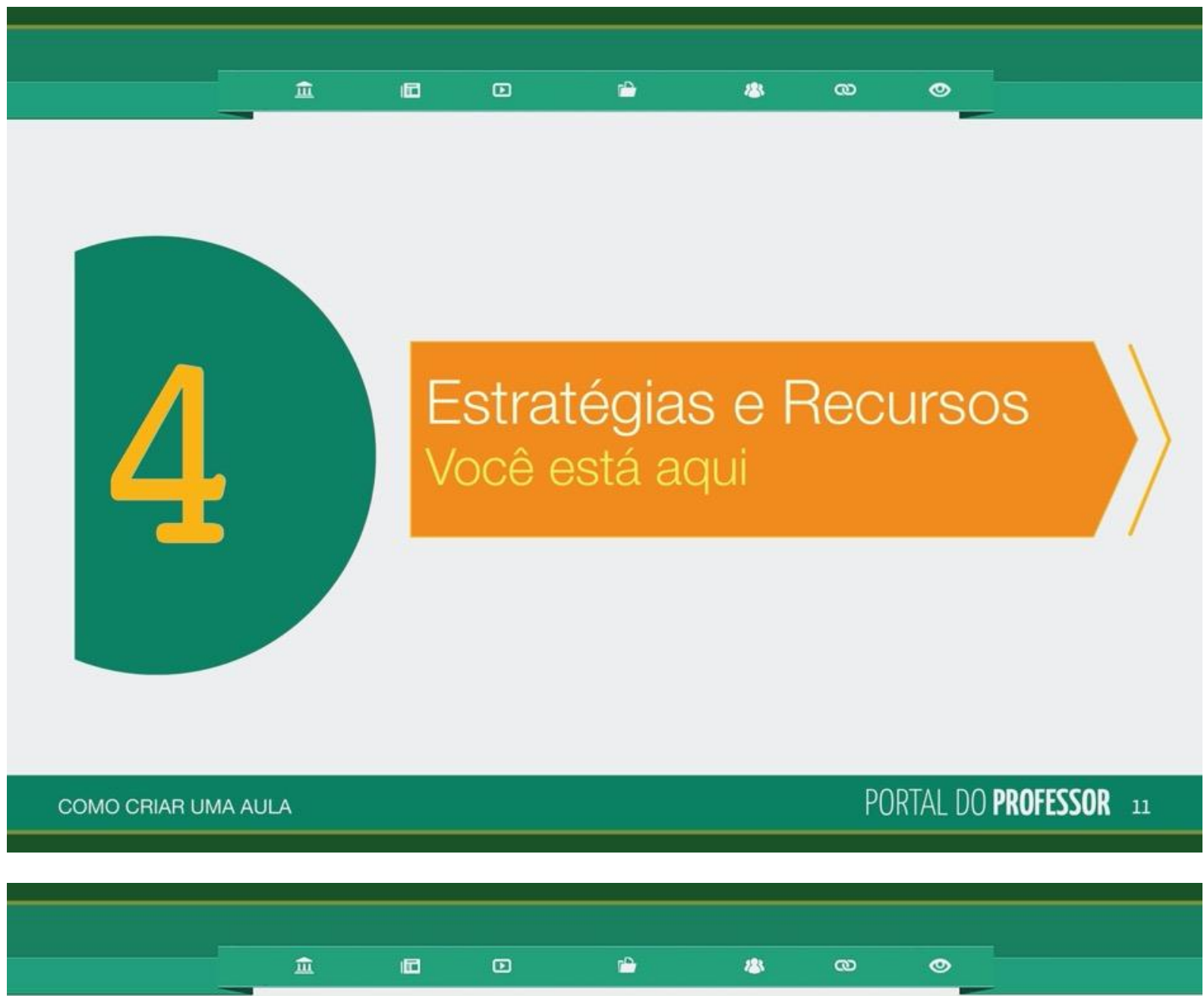

\section{ESTRATÉGIAS E RECURSOS}

- Defina o passo a passo da sua ideia de forma clara e objetiva;

- Preocupe-se em envolver os alunos mais como atores e agentes do processo do que como ouvintes;

- Inicie o primeiro passo com uma atividade criativa $\mathrm{e}$ motivadora;

- No desenvolvimento das atividades, estabeleça sempre uma relação clara entre o conteúdo e o dia a dia do estudante;

- Evite propor ao professor a introdução das atividades a partir de questionamentos e perguntas, pois essa não é uma forma

- Proponha atividades que possibilitem ao aluno debater, inovadora; construir, colaborar com os outros alunos, registrar e divulgar os novos conhecimentos.

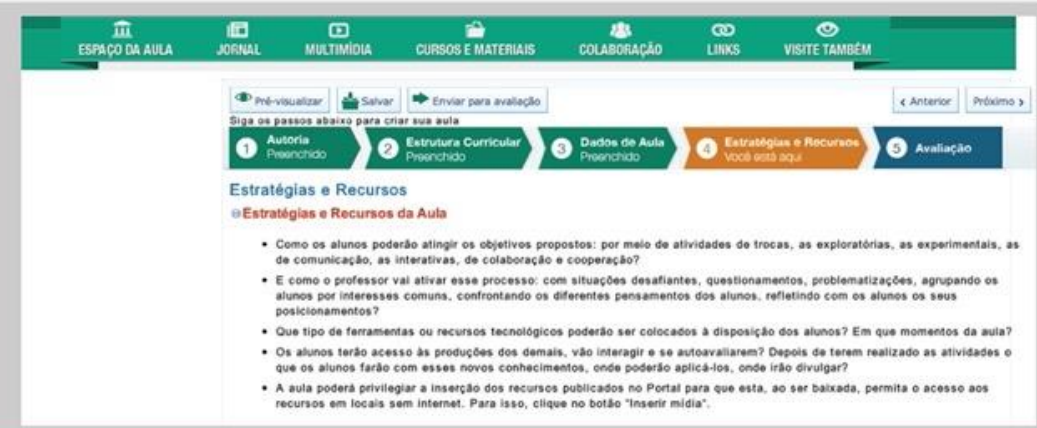

Mais importante que o trabalho do professor é a ATIVIDADE do aluno. Na sala de aula ou no laboratório quem trabalha é 0 aluno. $O$ professor apenas orienta a atividade do aluno. 

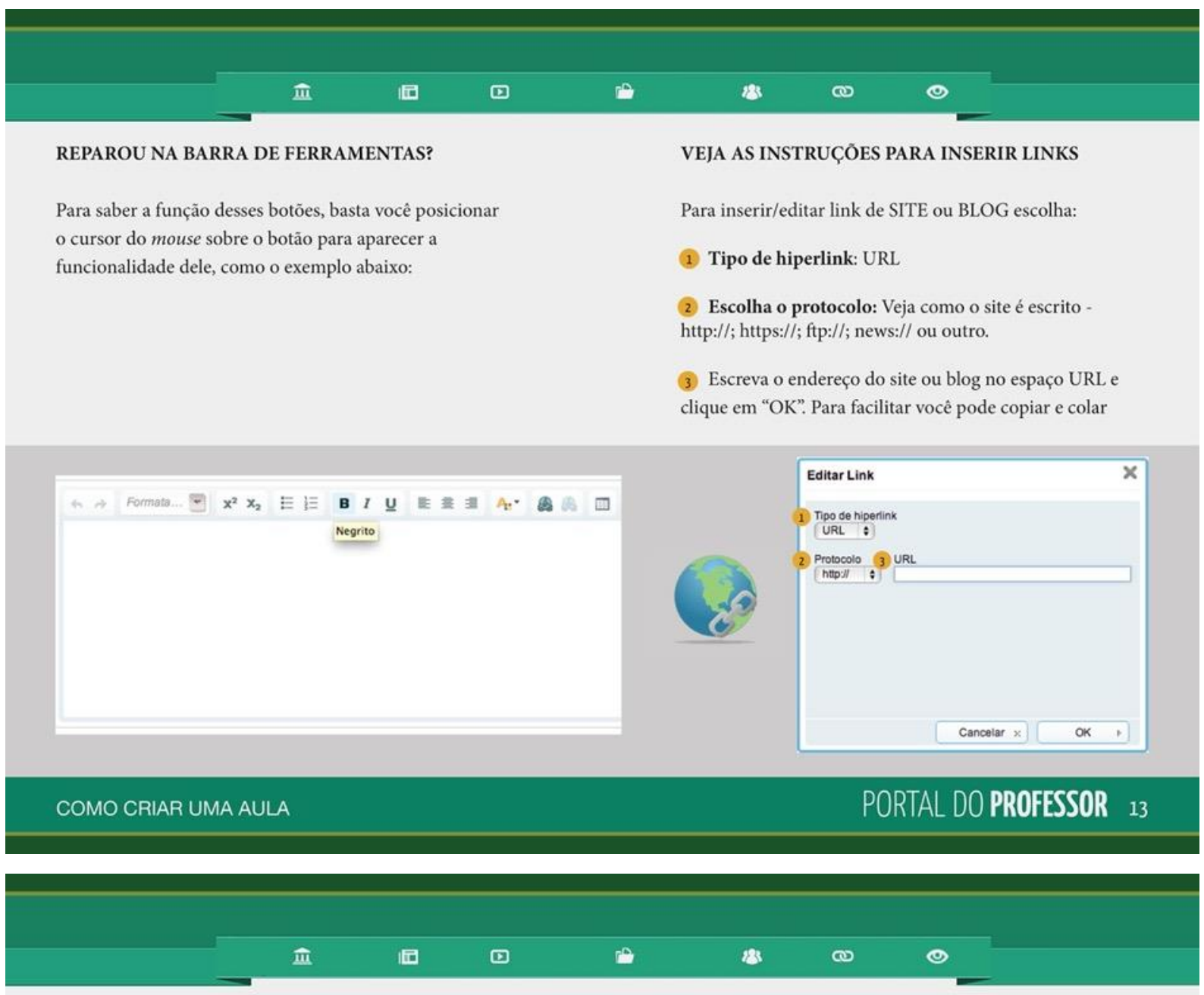

\section{RECURSOS DA BARRA DE FERRAMENTAS}

(1) REDIMENSIONAR essa ferramenta serve para ampliar (expandir) a tela onde você desenvolverá suas estratégias a fim de facilitar a visualização e formatação da aula. Para voltar à visualização original basta clicar outra vez em "Redimensionar".
2. INSERIR MÍDIA inclua em suas estratégias, recursos educacionais e imagens. A aula poderá privilegiar a inserção dos recursos disponibilizados no próprio Portal do Professor. $\mathrm{O}$ download da aula permitirá o acesso ao recurso em locais sem internet, além, é claro, de a aula ficar mais criativa e interessante.

Em “Inserir Mídia”, você terá duas opçōes: Recursos Educacionais e Imagens 

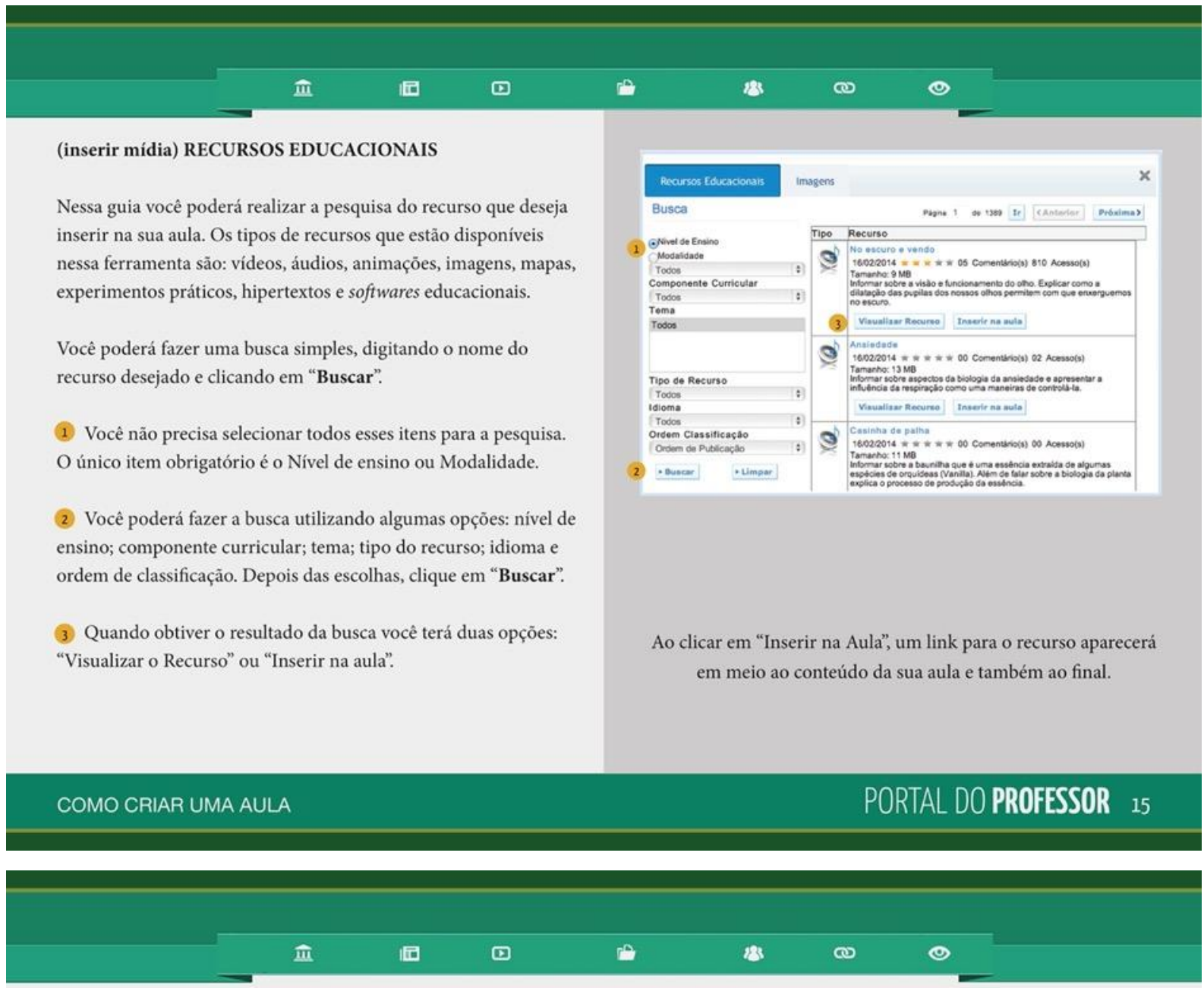

(inserir mídia) IMAGENS

Nessa guia, você poderá arquivar imagens que estejam salvas no seu computador.

\section{(1) INSERIR GALERIA} clique no primeiro ícone à esquerda da tela. Em seguida, aparecerá um quadro no qual você irá criar o nome de sua galeria e clicar em "OK".
Incluir as imagens do seu computador nas galerias:

2. Escolha a Galeria onde deseja que a imagem seja armazenada, clicando sobre ela.

3) Clique em "Envie uma nova imagem do seu computador".

(4) Aparecerá uma caixa com informações a serem preenchidas sobre a imagem: Título, Descrição e Autor.

5 Clique em "Selecionar arquivo". Encontre a imagem que deseja adicionar em seu computador. Clique sobre ela e em "Abrir".

6. Depois, clique em "Enviar"

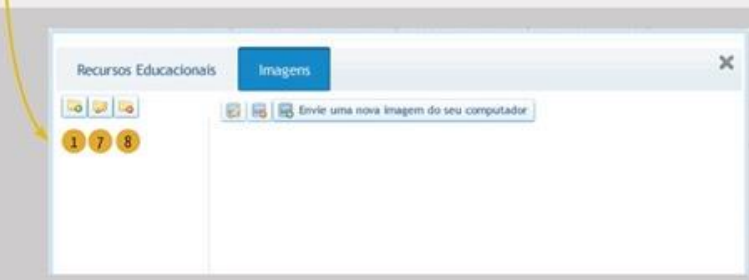

7 EDITAR GALERIA 8 EXCLUIR GALERIA

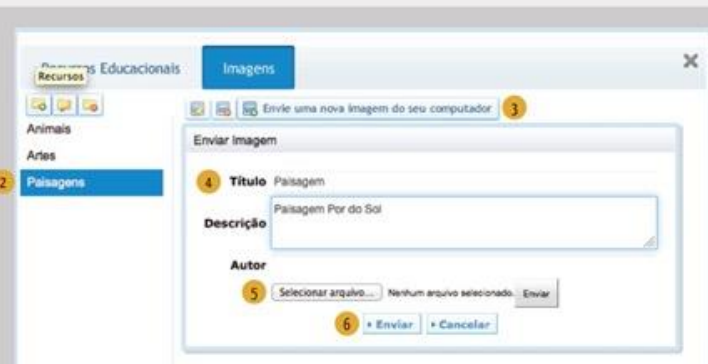

PORTAL DO PROFESSOR 16 

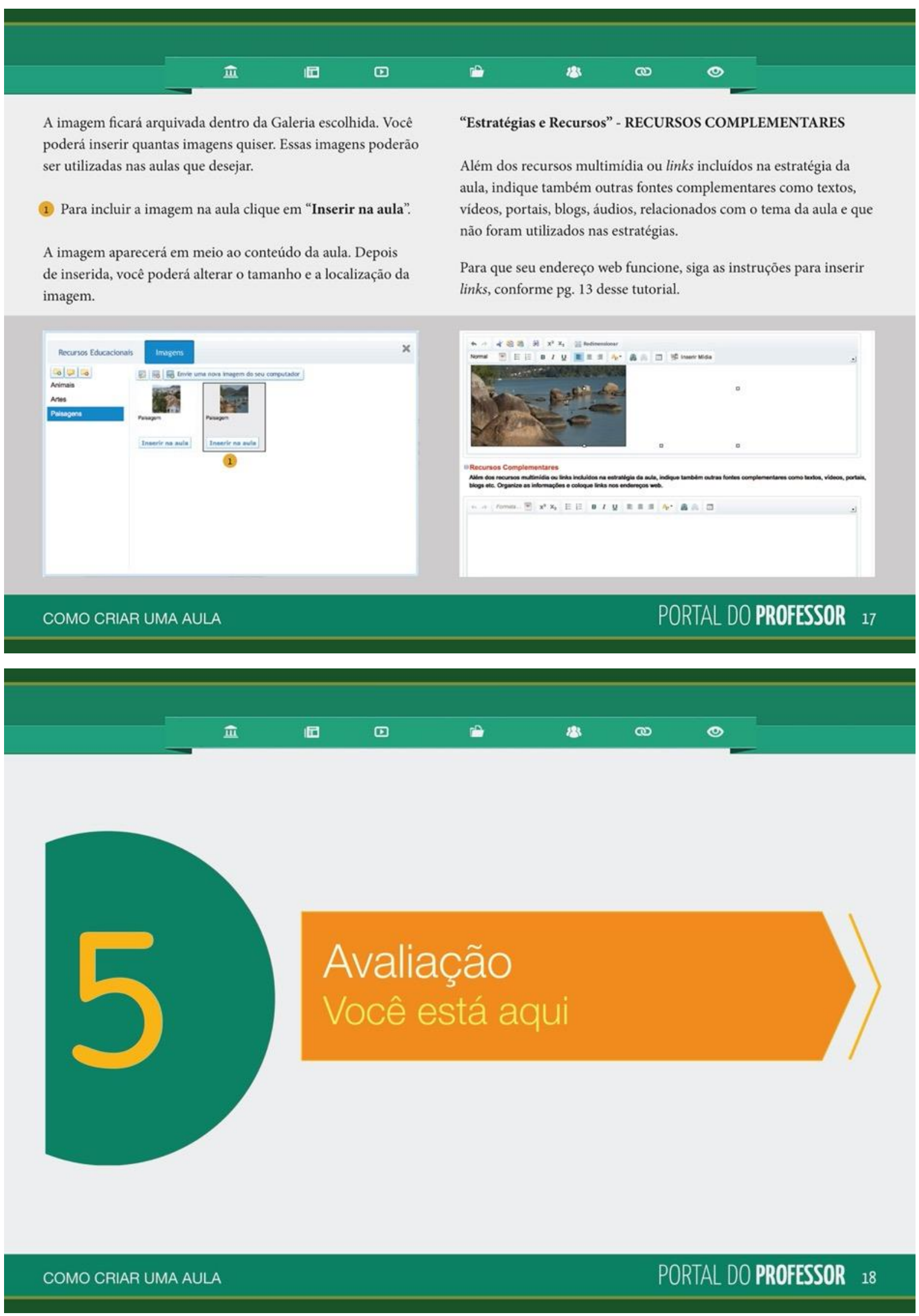

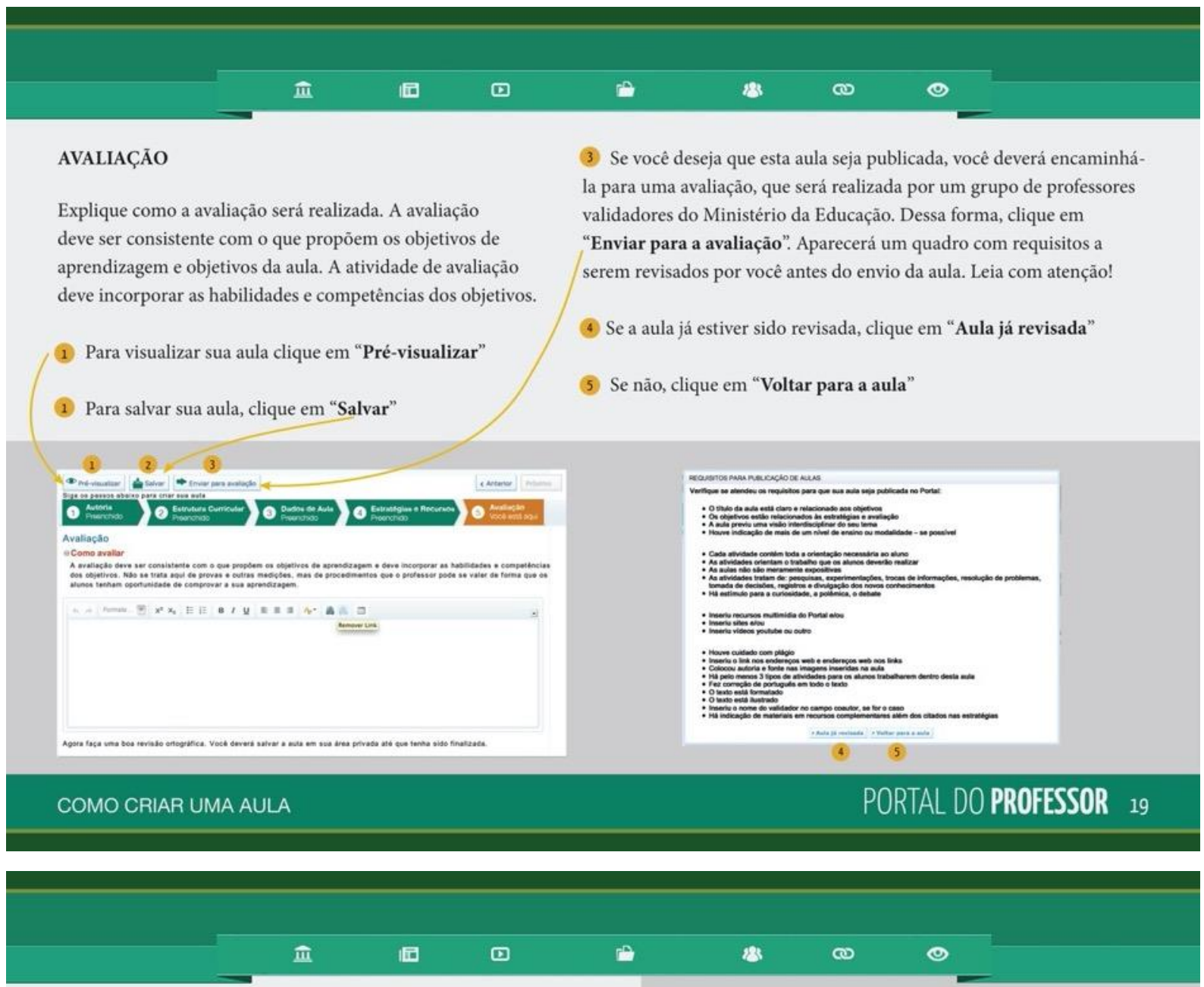

Ao clicar em "Aula já revisada", aparecerá o "TERMO DE ACEITE".

Observaçôes:

Leia com atenção e, caso concorde com o Termo, clique em "OK":

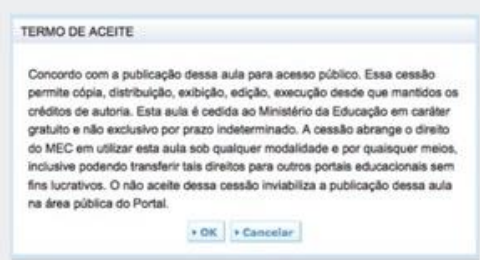

Esse símbolo significa que a aula está disponível apenas para você.

C Esse símbolo significa que a aula está publicada.

(2) Esse símbolo significa que a aula está com a Equipe de professores validadores para a avaliação.
Depois que a aula for enviada para a avaliação, ela não poderá ser alterada.

Quando enviada para a avaliação, sua aula ficará à disposição da equipe de Professores validadores para análise.

A equipe, após análise, terá duas opções:

1. Aprovar sua aula, dessa forma a aula será PUBLICADA no Portal do Professor.

2. Solicitar correções, assim a aula retornará para que você faça a sua edição conforme orientaçôes enviadas.

Ao corrigir a aula, você deverá encaminhá-la novamente para avaliação.

A aula só será publicada quando forem atendidos os requisitos mostrados anteriormente. 

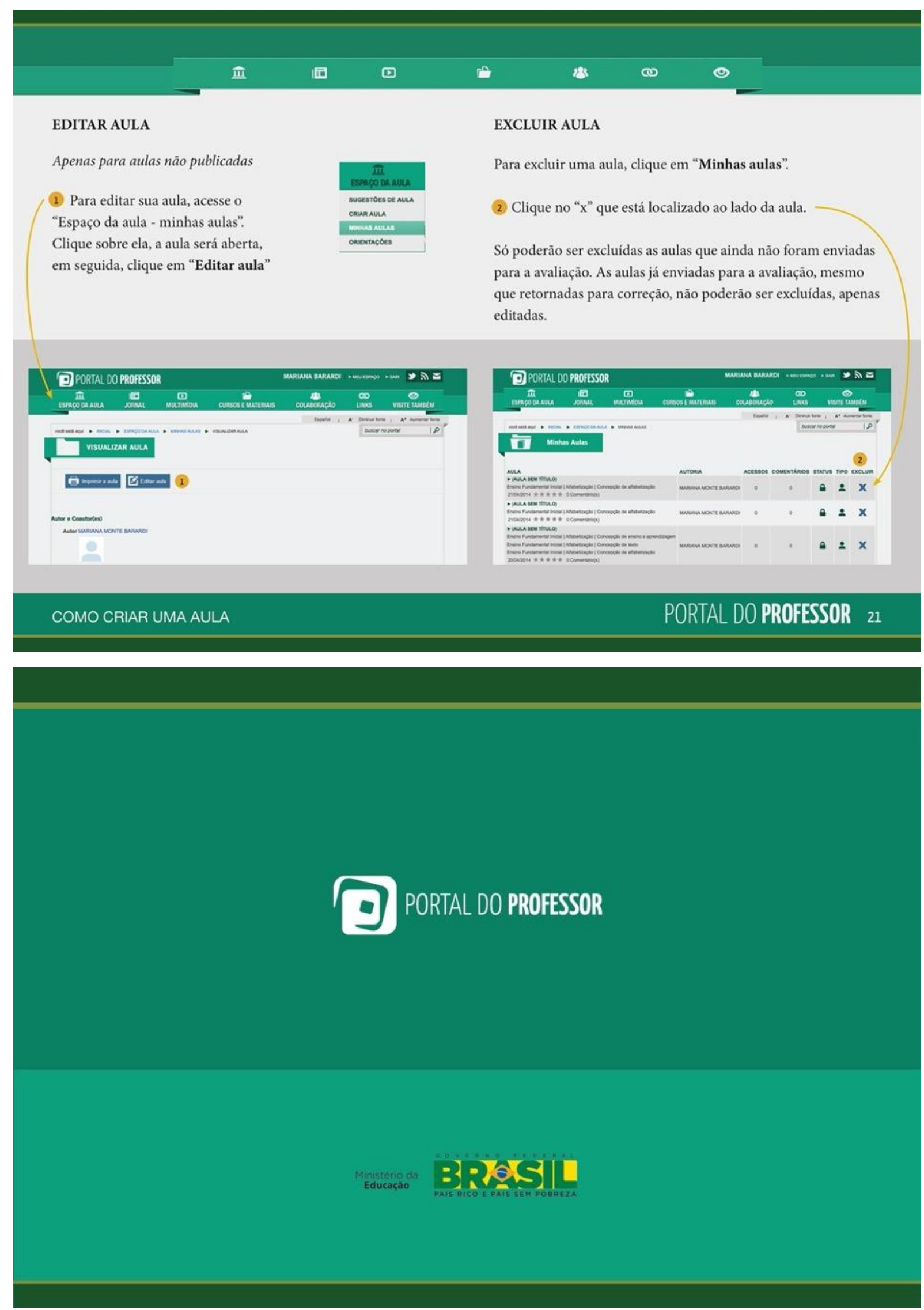
III Os planos de aula analisados 
VISUALIZAR AULA

\section{UCA - As potencialidades do conhecimento pela navegaçāo na Internet: uma visita ao Museu da Língua Portuguesa}

05/09/2011

Autor e Cosutor(es)

Autor: WALLESKA BERNARDINO SILVA

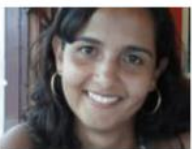

UBERLANDIA - MG ESC DE EDUCACAO BASICA

Coautor(es): Eliana Dias

\section{Estrutura Curricular}

MODALIDADE / NIVEL DE ENSINO

Ensino Fundamental Final

Ensino Fundamental Final

COMPONENTE CURRICULAR

TEMA

Ensino Fundamental Final

Lingua Portuguesa

Análise linguistica: processos de construção de significaçāo

Lingua Portuguesa

Análise linguistica: processos de construção de significaçąa

Análise linguistica: organização estrutural dos enunciados

\section{Dados da Aula}

O que o aluno poderá aprender com esta aula

- Visitar e informar-se virtualmente sobre o Museu da Língua Portuguesa

- Discutir a importância de se ter um site sobre o Museu da Lingua Portuguesa.

Duraçāo das atividades

3 aulas de 50 minutos cada.

Conhecimentos prévios trabalhados pelo professor com o aluno

- Gêneros diversos, como noticia, reportagem, folder, cartaz, dentre outros.

- Noçōes básicas de navegaçăo na internet.

Estratégias e recursos da aula

Estratégias:

- trabalho em duplas:
discussāo oral e coletivi

- produçāo de gêneros diversos para disseminação de informação.

Recursos:

- classmates UCA conectados à internet

- tutorial

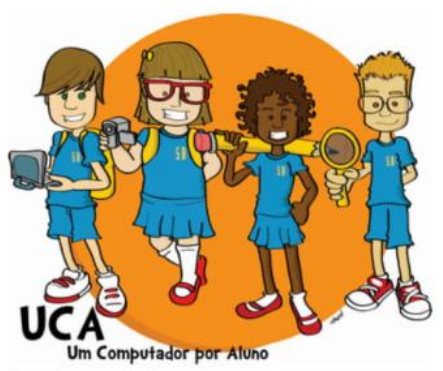

Aula 1

Atividade 1

A aula será desenvolvida a partir dos classmates dos alunos conectados à internet. O professor ao mesmo tempo estará acessando a web e sua navegação deverá ser exposta aos alunos por meio de um data show.

Os alunos receberão um tutorial e deverăo em duplas seguir as orientaçāes. As respostas ao tutorial deverāo ser digitadas no $K W$ ord e salvas.

tp://portaldoprofessor.mec.gov.br/fichaTecnicaAula.html?aula $=34853$ 


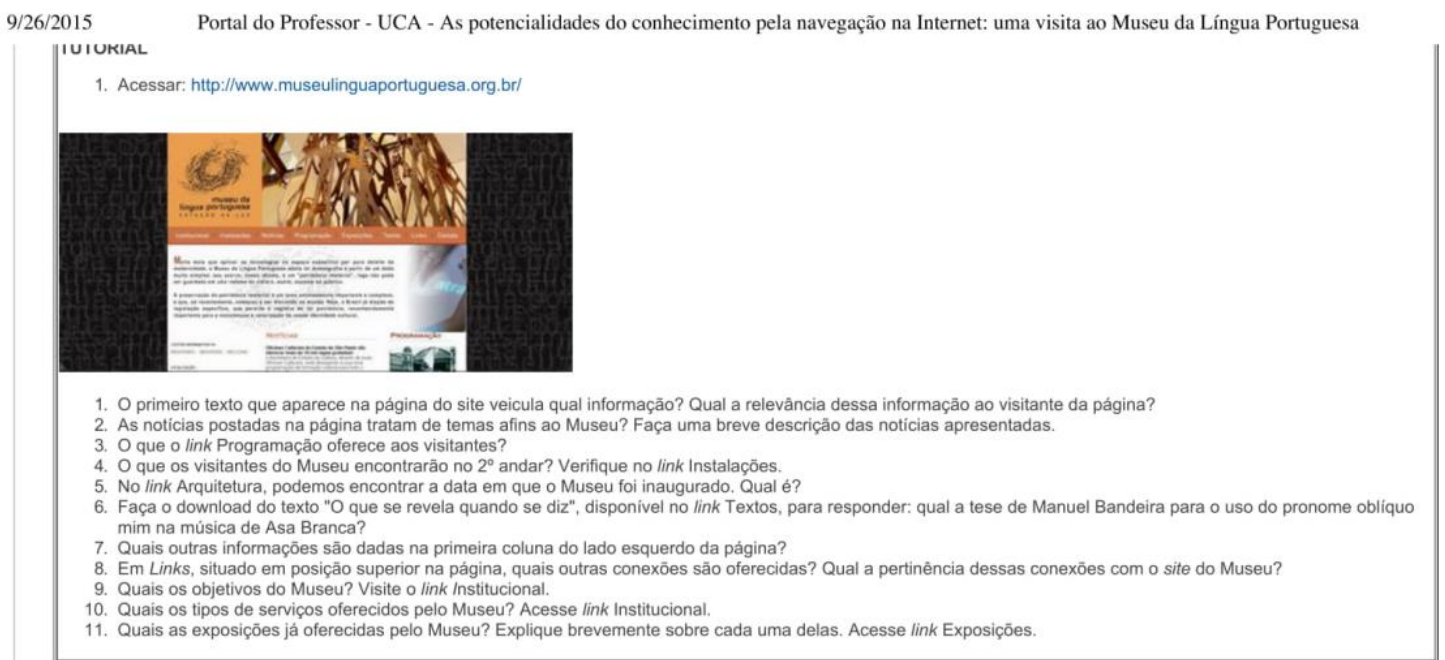

\section{Atividade 2}

Após resposta ao tutorial, os alunos enviarão os arquivos salvos aos colegas para que eles aprovem as respostas. Tendo, então, trocados os tutoriais, o professor, abrirả uma roda de discussão para conversar com os alunos sobre a importância do Museu da Língua Portuguesa e, especialmente, a importância de um site sobre esse Museu a fim de disseminar o acervo que nos e tấo caro: nossa lingua. Aproveitará a oportunidade para chamar a atençăo a algum item do tutorial que gerou dúvida ou que mereça maior

atenção.

Ả guisa de contribuição à conversa, o professor pedirá aos alunos para acessarem um vídeo - Beco das Palavras - que mostra parte das instalaçōes do Museu da Lingua Portuguesa:

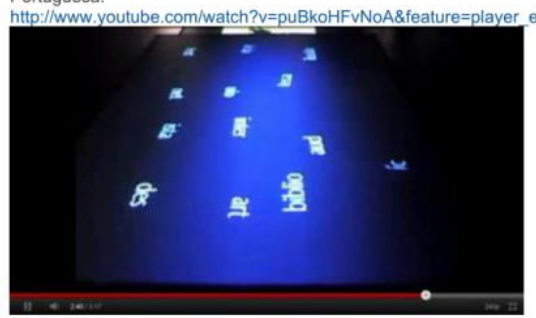

Atençăo: professor, destaque com os alunos o ponto forte do Museu: a tecnologia aplicada ao espaço expositivo. Isso atrai e desperta a atençăo dos visitantes. Conheça mais em:

hittp://idgnow. uol.com.brinternet/2006/08/04/idgnoticia.2006-08-04.1903374814/v

http://www.spbalada.com.br/museus/museu-da-lingua-portuguesa.htm/

http://biblio.crube.net?p=95

\section{Aula 2}

Depois de visitado 0 o site do Museu da Língua Portuguesa, os alunos terão a incumbência de divulgar o conhecimento adquirido por meio da exploraçăo da página da internet. Para tanto, o professor organizará os discentes em grupos que serão incitados a produzirem gêneros diversos que tratem de disseminar as informaçōes. Os gêneros a serem produzidos:

- Noticia

- Reportagem

- Cartazes

- Enquetes

- Propagandas

- Cançóes

Panfletos

Todos esses gêneros deverão circular pela comunidade escolar a fim de promover o conhecimento entre comunidade e Museu. Imagens podem ser utilizadas conforme gênero

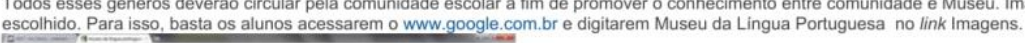

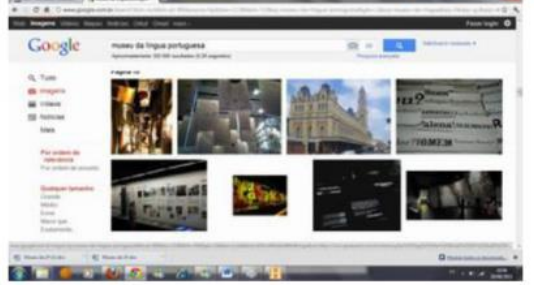

Essa atividade leva o aluno à reflexão sobre os objetivos do gênero discursivo com o qual trabalhará e sobre a necessidade de circulaçăo de informação atentando a uma esfera social especifica, com expectativas especificas.

Aula 3 
9/26/2015 Portal do Professor - UCA - As potencialidades do conhecimento pela navegação na Internet: uma visita ao Museu da Língua Portuguesa Atividade

professor poderá organizar com os alunos uma visita ao Museu da Lingua Portuguesa para apreciarem de perto o que viram e desfrutaram via internet. Aproveite, professor, a Part aproxima famila e escon

Recursos Complementares

Para apreciaçāo do professor:

ittp://www.youtube.com/watch?v=z6sNEQ5-iaY

Avaliaçāo

A avaliaçăo se dará pela realização do tutorial, pela participaçăo do aluno nas discussōes coletivas e, especialmente, pela produçăo de gêneros diversos que objetivam disseminar informaçōes sobre o Museu da Língua Portuguesa. 
VISUALIZAR AULA

\section{Entendendo as funçōes da linguagem}

\section{0/12/2009 \\ Autor e Cosutor(es)}

Autor: Júlia Maria Cerqueira

JUIZ DE FORA - MG Universidade Federal de Juiz de Fora

Coautor(es): Maria Cristina Weitzel Tavela

\section{Estrutura Curricular}

\begin{tabular}{|c|c|c|}
\hline $\begin{array}{l}\text { MODALIDADE / NIVEL DE } \\
\text { ENSINO }\end{array}$ & $\begin{array}{l}\text { COMPONENTE } \\
\text { CURRICULAR }\end{array}$ & TEMA \\
\hline $\begin{array}{l}\text { Educação de Jovens e Adultos - } 2^{\circ} \\
\text { ciclo }\end{array}$ & Lingua Portuguesa & Análise linguistica \\
\hline Ensino Fundamental Final & Lingua Portuguesa & Análise linguistica: processos de construçâo de significaçăo \\
\hline Ensino Médio & Lingua Portuguesa & $\begin{array}{l}\text { Aspectos cognitivo-conceituais: mundo, objetos, seres, fatos, fenômenos e suas inter- } \\
\text { relaçóes }\end{array}$ \\
\hline
\end{tabular}

\section{Dados da Aula}

O que o aluno poderá aprender com esta aula

Compreender as funçōes da linguagem: referencial (ou denotativa), conotativa (ou apelativa), fática, emotiva (ou expressiva), poética e metalinguistica. Duração das atividades

4 aulas de 50 minutos

Conhecimentos prévios trabalhados pelo professor com o aluno

Habilidades básicas de leitura

Estratégias e recursos da aula

ETAPA 1: CONHECENDO A FUNÇĀo REFERENCIAL (OU DENOTATIVA) E A FUNÇÃo CONATIVA (OU APELATIVA)

Peça aos alunos que leiam os dois textos que se seguem. O primeiro, da jornalista Poliani Castelo Branco, refere-se ao inicio da História do voto em nossa pátria, quando ela ainda nem se chamava Brasil. O segundo diz respeito à importância do voto, trata-se de uma campanha organizada pelo Tribunal Superior Eleitoral (TSE).

A história do voto no Brasil começou 32 anos após Cabral ter desembarcado no Pais. Foi no dia 23 de janeiro de 1532 que os moradores da primeira vila fundada na colônia portuguesa - São Vicente, em São Paulo - foram às urnas para eleger o Conselho Municipal.

Disponivel em: http://www. adital.org. br/site/noticia2.asp?lang=PT\&cod=13981

Acesso em: Dezembro de 2009.
TEXTO 2

SE, MAS PRóXIMAS ELEIÇ̄̃ES,

VOCE NÃ̃ ESCOLHER

OS MELHORES CANDIDATOS

A PREFEITO E VEREADOR.

SUA CIDADE VAI

PERDER 4 ANOS.

E 4 ANOS É MUITO TEMPO.

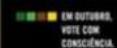

\section{포오}

Em seguida, leve os alunos a refletir sobre as diferentes intençōes desses textos. O primeiro é objetivo e informa sem julgamentos. O segundo, porém, procura influenciar o

Como ele o faz? Coloque esta questão para seus alunos.

Leve-os a perceber que o primeiro avisa sobre uma possivel sançăo, caso năo se vote nos "melhores candidatos a prefeito e a vereador".

Que sançẩo seria esta?

A resposta é que a cidade perderia quatro anos - o que é muito tempo, complementa enfaticamente.

O primeiro texto, portanto, tem uma funçấo referencial ou denotativa, ele procura traduzir objetivamente a realidade ao emissor, sem julgamentos. 0 segundo tem uma funçăo conativa ou apelativa, procurando influenciar o comportamento do receptor ou persuadi-lo de algo.
Abaixo, seguem outros exemplos de propaganda eleitoral, como opçăo ou complemento do assunto: 


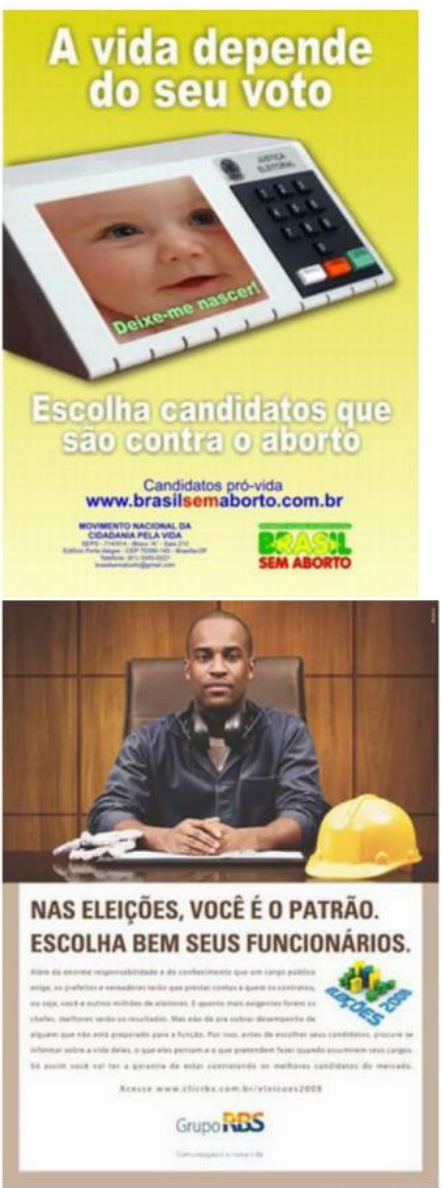

ETAPA 2: CONHECENDO A FUNÇĀO FÁTICA

PROFESSOR: Peça aos alunos que leiam as figuras que se seguem:

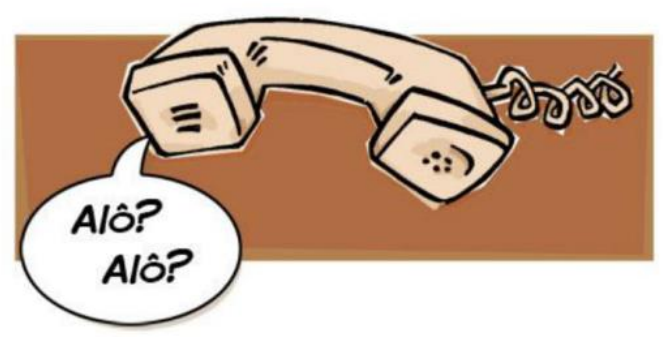




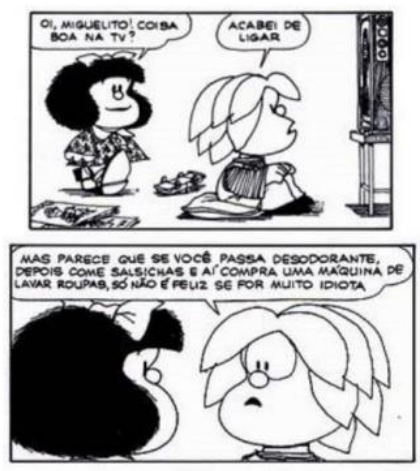

Em seguida, pergunte a eles:

Qual seria a intençăo dessa frase?

PROFESSOR: Explique a seus alunos que, no primeiro caso, o emissor deseja verificar se o canal de comunicação está funcionando, além de iniciar a comunicação. Já no

segundo, o emissor (Mafalda) quer iniciar uma comunicaçăo

Em ambas as situaçōes: testando o canal de comunicaçăa (o telefone) ou iniciando o contato (através da saudação), estamos falando da função fática.

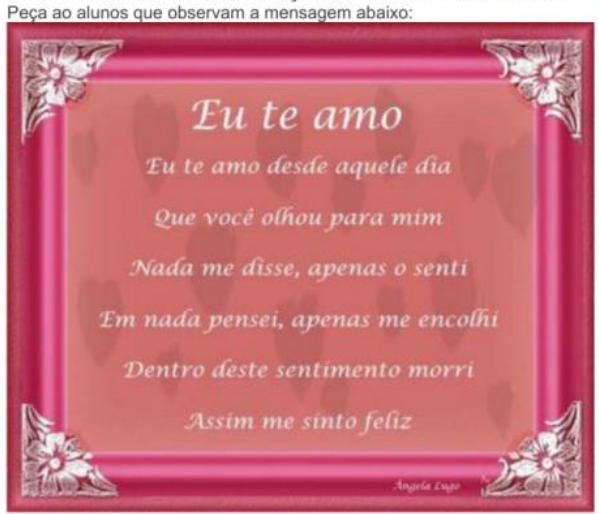

Pergunte aos alunos:

se texto foi escrito?

Para quem ele foi escrito?

Discuta com os alunos que se trata de uma mensagem centralizada no emissor, isto é, na $1^{1 a}$ pessoa (eu), expressando sua emoçăo e/ou sentimentos. Por esse motivo, denominada função emotiva ou ex pressiva. E uma função muito usada em biografias, memórias, poesias liricas e cartas de amor.

Peca aos

VVVVVVVVVV
VVVVVVVVVE
VVVVVVVVEL
VVVVVVVE LO
VVVVVVE LOC
VVVVVE LOC I
VVVVE LOC I D
VVVELOC I DA
VVELOCIDAC
VELOC IDADE




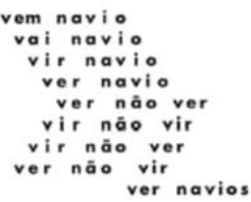

Pergunte a seus alunos o que há de especial nos dois textos acima? Chame-os a atençăo para a diagramaçâo das palavras, isto é, para sua disposiçăo no espaço. Destaque a

Leve-os a perceber a forma criativa com que a lingua foi usada: isto é, com uma disposição especial da mensagem na folha e com a exploração da sonoridade, causada pela repetiçăo das consoantes " $v$ " $e$ " $n$ "

A função poética é, portanto, a linguagem das obras literárias, principalmente das poesias, em que as palavras săo escolhidas e dispostas de maneira que se tornem singulares.

ETAPA 4: CONHECENDO A FUNÇ̄̄O METALINGUISTICA

Peça que os alunos leiam a definição abaixo. Trata-se de uma das definiçōes do vocábulo "voto":

[Doto lat. votu, 'promessa'.]

8. Maneira de expressar a vontade ou opinião num ato eleit oral ou numa assembleia.

Explique a seus alunos que toda vez que utilizamos a linguagem para definir, esclarecer ou ensinar algo a alguém, utilizaremos a funçấ metalingüistica, isto é, a linguagem para

Avaliaçāo

PROFESSOR: Para verificar se os alunos conseguiram internalizar os conceitos trabalhados, pesquise vários exemplos de trechos de textos, entre eles propagandas, noticias, poemas, entre outros, e proponha um exercicio de identificação das funçōes de linguagem predominantes nesses trechos. 
$8 / 22 / 2017$

BRASI Serviços Barra GovBr

VISUALIZAR AULA

Coesão textual: o pronome na construção do texto

18/12/2009

Autor e Coautor(es)

Autor: LAZUITA GORETTI DE OLIVEIRA

imagem do usuário

UBERLANDIA - MG ESC DE EDUCACAO BASICA

Coautor(es): Eliana Dias

Estrutura Curricular

MODALIDADE / NIVEL DE ENSINO

Educaçẫo de Jovens e Adultos $-2^{\circ}$ ciclo

COMPONENTE CURRICULAR

Ensino Fundamental Final
TEMA

Linguagem escrita: leitura e produçāo de textos

Análise linguistica: modos de organizaçăo dos discursos

Dados da Aula

O que o aluno poderá aprender com esta aula

- reconhecer e empregar pronomes como elementos coesivos responsáveis pela reativação do referente em um texto;

- conhecer as diversas formas de referência pronominal associadas às diferentes possibilidades de se dirigir a interlocutores em diferentes contextos de comunicaçăo:

- reconhecer diferenças entre a norma padrão e o uso não- padrão de pronomes em textos diversos:

- saber que a escolha pronominal está condicionada a fatores, tais como: a natureza do texto, o grau de formalidade ou informalidade, os objetivos da interaçăo, a natureza da modalidade, se oral ou escrita.

Duraçāo das atividades

4 aulas de 50 minutos

Conhecimentos prévios trabalhados pelo professor com o aluno

- conhecer pronomes pessoais (pessoais, obliquos e de tratamento), possessivos, demonstrativos, indefinidos e interrogativos;

- conhecer os termos essenciais da oraçấo: sujeito/predicado.

Estratégias e recursos da aula

- reproduçẫo de tirinhas veiculadas na internet:

- utilização do laboratório de informática.

Aula 1

Atividade

Importante: Professor, Coesāo textual trata-se da ligação, da conexâo entre as palavras de um texto, por meio de elementos formais, que assinalam o vinculo entre os seus componentes. A coesão textual pode se estabelecer por meio de diversos elementos lingüisticos. Dentre esses elementos, os pronomes assumem grande relevância, principalmente, pelo fato de ser por meio deles que se faz a retomada do referente, isto é, aquilo a que or Para retomar o tema a ser estudado com os alunos, o professor deverá levá-los ao laboratório de informática, para que, em dupla, pesquisem sobre pronomes. Disponiveis nos sites:

http://pt.wikipedia.org/wiki/Pronome

http://www.infoescola.com/portugues/pronomes/

Aula 2

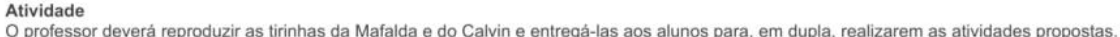

Tirinha 1 

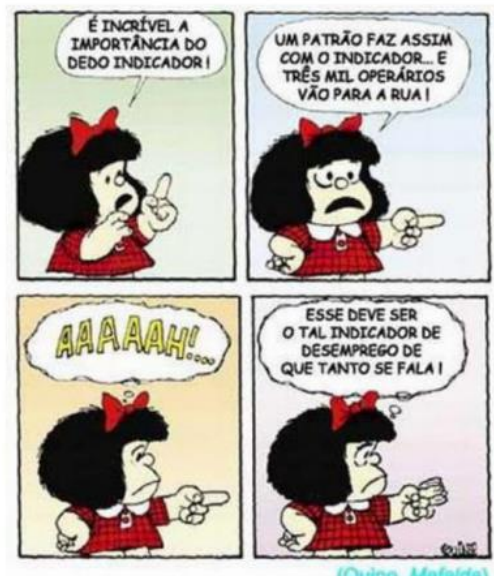

Disponivel em:

(Ouino. Mafalda)

Ditp://www planetaeducacao com.br/novo/imagens/artigos/enem 02.jpg

1. Sobre a tirinha 1 da Mafalda:

. Identifique o pronome demonstrativo usado na tirinha.

b. Qual é o referente desse pronome no texto?

. De acordo com norma padrāo, como deve ser o emprego dos pronomes demonstrativos em

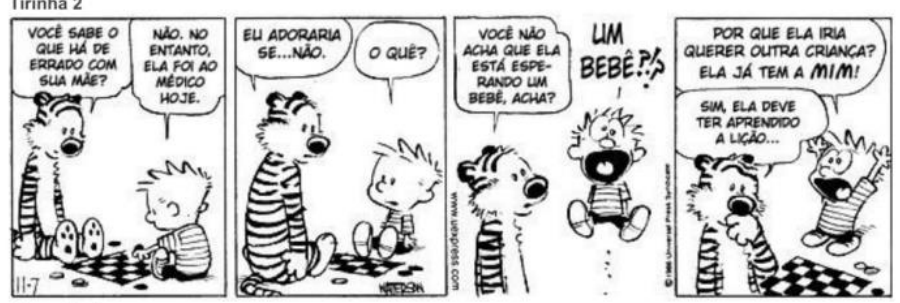

Disponivel em:
http://apatossauros.files.wordpress.com/2007/10/calvinharodotira354.gif

Sobre a tirinha 2 do Calvin:

a. Identifique os pronomes empregados na tirinha.

b. Observe a fala do Calvin no primeiro quadrinho: a quem se refere o pronome ela?

c. Pronome possessivo é o tipo de pronome que faz uma referência às pessoas do discurso indicando uma relaçāo de posse. Identifique o pronome possessivo empregado na

d. Observe a fala de Harodo no primeiro quadrinho;

"Você sabe o que há de errado com sua mãe?

elo pode estar se referindo a um objeto que já foi citado e que por isso não precisa ser repetido, ou a um objeto que sequer foi nesse caso, ele tem funçāo adjetiva.

Qual dessa situaçōes ocorre na fala de Haroldo? Explique.

d. Observa a fala do Calvin no último quadrinho.

Sabendo que, de acordo com a norma padrāo, só se usa o pronome eu q uando exercer a fun çăo sintática de s ujeito de um verbo e o pronome mim quando na função sintática de complemento verbal ou nominal, explique o emprego do pronome mim na fala de Calvin.
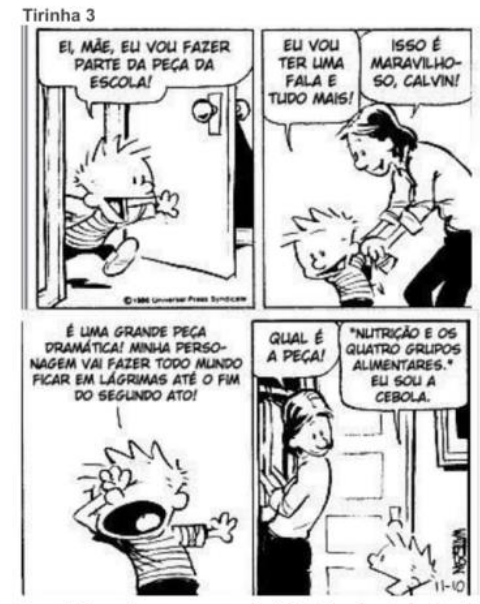


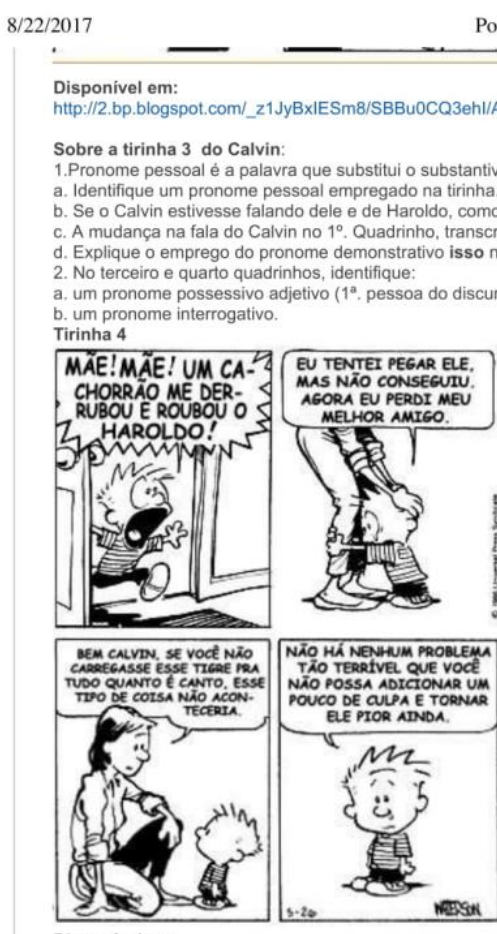

Disponivel em:

http://cronicasurbanas.files.wordpress.com/2009/04/calvin-e-a-culpa.jpg

Sobre a tirinha 4 do Calvin:

1. Os pronomes pessoais se dividem em retos, que funcionam como sujeito, e obliquos que funcionam como objeto, isto é, complemento de verbos.

a. Identifique um pronome obliquo na fala de Calvin, no primeiro quadrinho.

b. No segundo quadrinho, hả o emprego de um pronome obliquo que nāo está de acordo com a norma padrāo. Identifique-o e reescreva a frase corrigindo-a.

. Considerando a situação comunicativa, pode-se dizer que o emprego do pronome ele no segundo quadrinho está inadequada? Rescrva a frase, corrigindo -a.

3. Observe a fala de Calvin, no terceiro quadrinho e responda:

a. A quem se refere o pronome você? Como esse pronome se classifica?

b. Como se classifica o pronome nenhum? Por quế?

c. A quem se refere o pronome ele?

4. Quando o pronome se refere a um termo já presente no texto, dizemos que tem função anafórica. Exemplifique essa afirmaçăo com passagens da tirinha.

Aula 3

O professor deverá fazer a correçāo oral das atividades, aproveitando o momento para tirar dividas dos alunos.

Aula 4

Atividade

O professor deverá reproduzir para os alunos o conto, "Partilha" , de Rubem Braga e solicitar os alunos que, após a leitura do texto, respondam às questōes propostas na

sequência.

Texto:

Partilha

Os irmãos se separam e então um diz assim:

"Você fique comara que quiser, eu nẵ fậ questão de nada: mas se você năo se incomoda, eu queria levar essa rede Você nắo gosta muito de rede, quem sempre deitava nela

O relógio da parede eu estou acostumado com ele, mas você preci sa mais de relógio do que eu. O armário grande do quarto e essa mesa de canela e essa tralha de cozinha, e o guarda-comida também. Tudo isso é seu. O retrato de nossa i rmã você fica com ele também: deixa comigo o de mãe, pois foi a mim que ela deu: você tínha aquele dela de chapéu, e você perdeu. O tinteiro de pai é seu; você escreve mais carta; e até que escreve bonito, você sabe que eu li sua carta para Júlia.

Essas linhas e chumbadas, o puçá e a tarrafa, tudo fica sendo seu; você năo nem empatar um anzol, de maneira que para mim é mais fácil arrumar outro aparelho no dia que eu quiser pescar.

Agora, tem uma coisa, o canivete. Pensei que você tivesse jogado fora, mas ontem estava na sua gaveta e hoje eu acho que está no seu bolso, meu irmão.

Ah, isso eu faço questão, me dê esse canivete. O fogăo e as cadeiras, a estante e as prateleiras, os dois vasos de enfeite, esse quadro e essa gaiola com a coleira e 0 alçapẫo, tudo é seu; mas o canivete é meu. Aliás, essa gaiola fui eu que fiz com esse canivete me ajudando. Você não sabe lidar com canivete, você na sua vida inteira nunca oube descascar uma laranja direito, mas para outras coisas você é bom. Eu sei que ele está no seu bolso.

Eu estou dizendo a vocế que tudo que tem nesta casa, menos o retrato de mãe - a rede mesmo eu não faço questão, embora eu goste mais de rede e fui sempre eu que

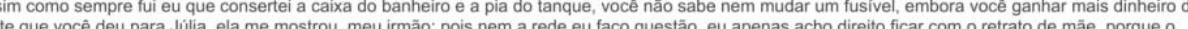
outro você perdeu.

Me dê esse canivete, meu irmão. Eu quero guardar ele como recordaçăo. Quem me perguntar por que eu gosto tanto desse canivete, eu vou dizer: é porque é lembrança do neu irmão. Eu vou dizer que é lembrança do meu irmão que nunca soube lidar com um canivete, assim como de repente não soube mais lidar com seu próprio irmão. Ou então me dá vergonha de contar e eu digo assim: esse canivete é lembrança de um homem bêbado que antigamente era meu amigo, como se fosse um irmão. Eu estarei dizendo a

verdade, porque eu acho que você nunca foi meu irmăo.
Eu sou mais velho que você, sou mais velho pouca coisa, mas sou mais velho, de maneira que posso dar conselho: você nunca mais na sua vida, nunca mais puxe canivete para um homem; canivete é serventia de homem, mas é arma de menino, meu irmấo. Quando você estiver contrariado com um homem, você dê tío nele com sua garrucha; ode até matar à traiçâo; nós todos nascemos para morer. Demaneira

presta, mas para outras coisas vocế é bom

Agora fique sossegado, tudo que tem at é seu. Adeus, e seja feliz, meu irmāo.

Fonte: BRAGA, Rubem. In Elenco de cronistas modernos. Rio de Janeiro, José Olympio, 1994.

Texto disponivel em:
http://meudiarioembranco.blogspot.com/2008/01/all-i-really-want-is-some-patience.html

Sobre o texto:

Com os conhecimentos que você adquiriu sobre o emprego dos pronomes, após ler o texto, responda:

1. Em relaçāo à situação de comunicaçăo, ao grau de intimidade entre os falantes, o pronome de tratamento você foi adequadamente empregado?

2. Observe esta passagem do texto: 
"Ah, isso eu faço questão, me dê esse canivete. O fogăo e as cadeiras, a estante e as prateleiras, os dois vasos de enfeite, esse quadro e essa gaiola com a coleira e o alçapăo, udo é seu; mas o caniveté mel, Alys

a. Observando os pronomes demonstrativos, pode-se dizer que os objetos mencionados ( canivete, quadro, gaiola, coleira, etc) estāo próximos a quem?

(a) considerando que os objetos estejam distantes do falante.

Nesse texto, aparecem vários pronomes. Escolha dois exemplos de cada tipo e explique o emprego de cada um deles.

4. O emprego de vários tipos de pronomes, principalmente possessivos e demonstrativos relacionam-se com o assunto do conto - partiliha familiar de bens? Justifique sua resposta.

Avaliação

Professor, para avaliaçăo de um tópico tẫo complexo como o emprego dos pronomes na construçẫo do texto, nẫo se deve levar em conta somente as regras prescritas pela norma padraa. Faz-se necessário apresentar aos alunos diversas situaçāes de uso que vão determinar critérios de correção que se relacionam com a adequação de uma forma a uma dada situação. Certamente, o mais importante é a ampliação do repertório linguistico do aluno, apresentando-Ihe outros usos que fogem do seu universo comunicativo, mas que estâo presentes em alguns discursos. 


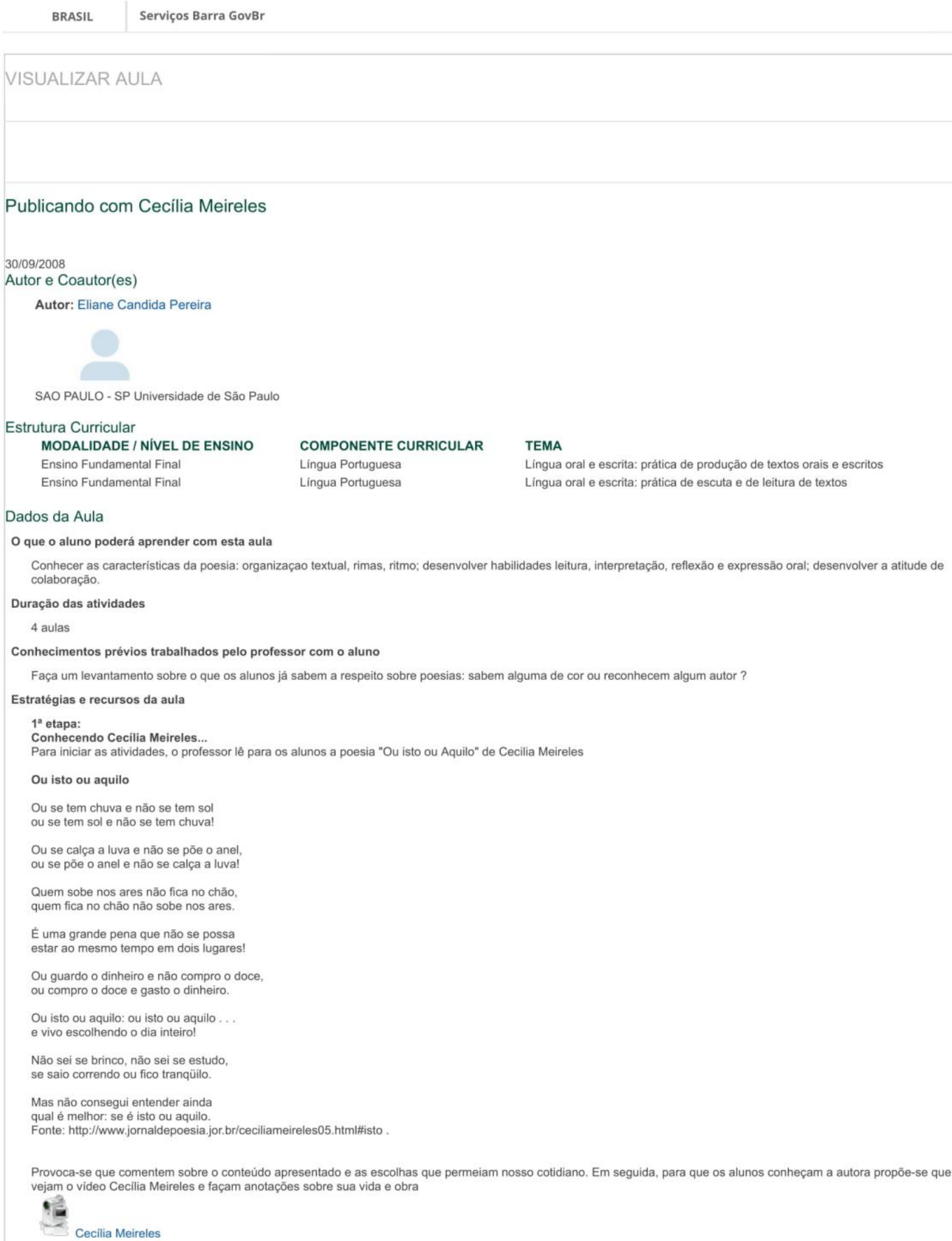

SAO PAULO - SP Universidade de São Paulo

\section{Estrutura Curricular}

MODALIDADE / NIVEL DE ENSINO

Ensino Fundamental Final

COMPONENTE CURRICULAR

Lingua Portuguesa

Ensino Fundamental Final

Lingua oral e escrita: prática de produção de textos orais e escritos Língua oral e escrita: prática de escuta e de leitura de textos

Dados da Aula

O que o aluno poderá aprender com esta aula

Conhecer as características da poesia: organizaçao textual, rimas, ritmo; desenvolver habilidades leitura, interpretação, reflexão e expressão oral; desenvolver a atitude de colaboraçẫo.

Duração das atividades

4 aulas

Conhecimentos prévios trabalhados pelo professor com o aluno

Faça um levantamento sobre o que os alunos jả sabem a respeito sobre poesias: sabem alguma de cor ou reconhecem algum autor ?

Estratégias e recursos da aula

$1^{\text {a }}$ etapa:

.

Para iniciar as atividades, o professor lê para os alunos a poesia "Ou isto ou Aquilo" de Cecilia Meireles

Ou isto ou aquilo

Ou se tem chuva e nāo se tem sol

ou se tem sol e não se tem chuval

Ou se calça a luva e não se põe o anel,

ou se põe o anel e não se calça a luva!

Quem sobe nos ares não fica no chẫo.

quem fica no chão não sobe nos ares.

É uma grande pena que não se possa

estar ao mesmo tempo em dois lugares

Ou guardo o dinheiro e não compro o doce,

ou compro o doce e gasto o dinheiro.

Ou isto ou aquilo: ou isto ou aquilo . .

e vivo escolhendo o dia inteiro!

Não sei se brinco, năo sei se estudo,

se saio correndo ou fico tranqüilo.

Mas nāo consegui entender ainda

qual é melhor: se é isto ou aquilo.

onte: http://www.jornaldepoesia.jor.br/ceciliameireles05.html\#isto .

Provoca-se que comentem sobre o conteúdo apresentado e as escolhas que permeiam nosso cotidiano. Em seguida, para que os alunos conheçam a autora propōe-se que vejam o video Cecilia Meireles e façam anotaç̄es sobre sua vida e obra

?를

Cecilia Meireles

É preciso instigá- los a conhecer outras poesias de Cecilia Meireles. Para isso faz-se a organizaçăo de grupos de trabalho para que pesquisem outras poesias da autora na 
biblioteca da escola ou na biblioteca pública. Na aula seguinte, organiza-se uma roda de leitura com as poesias encontradas pelos alunos.

$2^{\mathrm{a}}$ etapa:

Escrevendo com Cecilia Meireles.

Para exploração de ritmo e rimas, pode-se propor que façam trocas de algumas palavras, sem que a poesia perca sua musicalidade, realizando assim, novas produções a partir das obras de Cecilia Meireles. Para provocar maiores reflexōes sobre as caracteristicas do gênero, solicitar também que cada grupo escolha uma poesia e reescreva seu conteúdo em prosa.

$3^{\mathrm{a}}$ etapa:

Lendo com Cecilia Meireles.

Para divulgar as obras de Cecilia Meireles, bem como as poesias produzidas a partir delas, os alunos devem ser convidados a gravarem um livro falado. Audiobook, audiolivro ou livro falado é uma "gravaç̃o dos conteńdos de um livro lidos em voz alta". Para tal, basta que façam a leitura das poesias selecionadas usando um microfone e o gravador de som dos equipamentos dos laboratórios de informática da escola.

Abra o gravador, apontando para Menu Iniciar > Programas > Acessórios > Entretenimento > Gravador de Som:

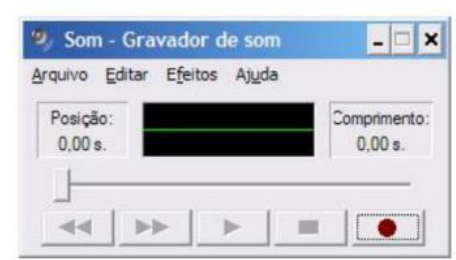

O professor deve provocar a revisão do material produzido, lembrando-os que o ritmo será essencial durante a leitura. Pode-se sugerir que coloquem fundo musical na gravaçăo. Os arquivos podem ser salvos como (nome do arquivo).MP3, (nome do arquivo).WVM, (nome do arquivo).WAV

\section{$4^{a}$ etapa:}

Publicando com Cecilia Meireles.

Para publicar os livros falados dos alunos na internet basta usar sites de hospedagem de conteúdo como

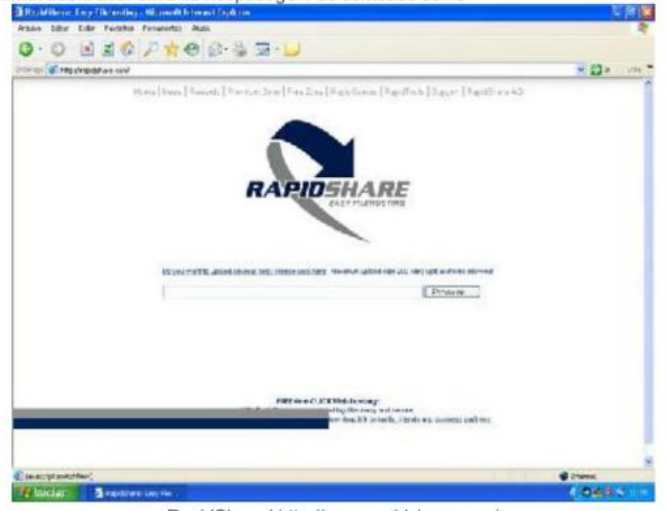

RapidShared http://www.rapidshare.com/

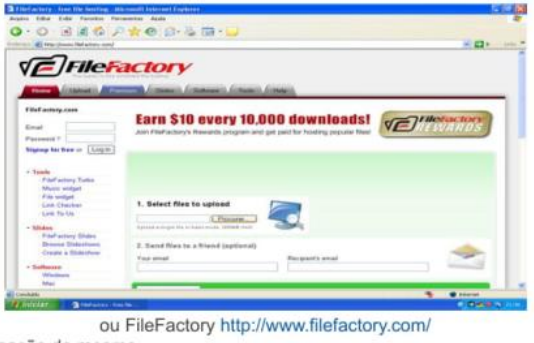

armazenando o conteúdo on line com um link para divulgaçāo do mesmo.

É possivel também preparar um blog com os alunos, disponibilizando os textos escritos e os arquivos em áudio. Para isso há serviços gratuitos na Internet, muito simples de usar, como por exemplo: https://www.blogger.com

\section{Recursos Educacionais \\ NOME TIPO \\ Cecilia Meireles Video}

Recursos Complementares

Para conhecer livros falados: http://www.bibvirt.futuro.usp.br/sons/livros_falados; Para saber mais sobre PodCast: http://www.podbrasil.com.br/oquee/comofazer.php 
Avaliação

É necessário observar se durante as etapas os alunos reconhecem as caracteristicas do gênero, bem como, promover a auto-avaliação e a avaliação entre os membros dos grupos sobre a produçāo do livro falado colaborativamente. 
VISUALIZAR AULA

\section{Debate deliberativo sobre Bullying}

\section{4/09/2009 \\ Autor e Cosutor(es)}

Autor: ROSÂNGELA FERREIRA LUZ

Aimagem do usuário

DOURADOS - MS EM PROFa CLORI BENEDETTI DE FREITAS

\section{Estrutura Curricular}

$\begin{array}{lll}\text { MODALIDADE / NIVEL DE ENSINO } & \text { COMPONENTE CURRICULAR } & \text { TEMA } \\ \text { Ensino Fundamental Final } & \text { Pluralidade Cultural } & \text { Direitos humanos, direitos de cidadania e pluralidade } \\ \text { Ensino Fundamental Final } & \text { Lingua Portuguesa } & \text { Lingua oral e escrita: prática de escuta e de leitura de textos }\end{array}$

\section{Dados da Aula}

O que o aluno poderá aprender com esta aula

O aluno aprenderá a organizar e analisar os dados de pesquisa, selecionando artigos e depoimentos que sejam úteis para a apresentação do trabalho em forma de debate. Sua pesquisa deverá ser salva no blog individual criado pelo aluno para difundir o tema na rede, para discussăo e reflexão, aprenderá também a elaborar o discurso oral e escrito, usando expressōes adequadas a um debate deliberativo, apresentando argumentos que embasem a posição tomada e com sugestôes coerentes para serem colocadas em funcionamento dentro da comunidade escolar, táo logo findem as atividades em sala sobre o assunto. Aprenderá a perceber $e$ utilizar a concordância verbal e nominal para

Duração das atividades

10 aulas de 50 minutos.

Conhecimentos prévios trabalhados pelo professor com o aluno

Pesquisa nos sites indicados sobre o tema:

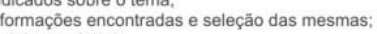

Organização do material para debate

Abertura do blog;

para apresentar o tema;

texto com sugestōes para erradicar o bullying:

Estratégias e recursos da aula

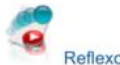

Esta animação será mostrada com o intuito de levantar a questão da exclusão social e, em seus comentários posteriores, perceberão que acontece por causa de preconceitos cimentados em nossa formação humana.

Em seguida trabalharāo com a webquest planejada por mim e publicada no Docs.google, colada abaixo e imagens que serāo mostradas no data show sobre situaçōes de bullying no ambiente escolar.

Veja abaixo como foi idealizado a webques:

Lingua Portuguesa

Elaborada por: Professora Rosângela Ferreira Luz

rosangelaluz@terra.com.br

Introdução | Tarefa | Processo | Avaliação | Conclusão | Créditos | Página do Professor

Introdução

D aluno lerá a webquest publicada ou digitada no word:

(fala destinada ao aluno) Vocế sofre bullying em sua escola e năo sabe o que fazer para se livrar desta vergonha e raiva que passa todo dia com alguém zombando de você? 0 que deve fazer?

Convivemos com o bullying sem perceber, seja como a vitima que sofre silenciosamente, como espectadores ou os causadores deste sofrimento...Como vitima você pode chegar ao suicidio e como bullier você nẫo pode imaginar a reação de sua vitima e como espectador pode se traumatizar..

Beste momento, os alunos visitarão os sites para definir o tema:

\section{A Tarefa}

Pesquisar nos sites recomendados o que é bullying.

Discutir as caracteristicas do bullying, informando às outras turmas como erradicar o mal em nossa escola, apresentar sugestōes para que as vitimas tenham direito e năo medo

Vocêsunciar. escola.

O Processo

Instruçōes para os alunos:

Prá começar a aquecer, vocês deverão organizar um grupo de três alunos

Na nossa sala de

http://pt.wikipedia.org/wiki/Bullying

ittp://ww. bullying.com.br/BConceituacao21.htm

ttp://portaldoprofessor.mec.gov.br/fichaTecnicaAula.html?aula=858 
Aqui você encontrará informaçōes importantes para erradicar o MAL (bullying).

Texto para os alunos:

Estāo sabendo agora do que se trata? Então, farăo o texto argumentativo sobre o assunto. Bateu a dúvida de como produzir um texto argumentativo? vamos rever em sala de ula como organizar o texto argumentativo.

Agora que estão bem espertos com o que é o bullying, vocês irão assistir alguns slides sobre isso, aprofundando-se no assunto para informar aos pequenos de nossa escola

como agir ou reagir quando perceber o bullying.Os videos estâo em:

http://www.youtube.com/watch?v=6zavsKs2VDU

http://www. mundorecord.com.br/play//1de33830-5e6d-4180-b1e0-5e8492cebd88

Depois procurarão imagens no Google para a apresentação feita para os pequenos. Que imagens constrangedoras, não acham?

Capriche, agora vocês serâo os professores. Escolham imagens para produzir um texto chamativo para a prevençāo de atitudes do MAL (bullying) em nossa escola.

http://images. google.com.br/images?hl=pt-BR\&q=bullying\&btn $G=$ Pesquisar+imagens\&gbv=2

Avaliação

Vocês serăo avaliados de acordo com :

-participação no grupo;

-apresentaçắo

-introduçăo:

-o processo para chegar até a apresentação do Debate Deliberativo, no pátio da escola.

Serão avaliados com os critérios abaixo sendo classificados como: Iniciante, Profissional ou Mestre no assunto.

Participaçăo no grupo

Comprometimento

Nāo colaborou com o grupo, deixando de cumprir sua parte na tarefa combinada.

Colaborou pouco com o grupo, cumprindo parcialmente sua tarefa

Com a tarefa proposta

Respeito às opiniōes

-Nẫo soube respeitar a opinião da equipe durante as discussões, impondo suas opiniōes o tempo todo.

-Esforçou-se por respeitar a opiniẫo do grupo, mas em alguns momentos teve dificuldades.

-Respeitou a opinião do grupo e soube colocar suas idéias de modo compreensivel, buscando resolver os desafios propostos.

Apresentação

-Clareza na apresentação (de acordo com a parte proposta para cada membro da equipe)

A apresentação não trouxe grandes contribuiçōes para entendimento do grupo relacionado a proposta de trabalho com WebQues

A presentaç̄o trouxe alguns elementos importantes, no entanto deixou muitas dúvidas.

A apresentaçăo sintetizou muito bem elementos importantes contribuindo para compreensāo da proposta pelos participantes da equipe.

No término das atividades os educandos deverão formar uma opinião sobre o assunto e verbalizá-las para o grupo, produzir textos-denúncia sobre o assunto e dar palestras nas outras turmas com a responsabilidade de alarmar e sensibilizar os estudantes dos efeitos nocivos do bullying.

www. nomorebullying.com.br

www.bullying.com.br

www. wikipédia.com.br

www.youtube.con

www.images.google.com. br

Ao final do desenvolvimento da webquest, os alunos terâo divulgado o tema tratado no blog da escola, onde postarão os resultados destas aulas e de outras possiveis.

Recursos Educacionais

NOME TIPO

Reflexo Animaçăo/simulaçăo

Recursos Complementares

Datashow para apresentação dos resultados encontrados pelos alunos para alunos;

Filmes relacionados ao tema, com discussâo das atitudes e consequências.

Filme indicado: Columbine.

Avaliaçäo

A avaliaçăo será feita de acordo com a produção, engajamento dos alunos no desenvolvimento e apresentação do resultado de pesquisa, sempre observando se o aluno será capaz de:

Demonstrar compreensāo de textos orais, nos gêneros previstos para as aulas, por meio de retomada de tópicos dos textos:

Atribuir sentido a textos orais e escritos, posicionando-se criticamente diante deles;
Selecionar procedimentos de leitura adequados a diferentes objetivos e interesses (estudo, formação pessoal, realização da tarefa) e as caracteristicas do gênero e suporte. 
BRASIL

VISUALIZAR AULA

As várias facetas de Machado de Assis

24/10/2008

Autor e Coautor(es)

Autor: Grace Luciana Pereira

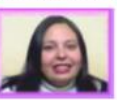

SAO PAULO - SP Universidade de São Paulo

Estrutura Curricular

MODALIDADE / NIVEL DE ENSINO

Ensino Fundamental Final

COMPONENTE CURRICULAR

TEMA

Dados da Aula

$\mathrm{O}$ que $\mathrm{o}$ aluno poderá aprender com esta aula

Conhecer vários contos de Machado de Assis; Comparar as histórias e seus entrelaces. Compartilhar histórias e opiniōes sobre a obra do autor estudado.

Duraçầo das atividades

5 aulas

Conhecimentos prévios trabalhados pelo professor com o aluno

O que eles sabem sobre a biografia de Machado de Assis e sua obra. A entonaçăo necessária para uma leitura coletiva.

Estratégias e recursos da aula

Disponibilize o recurso de video que apresenta a biografia de Machado de Assis. Sequência didática

13

Machado de Assis

Leia um trecho do seu livro favorito de Machado de Assis e compartihe com os alunos o porquê dele ser seu preferido. Para seduzir os alunos é necessário que o professor tenha sido seduzido antes, portanto leia, estude, descubra o que mais the agrada na obra deste grande autor.

Retome o conceito de sarau e sua importância em várias épocas. Comente sobre o comportamento esperado neste tipo de atividade. Um escuta ativa e participativa. Segue duas sugestôes de sites com alguns contos, mas nada impede que o aluno traga um outro livro e assim ler um trecho e deixar todos intrigados pela continuidade da historia

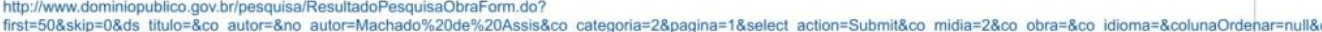
Oriente as duplas a explicarem o porquê escolheram o trecho ou conto. Destaque em cada leitura as caracteristicas da obra de Machado de Assis. Proponha a criaçăo de uma Academia Brasileira de Letras Mirim na escola, onde cada aluno pode se aprofundar em um escritor e se apresentar nos saraus. Prepare a

Recursos Educacionais

NOME TIPO

Machado de Assis Video

Recursos Complementares

http://www2.uol.com. br/machadodeassis/ http://www.mundosites.nettiteratura/machadodeassis.htm http://www.machadodeassis.net/ http://www.biblio.com.br/defaultz.asp?

link=http://www.biblio.com. br/conteudo/MachadodeAssis/MachadodeAssis. htm http://www.dominiopublico.gov.br/pesquisa/ResultadoPesquisaObraForm.do?

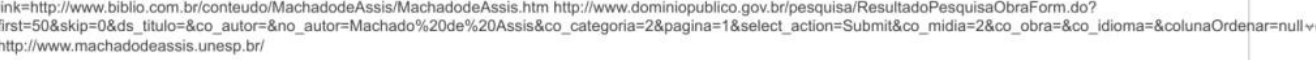
Avaliaçăo 
$8 / 22 / 2017$

Portal do Professor - Lições de língua crítica e culta

BRASIL

Serviços Barra GovBr

VISUALIZAR AULA

Lições de língua crítica e culta

10/09/2009

Autor e Coautor(es)

Autor: Taciana Raquel Fiorentin Calza

imagem do usuário

RONDINHA - RS CENTRO ESTADUAL DE EDUCACAO BASICA CONDE D EU

Estrutura Curricular

MODALIDADE / NIVEL DE ENSINO

Educaçãa de Jovens e Adultos - $2^{\circ}$ ciclo

Ensino Fundamental Final

COMPONENTE CURRICULAR

Ensino Médio

Lingua Portuguesa

Lingua Portuguesa

TEMA

Lingua Portuguesa

Linguagem escrita: leitura e produção de textos

Lingua oral e escrita: prática de produçāo de textos orais e escritos

Produção, leitura, análise e reflexão sobre linguagens

Dados da Aula

○ que o aluno poderá aprender com esta aula

- Interpretar diferentes tipos de textos;

- Interagir e redigir;

Duração das atividades

7 aulas

Conhecimentos prévios trabalhados pelo professor com o aluno

- Habilidade básica de leitura:

- Interpretaçăo e redação

Estratégias e recursos da aula

As estratégias utilizadas nessa aula serão:

- Uso de multimidias da Internet;

- Material de Uso Diário;

- Trabalhos em grupos;

- Trabalhos indivivi
ATIVIDADE I-

ATIVIDADE I-

Esta aula terá como primeira atividade a leitura (oral, visual e auditiva) da letra da música Cidadáo de Zé Ramalho:

diferentes videos).

A leitura poderá ser feita individualmente ou dependendo do tamanho da turma e número de computadores poderá ser desenvolvida em duplas, trios...

Em seguida divida os alunos em grupos para que, após a leitura, façam a dramatizaçāo da letra da música.

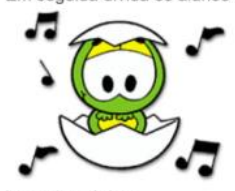

Letra da música:

Cidadāo - Zé Ramalho ( http://zeramalho.musicas.mus.br/letras/75861/ )

Tá vendo aquele edificio moço

Ajudei a levantar

Foi um tempo de afliçẫo

Eram quatro conduçăo

Duas prá ir, duas prá volt

Olho pra cima e fico tonto

Mas me vem um cidadão

E me diz desconfiado

"Tu tá ai admirado?

Ou tá querendo roubar?"

Meu domingo tá perdido

Vou prá casa entristecido

Dả vontade de beber

E prá aumentar meu tédio
Eu nem posso olhar pro prédio
Que eu ajudei a fazer...

Tá vendo aquele colégio moço
Eu também trabalhei lá

Lá eu quase me arrebento

Fiz a massa, pus cimento

Ajudei a rebocar

Minha filha inocente
Vem prá mim toda contente

Pai vou me matricular

"Criança de pé no chẫo

http://portaldoprofessor.mec.gov.br/fichaTecnicaAula.html?aula=5270 
8/22/2017

Aqui nao pode estudar

Tser

Por que é que eu deixei o norte

Eu me pus a me dizer

Mas o pouco que eu plantava

tá vendo aquela igreja

Onde o padre diz amém

Pus o sino e o badalo

Enchi minha mâo de calo

Lá eu trabalhei também

Tem quermesse, tem novena
Eo padre me deixa entrar

Foi láa que Cristo me edisse

"Rapaz deixe de tolice

Não se deixe amedrontar

Fui eu quem criou a terra

Enchi o rio, fiz a serra

Não deixei nada faltar

Hoje o homem criou asa

Eu naioria das casas

Fui euterm náo posso en

Enchi o rio, fiz a serra

Não deixei nada faltar

Hoje o homem criou asas

Ena maioria das casas

Eu também năo posso entrar"

Hièl Hiè! Hiè! Hiè!

Hiél On! Oh! Oh!

ATMADEl

os alunos para que acessem os endereços eletrônicos abaixo e assistam aos videos publicados no youtube sobre a música: Cidadão de Zé Ramalho disponiveis
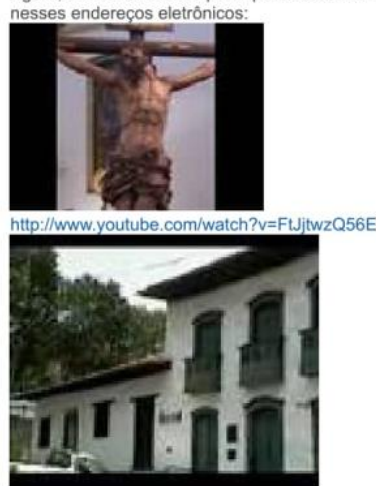

http://www.you

ATIVIDADE III -

Após eles assistirem aos vídeos reúna- os em duplas e oriente-os para que façam uma reflexăo com o(a) colega de turma. Oriente-os para que discutam sobre o conteúdo das magens dos vídeos e o conteúdo da letra da música.

Na sequência o professor fará questionamentos aos alunos para que refiltam sobre o que leram e o que assistiram.

Em seguida estâo algumas sugestōes de questionamentos. Você está livre para criar outros, conforme a situação, ou conforme a turma: As imagens condizem com a letra da música? A letra da música possui conteúdo real ou imaginário? A linguagem presente no texto é uma linguagem figurada? Por quê? Quem sâo as pessoas que realizam o

trabalho de construçăo? Por que, mesmo conhecendo a obra, tendo ajudado a construi-la essas pessoas ficam do lado de fora e sắo vistas como ladrōes, pelos cidadãos comuns, ao admirá-la? Você concorda com a indignaçẩo presente, principalmente no segundo video (http://Www.youtube.com/watch?v=SJclizeiMd_w\&feature=related)? Por conteúdo da música como uma atitude de exclusão social? Por quê??

ATIVIDADE IV

Como pode ser observado, há várias passagens no texto/música da utilização de linguagem coloquial.

Sugira aos alunos que re Desafie-os a cantarem oralmente, em grupos, a música reescrita de acordo com a norma culta da Língua Portuguesa.

Questione os alunos se eles conhecem outras músicas que sāo compostas utilizando a linguagem coloquaial?

ATIVIDADE V

Depois de conversarem, no grande grupo, sobre os possiveis exemplos que deverão surgir, apresente-lhes o video abaixo. Aceite as sugestōes de seus alunos para que se sintam valorizados e desafiados a pesquisar e aprender cada vez mais.

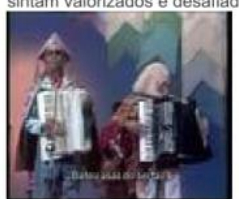

http://www.youtube. com/watch?v=bSzoMX2GPq

Assistam ao video e em seguida, observando a letra da música abaixo, oriente-os para que, individualmente, transcrevam-na para a norma culta da Língua Portuguesa. Em seguida façam comparaçōes oralmente.

Letras da música:

Asa Branca - Gonzaguinh

Composição: Luiz Gonzaga / Humberto Teixeira

1-Quando oiei a terra ardendo

Cu a fogueira de Sáo Joáo

Por que tamanha judiaçāo(2x)

2-Que braseiro, que fornaia

Nem um pé de prantaçăo

Por falta d'água perdi meu gado

http://portaldoprofessor.mec.gov.br/fichaTecnicaAula.html?aula=5270 
$8 / 22 / 2017$

3-Inté mesmo a asa branca

Bateu asas do sertăo

Entonce eu disse adeus Rosinh

Guarda contigo meu coraçăo(2x)

4-Hoje longe muitas

Espero a chuva cair de novo

Para mim vorta pro meu sertāoo $(2 x)$

5-Quando o verde dos teus olhos

Se espalhar na prantação

Eu te asseguro não chore não, viu

Que eu voltarei, viu

(http://letras.terra.com.br/gonzaguinha/490928/)

ATIVIDADE VI-

Ainda no Laboratório de Informática, questione os alunos sobre o que é uma boa redaçấo?

Deixe uns minutos para que discutam em duplas. Depois, oralmente, as duplas deverão expor ao grupo, o resultado de sua discussẫo.

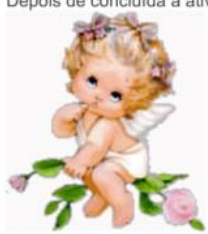

http://www.portrasdasletras.com.b r/pdti2/sub.php?op=corrigir/docs/cap 6

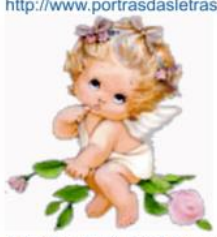

ttp://www. universia.com.br/materia/materia.jsp?materia $=14581$ Professor, o objetivo destas atividades listadas acima é o de oportunizar aos estudantes o contato com outros tipos de textos (música), a consulta a opiniōes de outros
professores e profissionais da educą̧ăo sobre a escrita da redaçāo. É necessário que depois das consultas realizadas pelos alunos sobre as caracteristicas de uma boa redaçăo eles sejam instigados a sintetizá-las, individualmente, para posterior elaboraçâo de uma redaçẫo. Cada aluno deve criar um guia, uma espécie de lista fundamental para guiar a realização de
ATIVIDADE VII -

Professor, depois de pesquisar, e elaborar uma listar de pontos necessários para a elaboraçăo de uma redaçăo, sugere-se que os alunos sejam distribuidos em forma de circulo à fim de que cada um exponha o que considera mais importante na sua lista/esquema.

Você, professor, poder

Agora cada estudante criará sua própria redação abordando o tema: exclusão social - causas e consequências e observando todos os pré-requisitos tratados nas atividades cores, principalmente a utilizaçẫo da norma culta da Lingua Portuguesa.

\section{Recursos Complementares}

hitp: //www.tudosobreredacao blogspotcom/

http://www.soportugues.com.br!

\section{Avaliação}

A avaliaçăo se dará de forma coletiva em todos os momentos em que os alunos estiverem participando das discussōes propostas e individualmente por meio da produçăo das atividades escritas ou quando solicitada a exposiçăo individual de um posicionamento.

A segunda etapa da avaliação se dará pela leitura (feita pelo professor) dos textos produzidos pelos alunos, conforme critérios adotados para a correção das redaçōes: em insuficiente: se o texto do aluno nâo estiver de acordo com aquilo que foi visto nas atividades propostas; satisfatoria: se o texto produzido estiver de acordo com o que foi trabalhado, porém não tenha usado argumentos bem estruturados e mais que satisfatória: se o texto produzido estiver de acordo com a norma culta da lingua, tiver seguido todos os passos de elaboraçăo de uma boa redaçāo, tiver argumentos bem elaborados.

mediar liçōes de língua critica e culta.

Professora Taciana 